\title{
Estudo citogenético e evolutivo em espécies brasileiras de Eleocharis (Cyperaceae)
}

Tese apresentada ao curso de pós-graduação em Genética para obtenção do Título de Doutor em Genética, da Universidade Estadual Paulista

Orientador: Prof. Dr. André Luis Laforga Vanzela

\section{0}

Carlos Roberto Maximiano da Silva 


\section{Estudo citogenético e evolutivo em espécies brasileiras de Eleocharis (Cyperaceae).}

Tese apresentada ao curso de pós-graduação em Genética para obtenção do Título de Doutor em Genética, da Universidade Estadual Paulista

\section{Comissão examinadora}

Prof. Dr. ANDRÉ LUIZ L VANZFLA(Orientador)

Prof. Dr. CESAR MATINS

Profa. Dra. DORALICE MARIA CELLA

Prof. Dr. MARCELO DOS SANTOS G FILHO

Profa. Dra MARIA TERCILIA VDE AZEREDOOLIVEIRA

2010

Carlos Roberto Maximiano da Silva 


\section{Agradecimentos}

Aos meus pais, Paulo Roberto M. da Silva e Anna Maria dos Santos da Silva, a minha avó Janir Pererira dos Santos e meu avô José Messias dos Santos por sempre me apoiarem.

A minha noiva Renata da Rosa, em especial, por tornar meus sonhos realidades.

Ao meu amigo André L. L. Vanzela.

Ao meu grande irmão (literalmente), Fernando Roberto M. da Silva.

A todos os professores que me ajudaram em especial a Profa. Claudia Regina Bonini Domingos e a Profa. Maria Tercília Vilela de Azeredo Oliveira.

A todos do LABRE, pelo auxilio e pelo agradável ambiente de trabalho.

A CNPq, pelo auxilio financeiro.

A todos que de algum modo contribuíram para a realização deste trabalho. 
Dedico este trabalho a minha Família em especial ao meu avô: José Messias dos Santos. 


\section{Resumo}

A família Cyperaceae é a terceira maior entre as monocotiledôneas, com 42 gêneros encontrados no Brasil. Eleocharis é o quarto gênero mais diverso, com 69 espécies encontradas em áreas alagadas, margens de rios e lagos. São plantas com morfologia simples, porém, com uma grande variação morfológica. Isto tem dificultado a identificação e organização taxonômica deste grupo. Este gênero, assim como toda a família, também é conhecido por possuir cromossomos holocêntricos, meiose pósreducional e formação de pseudomônades, além de uma grande variação intra- e interespecífica no número cromossômico. Buscando compreender a evolução cariotípica e esclarecer problemas taxonômicos neste grupo, foram estudadas 259 amostras de 10 estados brasileiros, representando cerca de $40 \%$ das espécies. Análises citogenéticas revelaram variação cromossômica interespecífica de $2 n=6$ (E. subarticulata e E. maculosa) até $2 n=60$ (E. laeviglumis), causada principalmente por poliploidia. Apesar desta variação, o número básico $x=5$ é sugerido. As maiores variações intraespecíficas foram encontradas em $E$. maculosa $(2 n=10,8,7$ e 6) decorrente de simploidia e no complexo de espécies formado por E. viridans e E. niederleinii, nas quais os dados citogenéticos e moleculares indicam uma origem híbrida associada à fissão e/ou fusão cromossômicas e poliploidia. A localização física dos sítios de DNAr 45S e 5S por FISH mostrou sinais de 45S sempre terminais e com múltiplos sítios (2 a 10). Esta multiplicação de sítios pode ser resultado de amplificação seguido de dispersão pelas pontas dos cromossomos com mesmo tamanho. O sítio de DNAr $5 \mathrm{~S}$ foi menos variável em número ( 2 a 4) por cariótipos, contudo, variou entre as posições terminais e intersticiais. Este estudo mostra que os mecanismos responsáveis pela diversidade cariotípica em Eleocharis são próximos àqueles reportados para o gênero Rhynchospora e Carex, com diferenças na predominância de agmatoploidia e simploidia em Carex e poliploidia nos demais grupos. Em termos taxonômicos, este estudo reforçou ainda mais a grande diversidade dentro do subgênero Eleocharis, bem como a separação de Limnochloa dos demais subgêneros, como proposto em estudos de filogenia molecular.

Palavras chave: Citotaxonomia, Cromossomos holocêntricos, Poliploidia, Rearranjo cromossômico 


\section{Sumário}

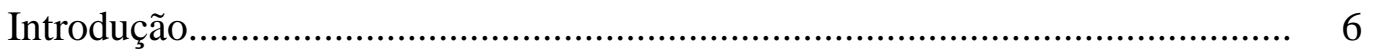

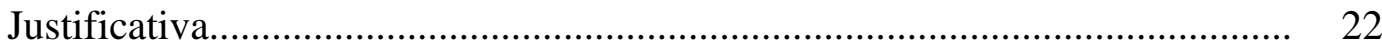

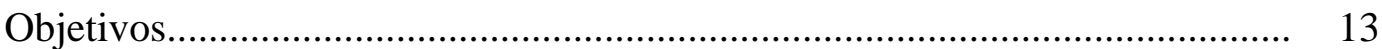

Referências da Introdução.............................................. 24

\section{Capítulo 1}

Karyotypic diversification and its contribution to the taxonomy of Eleocharis (Cyperaceae) from Brazil.....................................................

\section{Capítulo 2}

Cytogenetical and cytotaxonomical analysis of some Brazilian species of Eleocharis (Cyperaceae).............................................. 50

\section{Capítulo 3}

Distribution of $45 \mathrm{~S}$ and $5 \mathrm{~S}$ rDNA sites in 23 species of Eleocharis (Cyperaceae)

\section{Capítulo 4}

Chromosome reduction in Eleocharis maculosa (Cyperaceae).

\section{Capítulo 5}

Análises citogenéticas e moleculares revelam um complexo de híbridos e poliploides em Eleocharis série Tenuissimae (Cyperaceae). 


\section{Introdução}

\subsection{Família Cyperaceae}

Cyperaceae Juss. é a terceira maior família das monocotiledôneas e apresenta distribuição cosmopolita. Seus representantes ocorrem em uma variedade de habitats, sendo mais frequentes em áreas úmidas como brejos, pântanos, margens de rios, charcos e ambientes de restinga (Dahlgren et al. 1985, Goetghebeur 1998 e Judd et al. 1999).

Esta família possui mais de 5.500 espécies, distribuídas em mais de 109 gêneros (Govaerts et al. 2007). O primeiro levantamento da flora de Cyperaceae realizado para todo o Brasil registrou cerca de 300 espécies em 65 gêneros (Ness 1842). Recentemente, foram identificadas 678 espécies em 42 gêneros, sendo que os de maior riqueza de espécies são Rhynchospora Vahl (157espécies), Cyperus L. (101espécies), Scleria Berg. (82 espécies) e Eleocharis R. Br., com 69 espécies (Alves et al. 2009). Algumas imagens de representantes desses grupos são apresentadas na Figura 1.
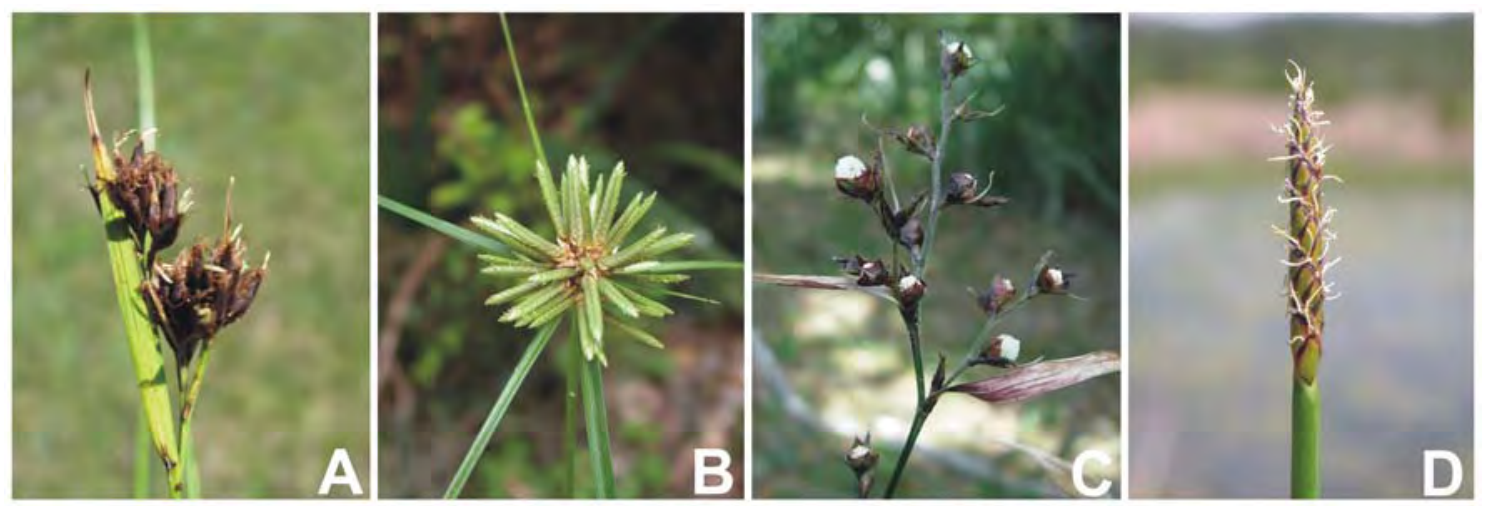

Figura 1. Diversidade da inflorescência das espécies de Cyperaceae dos quatro gêneros mais abundantes no Brasil. A) Rhynchospora polyantha Steud.; B) Cyperus incomtus Kunth; C) Scleria panicoides Kunth e D) Eleocharis laeviglumis R. Trevisan \& Boldrini 
Estudos filogenéticos, realizados por Muasya et al. (2000), sugerem que esta família compreende um grupo monofilético, próximo de Juncaceae. No entanto, a determinação das relações taxonômicas em Cyperaceae pode ser considerada difícil, devido ao tamanho reduzido das flores e às inflorescências condensadas. Segundo o estudo taxonômico realizado por Bruhl (1995), a família é dividida em duas subfamílias (Cyperoideae e Caricoideae) compostas por 14 tribos. Goetghebeur (1998) concordou com as 14 tribos, no entanto, este autor dividiu a família em quatro subfamílias (Cyperoideae, Caricoideae, Scleroioideae e Mapanoideae). Com o auxílio de dados moleculares, Simpson et al. (2003, 2007) e Muasya et al. (2009) dividiram a família Cyperaceae em duas subfamílias: Cyperoideae e Mapanoideae, composta pelas mesmas 14 tribos. Apesar das diferentes classificações, o gênero Eleocharis foi sempre incluído à tribo Eleocharidae, subfamília Cyperoideae.

\subsection{Características morfológicas do gênero Eleocharis}

Eleocharis possui aproximadamente 250 espécies, das quais 16 são endêmicas do Brasil (Alves et al. 2009). Apesar de ser um gênero cosmopolita, a maioria das espécies está nas regiões tropicais e subtropicais das Américas (Govaerts et al. 2007). São encontradas em solos que ficam temporariamente úmidos ou inundados, e algumas espécies vivem total ou parcialmente submersas (Trevisan e Boldrini 2008). Segundo Svenson (1929), Eleocharis é um gênero natural que fazia parte do gênero Scirpus L.. Atualmente, Eleocharis encontra-se separado de Scirpus devido à ocorrência de inflorescência única sem brácteas involucrais e estilopódio persistente, endurecido, dilatado e articulado com o ovário. Scirpus, de acordo com Goetghebeur (1998), possui inflorescência composta com brácteas involucrais, estilopódio pouco nítido e não espessado. 
As espécies do gênero Eleocharis possuem: colmo fotossintetizante com bainhas na base, glumas geralmente imbricadas e espiraladas ao longo do eixo da espigueta, flores bissexuais, perigônio reduzido a cerdas ou ausente, estames geralmente trífidos e estilete 2-3-fido (Svenson 1929 e González-Elizondo 1994). Segundo Svenson (1929, 1932, 1934, 1937 e 1939), as espécies podem ter hábitos cespitoso, rizomatoso ou estolonífero. Contudo, Trevisan e Boldrini (2008) organizaram as espécies brasileiras em cespitosas com e sem formação de cáudice; cespitosas-estoloníferas com estolhos de entrenós longos; cespitosas-rizomatosas com rizomas curtos e cespitosas-rizomatosas com rizomas alongados de entrenós curtos. A Figura 2 mostra os esquemas com os hábitos propostos por estes autores.

Os caules das ciperáceas, também chamados de colmos, são geralmente sólidos, frequentemente 3angulado, podendo ser ramificados ou não (Mohlenbrock 1976). Em Eleocharis, o colmo é um escapo, o qual em secção transversal pode apresentar três ou mais ângulos, ou ainda ser redondo a elíptico, e com função fotossintetizante (Ueno et al. 1989). Cada colmo ereto que sai do rizoma de Eleocharis é um ramo terminal que possui duas bainhas. Uma inferior que é frouxa, membranácea e mais fendida,

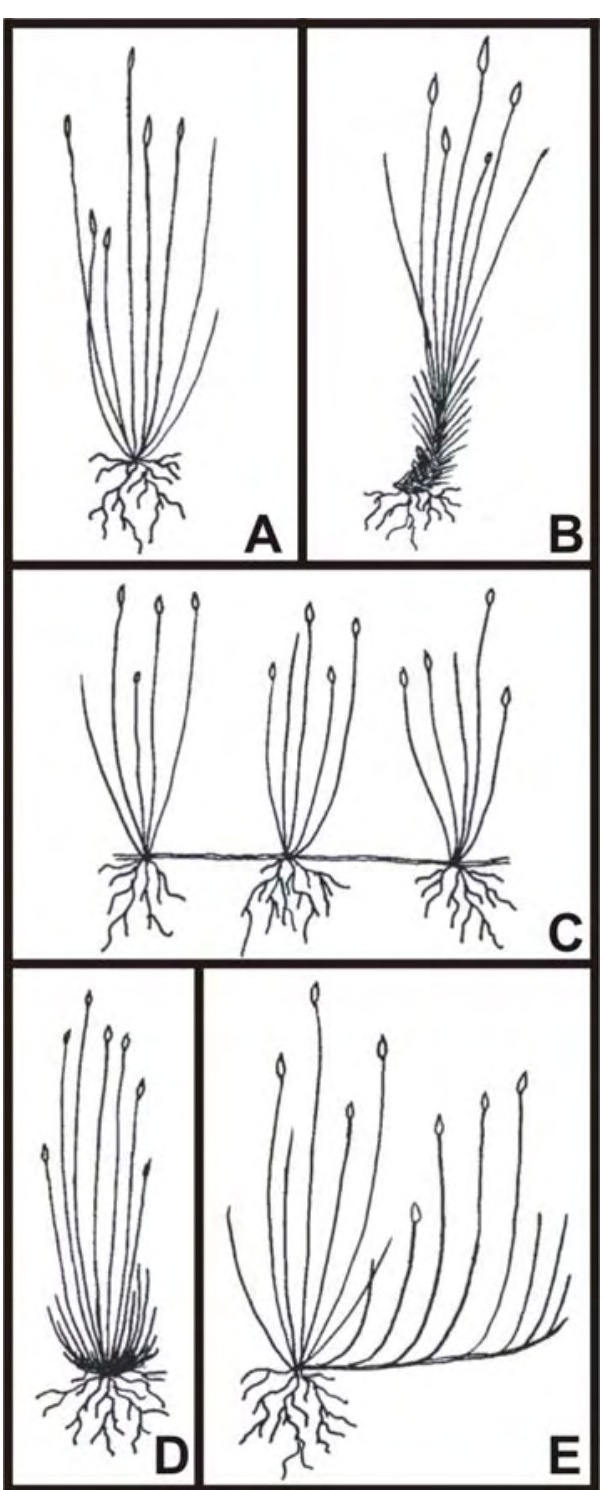

Figura 2. Esquema mostrando os hábitos em Eleocharis. A) Cespitoso; B) Cespitoso, com formação de cáudice; C) Cespitoso- estolonífero, com estolhos de entrenós longos; D) Cespitosorizomatoso com rizomas curtos e E) Cespitoso-rizomatoso com rizomas alongados de entrenós curtos. Fonte: Trevisan e Boldrini (2008). enquanto que a superior é cilíndrica e envolve o 
colmo (veja a Figura 3). Esta última estrutura tem valor taxonômico, sobretudo o ápice. A presença ou ausência de múcron dorsal, o ápice truncado ou oblíquo, o apêndice hialino, rugoso ou não, são alguns dos principais caracteres diagnósticos das bainhas.

As inflorescências das Cyperaceae são compostas por uma ou mais brácteas involucrais. Eleocharis, no entanto, não possuem esses invólucros, sendo isto uma das características que definem o gênero. As inflorescências são as mais simplificadas dentro da família, aparecendo como

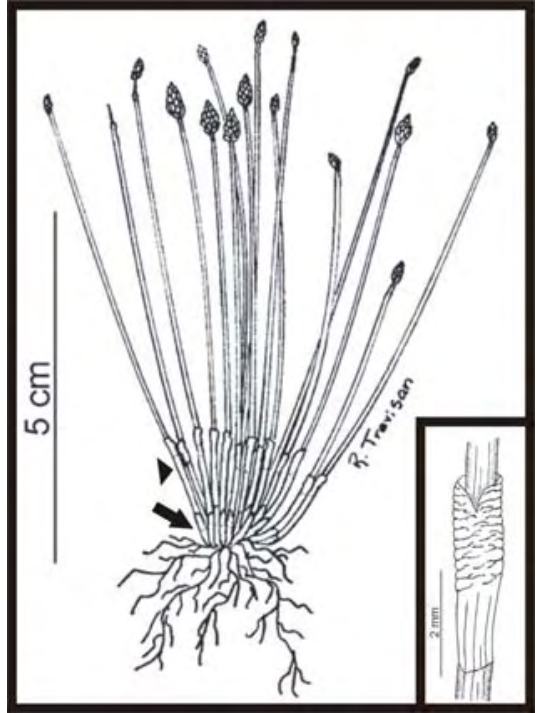

Figura 3: Desenho de E. flavescens. A seta aponta para a bainha inferior. A cabeça de seta aponta para a bainha superior. Em maior aumento, o detalhe do ápice hialino rugoso hialino da bainha superior. Fonte: Trevisan e Boldrini (2008). espigueta única no ápice do colmo (veja a Figura 4). A polinização é anemófila, como na maioria das Cyperaceae. As espécies apresentam redução das características de atração a visitantes. Por outro lado, produzem grande quantidade de grãos de pólen.

O número de estames em plantas anemófilas é geralmente grande, e as anteras encontram-se frequentemente expostas, elevadas para fora da flor por filetes longos e flexíveis, com pedicelo móvel. O estigma é geralmente plumoso e grande, ficando exposto para aumentar a probabilidade de contato com os grãos de pólen. Os aquênios apresentam as características morfológicas mais significativas na diferenciação das espécies de Eleocharis (Svenson 1929, 1939 e González-Elizondo e Peterson 1997). As mais importantes são a forma e a coloração da base do estilete, bem como o tamanho e o número de cerdas periânticas. Neste gênero, assim como em toda a família, algumas espécies possuem aquênios com superfícies lisas e outras com superfície ornamentada (Trevisan e Boldrini 2008) (veja a Figura 5). Contudo, quando observados ao 
microscópio eletrônico de varredura, todos os aquênios apresentam ornamentação com

valor taxonômico (Menapace 1990 e Lye 2000) (veja a Figura 6).
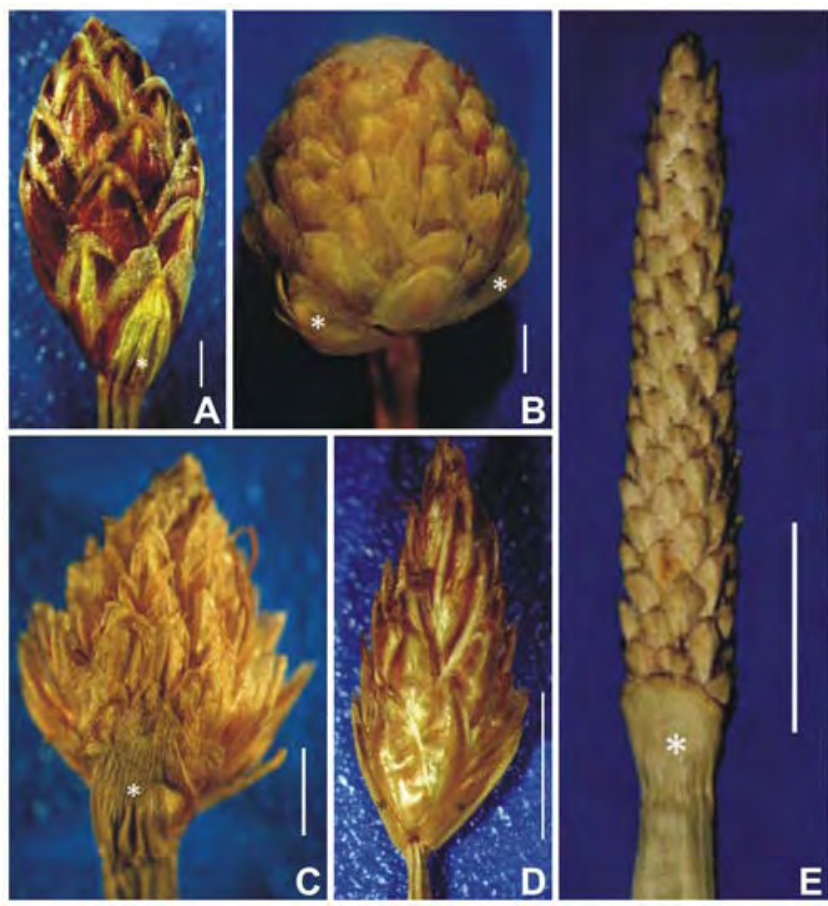

Figura 4. Diferentes formas de espiguetas em Eleocharis. A) Elipsóide em E. maculosa. B) Globosa de E. geniculata. C) Obovóide de E. pachystyla. D) Elipsóide de E. sellowiana. A-D) Barra = 1mm. E) Cilíndrica em E. interstincta. Barra $=10 \mathrm{~mm}$. Os asteriscos indicam as basais. Fonte: Gil e Bove (2007)

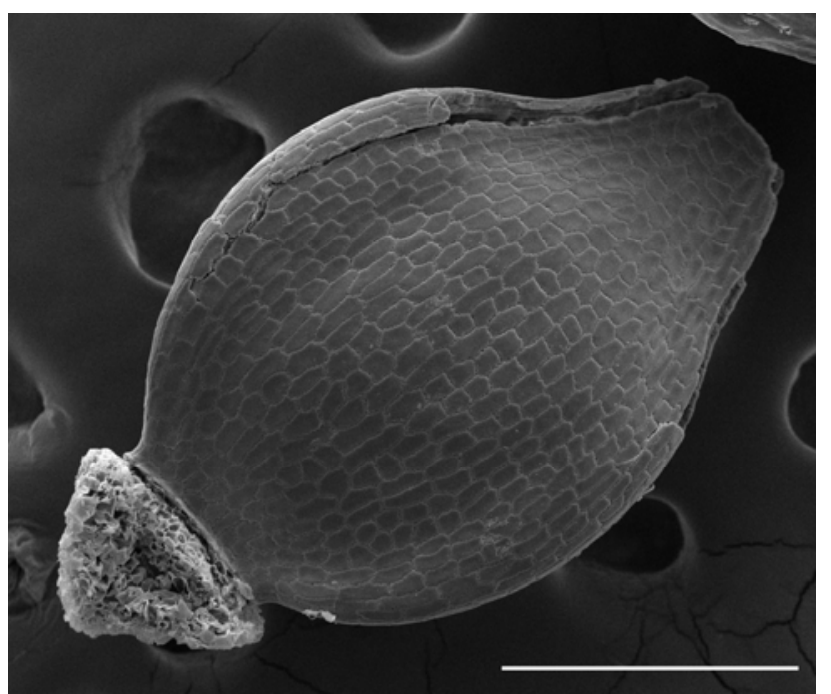

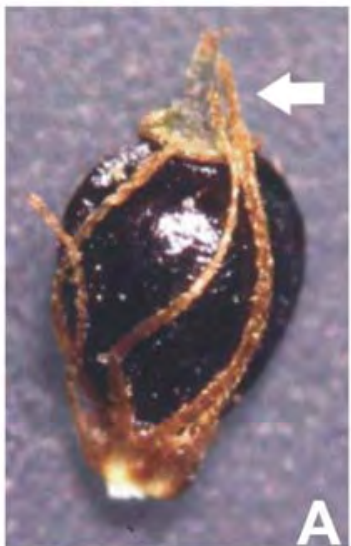
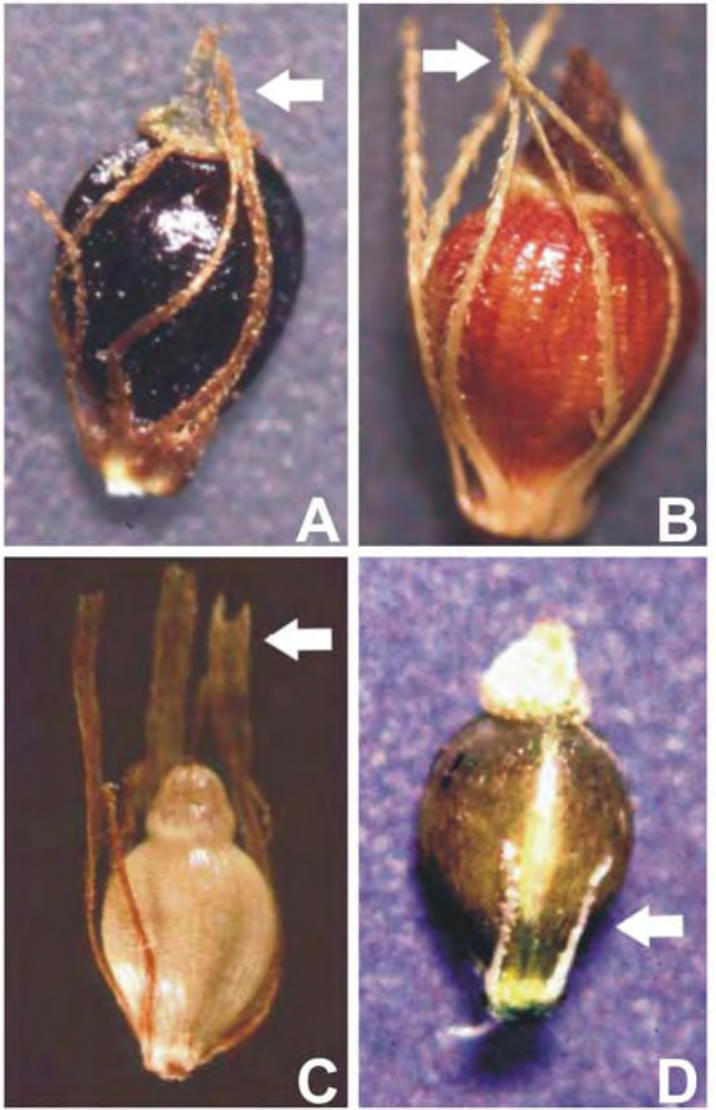

Figura 5: Aquênios de Eleocharis. A) Com superfície lisa em E. debilis. A seta aponta a cerda periântica com o mesmo tamanho do corpo do aquênio. B) Com superfície ornamentada em $E$. interstincta. A seta aponta a cerda periântica maior que o comprimento do corpo do aquênio. C) com superfície ornamentada em E. mutata. A seta aponta a cerda periântica muito maior que o corpo do aquênio. D) Com superfície lisa de $E$. minima. A seta aponta a cerda periântica menor que o comprimento do aquênio. Observe ainda as diferentes formas e cores dos frutos.

Figura 6: Aquênio de Eleocharis minima em microscopia eletrônica de varredura, mostrando ornamentação em sua superfície. Barra $=300 \mu \mathrm{m}$ 


\subsection{Relações taxonômicas e filogenéticas do gênero Eleocharis}

Eleocharis é um grupo marcado por morfologia simples, mas com grande variação intraespecífica (Simpson 1988). Isto tem proporcionado problemas de identificação e classificação das espécies no gênero. Prova disso é que na literatura são encontrados mais de 600 nomes de espécies. Contudo, atualmente, são reconhecidas pouco mais de 250 espécies (Svenson 1939, González-Elizondo e Peterson 1997 e Govaerts et al. 2007). Torrey (1836) organizou o gênero Eleocharis em 7 subgêneros, considerando as espécies da América do Norte. Koyama (1961) moveu E. margaritaceae e E. parvula do gênero Scirpus para Eleocharis e criou a seção Pauciflorae em Eleocharis. Kunth (1937), baseado no trabalho de Nees (1834, 1835), dividiu o gênero em três grupos sem hierarquia definida: Eleocharis Eleocharis (incluindo Eleocharis, Chaetocyperus Nees e Scirpidium Nees), E. Eleogenus e E. Limnocharis Kunth.

Com o passar do tempo, várias espécies de Eleocharis foram descobertas e novas classificações deste gênero foram elaboradas e modificadas. Uma das mais completas foi feita por Svenson (1929, 1934, 1937 e 1939), que organizou o gênero em nove séries. Kukkonen (1990) propôs a organização de Eleocharis nos subgêneros: Eleogenus (Nees) C.B. Clarke, Zinserlingia T.V. Egorova, Scirpidium (Nees) Kukkonen, Limnochloa (P. Beauv. ex T. Lestib.) Torr. e Eleocharis R.Br. A revisão mais recente e mais aceita foi feita por González-Elizondo e Peterson (1997). Estes autores dividiram o gênero nos subgêneros Scirpidium, Limnochloa, Zinserlingia e Eleocharis, seis seções, oito séries e sete subséries (Tabela 1). 
Tabela 1. Comparação entre as classificações para o gênero Eleocharis. Fonte: Yano et al. (2004)

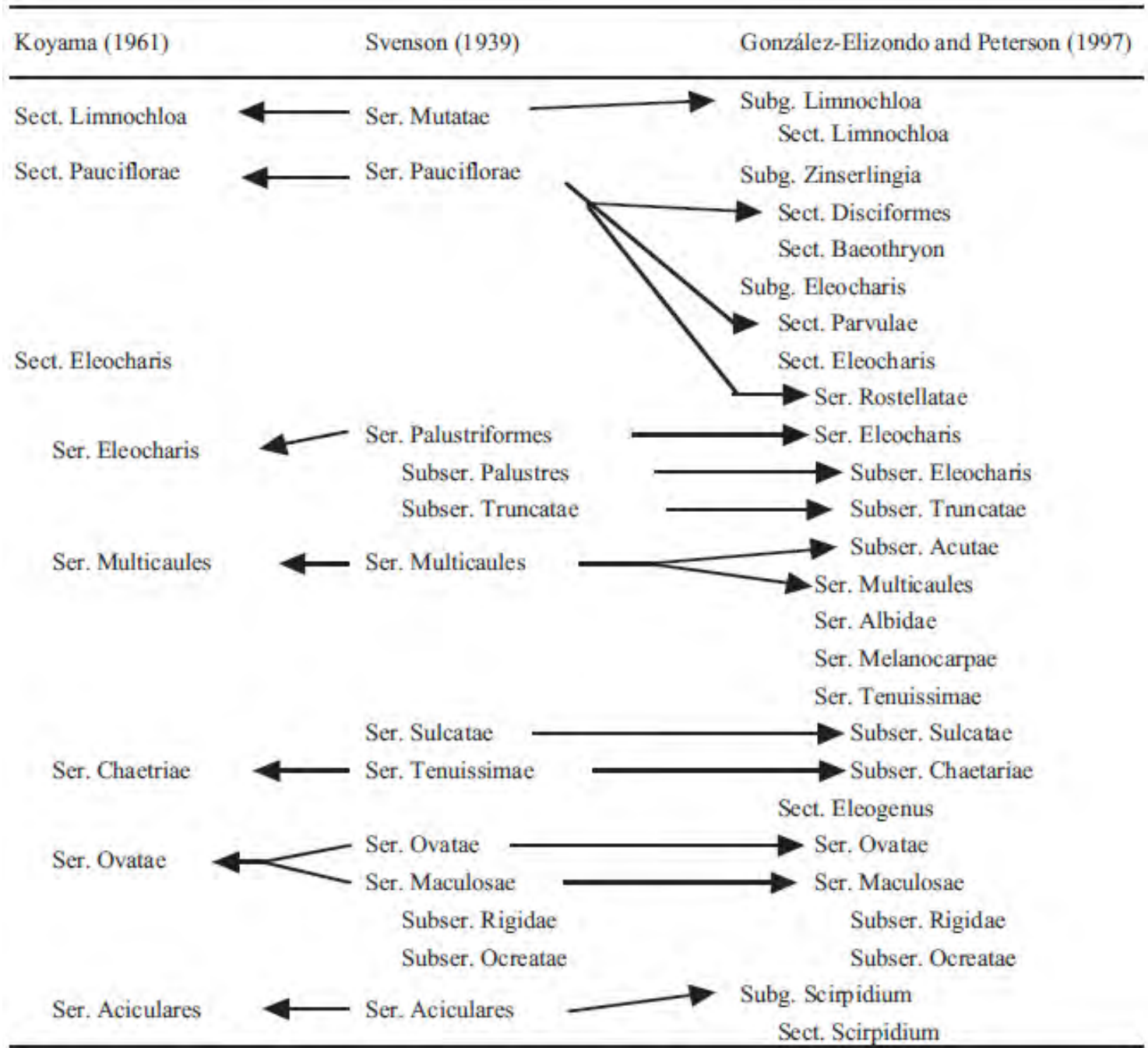

Tanto a classificação de Svenson (1939), quanto as demais classificações como as de Koyama (1961), Kukkonen (1990) e González-Elizondo e Peterson (1997), levaram em consideração apenas caracteres ligados a macromorfologia, como forma dos aquênios e relação da largura entre a espigueta e o colmo. Porém, trabalhos que fizeram a comparação destas classificações com dados moleculares, obtida pelo sequenciamento do "Internal Transcribed Spacer" (ITS) do rDNA, revelaram que não há correspondência total entre as classificações e as relações filogenéticas do grupo (Roalson e Friar 2000 e Yano et al. 2004). Os primeiros autores analisaram 38 espécies coletadas na América do Norte e compararam com as classificações Svenson (1939), Kukkonen (1990) e González-Elizondo \& Peterson (1997). Uma das maiores 
contradições envolveu o gênero Websteria S.H. Wrigth, o qual foi tratado como independente por alguns autores (González-Elizondo e Peterson 1997). Porém, este gênero ficou inserido no mesmo clado de Eleocharis. Além disso, este estudo suportou a idéia da monofilia nos subgêneros Limnochloa e Zinserlingia (sensu GonzálezElizondo \& Peterson 1997) e séries parafiléticas ou polifiléticas no subgênero Eleocharis.

O estudo de Yano et al. (2004) foi feito com 24 espécies japonesas de Eleocharis, comparando as classificações propostas por Koyama (1961), Svenson (1939) e González-Elizondo \& Peterson (1997). Os dados obtidos indicaram que a espessura da espigueta em relação à espessura do colmo é uma característica mais importante para a taxonomia do que as características encontradas no aquênio. As análises também confirmaram o que foi observado por Roalson e Friar (2000), já que os subgêneros Limnochloa e Zinserlingia (sensu González-Elizondo e Peterson 1997) apareceram como monofiléticos. Além disso, muitas subdivisões do subgênero Eleocharis apareceram como parafiléticas ou polifiléticas, como por exemplo, a série Tenuissimae.

Em um estudo mais recente, as análises moleculares do nrDNA ITS e cpDNA das sequências trnC-ycf6 e ycf6-psbM foram realizadas em 259 amostras de 154 espécies coletadas em todo mundo (Roalson et al. in press). Estes dados foram comparados com a classificação mais aceita (González-Elizondo \& Peterson 1997). Dentre os quatro subgêneros, os principais contrastes entre as análises filogenéticas e a classificação taxonômica apareceram no subgênero Eleocharis, principalmente nas séries Tenuissimae e Eleocharis. Para os subgêneros Scirpidium, Zinserlingia e Limnochloa, com exceção de algumas espécies como E. dulcis (subg. Limnochloa) e E. 
acicularis e E. bonariensis (subg. Scirpidium) que foram paraliléticas, os três subgêneros como um todo foram monofiléticos.

\subsection{Características citológicas de Cyperaceae e Eleocharis}

A família Cyperaceae possui três características citogenéticas conjuntas que são incomuns dentre os demais grupos de organismos: 1) cromossomos com centrômero difuso; 2) meiose pós-reducional e 3) formação de pseudomonades.

\subsubsection{Cromossomos holocêntricos}

Estes cromossomos não possuem constrição primária (Figura 7A) e o cinetócoro se organiza de modo difuso ao longo dos cromossomos, com exceção das regiões teloméricas, como demonstrado para Luzula nivea (Nagaki et al. 2005). Tais cromossomos foram descritos primeiramente em insetos (Scharader 1935), e somente em 1954 este tipo de cromossomo foi descrito no gênero Eleocharis, por Bataglia e Håkansson (veja Strandhede 1965). Além da família Cyperaceae, cromossomos holocêntricos foram descritos em representantes da família Juncaceae (Malheiros et al. 1947), apenas no gênero Drosera da família Droseraceae (Sheikh e Kondo 1995), em um subgênero de Cuscuta (Cuscutaceae) (Pazy e Plitmann 1994), em uma única espécie da família Liliaceae, Chionagraphis japonica Maxim. (Tanaka e Tanaka 1977) e em outra da família Myristicaceae, Myristica fragrans Houtt (Flach 1966). Além das plantas, cromossomos holocêntricos são encontrados em nematóides, como Caenorhabditis elegans Maupas (Buchwitz et al. 1999), em protozoários, algas e em várias ordens de insetos, incluindo Lepidoptera, Heteróptera e Odonata (Perez et al. 2000, Nokkala et al. 2002 e Wang e Porter 2004), e em espécies de alguns grupos de 
aracnídeos, como, Acari, Araneae e Scorpiones (Araujo et al. 2008 e Schneider et al. 2009).

$\mathrm{Na}$ literatura, são encontradas diferentes denominações para este tipo de cromossomo. Autores como Håkansson (1958), Hoshino (1987) e Vanzela et al. (1996) o denominam cromossomo holocêntrico, no entanto, há autores que denominam este cromossomo como policêntrico (Bernardini 1959). Apesar do nome holocêntrico ser erroneamente empregado, esta denominação é amplamente aceita e utilizada. O termo mais correto seria holocinético, pois não existe centrômero distribuído ao longo do cromossomo, mas sim, atividade cinética. Esta característica leva à migração paralela dos cromossomos na anáfase mitótica (Figura 7B), como já demonstrado por Harms (1968) e Guerra et al. (2006). Em alguns casos, são observadas constrições em alguns cromossomos. Estas são chamadas constrições nucleolares, que são relativas às constrições secundárias dos cromossomos monocêntricos (Westerman e Colle 1984, Vanzela et al. 2000 e Da Silva et al. 2008a).

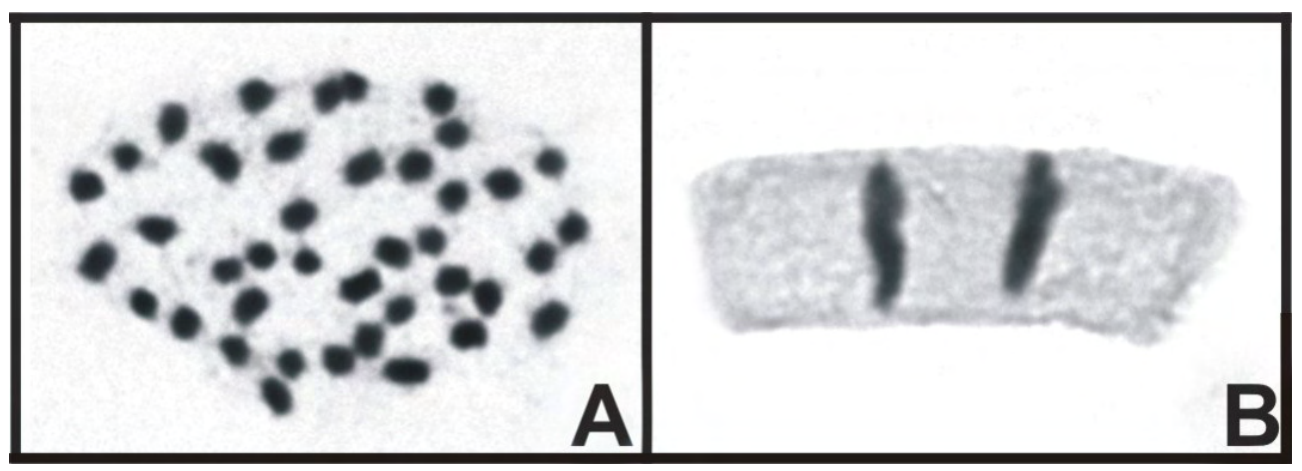

Figura 7. Cromossomos em coloração convencional com Giemsa A) Metáfase de Eleocharis montana $(2 n=40)$, uma espécies com cromossomos holocêntrico. Note que neste tipo de cromossomo não é possível observar constrições. B) Migração paralela dos cromossomos holocêntricos durante a anáfase da mitose em Eleocharis sellowiana ( $2 n=$ 20).

Cromossomos com cinetócoro difuso, quando natural ou artificialmente fragmentados e/ou fundidos, segregam normalmente na divisão celular, tanto na meiose quanto na mitose. Isto foi demonstrado por Castro et al. (1949), em Luzula purpurea (Juncaceae), por Håkansson (1954), em Eleocharis palustris (Cyperaceae) e em 
Rhynschospora pubera, por Vanzela e Colaço (2002). Esses processos de quebra e fusão cromossômica em holocêntricos recebem a denominação de agmatoploidia (quebra) e simploidia (fusão), respectivamente (Luceño e Guerra 1997). Muito embora alguns trabalhos citem agmatoploidia tanto para quebra como para fusão cromossômica, em holocêntricos (Roalson 2008).

A permanência de cromossomos originados por fusão e fissão contribui para a extensa variação inter e intra-específica no número cromossômico em Cyperaceae, mesmo que poucas espécies tiveram seus números cromossômicos descritos. De cerca de 5.500 espécies de Cyperaceae (Govaerts et al. 2007), apenas 16\% têm o número cromossômico conhecido, e metade destes números foram descritos para espécies de Carex L. (Roalson 2008). Apesar da escassez de conhecimento da evolução cromossômica nesta família (Hipp et al. 2009), a literatura indica que o processo de diferenciação dos cariótipos varia entre os grupos. Em Carex, agmatoploidia (quebra) e simploidia (fusão) são consideravelmente mais freqüentes (Hipp et al. 2009), quando comparado com outros gêneros, como Rhynchospora Vahl (Luceño et al. 1998 e Vanzela et al. 2000), Scleria PJ Bergius (Yano e Hoshino 2007) e Eleocharis (Yano et al. 2004, Da Silva et al. 2008a e Da Silva et al. 2010), nas quais a poliploidia é a principal causa de alterações nos números cromossômicos.

Neste contexto, não podemos descartar a possibilidade da existência de algum controle genético que favoreça a agmatoploidia e/ou simploidia em espécies diferentes. No entanto, a falta de estudos envolvendo um maior número de populações em uma mesma espécie, contribui para esta lacuna no conhecimento da evolução cromossômica em Cyperaceae. Estudos citogenéticos em diversas populações de uma determinada espécie podem revelar alterações cromossômicas que não são detectadas em amostras pequenas. As quais podem ser importantes na compreensão da evolução do cariótipo 
desses grupos (Luceño e Castroviejo 1991, Hoshino e Okamura 1994, Ohkawa et al. 2000, Bureš et al. 2004 e Da Silva et al. 2008b).

Estudos citogenéticos em Eleocharis datam de antes de 1924, quando Piech descreveu o número de cromossomos de E. prostes (veja Nijalingappa 1973). Atualmente, a literatura tem registrado uma considerável variação no número cromossômico de espécies deste gênero, sendo de $2 n=6$ para $E$. subarticulata (Da Silva et al. 2005) a $2 n=200$ para E. dulcis (veja Roalson 2008). Variações intraespecíficas têm sido apontadas em algumas populações de E. geniculata, $\operatorname{com} 2 n=$ 10 e 20 (Sanyal e Sharma 1972 e Nijalingapa 1973), E. uniglumis com 2n = 46, 78-82 e E. palustris com 2n = 14-17, 38 e 39, (Bureš 1998 e Bureš et al. 2004), E. aciculares f. longiseta com $2 n=20$ e 21 (Yano et al. 2004) e E. maculosa com $2 n=10,8$, 7 e 6 (Da Silva et al. 2008b). Apesar dessa variação, a maioria das espécies possui números múltiplos de 5 (Da Silva et al. 2008a, Roalson 2008) tal número, $x=5$, foi proposto como o número básico para a família por Löve et al. (1957).

\subsubsection{Meiose nas Cyperaceae}

A família Cyperaceae é conhecida pela ocorrência de meiose pós-reducional ou invertida. Este comportamento meiótico foi sugerido pela primeira vez em Carex por Heilborn (1928) e Wahl (1940). Este tipo de meiose, ocorre quando as cromátides irmãs apresentam orientação paralela na placa equatorial na metáfase I, migrando uma para cada lado na anáfase I. Com isso, o número de cromossomos não se reduz durante a primeira fase

Figura 8. Cromossomos meióticos em coloração convencional com Giemsa em Metáfase I de Eleocharis capillacea, com cinco bivalentes da meiose, já que o que se reduz é o número de formando estrutura em caixa. 
cromátides de cada cromossomo. Nos cromossomos monocêntricos, as cromátides irmãs apresentarem orientação perpendicular ao eixo longo da placa equatorial antes da anáfase I, o que proporciona a separação dos cromossomos homólogos (meiose reducional).

O alinhamento dos bivalentes na meiose de holocêntricos gera uma configuração conhecida como “estrutura em caixa” (Figura 8) (Vanzela et al. 2000). Contudo, apenas a ocorrência desta estrutura não é prova de que a meiose é invertida. A análise de toda a meiose seria necessária para confirmar este comportamento. A meiose invertida foi bem documentada em E. subarticulata, na qual apesar da inexistência de bivalentes, pôde-se ver claramente que durante a primeira fase da meiose ocorre a separação das cromátides irmãs e, com isso, o número de cromossomos não é reduzido durante a anáfase I, ocorrendo a redução somente durante a segunda fase da meiose (Da Silva et al. 2005). Este tipo de comportamento meiótico foi sugerido para vários outros gêneros de Cyperaceae, como Carex (Wahl 1940), Rhynchospora (Vanzela et al. 2000) e também nos gêneros Cuscuta, da família Cuscutaceae (Pazi e Plitman 1994) e Luzula, da família Juncaceae (Nordenskiöld 1951). Além dos vegetais, alguns grupos de insetos que possuem cromossomos holocêntricos também apresentam meiose invertida; no entanto, diferentemente dos vegetais, nos quais este tipo de meiose ocorre para todos os cromossomos, em alguns grupos de insetos apenas os cromossomo sexuais, no sexo heterogamético, sofrem meiose invertida (Solari 1979).

Além de possuir cromossomos holocêntricos e meiose invertida, a família Cyperaceae exibe também a ausência de tétrades com formação de pseudomônades, vista também na família Epacridaceae (Brown e Lemmon 2000). Ao final da meiose tradicional, os núcleos se organizam em uma tétrade (McCormick 1993) e são gerados ao final quatro grãos de pólen (gametófitos). Em Cyperaceae, no entanto, três dos quatro 
núcleos são degenerados e apenas um torna-se funcional (Furness e Rudall 1999, San Martins et al. 2009). Após o amadurecimento da pseudomônade, apenas um androgametófito é formado (Furness e Rudall 1999).

\subsection{Localização de DNA repetitivo}

Existe uma grande variação tanto na quantidade quanto na disposição de bandas heterocromáticas em cromossomos de angiospermas, e esta variação pode ser vista até mesmo entre espécies próximas (Rego et al. 2009). Apesar das técnicas de bandamento mostrarem muita eficácia para a compreensão da organização cromossômica, tais estudos ainda são escassos em espécies vegetais com cromossomos holocêntricos.

Dentre as técnicas mais empregadas, o bandamento- $C$ tem sido usado para localizar blocos de heterocromatina, enquanto que as colorações com fluorocromos DAPI (4`-6 diamidino - 2 fenilindol) e $\mathrm{CMA}_{3}$ (cromomicina $\mathrm{A}_{3}$ ), são úteis para determinar a composição de bases de heterocromatina. O DAPI liga-se preferencialmente em regiões cromossômicas ricas em adenina e timina (A-T), enquanto CMA liga-se preferencialmente em regiões ricas em citosina e guanina (C-G). O uso sequencial destes fluorocromos permite entender a composição e a dinâmica de muitas famílias de DNA altamente repetitivas nos genomas (Fregonezi et al. 2006).

Alguns estudos têm demonstrado que cromossomos holocêntricos podem exibir blocos definidos de heterocromatina em regiões terminais e intersticiais (Westerman e Collet 1984; Panzera et al. 1992; Sheikh e Kondo 1995). De fato, o padrão de distribuição de heterocromatina em cromossomos holocêntricos parece ser similar ao encontrado em monocêntricos (Guerra 2000). Vanzela e Guerra (2000) descreveram para seis espécies de Rhynchospora (Cyperaceae) três tipos de heterocromatina, $\mathrm{CMA}^{+} / \mathrm{DAPI}^{-}, \mathrm{CMA}^{+} / \mathrm{DAPI}^{+}$e $\mathrm{CMA}^{-} / \mathrm{DAPI}^{+}$, que variaram em tamanho e 
posicionamento nos cromossomos das espécies analisadas. No entanto, para sete espécies de Eleocharis foi observado apenas blocos de heterocromatina $\mathrm{CMA}^{-} / \mathrm{DAPI}^{+}$ terminais (Da Silva et al. 2008a) nos cromossomos metafásicos mitóticos. Porém, quando estes cromossomos foram analisados em prófase, estas regiões de heterocromatina apresentaram-se dispersas ao longo dos cromossomos em pequenas porções.

Muitos segmentos repetidos de DNA têm sido precisamente detectados e mapeados fisicamente pela técnica de hibridação in situ. No entanto, os sítios de DNA ribossomal são, sem dúvida, os mais estudados por FISH em espécies vegetais e animais. Poucos estudos foram realizados em espécies vegetais com cromossomos holocêntricos. Em Cuscuta approximata (Cuscutaceae), sítios de DNAr 45S foram detectados em um par e sítios de DNAr 5S em três pares (Guerra e García 2004). Para a família Cyperaceae, vários sítios de rDNA 45S foram detectados em 8 espécies de Rhynchospora (Vanzela et al. 1998). Neste trabalho os autores encontraram uma grande variação no número de sítios; espécies com $2 n=10$ apresentaram de 4 a 8 sítios e, até 30 sítios em espécies com $2 n=50$. Apesar desta variação numérica, o posicionamento dos sítios foi sempre terminal.

Furuta e Hoshino (1999) descreveram, para Eleocharis mamillata var. cyclocarpa $(2 n=16), 12$ sinais terminais com a sonda de DNAr $18 \mathrm{~S}$ e dois sinais intersticiais com sonda de DNAr 5S. Para outras sete espécies de Eleocharis, a sonda de DNAr 45S revelou sempre marcações terminais. Da Silva et al. (2008a) encontraram 10 marcações em E. flavescens $(2 n=10)$, oito em E. sellowiana $(2 n=20)$ e E. acutangula $(2 n=54)$ e quatro em E. maculosa $(2 n=10)$, E. geniculata $(2 n=20)$ e E. montana $(2 n$ = 40). Para E. subarticulata, dos seis cromossomos do complemento diplóide, quatro revelaram sítios de DNAr 45S (Da Silva et al. 2005). A posição terminal destes sítios 
permaneceu inalterada, até mesmo quando ocorrem rearranjos cromossômicos, como detectados em E. maculosa, na qual a simploidia foi responsável pela redução cromossômica de $2 n=10$ para $2 n=8$, 7 e 6 . Neste trabalho também foram detectados dois sítios de DNAr 5S em cada cariótipo, porém, estes sítios foram terminais e intersticiais dependendo do cariótipo analisado (Da Silva et al. 2008b).

Além de sondas de DNAr, outras sondas foram utilizadas em estudos com espécies de Cyperaceae. Em Rhynchospora tenuis, hibridações in situ com a sonda telomérica (TTTAGGG) de Arabidopsis thaliana revelaram sinais apenas nas extremidades dos cromossomos de ambas as raças cromossômicas ( $2 n=4$ e 8), e sinais intersticiais não foram encontrados (Vanzela et al. 2003). Sinais intersticiais também não foram detectados em E. maculosa que sofreram simploidia (Da Silva et al. 2008b). Porém, estudo realizado por Da Silva et al. (2005) com Eleocharis subarticulata, que possui um cariótipo originado por translocações múltiplas com apenas $2 n=6$, foram encontrados sítios ectópicos, adicionais aos sinais terminais. 


\section{Justificativa}

Cyperaceae é a terceira maior família de monocotiledôneas (Trevisan e Boldrini 2008). O gênero Eleocharis é o quarto maior em número de espécies no Brasil. Muitas destas são endêmicas de áreas alagadas e importantes para a formação de biomassa nesses ecossistemas, como E. interstincta (Dos Santos e Esteves, 2005). Pelo menos duas espécies E. acutangula e E. sellowiana possuem atividade moluscicidas (Ruiz et al. 2005), já outras são utilizadas como ornamentação (E. minima) e muitas são consideradas ervas daninhas, principalmente em plantações de arroz.

O gênero Eleocharis apresenta inúmeras discordâncias quanto ao posicionamento das espécies em subgêneros, seções e séries, e isto tem trazido indefinições sobre os aspectos evolutivos do grupo (Roalson et al. in press). A escassez de informações citogenéticas em Eleocharis, e nas Cyperaceae de um modo geral, tem dificultado a compreensão de como tais cariótipos se organizam e se modificam. Tendo em vista isso, torna-se evidente a necessidade de ampliar tais conhecimentos neste grupo de plantas com cromossomos pouco comuns, não só com o auxílio de citogenética, mas também da taxonomia, morfologia e genética molecular. 


\section{Objetivos}

Este trabalho tem como objetivo analisar, por parâmetros citogenéticos, moleculares e morfológicos, as relações entre as espécies do gênero Eleocharis, coletadas em vários estados do Brasil. Com estas análises, pretende-se esclarecer problemas taxonômicos e elaborar um modelo de diferenciação genético/cariotípica para um grupo vegetal com cromossomos especiais (holocêntricos).

\subsection{Objetivos Específicos}

(a) Coletar e identificar diferentes espécies e populações do gênero Eleocharis do território brasileiro para registrar a diversidade deste grupo;

(b) Determinar o número e a morfologia cromossômica de diferentes espécies pertencentes a diversas populações estudadas;

(c) Avaliar os mecanismos de diferenciação e evolução cariotípica em várias espécies de Eleocharis, pela aplicação das técnicas de coloração (i) convencional, (ii) bandamento cromossômico e (iii) hibridação in situ;

(d) Utilizar diferentes marcadores moleculares (RAPD) para diferenciar espécies e populações que tenham problemas taxonômicos evidentes;

(e) Elaborar um modelo evolutivo para o gênero baseado em características morfológicas e genéticas. 


\section{Referências}

Alves MV, Araújo AC, Prata AP, Vitta FA, Hefler SM, Trevisan R, Gil AB, Martins S, Thomas SWW (2009). Diversity of Cyperaceae in Brazil. Rodriguésia 60 (4): 112.

Araujo D, Rhemis CA, Brescovit AD, Cella DM (2008). Extreme degree of chromosome number variability in species of the spider genus Scytodes (Araneae, Haplogynae, Scytodidae). J Zool Syst Evol Res 46: 89 - 95.

Barros M (1960). Las Ciperáceas del estado de Santa Catarina. Sellowia 12: 1-430.

Bernardini J (1959). Studies of the kinetochore in Eleocharis macrostachya Britt. Proc. Monnesota Acad. Sci. 27: 104-114.

Brown RC, Lemmon BE (2000). The cytoskeleton and polarization during pollen development in Carex blanda (Cyperaceae). Amer J. Bot. 87: 1-11.

Bruhl JJ (1995). Sedge genera of the world: relationships and a new classification of the Cyperaceae. Aust J Bot 8: 125-305.

Buchwitz BJ, Ahmad K, Moore LL, Roth MB, Henikoff S (1999). A histone-H3-like protein in C. elegans. Nature 401:547-548.

Bureš P (1998). A high polyploidy Eleocharis uniglumis S.L. (Cyperaceae) from central and southeastern Europe Folia Geobot 33: 429-439. 
Bureš P, Rotreklová O, Stoneberg HSD, Pikner R (2004). Cytogeographical survey of Eleocharis subser. Eleocharis in Europe 1. Eleocharis palustris. Folia Geobot 39: 235-257.

Castro D, Camara A, Malheiros N (1949). X-rays in the centromere problem of Luzula purpurea Link. Gen. Iber. 1: 49-54

Dahlgren RMT, Clifford HT, Yeo PF (1985). The families of the monocotyledons: structure, evolution and taxonomy. Berlin: Springer-Verlag.

Da Silva CRM, González-Elizondo MS, Vanzela ALL (2005). Reduction of chromosome number in Eleocharis subarticulata (Cyperaceae) by multiple translocations. Bot. J. Linn. Soc. 149, 457-464.

Da Silva CRM, González-Elizondo MS, Rego LNAA, Torezan JMD, Vanzela ALL (2008a). Cytogenetical and cytotaxonomical analysis of some Brazilian species of Eleocharis. Aust J Bot 56: 82-90.

Da Silva CRM, González-Elizondo MS, Vanzela ALL (2008b). Chromosome Reduction in Eleocharis maculosa (Cyperaceae). Cytogenetic Genome Res 122, 175-180. 
Da Silva CRM, Trevisan R, González-Elizondo MS, Ferreira JM, Vanzela ALL (2010). Karyotypic diversification and its contribution to the taxonomy of Eleocharis (Cyperaceae) from Brazil. Aust J Bot 58: 1-12

Dos Santos AM, Esteves FA (2005). Influence of Water Level Fluctuation on the Mortality and Aboveground Biomass of the Aquatic Macrophyte Eleocharis interstincta (VAHL) Roemer et Schults. Brazilian Archives of Biology and Technology 47: 281-290

Flach M (1966). Diffuse centromeres in a dicotyledonous plant. Nature 209: 1369_ 1370.

Fregonezi JN, Fernandes T, Torezan JMD, Vieira AOS and Vanzela ALL (2006). Karyotype differentiation of four Cestrum species (Solanaceae) based on physical mapping of repetitive DNA. Gen Mol Biol 29:97-104.

Furness CA, Rudall PJ (1999). Microsporogenesis in monocotyledons. Ann Bot 84: 7599.

Furuta K, Hoshino T (1999). Localization of the 18S and 5S rDNA on the chromosomes non-localized centromere in Cyperaceae. XVI International Botanical congress. Abstract Number: 4331 Poster No. 1829.

Gil ASB, Bove CP (2007). Eleocharis R.Br. (Cyperaceae) no Estado do Rio de Janeiro, Brasil. Biota Neotropica 7: 163 - 193. 
Goetghebeur P (1998). Cyperaceae. Pp. 141-190. In: Kubitzki, K. (ed.). The families and genera of vascular plant: IV. Flowering plants - monocotyledons. Berlin: Springer-Verlag.

González-Elizondo MS (1994). Eleocharis R. Br. (Cyperaceae) Pp. 458-464. In: Davidse, G., Souza, M. \& Chater, A. O. (eds.). Flora Mesoamericana. Alismataceae a Cyperaceae 6. Mexico: Universidad Nacional Atónoma de Mexico, Missouri Botanical Garden, The Natural History Museum (London).

González-Elizondo MS, Peterson PM (1997). A classification of and key to the supraspecific taxa in Eleocharis (Cyperaceae). Taxon 46: 433-449.

Govaerts R, Simpson D, Bruhl J, Egorova T, Goetghebeur P, Wilson K (2007). World checklist of Cyperaceae - Sedges. Kew Gardens, Surrey.

Guerra MS (2000). Patterns of heterochromatin distribution in plant chromosomes. Genet. Mol. Biol. 23: 1029-1041.

Guerra M, García MA (2004). Heterochromatin and rDNA sites distribution in the holocentric chromosomes of Cuscuta approximata Bab. (Convolvulaceae). Genome 47: 134-140. 
Guerra M, Brasileiro-Vidal AC, Arana P, Puertas MJ (2006) Mitotic microtubule development and histone H3 phosphorylation in the holocentric chromosomes of Rhynchospora tenuis (Cyperaceae). Genetica 126: 33-41.

Håkansson A (1954). Meiosis and pollen mitosis in x-rayed and untreated spikelets of Eleocharis palustris. Hereditas (Lund) 15: 325-345.

Håkansson A (1958) Holocentric chromosomes in Cyperaceae. Hereditas 11: 182-192.

Harms LJ (1968). Cytotaxonomic studies in Eleocharis Subser. Palustres: Central united States Taxa. Amer J. Bot. 55: 966-974.

Hipp AL, Rothrock PE, Roalson EH (2009). The evolution of chromosome arrangements in Carex (Cyperaceae). Bot Rev 75: 96-109.

Heilborn O (1928). Chromosome studies in Cyperaceae. Hereditas 11: 182-192.

Hoshino T (1987) Karyomorphological studies on 6 taxa of Eleocharis in Japan. Bulletin of the Okayama University of Science 22, 305-312.

Hoshino T, Okamura K (1994). Cytological studies on meiotic configurations of intraspecific aneuploids of Carex blepharicarpa (Cyperaceae) in Japan. J Plant Res 107: 1-8. 
Judd WS, Campbell CS, Kellogg EA, Stevens PF (1999). Systematics: a philogenetic approach. Sinauer Associates, Inc: Massachusetts. USA.

Koyama T (1961). Classification of the family Cyperaceae. J. Fac. Sci. Univ. Tokyo, Sect. 3. Bot. 8: 37-148.

Kukkonen I (1990). On the genus Eleocharis (Cyperaceae) in the flora Iranica area, with revised infrageneric classification and nomenclature. Ann. Bot. Fenn. 27: 109-117.

Kunth CS (1937). Enumeration plantarum omnium hucusque cognitarum. 2. Cyperographia synoptica.

Löve A, Löve D, Raymond M (1957). Cytotaxonomy of Carex section Capillares. Can. J. Bot. 35: 715-761.

Luceño M, Castroviejo S (1991). Agmatoploidy in Carex laevigata (Cyperaceae): Fusion and fission of chromosomes as the mechanism of cytogenetic evolution in Iberian populations. Pl. Syst. Evol. 177: 149-160.

Luceño M, Alves M, Mendes AP (1997). Catálogo florístico y claves de identificación de lãs Cyperaceae de los estados de Paraíba y Pernambuco (Nordeste de Brasil). Anales del Jardín Botánico de Madrid 55: 67-100. 
Luceño M, Guerra M (1997). Numerical variation in species exhibiting holocentric chromosomes: a nomeclatura proposal. Caryologia 49: 301-309.

Luceño M, Vanzela ALL, Guerra M (1998). Cytotaxonomic studies in Brazilian Rhynchospora (Cyperaceae), a genus exhibiting holocentric chromosomes. Can. J. Bot. 76: 440-449.

Lye KA (2000). Achene structure and function of structure in Cyperaceae. Pp. 615-628. In: Wilson, K. L. \& Morrison, D. A. (eds.). Monocots: Systematics and Evolution. Melbourne: CSIRO.

Malheiros N, De Castro D, Câmara A, (1947). Cromosomas sem centrômero localizado. Agron. Lusitana 9: 57-74.

McCormick S (1993) Male gametophyte development. Plant Cell 5: 65-75.

Menapace FJ (1990). A preliminary micromorphological analysis of Eleocharis (Cyperaceae) achenes for systematic potencial. Can. J. Bot. 69: 1533-1541.

Mohlenbrock RH (1976). The illustrated Flora of Illinois. Sdges - Cyperus to Scleria. London: Southern Illinois University Prees.

Muasya AM, Simpson DA, Verboom GA, Goetghebeur P, Naczi RFC, Chase MW, Smets E (2009). Phylogeny of Cyperaceae Based on DNA Sequence Data: Current Progress and Future Prospects. Bot. Rev. 75:2-21 
Muasya AM, Bruhl JJ, Simpson DA, Culham A, Chase MW (2000). Suprageneric phylogeny of Cyperaceae: a combined analysis. Pp. 593-601. In: Wilson, K. L. \& Morrison, D. A. (eds.). Monocots: Systematics and Evolution. Melbourne: CSIRO.

Nagaki K, Kashihara K, Murata M (2005). Visualization of diffuse centromeres with centromere-specific histone H3 in the holocentric plant Luzula nivea. The Plant Cell 17, 1886-1893.

Nees TFL (1834). No III. Cyperaceae indicae. Praecipue juxta herbaria Wightii, Wallichii, Roylei et Lindleyi. Pp 69-129 in: Wight, R., Contributions to the botany of india. London.

Nees TFL (1835). Uebersicht der Cyperaceengattungen. Linnaea 9:273-306.

Nees C (1842). Cyperaceae. In: Martius, C. (ed.). Flora brasiliensis. Munich. Vol. 2. Pp.1-226.

Nijalingappa BHM (1973). Cytological studies in Eleocharis. Caryologia 26: 512-520.

Nokkala S, Laukkanen A, Nokkala C (2002). Mitotic and meiotic chromosomes in Somatochlora metallica (Cordulidae, Odonata). The absence of localized centromeres and inverted meiosis. Hereditas 136: 7-12. 
Nordenskiöld H (1951). Cyto-taxonomical studies in the genus Luzula I. Somatic chromosomes and chromosomes numbers. Hereditas 37: 325-355.

Ohkawa T, Yokota M, Hoshino T (2000). Aneuploidal population differentiation in Carex sociata Boott (Cyperaceae) of the Ryukyu Islands, Japan. Bot. J. Linn. Soc 132: 337-358.

Panzera F, Álvarez F, Sánchez-rufas J, Pérez R, Sujas JA, Scvortzoff E, Dujardinni JP, Estramil E, Salvatella R (1992). C-heterocromatin polymorphism in holocentric cromosomes of Triatoma infestans (Hemíptera-Reduviidae) Genoma 35: 10681074.

Pazy B, Plitman U (1994). Holocentric chromosome behaviour in Cuscuta (Cuscutaceae). Plant Syst. Evol. 191: 105-109.

Perez R, Rufas JS, Suja JA, Page J, Panzera F (2000). Meiosis in holocentric chromosomes: Orientation and segregation of an autosome and sex chromosomes in Triatoma infestans (Heteroptera). Chrom Res 8: 17-25.

Prata AP (2002). Listagem florística das Cyperaceae do estado de Roraima, Brasil. Hoehnea 29: 93-107.

Rego LNAA, Da Silva CRM, Torezan JMD, Gaeta ML, Vanzela ALL (2009). Cytotaxonomical study in Brazilian species of Solanum, Lycianthes and Vassobia (Solanaceae). Plant Syst Evol 279: 93-102. 
Roalson EH, Friar EA (2000). Infrageneric classification of Eleocharis (Cyperaceae) revisited: evidence from the Internal Transcribed Spacer (ITS) region of nuclear ribosomal DNA. Syst Bot 25: 323-336.

Roalson EH (2008). A synopsis of chromosome number variation in the Cyperaceae. Bot Rev 74: 209-393

Roalson EH, Hinchliff CE, Trevisan R, Da Silva CRM (in press). Phylogenetic relationships in Eleocharis (Cyperaceae): C4 photosynthesis origins and patterns of diversification in the spikerushes. Syst Bot 35: $\mathrm{xxx}-\mathrm{xxx}$.

Ruiz ALTG, Magalhães EG, Magalhães AF, Faria AD, Amaral MCE, Serrano DR, Zanotti-Magalhães EM, Magalhães AL (2005). Avaliação da atividade tóxica em Artemia salina e Biomphalaria glabrata de extratos de quatro espécies do gênero Eleocharis (Cyperaceae) Braz J Pharma 15: 98-102

San Martins JAB, Andrade CGTJ, Vanzela ALL (2009). Early meiosis in Rhynchospora pubera L. (Cyperaceae) is marked by uncommon ultrastructural features Cell Biol Int 33: 1118-1122.

Sanyal B, Sharma AK (1972). Cytological studies in Indian Cyperaceae. I. Tribe Scirpeae. Cytologia 37: 13-32.

Scharader F (1935). Notes on the mitotic behavior of long chromosomes. Cytologia. 6: 422-430. 
Schneider MC, Zacaro AA, Pinto-Da-Rocha R, Candido DM, Cella DM (2009). A Comparative Cytogenetic Analysis of 2 Bothriuridae Species and Overview of the Chromosome Data of Scorpiones. J Hered 100:545-555.

Sheikh SA, Kondo K (1995) Differential staining with orcein, giemsa CMA, and DAPI for comparative chromosome study of 12 species of Australian Drosera (Droseraceae). Amer J. Bot. 82, 1278-1286.

Simpson DA (1988). Some problems in Eleocharis. Notes on Brazilian Cyperaceae: III. Kew Bulletin, 43(1): 127-134.

Simpson DA, Furness CA, Hodkinson TR, Muasya AM, Chase MW (2003). Phylogenetic relationships in Cyperaceae Subfamily Mapaniodeae inferred from pollen and plastid DNA sequence data. Amer J. Bot. 90: 1071-1086.

Simpson DA, Muasya AM, Alves MV, Bruhl JJ, Dhooge S, Chase MW, Furness CA, Ghamkhar K, Goetghebeur P, Hodkinson TR, Marchant AD, Nieuborg R, Reznicek AA, Roalson EH, Smets E, Starr JR, Thomas WW, Wilson KL, Zhang X (2007). Phylogeny of Cyperaceae based on DNA sequence data-A new rbcL analysis. Aliso 23: 72-83.

Solari AJ (1979). Autosomal synaptonemal complex and sex chromosomes without axes in Triatoma infestans (Reduviidae, Hemiptera). Chromosoma 72:225-240. 
Strandhede SO (1965) Chromosome studies in Eleocharis, subser. Palustres. Opera Bot 9, 1-86.

Svenson HK (1929). Monographic Studies in the Genus Eleocharis I. Rhodora 31: 121242.

Svenson HK (1932). Monographic Studies in the Genus Eleocharis II. Rhodora 34: 193-227.

Svenson HK (1934). Monographic Studies in the Genus Eleocharis III. Rhodora 36: 377-389.

Svenson HK (1937). Monographic Studies in the Genus Eleocharis IV. Rhodora 39: 210-273.

Svenson HK (1939). Monographic Studies in the Genus Eleocharis V. Rhodora 41: 1110.

Tanaka N, Tanaka N (1977). Chromosome studies in Chionographis (Liliaceae) I. On the holokinetic nature of chromosomes in Chionographis japonica Maxim. Cytologia 42: 753-763.

Torrey J (1836). Monograph of North American Cyperaceae. Ann. Lyceum Nat. Hist. New York 3: 239-448.

Trevisan R, Boldrini II (2008). O gênero Eleocharis R. Br. (Cyperaceae) no Rio Grande do Sul, Brasil. Revista Brasileira de Bociências 6, 7-67. 
Ueno O, Samejima M, Koyama T (1989). Distribution and evolution of C4 syndrome in Eleocharis, a sedge group inhabiting wet and aquatic environments, based on culm anatomy and carbon isotope ratios. Ann Bot. 64: 425-438.

Vanzela ALL, Guerra M, Luceño M (1996) Rhynchospora tenuis Link (Cyperaceae), a species with the lowest number of holocentric chromosomes $(n=2)$. Cytobios 88, 219-228.

Vanzela ALL, Cuadrado A, Jouve N, Luceño M, Guerra M (1998). Multiple locations of the rDNA sites in holocentric chromosomes of Rhynchospora (Cyperaceae). Chrom Res 6: 345-349.

Vanzela ALL, Guerra M (2000). Heterochromatin differentiation in holocentric chromosomes of Rhynchospora (Cyperaceae) Genet. Mol. Biol. 2: 453-456.

Vanzela ALL, Luceño M, Guerra M (2000). Karyotype evolution and cytotaxonomy in Brazilian species of Rhynchospora Vahl (Cyperaceae). Bot. J. Linn. Soc. 134: 557-566.

Vanzela ALL, Colaço W (2002). Mitotic and meiotic behavior of $\gamma$ irradiated holocentric chromosomes of Rhynchospora pubera (Cyperaceae). Act Scientiarum 2: 611-614. 
Vanzela ALL, Cuadrado A, Guerra M (2003). Localization of 45S rDNA and telomeric sites on holocentric chromosomes of Rhynchospora tenuis Link (Cyperaceae). Gen Mo Bio 26: 199-201.

Yano O, Katsuyama T, Tsubota H, Hoshino T (2004). Molecular phylogeny of Japanese Eleocharis (Cyperaceae) based on ITS sequence data, and chromosomal evolution. J Plant Res 117, 409-419.

Yano O, Hoshino T (2007). Karyomorphological Studies of Four Species of Japanese Scleria (Cyperaceae). Cytologia 72: 275-278.

Wahl HA (1940). Chromosome numbers and meiosis in the genus Carex. Amer. J. Bot. 27: 458-470.

Wang B, Porter AH (2004). An AFLP-based interspecific linkage map of sympatric, hybridizing Colias butterflies. Genetics 168: 215-225.

Westerman M, Colle C (1984). Interspersed distribution patterns of c-bands and satellite DNA in the holocentric chromosomes of Luzula flaccida (Juncaceae). Genetica 63: 175-179. 


\section{Capítulo 1}

Karyotypic diversification and its contribution to the taxonomy of Eleocharis (Cyperaceae) from Brazil 


\title{
Karyotypic diversification and its contribution to the taxonomy of Eleocharis (Cyperaceae) from Brazil
}

\author{
Carlos Roberto Maximiano da Silva ${ }^{\mathrm{A}}$, Rafael Trevisan ${ }^{\mathrm{B}}$, Maria Socorro González-Elizondo ${ }^{\mathrm{C}}$, \\ Josué Maldonado Ferreira ${ }^{\mathrm{D}}$ and André Luís Laforga Vanzela ${ }^{\mathrm{D}, \mathrm{E}, \mathrm{F}}$ \\ A Universidade Estadual Paulista, Departamento de Biologia, Instituto de Biociências, Letras e Ciências Exatas, \\ (UNESP/IBILCE), 15054-000 São José do Rio Preto, SP, Brazil. \\ B Instituto de Biociências, Universidade Federal do Rio Grande do Sul, 91501-970 Porto Alegre, RS, Brazil. \\ ${ }^{\mathrm{C} C e n t r o ~ I n t e r d i s c i p l i n a r i o ~ d e ~ I n v e s t i g a c i o ́ n ~ p a r a ~ e l ~ D e s a r r o l l o ~ I n t e g r a l ~ R e g i o n a l, ~ I P N, ~ S i g m a ~} 119$ Fracc. 20 de \\ Noviembre II, 34220 Durango, Dgo., Mexico. \\ DDepartamento de Biologia Geral, Centro de Ciências Biológicas, Universidade Estadual de Londrina, \\ 86051-970 Londrina, PR, Brazil. \\ ELaboratório de Biodiversidade e Restauração de Ecossistemas, Departamento de Biologia Geral, Centro de \\ Ciências Biológicas, Universidade Estadual de Londrina, Londrina, Paraná, CEP 86051990, Caixa Postal 6001. \\ ${ }^{\mathrm{F}}$ Corresponding author. Email: andrevanzela@uel.br
}

\begin{abstract}
A karyotype analysis of 147 populations of 25 Brazilian species of Eleocharis (Cyperaceae) was carried out, including representatives of the three subgenera that occur in the country: Limnochloa, Scirpidium and Eleocharis. The analyses showed chromosomes without centromeres, but with terminal nucleolar constrictions (satellites) in some chromosomes. The chromosome numbers varied from $2 n=6$ in E. subarticulata and E. maculosa to $2 n=60$ in E. laeviglumis, but the chromosome basic number $x=5$ was confirmed. Species of the subgenera Eleocharis and Scirpidium possess fewer and larger chromosomes, while those in the subgenus Limnochloa have small and more numerous chromosomes. These features indicate that the karyotypes of the subgenera Eleocharis and Scirpidium are more closely related, in agreement with morphological and phylogenetical data. The representatives of the section Eleocharis exhibited the largest differences in chromosome number and size, probably due to chromosome fission and fusion. Polyploidy was the most common event in this group. Nevertheless, most of the studied species exhibited regular meiosis with only bivalent formation, even the polyploids, such as in E. geniculata and E. sellowiana. The cytogenetic information obtained showed quite variable karyotypes with chromosomes gradually decreasing in size, and predominance of polyploidy. These results are useful in the differentiation of the subgenera.
\end{abstract}

\section{Introduction}

Eleocharis R.Br. (Cyperaceae) is a genus with a worldwide distribution, including more than 200 species with a remarkable richness in South America (González-Elizondo and Tena-Flores 2000). The relatively simple morphology associated with a great phenotypic variation make difficult the identification and delimitation of the species (Simpson 1988; GonzálezElizondo and Peterson 1997; Trevisan and Boldrini 2008). There are few morphological characters that have taxonomic value in Eleocharis and several of them may be over-weighted, for example the ornamentation of the achenes and the number of style branches, which shows a high degree of homoplasy (González-Elizondo and Peterson 1997).

The supraspecific classifications that have been proposed for Eleocharis, for example, Svenson (1929, 1939), Kukkonen (1990) and González-Elizondo and Peterson (1997), are based on morphological data, and can be considered preliminary due to the scarce diagnostic features. When morphology is compared with the current phylogenetic hypothesis, it seems to be clear that many morphological characters are either pleisiomorphic or have multiple origins (Roalson and Hinchliff 2007). To understand the evolutionary process in this group of plants, reviews are necessary that combine different approaches, as morphological, anatomical, cytogenetical and molecular markers, as suggested by González-Elizondo and Peterson (1997) and Roalson and Friar (2000). Molecular and cytogenetical analyses were useful to understand the evolutionary profile of two Cyperaceae genera from Japan. Fimbritylis Vahl was considered monophyletic and composed by three karyotype groups (Yano and Hoshino 2006a) and Schoenoplectus (Rchb.) with two clades with predominance of polyploidy (Yano and Hoshino 2005).

Eleocharis, as well as the other representatives of Cyperaceae, possess holocentric chromosomes, inverted meiosis and absence of tetrads with pseudomonad formation (Wahl 1940; Davies 1956; Strandhede 1965; Faulkner 1972). This family exhibits a wide range of chromosome numbers (Roalson 2008), originated by fusion (symploidy), fission (agmatoploidy) and polyploidy 
Table 1. Karyotype features of Brazilian species of Eleocharis R.Br. Species are grouped according to the supraspecific classification of GonzálezElizondo and Peterson (1997)

Vouchers were deposited at the ICN herbarium of the Universidade Federal do Rio Grande do Sul, Porto Alegre, Brazil

\begin{tabular}{l}
\hline Species \\
\hline Subgenus Eleocharis \\
Section Eleogenus (Nees) \\
$\quad$ Benth. and Hook. f. (1883) \\
E. maculosa (Vahl) Roem. \\
$\quad$ and Schult.
\end{tabular}

E. capillacea Kunth $^{\mathrm{A}}$

10

2.1-1.4

E. flavescens (Poir.) Urb.

E. geniculata (L.) Roem. and Schult.

E. sellowiana Kunth

20

10

20

7.44

10

10

0

14.77

6.70

(7.
$2.3-1.8$

4.4-2.0

$4.3-1.8$

$4.4-1.8$

$1.6-1.2$
$1.4-1.1$

$2.4-1.7$

$1.7-1.2$

$2.0-1.2$

\section{E. debilis Kunth ${ }^{\mathrm{A}}$}

Section Eleocharis

E. minima Kunth
E. contracta Maury ${ }^{\mathrm{A}}$
20

19.42 $30^{\circ} 12^{\prime} 08^{\prime} \mathrm{S} 50^{\circ} 12^{\prime} 52^{\prime} \mathrm{W}$, Balneário Pinhal, RS (158385) $19^{\circ} 13^{\prime} 20^{\prime} \mathrm{S} 43^{\circ} 33^{\prime} 32^{\prime} \mathrm{W}$, Serra do Cipó, MG (158386) $19^{\circ} 32^{\prime} 52^{\prime} \mathrm{S} 43^{\circ} 44^{\prime} 29^{\prime} \mathrm{W}$, Jaboticatubas, MG (158390) $28^{\circ} 09^{\prime} 20^{\prime} \mathrm{S} 48^{\circ} 51^{\prime} 78^{\prime} \mathrm{W}$, Apiaí, SP (158387) $24^{\circ} 21^{\prime} 58^{\prime} \mathrm{S} 49^{\circ} 02^{\prime} 06^{\prime} \mathrm{W}$, Palmitalzinho, SP (158389) $22^{\circ} 15^{\prime} 54^{\prime} \mathrm{S} 47^{\circ} 55^{\prime} 30^{\prime} \mathrm{W}$, Brotas, SP (152642) $22^{\circ} 36^{\prime} 45^{\prime} \mathrm{S}$ $50^{\circ} 23^{\prime} 57^{\prime} \mathrm{W}$, Assis, SP $(26) 24^{\circ} 11^{\prime} 47^{\prime} \mathrm{S} 49^{\circ} 07^{\prime} 09^{\prime} \mathrm{W}$, Bom Sucesso do Itararé, SP (239) $19^{\circ} 13^{\prime} 20^{\prime} \mathrm{S}$ $43^{\circ} 33^{\prime} 32^{\prime} \mathrm{W}$, Serra do Cipó, MG $(152652 ; 152661)$ $19^{\circ} 04^{\prime} 13^{\prime} \mathrm{S} 43^{\circ} 24^{\prime} 58^{\prime} \mathrm{W}$, Conceição do Mato Dentro, MG (133)

$25^{\circ} 50^{\prime} 53^{\prime} \mathrm{S} 48^{\circ} 32^{\prime} 50^{\prime} \mathrm{W}$, Caiobá, PR (156144)

$09^{\circ} 05^{\prime} 39^{\prime} \mathrm{S} 35^{\circ} 16^{\prime} 23^{\prime} \mathrm{W}$, Japaratinga, AL (8) $25^{\circ} 50^{\prime} 53^{\prime} \mathrm{S}$ $48^{\circ} 32^{\prime} 50^{\prime} \mathrm{W}$, Caiobá, PR (156140)24 $53^{\prime} 60^{\prime} \mathrm{S}$ $50^{\circ} 18^{\prime} 80^{\prime} \mathrm{W}$, Ponta Grossa, PR (2) $08^{\circ} 23^{\prime} 50^{\prime} \mathrm{S}$ $35^{\circ} 05^{\prime} 42^{\prime} \mathrm{W}$ Ipojuca, PR (10)

$20^{\circ} 34^{\prime} 51^{\prime} \mathrm{S} 51^{\circ} 36^{\prime} 36^{\prime} \mathrm{W}$, Vestia, MS (69)07 $07^{\circ} 45^{\prime} 10^{\prime} \mathrm{S}$ $34^{\circ} 51^{\prime} 38^{\prime} \mathrm{W}$, Itamaracá, $\mathrm{PE}(9) 23^{\circ} 14^{\prime} 03^{\prime} \mathrm{S} 44^{\circ} 45^{\prime} 28^{\prime} \mathrm{W}$, Paraty, RJ (74)

$25^{\circ} 17^{\prime} 48^{\prime} \mathrm{S} 49^{\circ} 54^{\prime} 42^{\prime} \mathrm{W}$, Tibagi, PR (152018) $25^{\circ} 28^{\prime} 74^{\prime} \mathrm{S}$ $49^{\circ} 52^{\prime} 93^{\prime} \mathrm{W}$, São Luis do Purunã, PR (152019) $22^{\circ} 29^{\prime} 42^{\prime} \mathrm{S} 50^{\circ} 17^{\prime} 06^{\prime} \mathrm{W}$, Echaporã, SP (4) $26^{\circ} 16^{\prime} 46^{\prime} \mathrm{S}$ $51^{\circ} 03^{\prime} 24^{\prime} \mathrm{W}$, Porto União, SC (84)29 $29^{\circ} 48^{\prime} 18^{\prime} \mathrm{S}$ $50^{\circ} 03^{\prime} 45^{\prime} \mathrm{W}$, Xangri-lá, RS (225)

$21^{\circ} 45^{\prime} 13^{\prime} \mathrm{S} 48^{\circ} 59^{\prime} 55^{\prime} \mathrm{W}$, Ibitinga, SP (151980 and 3) $22^{\circ} 29^{\prime} 42^{\prime} \mathrm{S} 50^{\circ} 17^{\prime} 06^{\prime} \mathrm{W}$, Echaporã, SP (151994) $22^{\circ} 32^{\prime} 51^{\prime} \mathrm{S} 50^{\circ} 21^{\prime} 18^{\prime} \mathrm{W}$ Assis, SP (152006) $26^{\circ} 51^{\prime} 31^{\prime} \mathrm{S}$ $50^{\circ} 49^{\prime} 54^{\prime} \mathrm{W}$, Caçador, SC (152011)26 $6^{\circ} 14^{\prime} 56^{\prime} \mathrm{S}$ $49^{\circ} 54^{\prime} 27^{\prime} \mathrm{W}$, Mafra, SC (152022) $26^{\circ} 42^{\prime} 24^{\prime} \mathrm{S}$ $51^{\circ} 35^{\prime} 11^{\prime} \mathrm{W}$, Irani, SC (204) $25^{\circ} 50^{\prime} 53^{\prime} \mathrm{S} 48^{\circ} 32^{\prime} 50^{\prime} \mathrm{W}$, Caiobá, PR (156143) $25^{\circ} 17^{\prime} 48^{\prime} \mathrm{S} 49^{\circ} 54^{\prime} 42^{\prime} \mathrm{W}$, Tibagi, PR (152018)24 $4^{\circ} 57^{\prime} 40^{\prime} \mathrm{S} 53^{\circ} 26^{\prime} 12^{\prime} \mathrm{W}$, Cascavel, PR (391) $46^{\circ} 29^{\prime} 51^{\prime} \mathrm{S} 21^{\circ} 49^{\prime} 42^{\prime} \mathrm{W}$, Poços de Caldas, MG (152645) $19^{\circ} 04^{\prime} 13^{\prime} \mathrm{S} 43^{\circ} 24^{\prime} 58^{\prime} \mathrm{W}$, Conceição do Mato Dentro, MG (152656)20 $38^{\prime} 42^{\prime} \mathrm{S} 46^{\circ} 21^{\prime} 24^{\prime} \mathrm{W}$, Furnas, MG (152663)19 $32^{\prime} 52^{\prime} \mathrm{S} 43^{\circ} 44^{\prime} 29^{\prime} \mathrm{W}$, Jaboticatubas, MG (152665) $19^{\circ} 13^{\prime} 20^{\prime} \mathrm{S} 43^{\circ} 33^{\prime} 32^{\prime} \mathrm{W}$, Serra do Cipó, MG (152669) $21^{\circ} 34^{\prime} 08^{\prime} \mathrm{S} 45^{\circ} 46^{\prime} 77^{\prime} \mathrm{W}$, Paraguaçu, MG (200) $19^{\circ} 42^{\prime} 49^{\prime} \mathrm{S} 51^{\circ} 08^{\prime} 31^{\prime} \mathrm{W}$, Paranaíba, MS (152672) $20^{\circ} 10^{\prime} 30^{\prime} \mathrm{S} 51^{\circ} 12^{\prime} 54^{\prime} \mathrm{W}$, Aparecida do Taboado, MS (62) $30^{\circ} 06^{\prime} 18^{\prime} \mathrm{S}$ $50^{\circ} 44^{\prime} 33^{\prime} \mathrm{W}$, Viamão, RS (191) $30^{\circ} 12^{\prime} 08^{\prime} \mathrm{S}$ $50^{\circ} 12^{\prime} 52^{\prime} \mathrm{W}$, Balneário Pinhal, RS (215) $25^{\circ} 39^{\prime} 59^{\prime} \mathrm{S} 51^{\circ} 40^{\prime} 05^{\prime} \mathrm{W}$, Pinhão, PR (153091)25 $25^{\circ} 1^{\prime} 55^{\prime} \mathrm{S}$ $48^{\circ} 52^{\prime} 29^{\prime} \mathrm{W}$, Morretes, PR (156128 and 156129)

$26^{\circ} 36^{\prime} 54^{\prime} \mathrm{S} 51^{\circ} 04^{\prime} 18^{\prime} \mathrm{W}$, Calmon, PR (152033) $20^{\circ} 07^{\prime} 16^{\prime} \mathrm{S} 44^{\circ} 32^{\prime} 25^{\prime} \mathrm{W}$, Itaúna, MG (152658) $19^{\circ} 42^{\prime} 09^{\prime} \mathrm{S} 50^{\circ} 35^{\prime} 33^{\prime} \mathrm{W}$, Alexandrita, MG (152674) $19^{\circ} 04^{\prime} 13^{\prime} \mathrm{S} 43^{\circ} 24^{\prime} 58^{\prime} \mathrm{W}$, Conceição do Mato Dentro, MG (152654) $25^{\circ} 17^{\prime} 248^{\prime} \mathrm{S} 49^{\circ} 54^{\prime} 42^{\prime} \mathrm{W}$, Caçador, SC (152010) $29^{\circ} 54^{\prime} 18^{\prime} \mathrm{S} 50^{\circ} 06^{\prime} 15^{\prime} \mathrm{W}$, Imbé, RS (218)

$26^{\circ} 51^{\prime} 31^{\prime} \mathrm{S} 50^{\circ} 49^{\prime} 67^{\prime} \mathrm{W}$, Caçador, MG (152014) $25^{\circ} 17^{\prime} 48^{\prime} \mathrm{S} 49^{\circ} 54^{\prime} 42^{\prime} \mathrm{W}$, Tibagi, PR (152096) 
Table 1. (continued)

\begin{tabular}{|c|c|c|c|c|}
\hline Species & $2 n$ & Total length $(\mu \mathrm{m})$ & $\mathrm{L} / \mathrm{S}(\mu \mathrm{m})^{\mathrm{C}}$ & Coordinates, localities (voucher number) \\
\hline 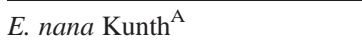 & 20 & 18.06 & $2.8-1.2$ & $25^{\circ} 38^{\prime} 37^{\prime} \mathrm{S} 51^{\circ} 40^{\prime} 01^{\prime} \mathrm{W}$, Pinhão, PR (158383) \\
\hline E. loefgreniana Boeck. $^{\mathrm{A}}$ & 20 & 16.84 & $2.0-1.4$ & $19^{\circ} 13^{\prime} 20^{\prime} \mathrm{S} 43^{\circ} 33^{\prime} 32^{\prime} \mathrm{W}$, Serra do Cipó, MG (152659) \\
\hline Eleocharis sp. $1^{\mathrm{A}}$ & 40 & 34.98 & $2.1-1.3$ & $\begin{array}{l}20^{\circ} 05^{\prime} 57^{\prime} \mathrm{S} 51^{\circ} 09^{\prime} 33^{\prime} \mathrm{W}, \text { Aparecida do Taboado, MS } \\
(151987) 19^{\circ} 10^{\prime} 55^{\prime} \mathrm{S} 57^{\circ} 42^{\prime} 47^{\prime} \mathrm{W} \text {, Pantanal, MS } \\
(153095) 20^{\circ} 38^{\prime} 42^{\prime} \mathrm{S} 46^{\circ} 21^{\prime} 24^{\prime} \mathrm{W} \text {, Furnas, MG } \\
(158459)\end{array}$ \\
\hline \multirow[t]{2}{*}{ E. niederleinii Boeck. ${ }^{\mathrm{A}}$} & 20 & 13.86 & $1.6-1.7$ & $\begin{array}{c}25^{\circ} 38^{\prime} 37^{\prime} \mathrm{S} 51^{\circ} 40^{\prime} 01^{\prime} \mathrm{W} \text {, Pinhão, PR }(158380) 19^{\circ} 42^{\prime} 09^{\prime} \mathrm{S} \\
50^{\circ} 35^{\prime} 33^{\prime} \mathrm{W} \text {, Alexandrita, MG }(151975) 20^{\circ} 10^{\prime} 30^{\prime} \mathrm{S} \\
51^{\circ} 12^{\prime} 54^{\prime} \mathrm{W} \text {, Aparecida do Taboado, MS }(151991) \\
27^{\circ} 07^{\prime} 12^{\prime} \mathrm{S} 48^{\circ} 36^{\prime} 77^{\prime} \mathrm{W} \text {, Rio Lavadeiras, SC (1) } \\
30^{\circ} 06^{\prime} 18^{\prime} \mathrm{S} 50^{\circ} 44^{\prime} 33^{\prime} \mathrm{W} \text {, Viamão, RS (192) }\end{array}$ \\
\hline & 30 & 33.10 & $6.5-0.5$ & $\begin{array}{c}26^{\circ} 16^{\prime} 46^{\prime} \mathrm{S} 51^{\circ} 03^{\prime} 02^{\prime} \mathrm{W}, \text { Porto União, SC }(152027) \\
25^{\circ} 41^{\prime} 06^{\prime} \mathrm{S} 51^{\circ} 32^{\prime} 08^{\prime} \mathrm{W}, \text { Turvo, PR }(152032)\end{array}$ \\
\hline E. viridans Kük. ex Osten ${ }^{\mathrm{A}}$ & 20 & 17.88 & $2.2-1.3$ & $30^{\circ} 06^{\prime} 18^{\prime} \mathrm{S} 50^{\circ} 44^{\prime} 33^{\prime} \mathrm{W}$, Viamão, RS (153094) \\
\hline $\begin{array}{l}\text { E. montana (Kunth) } \\
\text { Roem. and Schult. }\end{array}$ & 40 & 41.19 & $2.9-1.3$ & 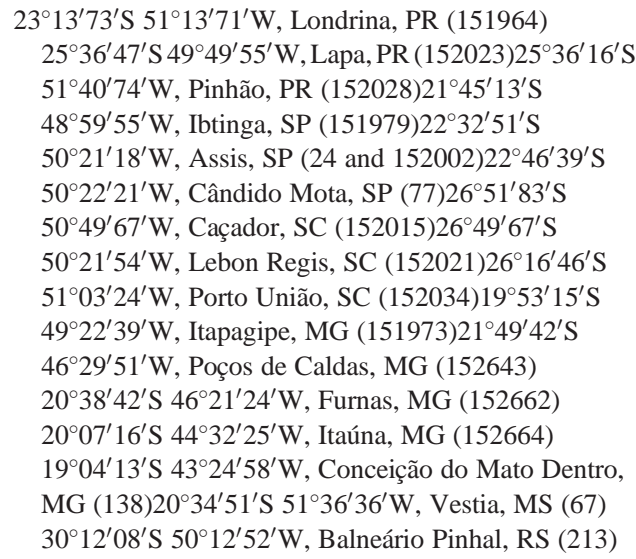 \\
\hline E. subarticulata (Nees) Boeck. & 6 & $19.10^{*}$ & $3.8-2.2$ & $\begin{array}{l}21^{\circ} 49^{\prime} 42^{\prime} \mathrm{S} 46^{\circ} 29^{\prime} 51^{\prime} \mathrm{W} \text {, Poços de Caldas, MG (152647) } \\
25^{\circ} 17^{\prime} 24^{\prime} \mathrm{S} 49^{\circ} 54^{\prime} 42^{\prime} \mathrm{W} \text {, Tibagi, PR (152031) } \\
24^{\circ} 32^{\prime} 16^{\prime} \mathrm{S} 49^{\circ} 57^{\prime} 11^{\prime} \mathrm{W} \text {, Piraí do Sul, PR (156093) } \\
25^{\circ} 35^{\prime} 17^{\prime} \mathrm{S} 51^{\circ} 33^{\prime} 34^{\prime} \mathrm{W} \text {, Pinhão, PR (156125) } \\
25^{\circ} 22^{\prime} 51^{\prime} \mathrm{S} 48^{\circ} 51^{\prime} 50^{\prime} \mathrm{W} \text {, Morretes, PR (156130) } \\
25^{\circ} 28^{\prime} 74^{\prime} \mathrm{S} 49^{\circ} 52^{\prime} 93^{\prime} \mathrm{W} \text {, São Luis do Purunã, PR (102) } \\
29^{\circ} 03^{\prime} 57^{\prime} \mathrm{S} 50^{\circ} 06^{\prime} 19^{\prime} \mathrm{W} \text {, Cambará do Sul, RS (236) } \\
28^{\circ} 45^{\prime} 05^{\prime} \mathrm{S} 50^{\circ} 22^{\prime} 09^{\prime} \mathrm{W} \text {, Cambará do Sul, RS (230) }\end{array}$ \\
\hline \multicolumn{5}{|l|}{$\begin{array}{l}\text { Subgenus Scirpidium } \\
\text { (Nees) Kukkonen }\end{array}$} \\
\hline Eleocharis sp. $2^{\mathrm{A}}$ & 10 & 8.47 & $1.9-1.5$ & $25^{\circ} 39^{\prime} 59^{\prime} \mathrm{S} 51^{\circ} 40^{\prime} 05^{\prime} \mathrm{W}$, Pinhão, PR (193) \\
\hline E. bonariensis $\mathrm{Nees}^{\mathrm{A}}$ & 20 & 20.20 & $2.5-1.6$ & $\begin{array}{c}28^{\circ} 45^{\prime} 05^{\prime} \mathrm{S} 50^{\circ} 22^{\prime} 09^{\prime} \mathrm{W} \text {, Cambará do Sul, RS (229) } \\
30^{\circ} 06^{\prime} 18^{\prime} \mathrm{S} 50^{\circ} 44^{\prime} 33^{\prime} \mathrm{W} \text {, Viamão, RS (189) }\end{array}$ \\
\hline
\end{tabular}


Table 1. (continued)

\begin{tabular}{|c|c|c|c|c|}
\hline Species & $2 n$ & Total length $(\mu \mathrm{m})$ & $\mathrm{L} / \mathrm{S}(\mu \mathrm{m})^{\mathrm{C}}$ & Coordinates, localities (voucher number) \\
\hline \multicolumn{5}{|l|}{$\begin{array}{l}\text { Subgenus Limnochloa } \\
\text { (P. Beauv. ex. Lestib.) Torr. }\end{array}$} \\
\hline E. interstincta (Vahl) Roem & 40 & 22.92 & $1.4-0.9$ & $08^{\circ} 39^{\prime} 40^{\prime} \mathrm{S} 35^{\circ} 09^{\prime} 57^{\prime} \mathrm{W}$, Rio Formoso, PE (11) \\
\hline and Schult. ${ }^{\mathrm{A}}$ & 52 & 23.58 & $1.1-0.7$ & $\begin{array}{l}25^{\circ} 48^{\prime} 28^{\prime} \mathrm{S} 48^{\circ} 33^{\prime} 11^{\prime} \mathrm{W}, \text { Matinhos, PR (158384) } \\
25^{\circ} 42^{\prime} 38^{\prime} \mathrm{S} 48^{\circ} 34^{\prime} 34^{\prime} \mathrm{W} \text {, Matinhos, PR (374) } \\
20^{\circ} 14^{\prime} 06^{\prime} \mathrm{S} 49^{\circ} 10^{\prime} 12^{\prime} \mathrm{W}, \text { Fronteira, MG (35) }\end{array}$ \\
\hline E. obtusetrigona (Lindl. and Nees) Steud. ${ }^{\mathrm{A}}$ & 52 & 24.40 & $1.1-0.7$ & $\begin{array}{c}19^{\circ} 4^{\prime} 13^{\prime} \mathrm{S} 43^{\circ} 24^{\prime} 58^{\prime} \mathrm{W} \text {, Conceição do Mato Dentro, MG } \\
(152655) 19^{\circ} 32^{\prime} 52^{\prime} \mathrm{S} 43^{\circ} 44^{\prime} 29^{\prime} \mathrm{W} \text {, Jaboticatubas, MG } \\
(119) 23^{\circ} 28^{\prime} 05^{\prime} \mathrm{S} 48^{\circ} 39^{\prime} 18^{\prime} \mathrm{W} \text {, Paranapanema, SP }(284) \\
25^{\circ} 36^{\prime} 16^{\prime} \mathrm{S} 51^{\circ} 40^{\prime} 74^{\prime} \mathrm{W} \text {, Pinhão, PR (354) }\end{array}$ \\
\hline E. liesneri S. González and Reznicek ${ }^{\mathrm{A}}$ & 50 & 24.24 & $1.3-0.7$ & $21^{\circ} 34^{\prime} 08^{\prime} \mathrm{S} 45^{\circ} 46^{\prime} 77^{\prime} \mathrm{W}$, Paraguaçu, MG (152648) \\
\hline E. plicarhachis (Griseb.) Svenson ${ }^{\mathrm{A}}$ & 54 & 30.64 & $1.5-0.9$ & $\begin{array}{l}19^{\circ} 10^{\prime} 55^{\prime} \mathrm{S} 57^{\circ} 42^{\prime} 47^{\prime} \mathrm{W} \text {, Pantanal, MS (180)20 } 20^{\circ} 10^{\prime} 30^{\prime} \mathrm{S} \\
51^{\circ} 12^{\prime} 54^{\prime} \mathrm{W} \text {, Aparecida do Taboado, MS (63) } \\
09^{\circ} 57^{\prime} 76^{\prime} \mathrm{S} 67^{\circ} 52^{\prime} 98^{\prime} \mathrm{W} \text {, Rio Branco, AC (158) }\end{array}$ \\
\hline E. acutangula (Roxb.) Schult. & 54 & 30.63 & $1.3-1.0$ & 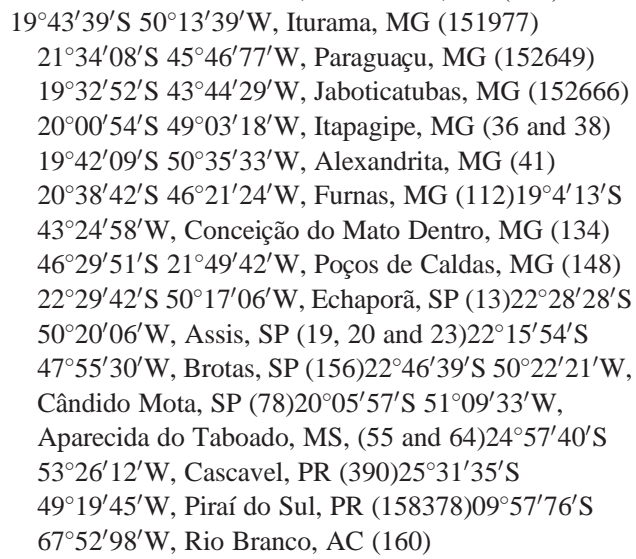 \\
\hline Eleocharis sp. $3^{\mathrm{A}}$ & 42 & 22.31 & $1.2-0.8$ & $08^{\circ} 39^{\prime} 40^{\prime} \mathrm{S} 35^{\circ} 09^{\prime} 57^{\prime} \mathrm{W}$, Rio Formoso, PE (12) \\
\hline E. laeviglumis $\mathrm{R}$. Trevis. and Boldrini ${ }^{\mathrm{A}}$ & 60 & 31.67 & $1.2-0.8$ & $29^{\circ} 54^{\prime} 18^{\prime} \mathrm{S} 50^{\circ} 06^{\prime} 15^{\prime} \mathrm{W}$, Imbé, RS (219) \\
\hline
\end{tabular}

*Total length diploid.

${ }^{\mathrm{A}}$ chromosome numbers recorded for the first time.

${ }^{B}$ the chromosomes numbers are reported for the first time.

${ }^{\mathrm{C}}$ larger chromosome/smaller chromosome. All samples were collected by CRM Da Silva and ALL Vanzela.

(Håkansson 1958; Strandhede 1965; Vanzela et al. 2000, 2003; Yano et al. 2004; Da Silva et al. 2008a; Hipp et al. 2009). In a smaller proportion, variation caused by multiple translocations and aneuploidy have been reported (Da Silva et al. 2005; Yano and Hoshino 2006b).

The more common mechanism of karyotype variation in Eleocharis appears to be polyploidy (Hoshino 1987; Yano et al. 2004; Da Silva et al. 2008a). The chromosome numbers described in the literature show a great variation, from $2 n=6$ (Da Silva et al. 2005) to $2 n=200$ (Roalson 2008). Further, some examples of intraspecific variation have been reported, such as $2 n=16,38,39,46,72-82$ in the Eleocharis palustris complex (Bureš et al. 2004). Yano et al. (2004) proposed a grouping of the Eleocharis species based in karyotype composition/organisation and molecular data. The first group was monophyletic and represented by karyotypes with small, symmetrical and numerous chromosomes $(<1.1 \mu \mathrm{m})$, which includes the subgenus Limnochloa (P. Beauv. ex T. Lestib.) Torr. The second group was paraphyletic and composed of species with larger chromosomes $(1.4-4.3 \mu \mathrm{m})$ and a gradient of size or bimodal karyotypes, which includes species of subgenus Eleocharis.

At least 60 species of Eleocharis occur in Brazil, with representatives of three of the four subgenera: Eleocharis, Scirpidium (Nees) Kukkonen and Limnochloa, only Zinserlingia T. V. Egorova not being present in the country (González-Elizondo and Tena-Flores 2000; Alves et al. 2009; Trevisan and Boldrini 2008). Eleocharis is a genus with a special importance in the Brazilian flora because of a great number of species that grow in wetland areas, some of them widely distributed and others endemic. In this study we analysed the karyotypes of 25 species of Eleocharis by mitosis and meiosis

Fig. 1. Conventional chromosome analysis showing metaphases and prometaphases in species of the section Eleogenus $(A-M)$ : $(A-D)$ Eleocharis maculosa with $2 n=10,8,7$ and 6, respectively; $(E)$ E. debilis with $2 n=30 ;(F)$ E. flavescens with $2 n=10 ;(G)$ E. capillacea with $2 n=10 ;(H-I)$ E. sellowiana with $2 n=10$ and 20 , respectively. Arrows indicate the nucleolar constrictions; $(J-K)$ E. geniculata with $2 n=10$ and 20 , respectively; (L) E. subarticulata with $2 n=6 ;(M)$ E. montana with $2 n=40$, and in the section Eleocharis. $(N-Q)$ : $(N-P)$ E. minima with $2 n=34,20$ and 30 , respectively; $(Q)$ E. niederleinii with $2 n=20$. Note the diffuse interphase nuclei without evident chromocenters in $C, M$ and $Q$ and with ones in $G$. Bar $=10 \mu \mathrm{m}$. 


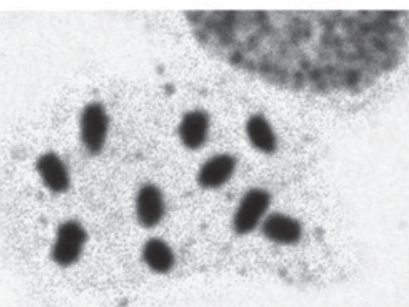

(A)
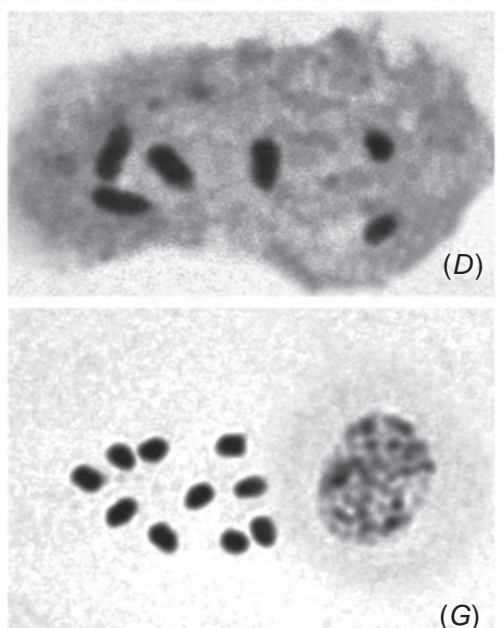

(G)
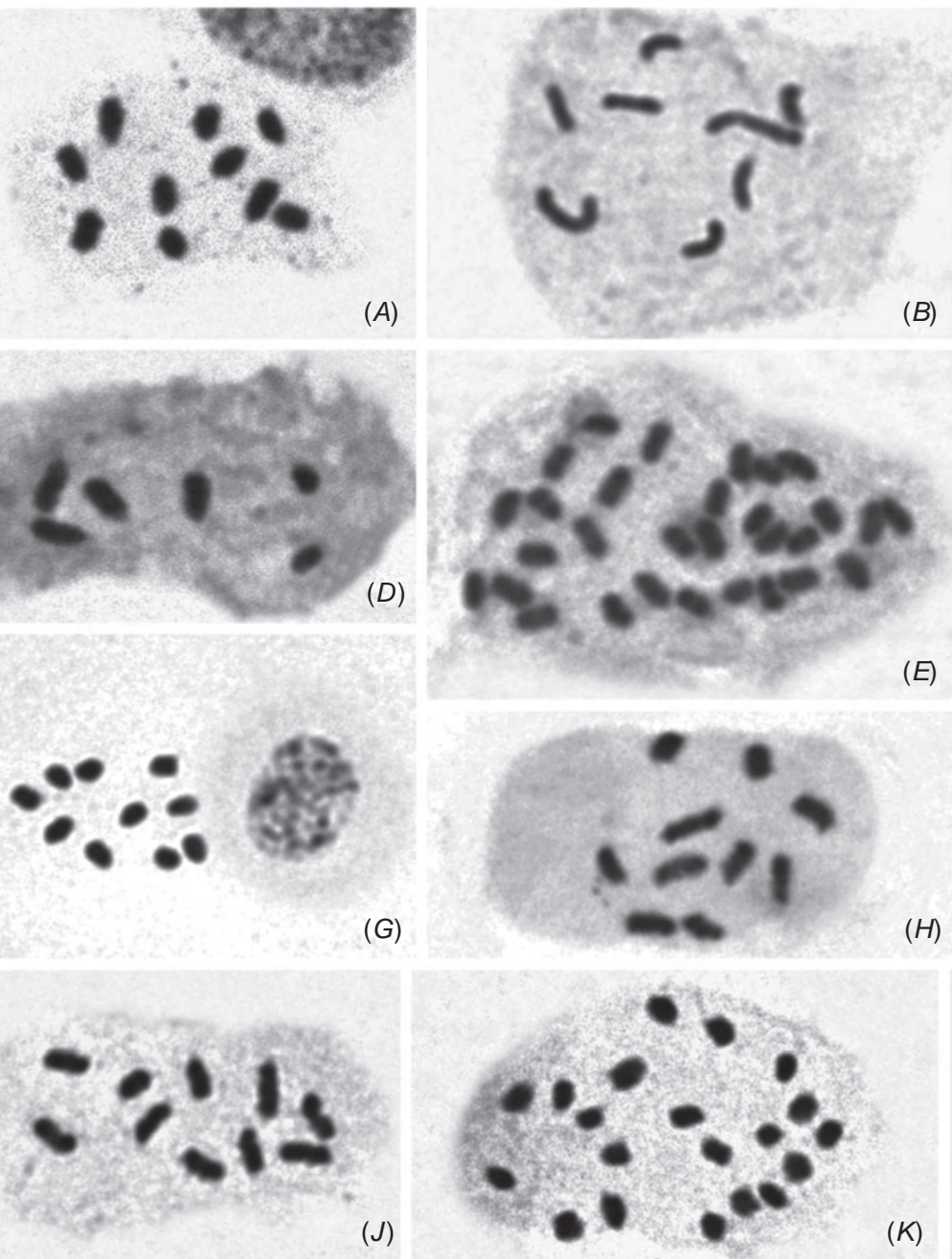

(B)

(E)

(H)

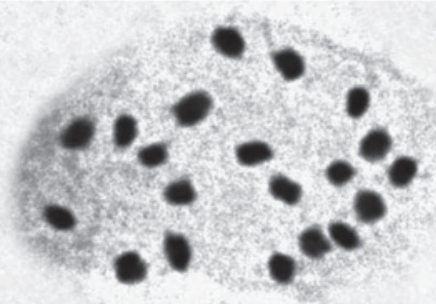

(K)
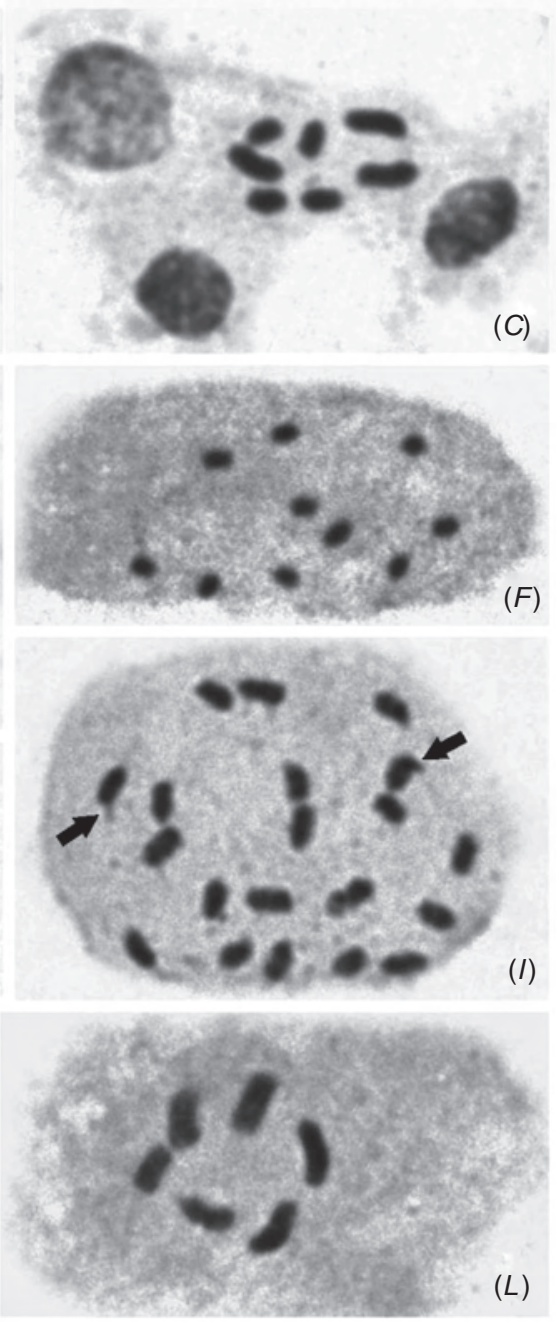
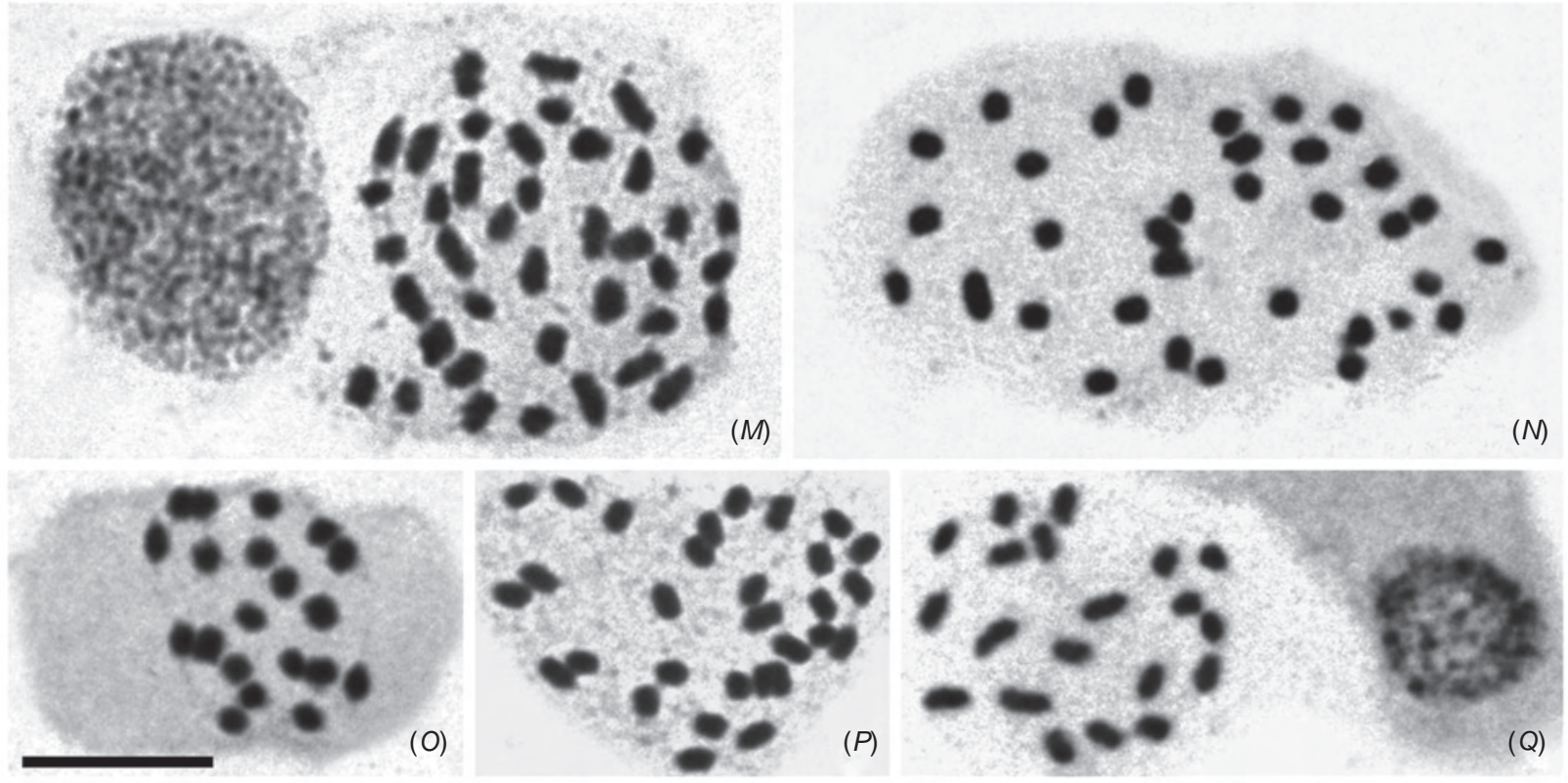

$(N)$ 

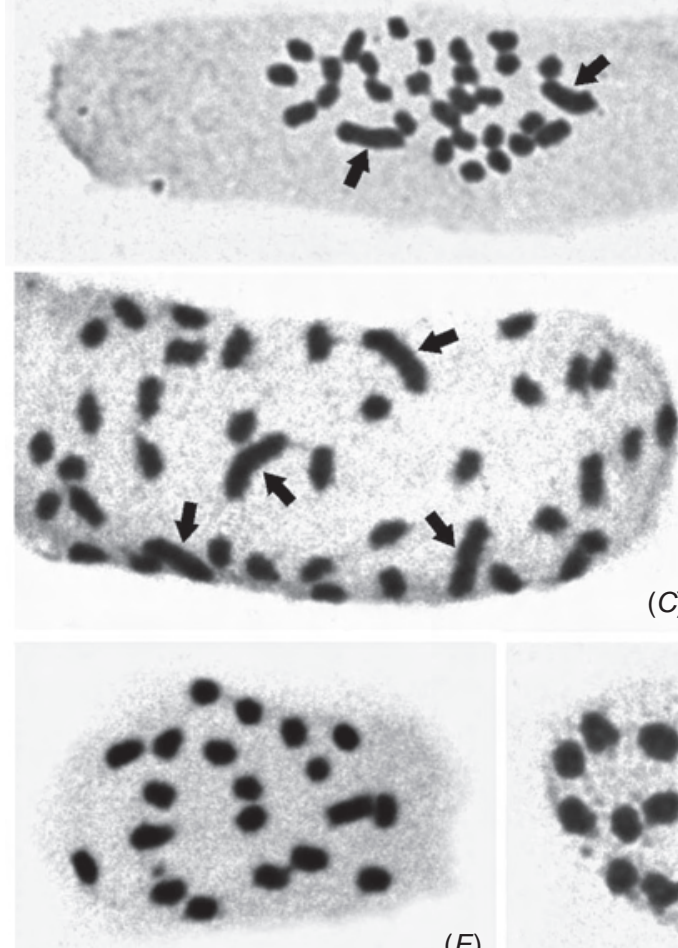

(A)

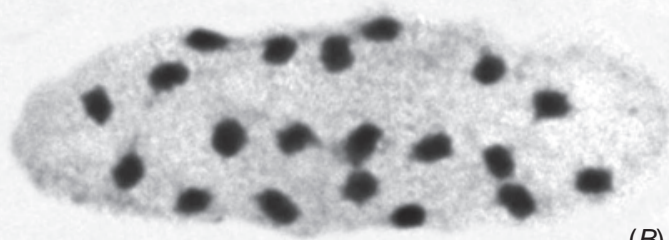

(B)

(C)
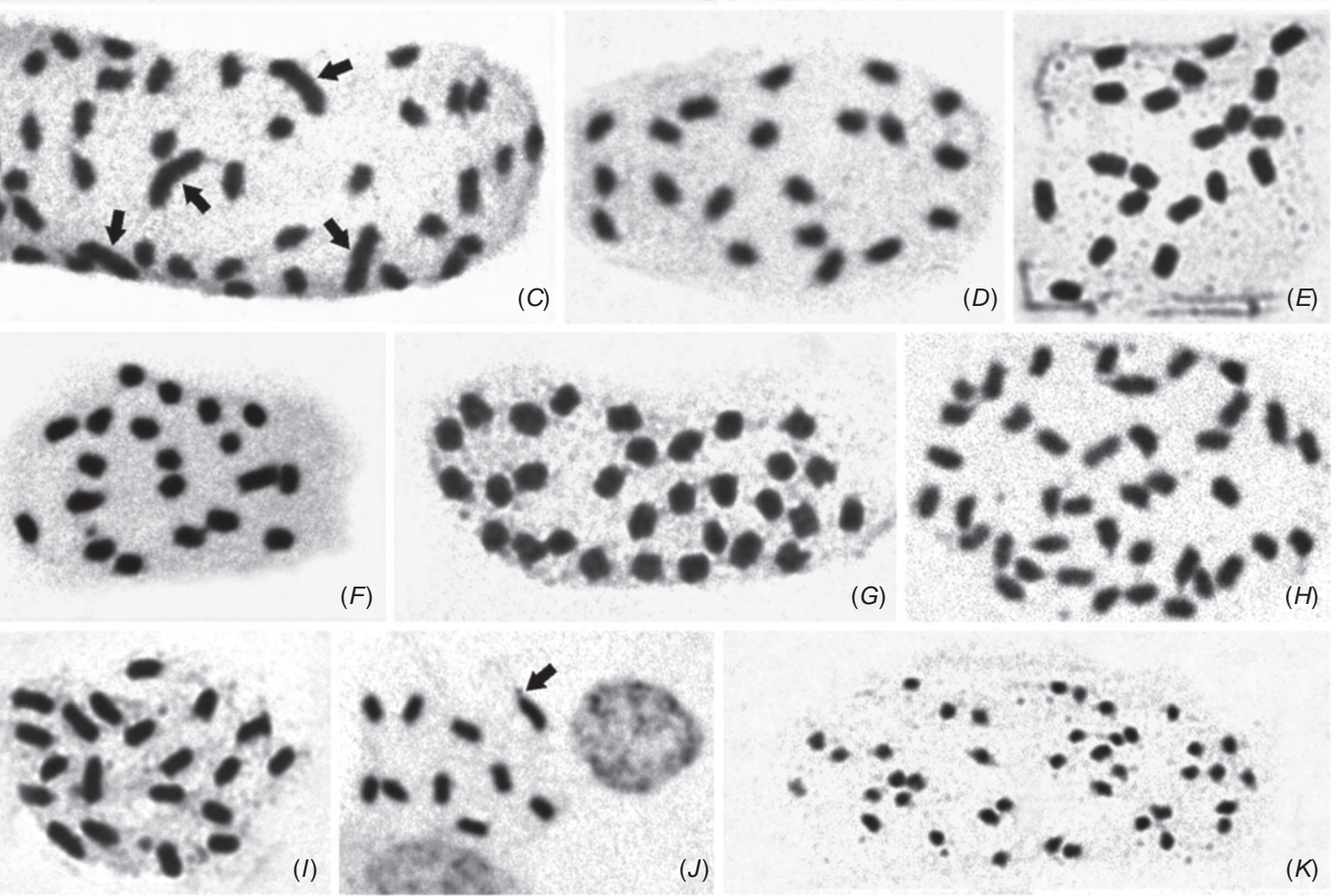

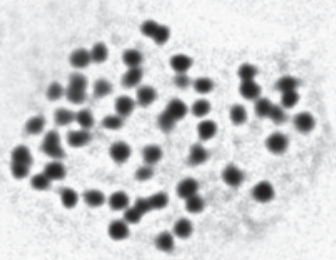

(L)

$\because 0 \%$

.

$6: 0^{\circ}: 0^{\circ}$

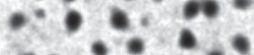

$\because \div:$

18.200
(J)

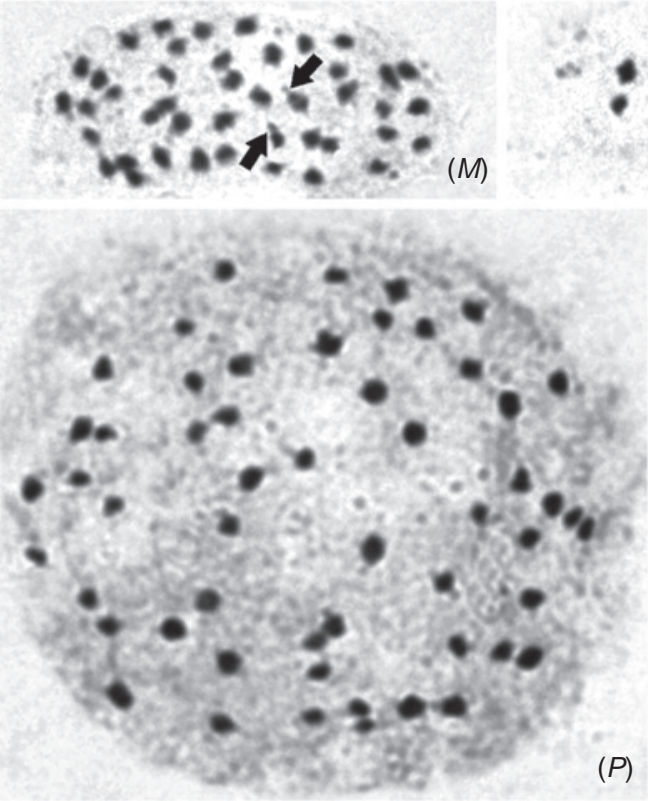

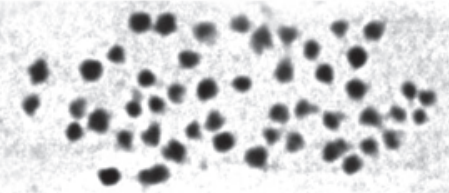
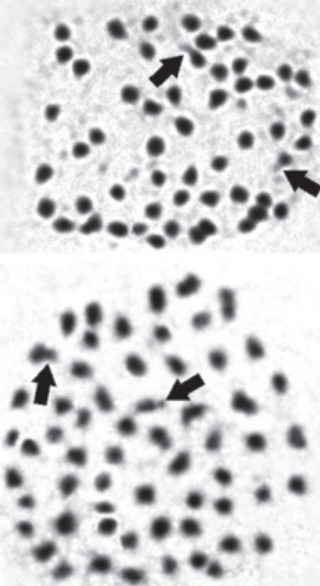
with the aim to compare the karyotype structure and evolution, as well as the usefulness of such information to the taxonomy of Eleocharis.

\section{Materials and methods}

For this study 147 populations of 25 species, with at least three specimens of each population, were collected in 10 Brazilian states. Samples were cultivated in the greenhouse of the Laboratório de Biodiversidade e Restauração de Ecossistemas (LABRE) at Universidade Estadual de Londrina, Paraná, Brazil. Vouchers were deposited at the ICN herbarium of the Universidade Federal do Rio Grande do Sul, Porto Alegre, Brazil (Table 1).

The karyotypical analyses were performed with root tips pretreated in $2 \mathrm{mM}$ 8-hydroxyquinoline for $24 \mathrm{~h}$, fixed in ethanol : acetic acid $(3: 1, \mathrm{v}: \mathrm{v})$ for $24 \mathrm{~h}$, and stored at $-20^{\circ} \mathrm{C}$ or immediately used. Samples were washed in distilled water, softened in $4 \%$ cellulase plus $40 \%$ pectinase $(\mathrm{w}: \mathrm{v})$ at $37^{\circ} \mathrm{C}$ for $3 \mathrm{~h}$, hydrolysed in $1 \mathrm{M} \mathrm{HCl}$ for $10 \mathrm{~min}$ at $60^{\circ} \mathrm{C}$, washed again in distilled water, and squashed in a drop of $45 \%$ acetic acid. Slides were stained in $2 \%$ Giemsa and mounted with Entellan. The chromosome counts were made in at least 20 cells for each sample. The chromosome size and the haploid/diploid set length were measured from at least 10 metaphase cells with similar condensation, with the MicroMeasure 3.3 software (www.colostate.edu/Depts/Biology/MicroMeasure) and the data used to assemble idiograms.

For the meiotic study, spikelets of at least one species of each section were dissected and the anthers directly fixed in absolute ethanol: acetic acid (3:1, v:v) for $12 \mathrm{~h}$, and kept at $-20^{\circ} \mathrm{C}$ until used. Anthers were hydrolysed in $1 \mathrm{M} \mathrm{HCl}$ at $60^{\circ} \mathrm{C}$ for $9 \mathrm{~min}$, washed in distilled water and squashed in a drop of $45 \%$ acetic acid. The coverslips were removed after freezing in liquid nitrogen, stained with $2 \%$ Giemsa and the slides mounted with Entellan. All images were acquired with a Leica DM 4500 B microscope equipped with a DFC 300FX camera and Leica IM50 4.0 software.

\section{Results and discussion}

The chromosome number of 147 populations of 25 species, including representatives of all the subgenera of Brazilian Eleocharis (Table 1) was analysed. None of the species studied presented primary constrictions in the chromosomes and only terminal nucleolar constrictions (satellites) were visualised (Figs $1 I, 2 J, M, Q, R$ ), as reported for other species of Eleocharis, as well as other Cyperaceae (Hoshino 1987; Luceño et al. 1998; Yano and Hoshino 2007; Da Silva et al. $2008 a$ ). For 17 species, the chromosome numbers are reported for the first time. These varied from $2 n=10$ in E. capillacea Kunth to $2 n=60$ in E. laeviglumis R. Trevis. and Boldrini. In the other eight species previously reported numbers were confirmed (Table 1). Of the more than 200 species of Eleocharis known worldwide, less than $25 \%$ have their karyotypes described (Davies 1956; Strandhede 1964, 1965; Harms 1968; Nijalingappa 1972, 1973; Sanyal and Sharma 1972; Schuyler 1977; Löve and Löve 1981; Hoshino 1987; Hoshino et al. 2000; Yano et al. 2004; Da Silva et al. 2005, 2008b; Yano and Hoshino 2006b; Roalson 2008). As for Brazil, of the 63 species listed at present (Alves et al. 2009), the chromosome numbers of 12 were previously described, $2 n=20$ in E. geniculata (Pedrosa et al. 1999) and six different numbers for 11 species: $2 n=6,10,12,20,40$ and 54 (Da Silva et al. 2008a).

Of $~ 5000$ species in the family Cyperaceae (Goetghebeur 1998), only $16 \%$ have the chromosome number known, and half of these numbers have been described for species of Carex L. (Roalson 2008). Although there is a 'gap' in the knowledge of the patterns and processes of chromosomal evolution in this family (Hipp et al. 2009), the literature indicates that the karyotype differentiation process varies among groups. In Carex, agmatoploidy and symploidy are considerably more frequent (Hipp et al. 2009) when compared with other genera such as Rhynchospora Vahl (Luceño et al. 1998; Vanzela et al. 2000), Scleria P.J. Bergius (Yano and Hoshino 2007) and Eleocharis (Yano et al. 2004; Da Silva et al. 2008a). In this context, we cannot discard the possible existence of some genetic control that favours the agmatoploidy and/or symploidy in different species. However, the lack of studies involving a larger number of populations contributes to this gap in the knowledge of chromosomal evolution in Cyperaceae. Cytogenetic studies in several populations of one species, like those in Carex laevigata Smith (Luceño and Castroviejo 1991), Carex conica Boott (Hoshino and Waterway 1994), Carex blepharicarpa Franch. (Hoshino and Okamura 1994), Carex sociata Boott (Ohkawa et al. 2000), Eleocharis palustris (L.) Roem. and Schult. (Bureš et al. 2004) and Eleocharis maculosa (Vahl) Roem and Schult. Da Silva et al. (2008b) show that an increase in intraspecific sampling can reveal chromosome changes that are not detected in smaller samples, which can be important in understanding karyotype evolution of these groups.

\section{Subgenus Eleocharis}

Of the 25 studied species, 16 belong to the subgenus Eleocharis, representing two of the three sections recognised by GonzálezElizondo and Peterson (1997): Eleogenus (Nees) Benth. and Hook. F. and Eleocharis. In section Eleogenus, six species were studied. The chromosome numbers varied from $2 n=6$ in Eleocharis maculosa, which also exhibited populations with $2 n=10,8$ and 7 (Fig. $1 A-D$ ), as previously reported by Da Silva et al. (2008b), to $2 n=30$ in Eleocharis debilis Kunth (Fig. 1E). Eleocharis flavescens (Poir.) Urb. and E. capillacea Kunth

Fig. 2. Conventional chromosome analysis showing metaphases in species of the section Eleocharis. $(A-H)$ : $(A)$ E. niederleinii with $2 n=30$. Arrows point out two larger chromosomes; $(B-C) E$. viridans with $2 n=20$ and 40 . Arrows indicate four larger chromosomes. $(D-F)$ E. loefgreniana, E. contracta and E. nana, all with $2 n=20$. $(G)$ E. filiculmis with $2 n=30,(H)$ Eleocharis sp. 1 with $2 n=40$, and in the subgenus Scirpidium. $(I-J):$ E. bonariensis with $2 n=20$ and Eleocharis sp. 2 with $2 n=10$, respectively. Arrows point out nucleolar constrictions. Conventional chromosome analysis in species of subgenus Limnochloa. $(K-R)$ : $(K-L)$ Eleocharis interstincta with $2 n=40$ and 52, respectively; $(M)$ Eleocharis sp. 3 with $2 n=42 ;(N)$ E. liesneri with $2 n=50$; $(O)$ E. obtusetrigona with $2 n=52 ;(P)$ E. plicarhachis with $2 n=54 ;(Q)$ E. acutangula with $2 n=54$ and $(R)$ E. laeviglumis with $2 n=60$. Arrows point out nucleolar constrictions. $\mathrm{Bar}=10 \mu \mathrm{m}$. 


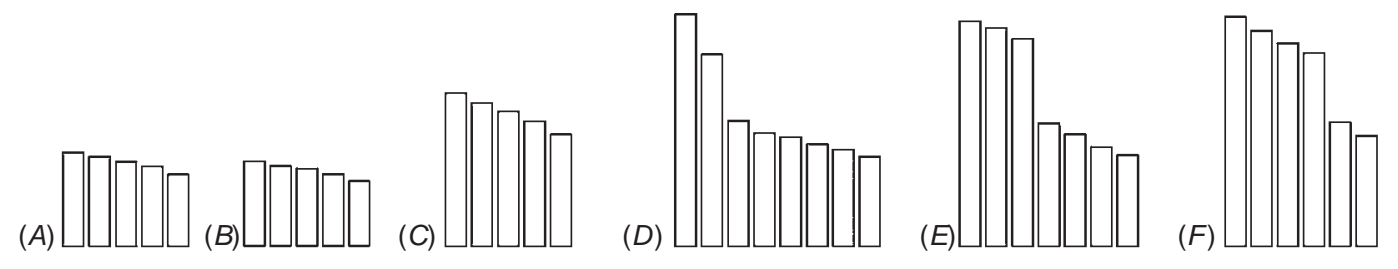

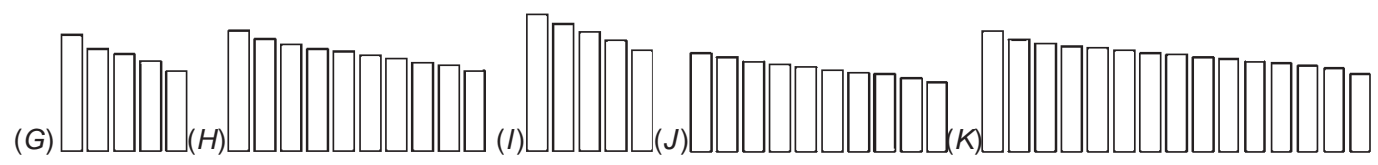
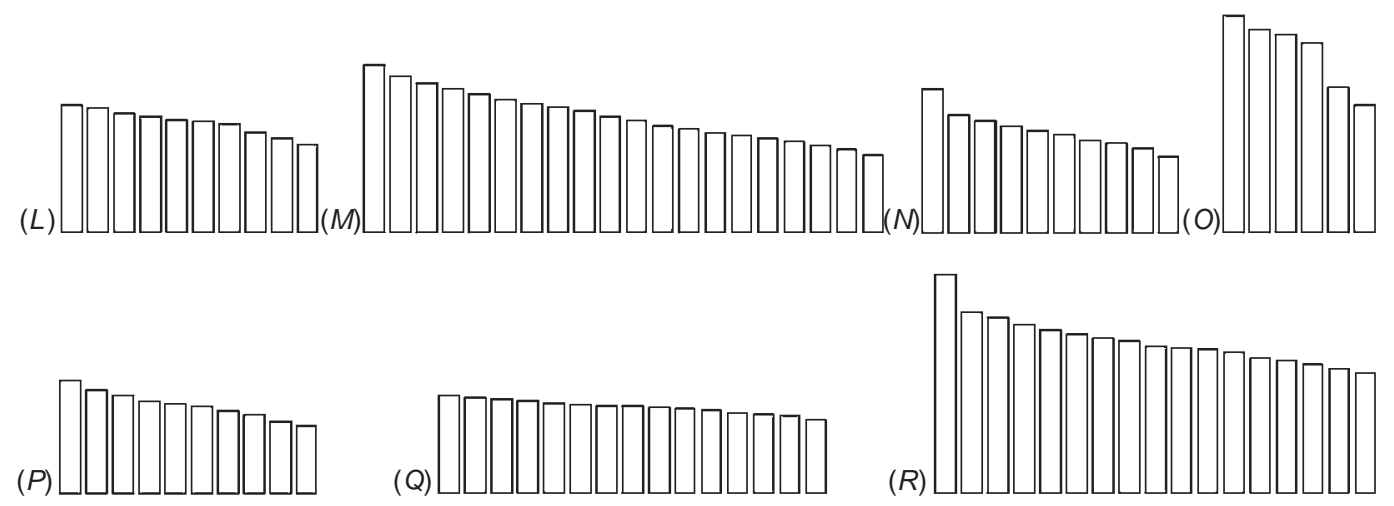

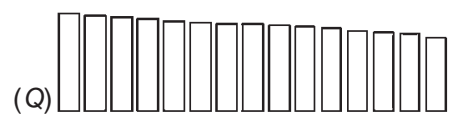
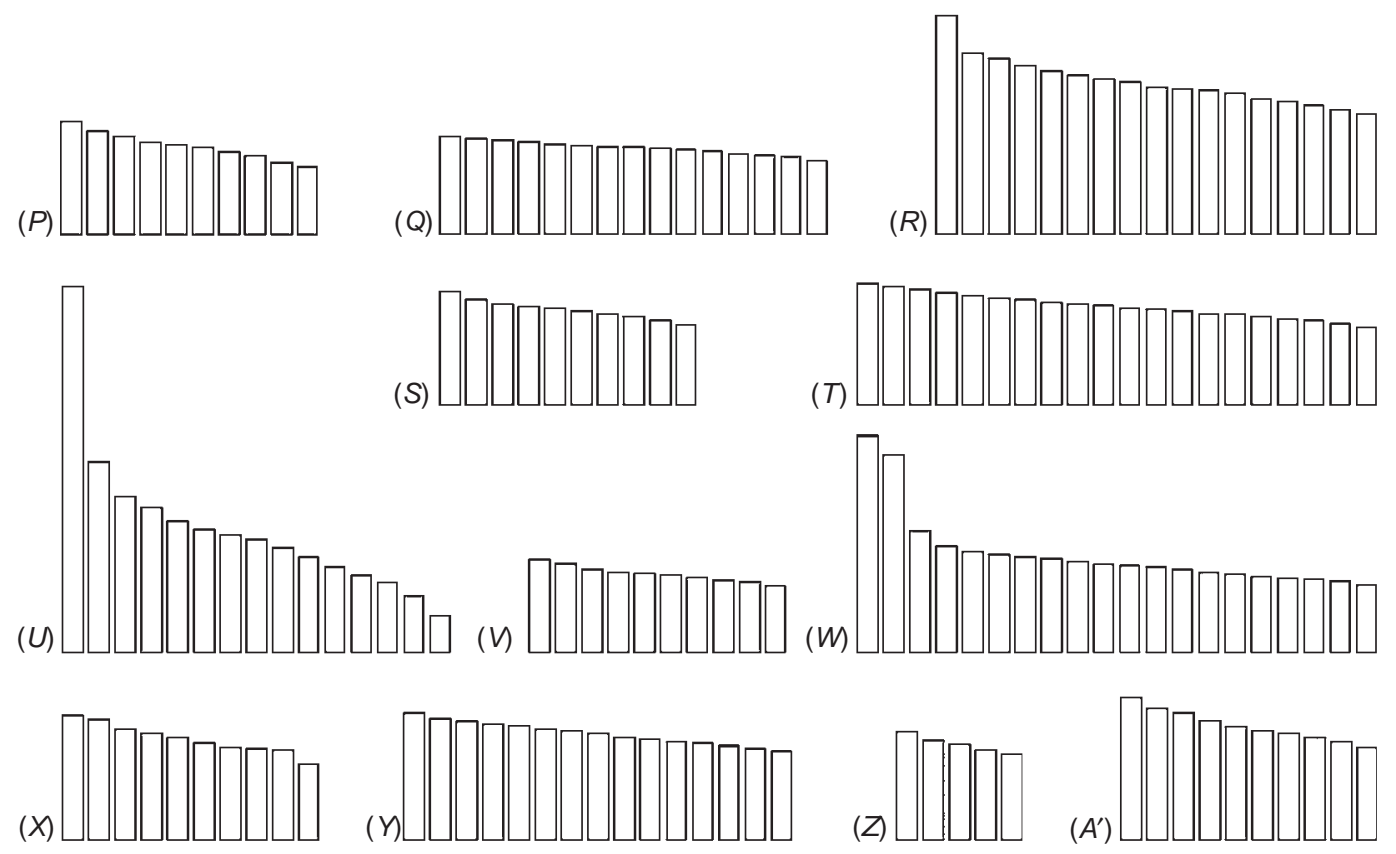

(8)

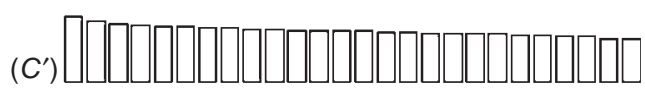

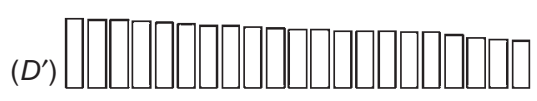

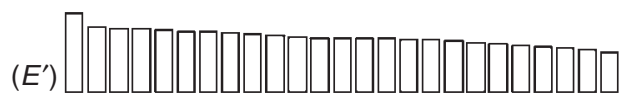

(ต)

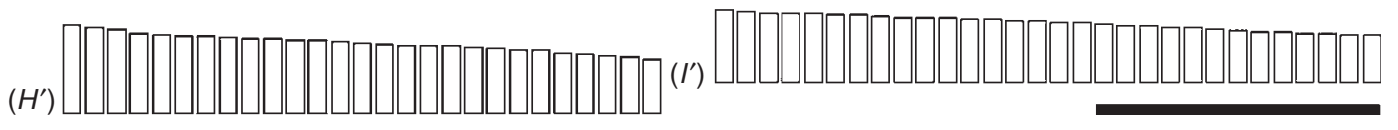


showed $2 n=10$ (Fig. $1 F, G$ ). The other two species, Eleocharis sellowiana Kunth and E. geniculata (L.) Roem and Schult., also have intraspecific variation with two chromosome numbers, both with $2 n=10$ and 20 (Fig $1 H-K$ ).

In section Eleocharis, chromosome numbers varied from $2 n=6$ in E. subarticulata (Nees) Boeck. (Fig. $1 L$ ) to $2 n=40$ in E. montana (Kunth) Roem. and Schult. (Fig. 1M). Eleocharis minima (Vahl) Roem. and Schult. was the only species that showed three numbers with $2 n=20,30$ and 34 (Fig. $1 N-P$ ). Other species also presented multiple numbers, as E. niederleinii Boeck. with $2 n=20$ and 30 (Figs $1 Q, 2 A$ ) and E. viridans Kük. ex Osten with $2 n=20$ and 40 (Fig. $2 B, C$ ). For the remaining species the numbers were $2 n=20$ in E. loefgreniana Boeck., E. contracta Maury, and E. nana Kunth (Fig. $2 D-F$ ), $2 n=30$ in E. filiculmis Kunth (Fig. $2 G$ ), and $2 n=40$ (Fig. $2 H$ ) in one species related to E. loefgreniana but with very proliferous spikelets, named here as Eleocharis sp. 1. Proliferous spikelets, producing new culms instead of flowers, are not characteristic of E. loefgreniana and these samples could belong to an undescribed taxon.

The chromosome measurements revealed that all the species of subgenus Eleocharis have karyotypes with chromosomes decreasing gradually in size (Fig. 3). Eleocharis niederleinii with $2 n=30$ (Fig. $3 U$ ) showed two chromosomes $\sim 6.5 \mu \mathrm{m}$ in length, and E. viridans with $2 n=40$ (Fig. $3 W$ ) four chromosomes varying from $3.8 \mu \mathrm{m}$ to $2.2 \mu \mathrm{m}$ (Table 1, Fig. 3). These bigger chromosomes could have been originated by chromosome fusion or symploidy (which is a type of disploidy). This rearrangement seems to be common in other species of section Eleocharis, such as E. palustris (L.) Roem. and Schult., E. uniglumis (Link) Schult. and E. mamillata H. Lindb. (Strandhede 1965), but was better documented in E. maculosa, which is a member of the section Eleogenus (Da Silva et al. 2008b). However, our data do not allow us to identify, in this case, the chromosomes that participated in these fusions in the process of disploidy. In another case, Yano and Hoshino (2006b) reported the occurrence of aneuploidy in Eleocharis kamtschatica (C.A. Mey.) Kom. based in chromosome length differences, but these authors do not show the nondisjunction process or the irregular meiosis to confirm the aneuploidy process.

The representatives of the sections Eleogenus and Eleocharis from Brazil share common cytogenetic features including: (i) chromosome reduction to $2 n=6$ starting from $x=5$; (ii) polyploidy in $\sim 80 \%$ of the species; (iii) occurrence of intraspecific variation in chromosome number; (iv) chromosome length around $2.2 \mu \mathrm{m}$, except for E. niederleinii and E. viridans; and (v) $\sim 20.42 \mu \mathrm{m}$ of haploid total length. Similarly, other species of subgenus Eleocharis that occur in other continents show similar karyotype variation as presented here (Håkansson 1958; Strandhede 1965; Nijalingappa 1973; Bureš et al. 2004; Yano et al. 2004; Roalson 2008). The diversity of karyotypes found in Eleocharis subgenus Eleocharis is mirrored by the tremendous morphological diversity in the group, many of whose subdivisions are para- or polyphyletic (Roalson and Friar 2000).

\section{Subgenus Scirpidium}

Only two species of subgenus Scirpidium were analysed, E. bonariensis Nees with $2 n=20$ (Fig. 2I) and Eleocharis sp. 2 with $2 n=10$ (Fig. $2 J$ ), a species closely related to $E$. radicans (Poir.) Kunth, which was also recorded with $2 n=10$ (Da Silva et al. 2008a). Eleocharis sp. 2 differs from E. radicans by having capillary culms, spikelets 15-30-flowered and smaller achenes, being probably a new taxon for the subgenus. Besides E. radicans, there are few cytogenetical data for species of Scirpidium in the literature, with records for only two additional species, E. acicularis (L.) Roem. and Schult. with $2 n=56,20$ and E. atricha R.Br. with $2 n=10$ (Roalson 2008).

In spite of the low number of studied species, the intraspecific variation in E. acicularis and the chromosomes gradually decreasing in size that have been found, allow us to suggest that the karyotypes of Scirpidium and Eleocharis have greater similarity to each other than either is to karyotypes of subgenus Limnochloa. This conclusion corroborates the results of the phylogenetic studies of Roalson and Friar (2000) and Roalson and Hinchliff (2007). The morphological evidence also indicates that Scirpidium, although a well-delimitated group with species sharing a particular ornamentation of the achenes (with longitudinal rows of fine trabeculae), is more closely related to the subgenus Eleocharis than to Limnochloa.

\section{Subgenus Limnochloa}

All the species of subgenus Limnochloa exhibited karyotypes with many and small chromosomes. Eleocharis interstincta (Vahl) Roem. and Schult. presented $2 n=40$ and 52, being 40 the lowest found to this subgenus (Fig. $2 K, L$ ). Interestingly, we found $2 n=42$ (Fig. $2 M$ ) in a species (named here as Eleocharis sp. 3), perhaps related to E. interstincta due to the presence of hollow and septate culms, but with an evident central vascular bundle along the culm. Since the septate culms have multiple origins in Limnochloa (Roalson and Hinchliff 2007) the relations between Eleocharis sp. 3 and $E$. interstincta need to be explored with other studies. The other numbers found in Limnochloa were $2 n=50$ in E. liesneri S. González and Reznicek (Fig. $2 N$ ), $2 n=52$ in E. obtusetrigona (Lindl. and Nees) Steud. (Fig. 2O), $2 n=54$ in E. plicarhachis (Griseb.) Svenson and (Fig. $2 P$ ) and E. acutangula (Roxb.) Schult. (Fig. $2 Q$ ), and $2 n=60$ in E. laeviglumis R. Trevis. and

Fig. 3. Idiograms of the studied species. Note that all species exhibited chromosomes decreasing gradually in size, independent of chromosome numbers. All the idiograms represent the haploid set, except $D-F$ and $O$, which indicate the diploid set. $(A-K)$ Species of the section Eleogenus, being E. flavescens $(A)$; E. capillacea $(B) ; E$. maculosa with $2 n=10(C), 2 n=8(D), 2 n=7(E)$ and $2 n=6(F) ;$ E. sellowiana $2 n=10(G)$ and $20(H) ; E$. geniculata with $2 n=10(I)$ and $20(J)$; E. debilis $(K)$. Species of the section Eleocharis $(L-Y)$, being: E. contracta $(L) ;$ E. montana $(M) ;$ E. nana $(N) ;$ E. subarticulata $(O) ; E$. minima with $2 n=20(P), 30(Q)$ and $34(R)$; E. loefgreniana $(S)$; Eleocharis sp. $1(T) ;$ E. niederleinii with $2 n=30(U)$ and $20(V) ; E$. viridans with $2 n=40(W)$ and $20(X)$, and E. filiculmis $(Y)$. Species of the subgenus Scirpidium $\left(Z, A^{\prime}\right)$, being: Eleocharis sp. $2(Z)$ and E. bonariensis $\left(A^{\prime}\right)$. Species of the subgenus Limnochloa $\left(B^{\prime}-I^{\prime}\right)$, being: E. interstincta with $2 n=40\left(B^{\prime}\right)$ and $52\left(C^{\prime}\right)$; Eleocharis sp. $3\left(D^{\prime}\right)$; E. liesneri $\left(E^{\prime}\right)$; E. obtusetrigona $\left(F^{\prime}\right) ;$ E. acutangula $\left(G^{\prime}\right) ;$ E. plicarhachis $\left(H^{\prime}\right)$ and E. laeviglumis $\left(I^{\prime}\right)$. Bar $=5 \mu \mathrm{m}$. 
Boldrini (Fig. 2R). Of all these records, only E. acutangula had been previously studied showing always $2 n=54$ (Nijalingappa 1972; Rath and Patnaik 1978; Hoshino 1987; Da Silva et al. 2008a). The higher chromosome numbers found in Eleocharis worldwide belong to species of Limnochloa, as in Eleocharis kuroguwai Ohwi with $2 n=\sim 196$
(Hoshino 1987), E. ochrostachys Steud. with $2 n=74$ (Yano et al. 2004), and E. dulcis (Burm.f.) Trin. ex Hensch. with $2 n=200$ and 172 (Roalson 2008).

Our cytogenetical analyses confirm that the species of Limnochloa are separated from the rest of the genus by their numerous, small chromosomes $(<1.4 \mu \mathrm{m})$, although the

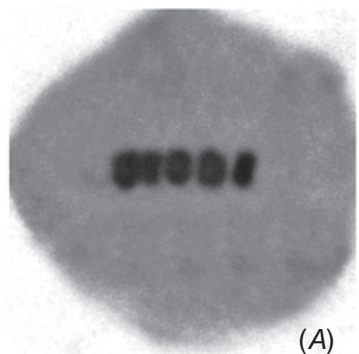

(A)

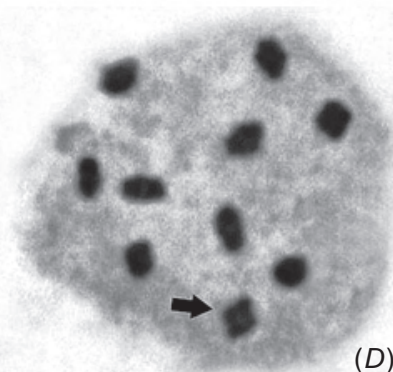

(D)

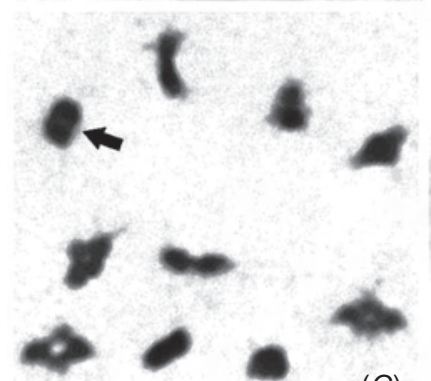

(G)

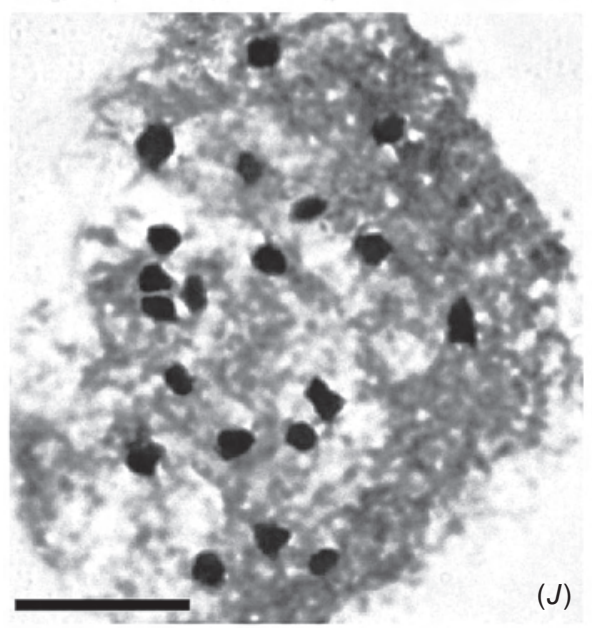

$(J)$

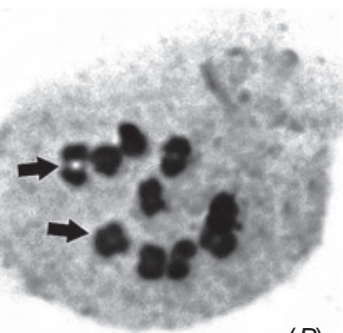

(B)

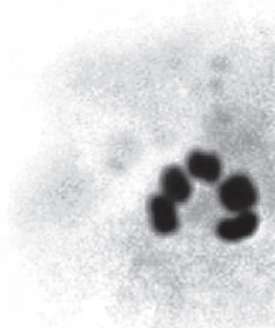

(C)

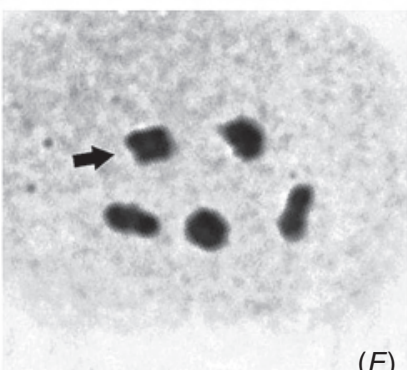

$($ (E)

$(F)$

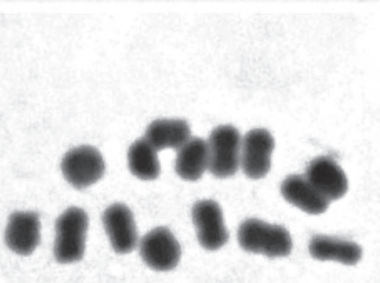

$(l)$

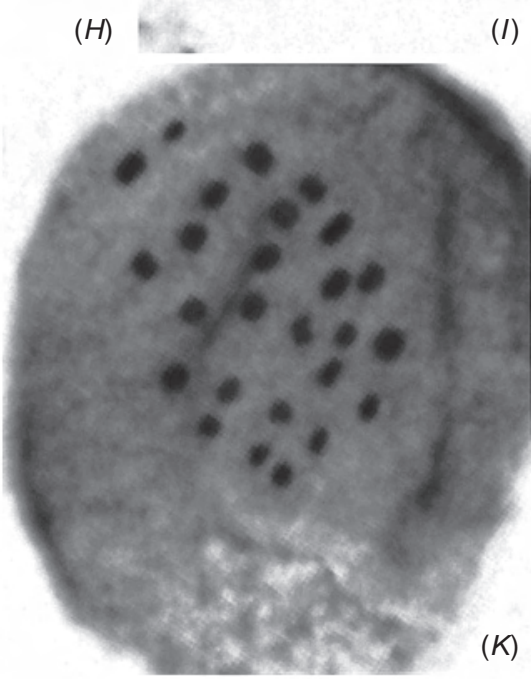

Fig. 4. Meiotic analysis in species of Eleocharis: $(A, B)$ metaphase I of E. geniculata with $5^{\mathrm{II}}$ and $10^{\mathrm{II}}$, respectively; $(C, D)$ metaphase I of E. sellowiana with $5^{\mathrm{II}}$ and $10^{\mathrm{II}}$, respectively; $(E, F)$ metaphase I of E. flavescens and E. capillacea, both with $5^{\mathrm{II}} ;(G)$ diakinesis in $E$. nana with $10^{\mathrm{II}}$; $(H)$ metaphase I of E. bonariensis with $10^{\mathrm{II}} ;(I)$ metaphase I of E. filiculmis with $15^{\mathrm{II}} ;(J)$ metaphase I of E. montana with $20^{\mathrm{II}}$ and $(K)$ metaphase I of $E$. interstincta with $26^{\mathrm{II}}$. Arrows point out the 'Box' arrangement of bivalents. Bar $=10 \mu \mathrm{m}$. 
karyotypes do have chromosomes decreasing gradually in size as in the other species of the genus (see Table 1 and Fig. 3). The haploid set genome size of Limnochloa species seems not to exceed the sizes of those of other subgenera with lower chromosome numbers (Table 1). According to Yano et al. (2004), the karyotypes of Limnochloa can have been derived from others with $2 n=10$ and 20 . Our results do not permit us to support or confirm the proposal of Yano and colleagues, but it seems clear that the karyotype differences among Limnochloa and the other subgenera corroborate the separation of Limnochloa as a group based on morphological features (Kukkonen 1990; González-Elizondo and Peterson 1997) and molecular data (Roalson and Friar 2000).

\section{Meiotic analyses and polyploidy}

The majority of the studied species presented chromosome numbers multiple of $x=5$. Eleocharis geniculata, E. sellowiana, E. flavescens and E. capillacea, all belonging to section Eleogenus and all with $2 n=10$, show regular meiosis with five bivalents (Fig. $4 A, C, E, F$ ). The first two species presented also polyploid populations with $2 n=20$, but the regular meiosis with bivalent formation was also confirmed (Fig. 4B, D, respectively). In other species with chromosome numbers larger than $2 n=10$, such as E. nana with $2 n=20$ (Fig. $4 G$ ), E. bonariensis with $2 n=20$ (Fig. $4 H$ ), E. filiculmis with $2 n=30$ (Fig. 4I), E. montana with $2 n=40$ (Fig. $4 J$ ) and E. interstincta with $2 n=52$ (Fig. $4 K$ ), only bivalents were observed. Additionally, some bivalents exhibited a 'box' shape, as in E. geniculata (Fig. 4B), E. sellowiana (Fig. 4D), E. flavescens (Fig. 4E), E. capillacea (Fig. 4F) and E. nana (Fig. 4G), which are characteristic of holocentric chromosomes (Strandhede 1965; Vanzela et al. 2000).

Our study showed 80\% polyploidy in Brazilian Eleocharis, with bivalent associations in both diploids and polyploids. As the bivalent or multivalent associations may depend on the neopolyploid or paleopolyploid condition (Grant 1971; Otto 2007), as well as of gene control (Evans 1988; Griffiths et al. 2006; Bozza and Pawlowski 2008), our results do not allow us to determine if the chromosome numbers were doubled by auto- or allopolyploidy. Some multivalent associations have been associated with natural allopolyploids, as in the E. palustris complex, E. uniglumis and E. mamillata (Strandhede 1965) and in hybrids of Carex (Luceño 1993). Similarly, multivalent associations have been found in some autopolyploids, as in Fimbristylis falcata (Vahl) Kunth (Nijalingappa 1977), Carex siderosticta Hance (Tanaka 1940) and Rhynchospora tenuis Link (Vanzela et al. 1996). In the last case, normal bivalents were only rarely observed.

The cytogenetic information obtained here shows quite variable karyotypes with chromosomes gradually decreasing in size, independently of the chromosome numbers, and the predominance of polyploidy. These results are useful in the differentiation of the subgenera, but when the comparisons are done within a subgenus, more detailed cytogenetical analyses (chromosome banding and cyto-molecular tools) are required. Future studies should combine these tools with molecular data to better understand the evolution of Eleocharis and related genera.

\section{Acknowledgements}

This study was supported by the Brazilian agencies Fundação Araucária, CNPq and ProPPG-UEL.

\section{References}

Alves MV, Araújo AC, Prata AP, Vitta F, Hefler S, Trevisan R, Gil ASB, Martins S, Thomas W (2009) Diversity of Cyperaceae in Brazil. Rodriguésia 60, 1-12.

Bozza CG, Pawlowski WP (2008) The cytogenetics of homologus chromosome pairing in meiosis in plants. Cytogenetic and Genome Research 120, 313-319. doi:10.1159/000121080

Bureš P, Rotreklová O, Stoneberg HSD, Pikner R (2004) Cytogeographical survey of Eleocharis subser. Eleocharis in Europe 1. Eleocharis palustris. Folia Geobotanica 39, 235-257. doi:10.1007/BF02804780

Da Silva CRM, González-Elizondo MS, Vanzela ALL (2005) Reduction of chromosome number in Eleocharis subarticulata (Cyperaceae) by multiple translocation. Botanical Journal of the Linnean Society 149, 457-464. doi:10.1111/j.1095-8339.2005.00449.x

Da Silva CRM, González-Elizondo MS, Rego LNAA, Torezan JMD, Vanzela ALL (2008a) Cytogenetical and cytotaxonomical analysis of some Brazilian species of Eleocharis. Australian Journal of Botany 56, 82-90. doi:10.1071/BT07017

Da Silva CRM, González-Elizondo MS, Vanzela ALL (2008b) Chromosome Reduction in Eleocharis maculosa (Cyperaceae). Cytogenetic and Genome Research 122, 175-180. doi:10.1159/000163096

Davies EW (1956) Cytology, evolution and origin of the aneuploid series in the genus Carex. Hereditas 42, 349-365.

Evans GM (1988) Genetic control of chromosome pairing in polyploids. In 'Kew Chromosome Conference III. Proceedings of the Third Chromosome Conference held in the Jodrell Laboratory, Royal Botanic Gardens, Kew, England, 1-4 September'. (Ed. PEBrandham) pp. 253-260.

Faulkner JS (1972) Chromosome studies on Carex section Acutae in northwest Europe. Botanical Journal of the Linnean Society 65, 271-301.

Goetghebeur P (1998) 'Cyperaceae. The families and genera of vascular plants: IV. Flowering plants - monocotyledons.' (Springer-Verlag: Berlin)

González-Elizondo MS, Peterson PM (1997) A classification of and key to the supraspecific taxa in Eleocharis (Cyperaceae). Taxon 46, 433-449. doi: $10.2307 / 1224386$

González-Elizondo MS, Tena-Flores JA (2000) Eleocharis (Cyperaceae) in the New World. In 'Monocots: Systematics and Evolution'. (Eds KL Wilson, DA Morrison) pp. 637-643. (CSIRO Publishing: Melbourne)

Grant V (1971) 'Plant Speciation'. (Columbia University Press: New York). Griffiths S, Sharp R, Foote TN, Bertin I, Wanous M, Reader S, Colas I, Moore $\mathrm{G}$ (2006) Molecular characterization of $\mathrm{Ph} 1$ as a major chromosome pairing locus in polyploid wheat. Nature 439, 749-752. doi:10.1038/nature04434

Håkansson A (1958) Holocentric chromosomes in Eleocharis. Hereditas 44, 531-540.

Harms LJ (1968) Cytotaxonomic studies in Eleocharis subser. Palustres: Central United taxa. American Journal of Botany 55, 966-974. doi: $10.2307 / 2440562$

Hipp AL, Rothrock PE, Roalson EH (2009) The evolution of chromosome arrangements in Carex (Cyperaceae). Botanical Review 75, 96-109. doi:10.1007/s12229-008-9022-8

Hoshino T (1987) Karyomorphological studies on 6 taxa of Eleocharis in Japan. Bulletin of the Okayama University of Science 22, 305-312.

Hoshino T, Okamura K (1994) Cytological studies on meiotic configurations of intraspecific aneuploids of Carex blepharicarpa (Cyperaceae) in Japan. Journal of Plant Research 107, 1-8. doi:10.1007/BF02344523

Hoshino T, Waterway MJ (1994) Cytogeography and meiotic chromosome configurations of six intraspecific aneuploids of Carex conica Boott (Cyperaceae) in Japan. Journal of Plant Research 107, 131-138. doi:10.1007/BF02346008 
Hoshino T, Rajbhandari KR, Ohba H (2000) Cytological studies of eleven species of Cyperaceae collected from Central Nepal. Cytologia 65, 219-224.

Kukkonen I (1990) On the genus Eleocharis (Cyperaceae) in Flora Iranica area, with revised infrageneric classification and nomenclature. Annales Botanici Fennici 27, 109-117.

Löve A, Löve D (1981) In IOPB chromosome number reports LXXIII. Taxon 30, $845-851$.

Luceño M (1993) Cytotaxonomic studies in the sections Spirostachyae (Drejer) Bailey and Ceratocystis Dumort. of the genus Carex L. (Cyperaceae), with special reference to Iberian and North Aftrican taxa. Botanical Journal of the Linnean Society 112, 335-350.

Luceño M, Castroviejo S (1991) Agmatoploidy in Carex laevigata (Cyperaceae). Fusion and fission of chromosomes as the mechanism of cytogenetic evolution in Iberian populations. Plant Systematics and Evolution 177, 149-159. doi:10.1007/BF00937952

Luceño M, Vanzela ALL, Guerra M (1998) Cytotaxonomic studies in Brazilian Rhynchospora (Cyperaceae), a genus exhibiting holocentric chromosomes. Canadian Journal of Botany 76, 440-449. doi:10.1139/cjb-76-3-440

Nijalingappa BHM (1972) In IOPB chromosome number reports. XXXVIII. Taxon 21, 679-684.

Nijalingappa BHM (1973) Cytological studies in Eleocharis. Caryologia 26, $512-520$.

Nijalingappa BHM (1977) Autotetraploidy in Fimbristylis falcata (Vahl) Kunth (Cyperaceae). Proceedings of the Indian Academy Science B 85, $21-24$.

Ohkawa T, Yokota M, Hoshino T (2000) Aneuploidal population differentiation in Carex sociata Boott (Cyperaceae) of the Ryukyu Islands, Japan. Botanical Journal of the Linnean Society 132, 337-358.

Otto SP (2007) The evolutionary Consequences of Polyploidy. Cell 131, 452-462. doi:10.1016/j.cell.2007.10.022

Pedrosa A, Gitai J, Silva AEB, Felix LP, Guerra M (1999) Citogenética de Angiospermas Coletadas em Pernambuco. Acta Botanica Brasilica 13, 49-60.

Rath SP, Patnaik SN (1978) Cytological studies in Cyperaceae. In 'Proceedings of the Indian Science Congress Association (III, C). Session 65, pp. 107-108, Ahmedabad, India.

Roalson EH (2008) A synopsis of chromosome number variation in the Cyperaceae. Botanical Review 74, 209-393. doi:10.1007/s12229-008-9011-y

Roalson EH, Friar EA (2000) Infrageneric classification of Eleocharis (Cyperaceae) revisited: evidence from the internal transcribed spacer (ITS) region of nuclear ribosomal DNA. Systematic Botany 25, 323-336. doi: $10.2307 / 2666645$

Roalson EH, Hinchliff C (2007) Phylogenetic relationships in Eleocharis R. Br. (Cyperaceae): comparisons with classification, morphology, biogeography and physiology. In ' $58^{\circ}$ Congresso Nacional de Botânica'. (Eds Sociedade Botânica do Brasil) pp. 304-307. (Botânica no Brasil: Pesquisa Ensino e Políticas Públicas)

Sanyal B, Sharma AK (1972) Cytological studies in Indian Cyperaceae. I. Tribe Scirpeae. Cytologia 37, 13-32.
Schuyler AE (1977) Chromosome observations on some eastern North American Eleocharis (Cyperaceae). Brittonia 29, 129-133. doi: $10.2307 / 2805751$

Simpson DA (1988) Some problems in Eleocharis. Notes on Brazilian Cyperaceae III. Kew Bulletin 43, 127-134. doi:10.2307/4118045

Strandhede SO (1964) Chromosome studies in Eleocharis subser. Palustres. I. Meiosis in some forms with 15 chromosomes. Hereditas 53, 47-62. doi:10.1111/j.1601-5223.1965.tb01979.x

Strandhede SO (1965) Chromosome studies in Eleocharis, subser. Palustres. Opera Botanica 9, 1-86.

Svenson HK (1929) Contributions from the Gray Herbarium of Harvard University. LXXXVI. Monographic studies in the genus Eleocharis. Rhodora 31, 121-245.

Svenson HK (1939) Monographic studies in the genus Eleocharis V. Rhodora 41, 1-110.

Tanaka N (1940) Chromosome studies in Cyperaceae, VIII: Meiosis in diploid and tetraploid forms of Carex siderosticta Hance. Cytologia 10, 282-310.

Trevisan R, Boldrini II (2008) O gênero Eleocharis R. Br. (Cyperaceae) no Rio Grande do Sul, Brasil. Revista Brasileira de Bociências 6, 7-67.

Vanzela ALL, Guerra M, Luceño M (1996) Rhynchospora tenuis Link (Cyperaceae), a species with the lowest number of holocentric chromosomes $(\mathrm{n}=2)$. Cytobios 88, 219-228.

Vanzela ALL, Luceño M, Guerra M (2000) Karyotype evolution and cytotaxonomy in Brazilian species of Rhynchospora Vahl (Cyperaceae). Botanical Journal of the Linnean Society 134, 557-566. doi:10.1111/j.1095-8339.2000.tb00551.x

Vanzela ALL, Cuadrado A, Guerra M (2003) Localization of 45S rDNA and telomeric sites on holocentric chromosomes of Rhynchospora tenuis Link (Cyperaceae). Genetics and Molecular Biology 26, 199-201. doi:10.1590/S1415-47572003000200014

Wahl HA (1940) Chromosome numbers and meiosis in the genus Carex. American Journal of Botany 27, 458-470. doi:10.2307/2437081

Yano O, Hoshino T (2005) Molecular phylogeny and chromosomal evolution of Japanese Schoenoplectus (Cyperaceae), based on ITS and ETS $1 \mathrm{f}$ sequences. Acta Phytotaxono Geobot 56, 183-195.

Yano O, Hoshino T (2006a) Phylogenetic relationships and chromosome evolution of Japanese Fimbristylis (Cyperaceae) using nrDNA ITS and ETS 1f sequence data. Acta Phytotaxonomica et Geobotanica 57, 205-217.

Yano O, Hoshino T (2006b) Cytological Studies of Aneuploidy in Eleocharis kamtschatica (Cyperaceae). Cytologia 71, 141-147. doi:10.1508/cytologia.71.141

Yano O, Hoshino T (2007) Karyomorphological Studies of Four Species of Japanese Scleria (Cyperaceae). Cytologia 72, 275-278. doi:10.1508/cytologia.72.275

Yano O, Katsuyama T, Tsubota H, Hoshino T (2004) Molecular phylogeny of Japanese Eleocharis (Cyperaceae) based on ITS sequence data, and chromosomal evolution. Journal of Plant Research 117, 409-419. doi:10.1007/s10265-004-0173-3

Manuscript received 21 October 2009, accepted 17 December 2009 


\section{Capítulo 2}

Cytogenetical and cytotaxonomical analysis of some Brazilian species of Eleocharis (Cyperaceae) 


\title{
Cytogenetical and cytotaxonomical analysis of some Brazilian species of Eleocharis (Cyperaceae)
}

\author{
Carlos Roberto Maximiano da Silva ${ }^{\mathrm{A}}$, Maria Socorro González-Elizondo ${ }^{\mathrm{B}}$, \\ Letícia do Nascimento Andrade de Almeida RegoC, José Marcelo Domingues Torezan ${ }^{\mathrm{C}}$ \\ and André Luís Laforga Vanzela ${ }^{\mathrm{C}, \mathrm{D}}$ \\ Anstituto de Biociências, Letras e Ciências Exatas, UNESP, São José do Rio Preto 15054-000, SP, Brazil. \\ ${ }^{B}$ Instituto Politécnico Nacional, CIIDIR and COFAA, Durango, Dgo. 34000, Mexico. \\ CLaboratório de Biodiversidade e Restauração de Ecossistemas, CCB, Universidade Estadual de Londrina, \\ Londrina 86051-990, PR, Brazil. \\ DCorresponding author. Email: andrevanzela@uel.br
}

\begin{abstract}
Karyotype analysis of 21 samples of 11 species of Eleocharis (Cyperaceae) from 10 localities in Brazil, showed the presence of chromosomes without primary constrictions and parallel movement of chromatids at metaphase-anaphase transition. Only the terminal nucleolar constrictions (satellites) were visualised. The chromosome numbers varied from $2 n=6$ in E. subarticulata to $2 n=54$ in E. acutangula, but the chromosome basic number $x=5$ was confirmed. Generally, $\mathrm{C}-\mathrm{CMA}_{3}{ }^{+}$bands appear mostly in the extremities of the chromosomes, associated to NOR, and interstitial C-CMA 3 bands were found only in E. geniculata and E. acutangula. C-DAPI ${ }^{+}$bands were not found. Fluorescence in situ hybridisation (FISH) with the 45S rDNA probe was performed in five species. The results showed from four to eight hybridisation signals, always terminal. The analysed species include representatives of the following three subgenera of Eleocharis that occur in Brazil: Limnochloa, Scirpidium and Eleocharis. Species from the subgenus Limnochloa have small and numerous chromosomes. The remaining species, belonging to subgenera Eleocharis and Scirpidium, possess fewer and larger chromosomes. In subgenus Eleocharis, karyotypes of the section Eleocharis were differentiated by symploidy, agmatoploidy and polyploidy, whereas species of the section Eleogenus were all polyploids. Polyploidy seems to be the most frequent event in the karyotype differentiation in Eleocharis, but changes in the chromosome size and repetitive DNA sites were also observed.
\end{abstract}

\section{Introduction}

Eleocharis comprises $\sim 200$ species, which are frequently found in flooded areas (Svenson 1929; González-Elizondo and Peterson 1997). Eleocharis is distinguished from the other genera of Cyperaceae by possessing stems with leaves reduced to a basal, tubular sheath, persistent style base, and inflorescence reduced to a simple terminal spikelet (González-Elizondo and Peterson 1997). In spite of the easy recognition of Eleocharis as a genus in the field and its prominent delimitation within Cyperaceae (Kukkonen 1990), the species are difficult to identify and classify because of the limited number of morphological features. The supraspecific classification of Eleocharis has been revised and modified in recent years (Faria 1998) and the more global classifications are those proposed by Kukkonen (1990) and González-Elizondo and Peterson (1997), on the basis of the widely accepted classification of Svenson (1929, 1932, 1934, 1937, 1939).

Most of the cytogenetical knowledge in Cyperaceae comes from studies in Carex and Rhynchospora (Davies 1956; Faulkner 1972; Luceño et al. 1998; Vanzela et al. 2000). These and other authors accept that the species of Cyperaceae possess uncommon cytogenetical features such as (i) holocentric chromosomes, (ii) post-reductional meiosis, (iii) absence of tetrads, owing to degeneration of three of the four nuclei during pollen mitosis and (iv) karyotype evolution on the basis of agmatoploidy (fission), symploidy (fusion) and polyploidy. The occurrence of holocentric chromosomes in Eleocharis was proposed by Håkansson (1954), after treating samples of E. palustris with $\mathrm{X}$-ray and the observation of the normal kinetic behaviour of the chromosome fragments produced in subsequent cellular cycles. Greilhuber (1995) suggested that the occurrence of holocentric chromosomes is a synapomorphy of the Cyperaceae. Recently, Guerra et al. (2005) studied the behaviour of holocentric chromosomes of Rhynchospora tenuis (Cyperaceae) by immunodetection with anti-tubulin, and found that during the metaphase, the microtubules are attached along the whole chromosome extension, typical of holokinetic chromosomes.

Cytogenetical studies in Eleocharis date from the early 1920 s, when Piech described the chromosome number of E. palustris (Nijalingappa 1973). There is considerable variation in the chromosome numbers in the genus, from $2 n=6$ (da Silva et al. 2005) to $2 n=\sim 196$ (Hoshino 1987); however, most of the species present the numbers $2 n=10,20,30$ and 40, associated with the possible basic number $x=5$. Intraspecific differences in the chromosome numbers were reported in E. geniculata with $2 n=10$ and 20, in E. atropurpurea 
with $2 n=20$ and 21 (Nijalingappa 1973) and E. palustris with $2 n=15$ and 16 (Strandhede 1964), which originated by agmatoploidy/symploidy. More recently, Bureš et al. (2004) showed that E. palustris subsp. palustris has $2 n=16$, rarely 15 , whereas $E$. palustris subsp. vulgaris frequently has $2 n=38$ and can range from 36 to 42. Yano et al. (2004) showed the occurrence of mixoploidy in the Japanese E. acicularis $\mathrm{f}$. longiseta $(2 n=20$ and 21). These authors, on the basis of cytogenetical and molecular studies, have proposed a cytological division of the genus into the following two groups: (i) species with karyotypes composed of small and numerous chromosomes (E. section Limnochloa) and (ii) species with big and less numerous chromosomes (other sections).

Some studies about repetitive DNA segments in members of the Cyperaceae report the existence of numerous GC-rich heterochromatic blocks in Carex (Greilhuber 1995) and the occurrence of different heterochromatin types $\left(\mathrm{C}-\mathrm{Giemsa}^{+}, \mathrm{CMA}_{3}{ }^{+} / \mathrm{DAPI}^{-}, \mathrm{CMA}_{3}{ }^{+} / \mathrm{DAPI}^{+}\right.$and $\mathrm{CMA}_{3}{ }^{-}-$ $\mathrm{DAPI}^{+}$) in Rhynchospora (Vanzela and Guerra 2000). FISH with $45 \mathrm{~S}$ rDNA probes in members of Cyperaceae was performed on eight species of Rhynchospora by Vanzela et al. (1998). These authors found large variation in the number of sites, but stability in localisation, since all the sites were terminal. FISH with rDNA probes was also performed in Eleocharis and Carex by Furuta and Hoshino (1999), who found that in E. mamillata var. cyclocarpa $(2 n=16)$ the $18 \mathrm{~S}$ rDNA probe hybridised in 12 of the 16 chromosomes of the complement, always in the terminal positions. Terminal $45 \mathrm{~S}$ rDNA sites were also found in E. subarticulata with $2 n=6$ (da Silva et al. 2005). FISH with the $5 \mathrm{~S}$ rDNA probe hybridised in the interstitial positions of two chromosomes. In Carex pachgyna and C. ciliato-marginata, both with $2 n=12$, the $5 \mathrm{~S}$ rDNA probe localised segments in the terminal and interstitial regions and 18S rDNA probe always hybridised in the terminal regions. These examples indicate that these repetitive DNA families are dynamics and present a great potential to study the karyotype differentiation and evolution in this genus.

In the present study, the karyotypes of 21 samples of 11 species of Eleocharis (Cyperaceae) from 10 localities in Brazil were analysed. The aim of the study was to contribute to knowledge on the relationship between size, chromosome number and taxonomic grouping, such as those proposed by Yano et al. (2004). We also focused on the importance of DNA segment repeats in karyotype differentiation in Eleocharis.

\section{Materials and methods}

Twenty-one samples representing 11 species of Eleocharis were collected in 10 different localities of south-eastern and southern Brazil. Vouchers were deposited in herbarium FUEL. In a few localities, more than one species was collected (Table 1).

Table 1. Chromosome count and size in Brazilian species of Eleocharis

Species are grouped according to González-Elizondo and Peterson (1997)

\begin{tabular}{|c|c|c|c|}
\hline Species & $2 n$ & Size $(\mu \mathrm{m})$ & Localities (coordinates) and voucher number \\
\hline \multicolumn{4}{|l|}{ Subgenus Eleocharis S.González \& } \\
\hline \multicolumn{4}{|l|}{ P.M.Peterson } \\
\hline \multicolumn{4}{|l|}{ Section Eleocharis S. González \& } \\
\hline \multicolumn{4}{|l|}{ P.M.Peterson } \\
\hline E. subarticulata (Nees) Boeckl. & 6 & $3.0-1.5$ & Ponta Grossa, Paraná, $\left(25^{\circ} 05^{\prime} 06^{\prime \prime} \mathrm{S}, 50^{\circ} 09^{\prime} 57^{\prime \prime} \mathrm{W}\right), 35.411$. \\
\hline E. minima Kunth $^{\mathrm{A}}$ & 12 & $2.7-0.9$ & Sapopema, Paraná, $\left(23^{\circ} 53^{\prime} 06^{\prime \prime} \mathrm{S}, 50^{\circ} 35^{\prime} 24^{\prime \prime} \mathrm{W}\right), 35.403$. \\
\hline \multirow[t]{2}{*}{ E. montana (Kunth) Roem. \& Schult ${ }^{\mathrm{A}}$} & 20 & $2.3-1.3$ & Bela Vista do Paraíso, Paraná $\left(23^{\circ} 01^{\prime} 36^{\prime \prime} \mathrm{S}, 51^{\circ} 12^{\prime} 36^{\prime \prime} \mathrm{W}\right), 36.079$; Bela \\
\hline & 40 & $2.2-1.1$ & $\begin{array}{l}\text { Vista do Paraíso, Paraná 36.081; Rolândia, Paraná }\left(23^{\circ} 19^{\prime} 48^{\prime \prime} \mathrm{S} \text {, }\right. \\
\left.51^{\circ} 22^{\prime} 21^{\prime \prime} \mathrm{W}\right), 35.422 \text {; Assaí, Paraná }\left(23^{\circ} 22^{\prime} 12^{\prime \prime} \mathrm{S}, 50^{\circ} 49^{\prime} 48^{\prime \prime} \mathrm{W}\right) \text {, } \\
\text { 36.073; Sapopema, Paraná, 36.064. }\end{array}$ \\
\hline E. elegans (HBK) R \& $\mathrm{S}^{\mathrm{A}}$ & 40 & $2.2-1.0$ & Assaí, Paraná, 36.074 \\
\hline \multicolumn{4}{|l|}{ Section Eleogenus (Nees) Benth. \& Hook. } \\
\hline E. flavescens (Poir.) Urban ${ }^{\mathrm{A}}$ & 10 & $2.0-1.3$ & Rolândia, Paraná, 35.424. \\
\hline E. maculosa (Vahl) Roem \& Schult. ${ }^{\mathrm{A}}$ & 10 & $2.4-1.6$ & $\begin{array}{l}\text { Florianópolis, Santa Catarina }\left(27^{\circ} 34^{\prime} 12^{\prime \prime} \mathrm{S}, 48^{\circ} 31^{\prime} 48^{\prime \prime} \mathrm{W}\right), 35.406 \text {; Tibagi, } \\
\quad \text { Paraná }\left(24^{\circ} 32^{\prime} 06^{\prime \prime} \mathrm{S}, 50^{\circ} 24^{\prime} 18^{\prime \prime} \mathrm{W}\right), 35.434 .\end{array}$ \\
\hline E. sellowiana Kunth. ${ }^{\mathrm{A}}$ & 20 & $2.6-1.4$ & $\begin{array}{l}\text { Ibitinga, São Paulo }\left(21^{\circ} 45^{\prime} 11^{\prime \prime} \mathrm{S}, 49^{\circ} 01^{\prime} 33^{\prime \prime} \mathrm{W}\right), 35.429 \text {; Rolândia, Paraná, } \\
\text { 35.426; Bela Vista do Paraíso, Paraná, } 36.080 \text {. }\end{array}$ \\
\hline E. geniculata (L.) Roem \& Schult. & 20 & $3.2-4.1$ & Ponta Grossa, Paraná $\left(24^{\circ} 59^{\prime} 24^{\prime \prime} \mathrm{S}, 49^{\circ} 59^{\prime} 24^{\prime \prime} \mathrm{W}\right), 36.084$ \\
\hline \multicolumn{4}{|l|}{ Subgenus Limnochloa (P.Beauv. ex Lestib.) Torr. } \\
\hline \multicolumn{4}{|l|}{ Section Limnochloa (P.Beauv. ex T.Lestib.) } \\
\hline \multicolumn{4}{|l|}{ Benth. \& Hook. f. } \\
\hline E. brasiliensis Boeck $^{\mathrm{A}}$ & $\sim 54^{\mathrm{B}}$ & & $\begin{array}{l}\text { Biological collection of Unicamp, Campinas, São Paulo }\left(22^{\circ} 48^{\prime} 48^{\prime \prime} \mathrm{S} \text {, }\right. \\
\left.47^{\circ} 04^{\prime} 12^{\prime \prime} \mathrm{W}\right), 35.405 \text {. }\end{array}$ \\
\hline E. acutangula (Roxb.) Schult. & 54 & $1.2-0.7$ & $\begin{array}{l}\text { Rio Claro, São Paulo }\left(22^{\circ} 24^{\prime} 54^{\prime \prime} \mathrm{S}, 22^{\circ} 24^{\prime} 55^{\prime \prime} \mathrm{W}\right), 35.455 \text {; Rolândia, } \\
\text { Paraná, 35.420; Assaí, Paraná, 36.075; Sapopema, Paraná, 36.068. }\end{array}$ \\
\hline \multicolumn{4}{|l|}{ Subgenus Scirpidium (Nees) Kukk. } \\
\hline \multicolumn{4}{|l|}{ Section Scirpidium (Nees) Benth. \& Hook. f. } \\
\hline
\end{tabular}

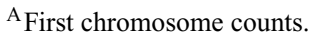

${ }^{\mathrm{B}}$ Approximate chromosome number. 
Samples were cultivated in the nursery of the Laboratório de Biodiversidade e Restauração de Ecossistemas at Universidade Estadual de Londrina, Londrina, Brazil.

Karyotype analyses were performed with root tips pre-treated in $2 \mathrm{mM} 8$-hydroxyquinoline for $24 \mathrm{~h}$, fixed in ethanol : acetic acid $(3: 1, \mathrm{v}: \mathrm{v})$ for $24 \mathrm{~h}$, and stored at $-20^{\circ} \mathrm{C}$ or immediately used. For the conventional staining, the root tips were washed in distilled water, softened in $4 \%$ cellulase plus $40 \%$ pectinase at $37^{\circ} \mathrm{C}$ for $3 \mathrm{~h}$, hydrolysed in $1 \mathrm{M} \mathrm{HCl}$ for $10 \mathrm{~min}$ at $60^{\circ} \mathrm{C}$, washed again in distilled water, and squashed in a drop of $45 \%$ acetic acid. Slides were stained in $2 \%$ giemsa and mounted with Entellan (Merck). The chromosome counts were made in at least 20 cells for each sample. For calculating the chromosome sizes, at least 10 cells with good chromosome morphology and similar condensation and spreading ability were measured, and the mean length was calculated for each pair. To test the parallel migration of the holocentric chromosomes in anaphases, slides were prepared with meristems obtained without a previous treatment with anti-mitotic agent and directly fixed in ethanol : acetic acid, as described above.

For chromosome banding, fixed samples were washed in distilled water, softened in $4 \%$ cellulase plus $40 \%$ pectinase at $37^{\circ} \mathrm{C}$ for $3 \mathrm{~h}$, washed again and squashed in a drop of $45 \%$ acetic acid, without acid hydrolysis. After freezing in liquid nitrogen for coverslip removal, preparations were aged for later $\mathrm{C}-\mathrm{CMA}_{3}$ banding or immediately used for FISH with the $45 \mathrm{~S}$ rDNA probe. For $\mathrm{C}_{-} \mathrm{CMA}_{3}$ banding, preparations were treated according to Schwarzacher et al. (1980), with modifications. Slides were incubated in $45 \%$ acetic acid at $60^{\circ} \mathrm{C}$ for $10 \mathrm{~min}, 5 \% \mathrm{Ba}(\mathrm{OH})_{2}$ at $25^{\circ} \mathrm{C}$ for $10 \mathrm{~min}$ and $2 \times \mathrm{SSC}$ $\mathrm{pH} 7.0$ at $60^{\circ} \mathrm{C}$ for $1 \mathrm{~h}$ and $30 \mathrm{~min}$, and to finish, the samples were air-dried. After 3 days, samples were stained with a drop of $0.5 \mu \mathrm{g} \mu \mathrm{L}^{-1} \mathrm{CMA}_{3}$ containing $2.5 \mathrm{mM} \mathrm{MgCl}_{2}$ for $1 \mathrm{~h}$ $30 \mathrm{~min}$, washed in distilled water and subsequently stained with $2 \mu \mathrm{g} \mathrm{mL}^{-1}$ DAPI for $30 \mathrm{~min}$. Slides were mounted in a solution of glycerol: Mcllvaine buffer, $\mathrm{pH} 7.0,(1: 1, \mathrm{v}: \mathrm{v})$ containing $2.5 \mathrm{mM} \mathrm{MgCl}_{2}$.

FISH was carried out with the $\mathrm{p} T a 71$ probe containing $45 \mathrm{~S}$ rDNA isolated from wheat (Gerlach and Bedbrook 1979). The probe was labelled with biotin-14-dATP by nick translation. Material was incubated in RNase $\left(100 \mu \mathrm{g} \mathrm{mL}^{-1}\right)$, post-fixed in $4 \%(\mathrm{w} / \mathrm{v})$ paraformaldehyde, dehydrated in a $70 \%$ and $100 \%$ graded ethanol series for $5 \mathrm{~min}$ each and air-dried. A hybridisation mix $(30 \mu \mathrm{L}$ per slide), containing $100 \mathrm{ng}$ of labelled probe $(4 \mu \mathrm{L}), 100 \%$ formamide $(15 \mu \mathrm{L}), 50 \%$ polyethylene glycol $(6 \mu \mathrm{L}), 10 \%$ SDS $(1 \mu \mathrm{L}), 100 \mathrm{ng}$ of calf thymus DNA $(1 \mu \mathrm{L})$ and $20 \times \operatorname{SSC}(3 \mu \mathrm{L})$, was denatured at $70^{\circ} \mathrm{C}$ for $10 \mathrm{~min}$ and immediately chilled on ice. Chromosome denaturation/hybridisation was performed at $90^{\circ} \mathrm{C}$ for $10 \mathrm{~min}$, $50^{\circ} \mathrm{C}$ for $10 \mathrm{~min}$ and $38^{\circ} \mathrm{C}$ for $5 \mathrm{~min}$ with a thermal cycler, and kept at $37^{\circ} \mathrm{C}$ overnight in a moist chamber. Posthybridisation washes were performed at $80 \%$ stringency in $2 \times \mathrm{SSC}, 0.1 \times \mathrm{SSC} / 20 \%$ formamide, $0.1 \times \mathrm{SSC}, 2 \times \mathrm{SSC}$ and $4 \times \mathrm{SSC} / 0.2 \%$ Tween 20 , at $42^{\circ} \mathrm{C}$ for $5 \mathrm{~min}$ each. The biotinlabelled probe was detected with avidin FITC-conjugate, and slides were mounted in an antifade solution $(2.3 \%$ of $1,4-$ diaza- bicyclo(2.2.2)-octane, $20 \mathrm{mM}$ TRIS-HCl, $\mathrm{pH}$ 8.0, and $90 \%$ glycerol, in distilled water) containing propidium iodide $\left(1 \mu \mathrm{g} \mathrm{mL}^{-1}\right)$. Images were taken with a Leica DM $4500 \mathrm{~B}$ microscope equipped with a DFC $300 \mathrm{FX}$ camera and Leica IM50 4.0 software (all from Leica Microsystems).

\section{Results and discussion}

\section{Karyotype features and cytotaxonomy}

The reduction in morphological structures of Eleocharis also reaches the chromosome level. Cyperaceae possess holocentric chromosomes, so that it is not possible to compare populations and species by the use of chromosome shape. Cytogenetical features, such as nucleolar constrictions, chromosome size and interphase nuclei types, can be useful to study many plant groups; however, this information is scarce in the literature on Cyperaceae. Hoshino (1987) reported that interphasic nuclei in Eleocharis possess diffuse chromatin with spherical bodies stained darkly and with differences in size. The nuclei described by Hoshino (1987), as well as those found in the present study, and those described by Vanzela et al. (2000) in Rhynchospora, are similar to the chromocentric interphase nuclei described by Kondo et al. (1994) in Drosera (Droseraceae), which also has holocentric chromosomes. Thus, the occurrence of chromocentric nuclei in all the studied species of Eleocharis, with minor differences in the chromocenter size (see Fig. $1 c, d, g$ ), suggests that this feature is not a useful cytotaxonomic tool to separate species and subgenera of Eleocharis; however, it indicates that besides the holokinetic chromosomes (Greilhuber 1995), the nucleus type may also be a synapomorphy of the Cyperaceae.

None of the species studied presented primary constrictions in the chromosomes and, additionally, the chromosomes migrate parallel to the equatorial plate axis at anaphase, as can be observed e.g. in E. sellowiana (Fig. 1a). The absence of Rabl organisation during separation of sister chromatids in Cyperaceae, was previously noted in $R$. tenuis (Vanzela et al. 1996), and confirmed recently by Guerra et al. (2005), after the detection of mitotic apparatus with anti- $\alpha$-tubulin antibody. Several studies have shown the occurrence of holocentric chromosomes in Eleocharis (Strandhede 1965; Hoshino 1987; da Silva et al. 2005), reinforcing that the holokinetic condition of the chromosomes may be a synapomorphy of the family, as proposed by Greilhuber (1995).

Fig. 1. Conventional chromosome analysis in Eleocharis. (a) Anaphase in Eleocharis sellowiana, showing the parallel movement of the chromosomes at the equatorial plate; (b) metaphase with $2 n=6$ in E. subarticulata; $(c)$ metaphase with $2 n=10$ in E. maculosa; $(d)$ metaphase with $2 n=10$ in E. flavescens (note the chromocentric interphase nuclei in $c$ and $d$ ); $(e)$ metaphase with $2 n=10$ in E. radicans (arrows point to the terminal nucleolar constrictions (satellites)); $(f)$ prometaphase with $2 n=12$ in E. minima; two small chromosomes (arrows); $(g)$ metaphase with $2 n=20$ in $E$. geniculata; adjacent, a diffuse chromocentric nucleus; $(h)$ prometaphase with $2 n=20$ in $E$. sellowiana; arrows point to two satellites; metaphase in $E$. montana with $(i) 2 n=20$ and (j) $2 n=40 ;(k)$ metaphase with $2 n=40$ in E. elegans; $(l)$ metaphase with $2 n=\sim 54$ in E. brasiliensis; and $(m)$ metaphase with $2 n=54$ in $E$. acutangula; arrows point to two minor satellites. Scale bar $=10 \mu \mathrm{m}$. 


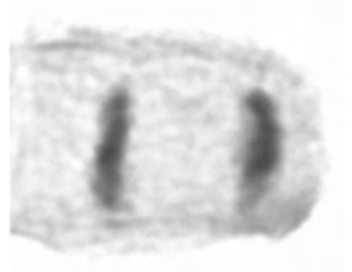

(a)

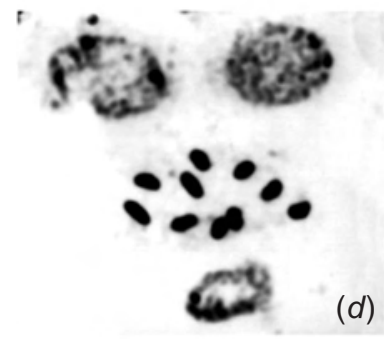

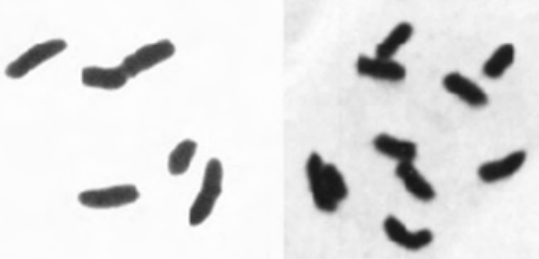

(b)

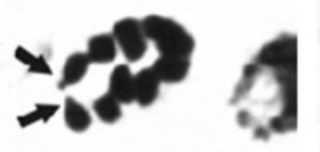

(e)

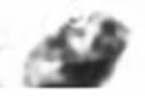

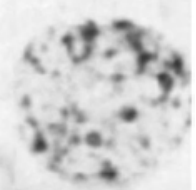

(c)

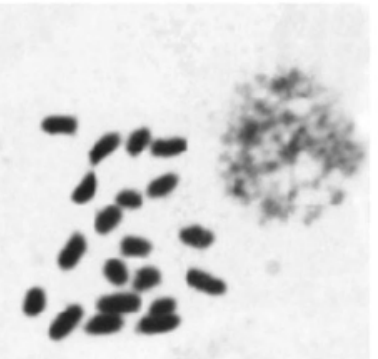

(g)

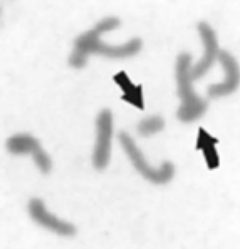

$3(f)$
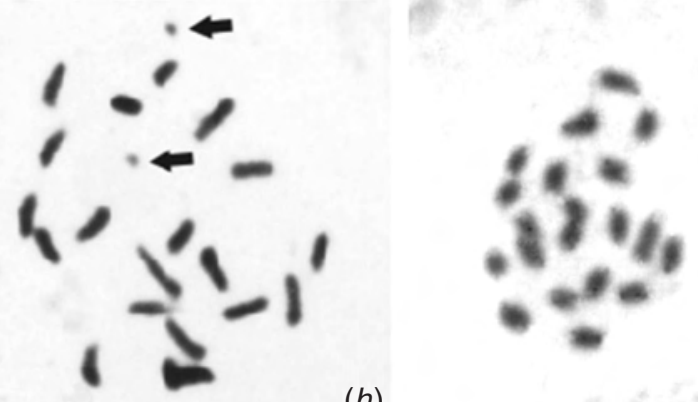

(h)
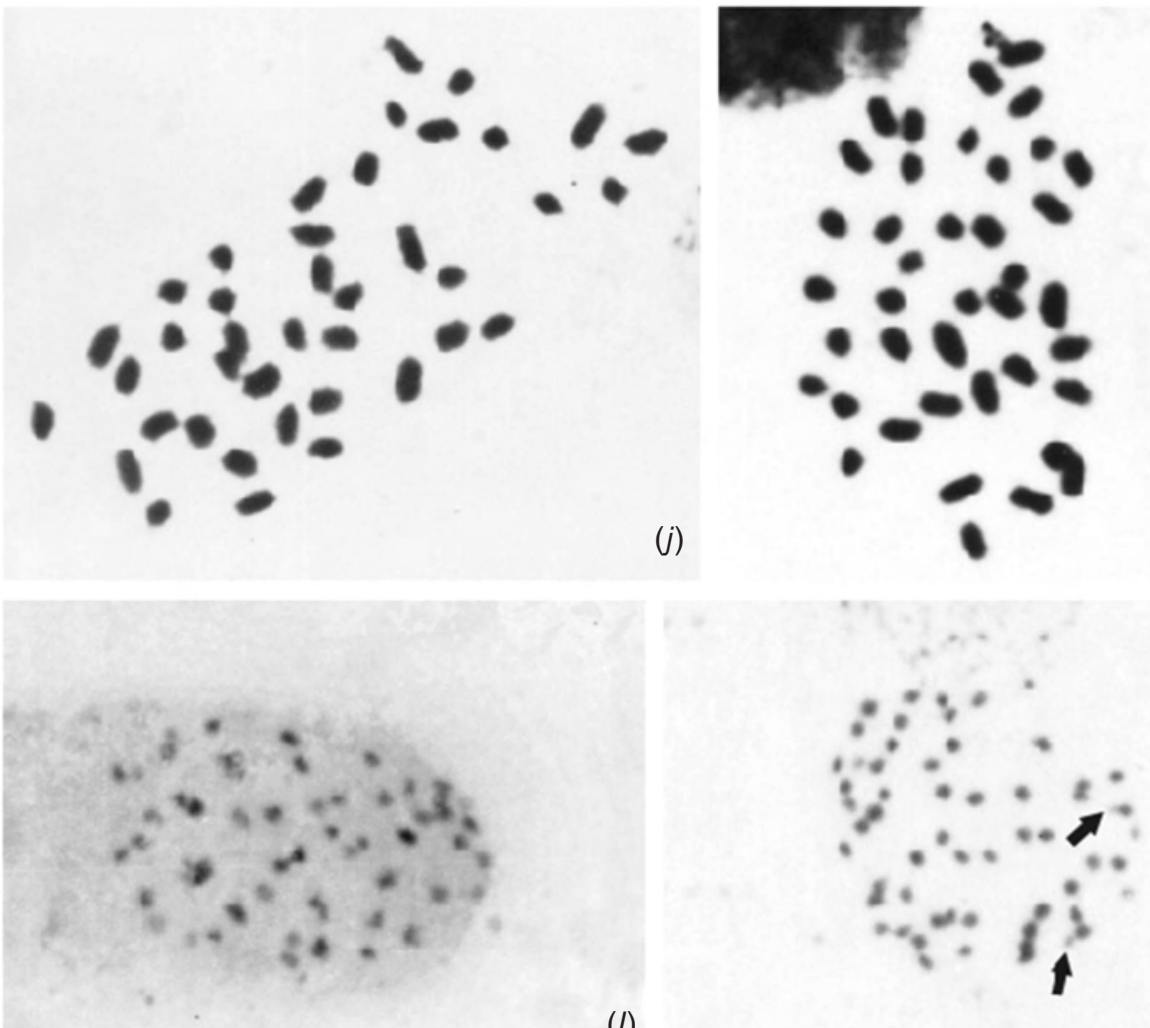
For eight of the species studied (Fig. 1f, $h-l$; Table 1), the chromosome number is documented here for the first time. Chromosome number for the other three (E. acutangula, E. geniculata and E. subarticulata) are confirmed here (Fig. $1 b, g, m$; Table 1). The number varied from $2 n=6$ in E. subarticulata (Fig. $1 b$ ) to $2 n=\sim 54$ in E. brasiliensis and $2 n=54$ in E. acutangula (Fig. $1 l, m$ ). E. maculosa (Fig. 1c), E. flavescens (Fig. 1d) and E. radicans (Fig. 1e) exhibited $2 n=10$, whereas E. geniculata and E. sellowiana showed a duplicated chromosome number, with $2 n=20$ (Fig. $1 g, h$ ). An intermediate chromosome number, $2 n=12$, was found in E. minima (Fig. 1 $f$ ); however, in this species, two of the chromosomes are very small (arrows). Cytotypes were found in E. montana with $2 n=20$ and 40 (Fig. $1 i, j$ ). In this case, the chromosomes of the cytotype with $2 n=20$ varied from 1.3 to $2.3 \mu \mathrm{m}$, and those of the cytotype with $2 n=40$ varied from 1.1 to $2.2 \mu \mathrm{m}$. The total length of the complement was twice the normal length in the populations with $2 n=40$. Significant morphological differences were not found between the two cytotypes of $E$. montana, suggesting that the polyploidisation to $2 n=40$ could be a recent event, since it does not yet affect the gross morphology. The chromosome number $2 n=40$ was also found in E. elegans (Fig. 1k). Another interesting case involves E. sellowiana and E. flavescens, two species in which the morphological characters, in some instances, are not enough to distinguish them. Some differences are the transversally elliptic stems in E. flavescens but circular in E. sellowiana (Faria 1998). Also, the upper portion of the distal sheath is not abruptly differentiated from the lower portion in E. flavescens, whereas in E. sellowiana it is abruptly differentiated (González-Elizondo et al. 2005). Populations of E. sellowiana, when slender or depauperate, may be morphologically very similar to and difficult to differentiate from E. flavescens. However, the karyotype of these species can be considered an additional micromorphological feature useful to taxonomy, since E. sellowiana possesses $2 n=20$ and E. flavescens $2 n=10$.

Intraspecific variations, as those found here, are common in Eleocharis and some other Cyperaceae. Numerical variations were described by Bureš et al. (2004) in an extensive study of 78 European populations of E. palustris subsp. palustris. These authors found three prevalent cytotypes, namely, the diploid with $2 n=16$ and, in fewer samples, the symploid $(2 n=15)$ and the mixoploid $(2 n=15$ and 16). Ohkawa et al. (2000) studied different populations of Carex sociata from Japan and found numbers varying from $2 n=40$ to 44 , with prevalence of $2 n=42$ and 44. Such variations have also been found in genera such as Fimbristylis: F. bisumbellata and $F$. dichotoma, both with populations with $2 n=10$ and 20 , and $F$. falcata with $n=11$ and 22 (Bir et al. 1992). In the genus Rhynchospora, $R$. ciliata was treated as a subspecies of $R$. nervosa; however, $R$. ciliata showed $2 n=10$ and $R$. nervosa $2 n=30$; thus, Luceño et al. (1998) proposed that they could be considered as two different species. Polyploid and diploid cytotypes have been found in E. geniculata, with $2 n=10$ and 20, and E. atropurpurea with $2 n=20$ and 21 (Nijalingappa 1973). The study that described the largest numerical variations among related species was published by Strandhede (1965). This author showed that in
E. subser. Eleocharis, E. mamillata has $2 n=16$, E. palustris subsp. palustris has $2 n=15$ and $16, E$. palustris subsp. vulgaris showed $2 n=36,38,39$ and 42 , and E. uniglumis $2 n=46$ and $2 n=74$ to 82 .

Most of the chromosome numbers found in Eleocharis are multiples of $x=5$, which is in line with the proposition of Löve et al. (1957) about Cyperaceae. This basic number is common in some close genera, such as Bulbostylis, Fimbristylis (Bir et al. 1992) and Abildgaardia subser. (André L. L. Vanzela 2006, unpubl. data), but also in other, more distant genera, such as Rhynchospora (Luceño et al. 1998). Secondary basic numbers have also been detected in Eleocharis; however, these are probably derived from structural changes. E. subarticulata with $2 n=6$ is a good example. In this case, there was a reduction owing to multiple translocations (da Silva et al. 2005). Reduction in the number by fusion of holocentric chromosomes was reported in $R$. tenuis, with $2 n=4$ (Vanzela et al. 1996) and Fimbristylis umbellaris with $2 n=6$ (Rath and Patnaik 1978). If we consider $x=5$ as the primary basic number of Eleocharis, it is possible that the two minor chromosomes found in E. minima with $2 n=12$ appeared by fission (agmatoploidy) and the numbers $2 n=\sim 54$ found in E. brasiliensis and $2 n=54$ found in E. acutangula (Fig. $1 l, m$ ) probably originated from agmatoploidy followed by or preceding polyploidy. It is also possible that the high chromosome number in these species has appeared by widespread chromosome fission and not only by polyploidy. A similar event was reported by Nordenskiöld (1951), who observed that in some polyploid species of Luzula (Juncaceae), the holocentric chromosomes seemed to be half the size of those of the diploid species. An increase in the chromosome number resulting from agmatoploidy has been described in several genera of Cyperaceae. As examples, there are numerical variations in genera close to Eleocharis, such as Schoenoplectus with $2 n=42,44$ and 78 (Jankun 1989; Löve and Löve 1981) and Scirpus with $2 n=20,31,32,34$, 37, 48, 50, 56, 60 and 62 (Heiser 1979; Harriman 1981; Löve and Löve 1981; Pignotti and Fiorini 1998; Subramanian 1988).

Chromosome sizes of the species studied are shown in Table 1. Hoshino (1987) proposed the existence of the following three karyotype variations in Eleocharis in relation to the chromosome size: (i) bimodal variation, with two groups of chromosomes of distinctly different sizes, (ii) gradual variation, where the chromosomal size decreases gradually and (iii) homogeneous variation, where all the chromosomes are similar, and very small. Yano et al. (2004) studied several Japanese species of Eleocharis and suggested that Eleocharis can be divided into two groups according to chromosome sizes. The first includes species with very small chromosomes $(<1.1 \mu \mathrm{m}$ in length), and the second includes species with chromosome sizes ranging from 1.4 to $4.3 \mu \mathrm{m}$. The chromosome measurements made in the present study corroborate the analyses by Hoshino (1987), and partially corroborate the results of Yano et al. (2004); the species of subgenus Limnochloa (E. acutangula and $E$. brasiliensis) have many and smaller chromosomes $(1.2-0.7 \mu \mathrm{m})$, whereas size is variable in the species of the subgenera Eleocharis and Scirpidium, ranging from 4.1 
to $1.2 \mu \mathrm{m}$ (and even $0.9 \mu \mathrm{m}$ in the small chromosomes of E. minima). Species of subgenera Eleocharis and Scirpidium exhibit a bimodal pattern of karyotype, where the numbers form a gradual, incremental sequence of numbers. Our findings are consistent with the classification system proposed by González-Elizondo and Peterson (1997) and with the
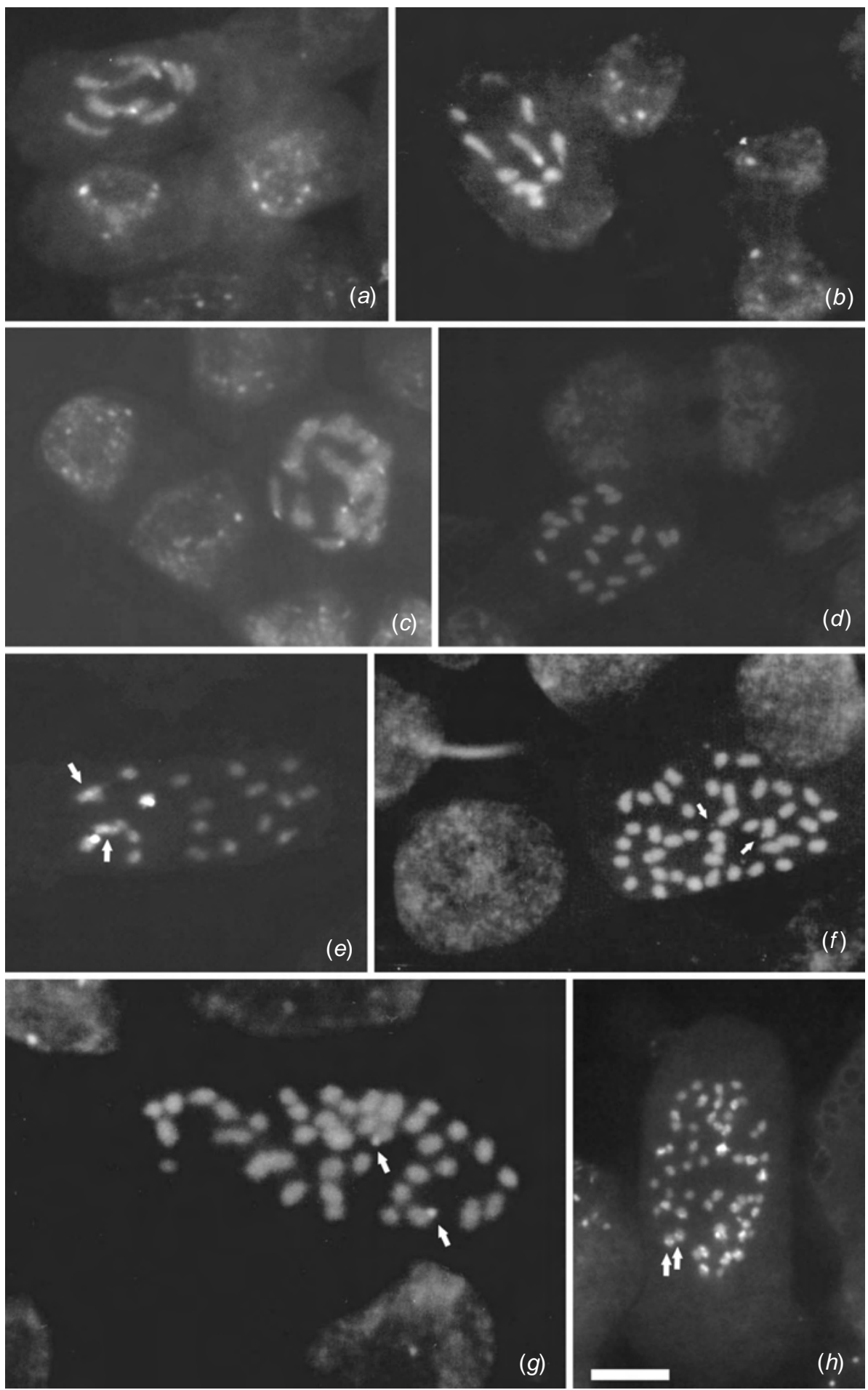

Fig. 2. C-CMA 3 /DAPI banding in Eleocharis. (a) Eleocharis flavescens $(2 n=10)$ with four terminal $\mathrm{CMA}_{3}$ blocks; $(b) E$. maculosa $(2 n=10)$ with four terminal $\mathrm{CMA}_{3}$ blocks; (c) E. sellowiana $(2 n=20)$ with about 10 terminal C-CMA 3 blocks; $(d)$ C- DAPI banding in E. sellowiana; note the absence of DAPI blocks; (e) E. geniculata $(2 n=20)$, showing two larger terminal C-CMA 3 blocks and two smaller and interstitial $($ arrows $) ;(f) E$. elegans $(2 n=40)$; arrows indicate the two tenuous and terminal $\mathrm{C}_{-} \mathrm{CMA}_{3}$ blocks; note the absence of signals in the nuclei; $(g) E$. montana $(2 n=40)$ with two terminals $\mathrm{C}_{-} \mathrm{CMA}_{3}$ blocks (arrows); and $(h)$ E. acutangula $(2 n=54)$ with $\sim 20$ terminal and few interstitial C-CMA 3 bands; the arrows point to two interstitial blocks. Scale bar $=5 \mu \mathrm{m}$. 
phylogenetical analysis based on ITS proposed by Roalson and Friar (2000).

\section{Repetitive DNA and chromosome organisation}

The $\mathrm{C}-\mathrm{CMA}_{3} / \mathrm{DAPI}$ banding showed that the studied species have no DAPI bands (Fig. $2 d$ ), suggesting that AT-rich sequences seem not to be important in the karyotype organisation. However, most of the species showed fine terminal $\mathrm{C}-\mathrm{CMA}_{3}$ bands (GC-rich blocks), with low fluorescence intensity, but varying in the number and size of the bands. E. flavescens and E. maculosa, both with $2 n=10$, exhibited four C-CMA $\mathrm{C}_{3}$ signals, two signals being slightly larger and two smaller (Fig. $2 a, b$ ). E. sellowiana with $2 n=20$ exhibited $\sim 10$ C-CMA 3 blocks, eight being more conspicuous and two fine (Fig. $2 c$ ). E. geniculata with $2 n=20$ showed four $\mathrm{C}-\mathrm{CMA}_{3}$ blocks, two being larger and terminal and two smaller and interstitial. Interestingly, these interstitial blocks were found in the largest pair (Fig. 2e). E. elegans and E. montana, both with $2 n=40$, showed tenuous $\mathrm{C}-\mathrm{CMA}_{3}{ }^{+}$ bands always in one chromosome pair (Fig. $2 f, g$ ). Interestingly, $E$. acutangula, the species with the smallest chromosomes, presented the largest number of $\mathrm{C}-\mathrm{CMA}_{3}{ }^{+}$bands, with $\sim 20$ interstitial and terminal bands (Fig. $2 h$ ). In spite of the very small number of treated species for the chromosome banding, these data indicate that heterochromatin rich in GC is very important
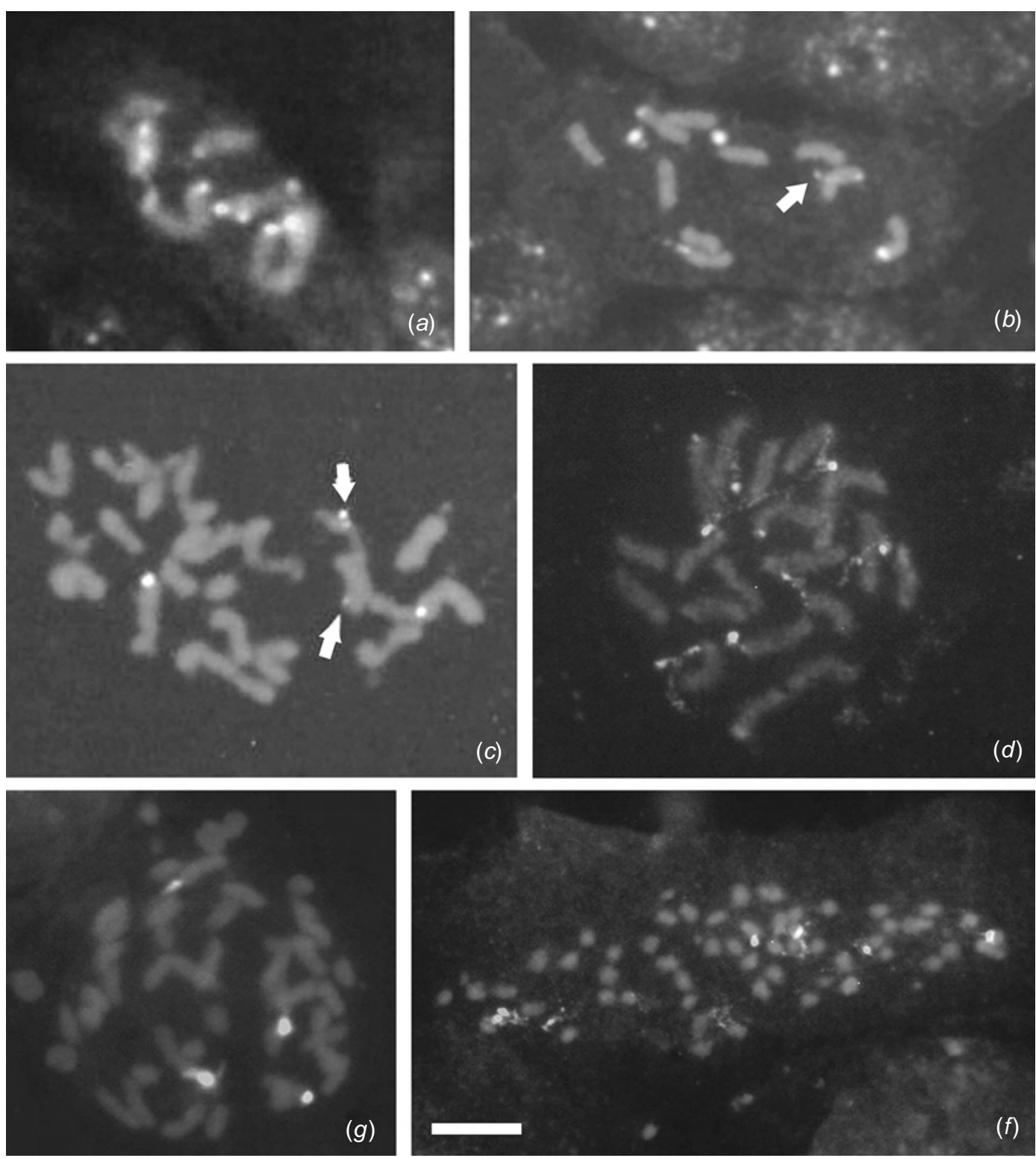

Fig. 3. FISH with $45 \mathrm{~S}$ rDNA probe in species of Eleocharis. (a) E. flavescens $(2 n=10)$ with $10 \mathrm{rDNA}$ sites; $(b)$ E. maculosa $(2 n=10)$, showing six rDNA sites, two being minor and four major; the arrows point to the minor sites; note also the spread out aspect at prometaphases; (c) E. geniculata $(2 n=20)$, showing four hybridisation sites; arrows point to the two minor rDNA sites; $(d)$ E. sellowiana $(2 n=20)$, exhibiting eight rDNA sites; note the spread out aspect of hybridisation sites; $(g)$ E. montana with four rDNA sites; and $(f)$ E. acutangula $(2 n=54)$, showing eight $45 \mathrm{~S}$ rDNA sites. Scale $\mathrm{bar}=5 \mu \mathrm{m}$. 
in chromosome organisation in Eleocharis, whereas AT-rich segments represent a repetitive DNA family that perhaps appears sporadically in a few species, with a punctual importance. Sheikh and Kondo (1995) used chromosome banding to study the karyotypical differences in Drosera (Droseraceae), another group containing holocentric chromosomes. These authors found that in 12 species, the bands appeared preferentially in the terminal chromosome positions, but with accumulation of CMA-positive and not DAPI-positive bands, as observed here in Eleocharis. In contrast to our results, there are two published examples of GC- and AT-rich heterocromatin accumulation. In the first case, Vanzela and Guerra (2000) described three heterochromatin types in the genus Rhynchospora (Cyperaceae), i.e. $\mathrm{CMA}_{3}{ }^{+} / \mathrm{DAPI}^{-}, \mathrm{CMA}_{3}{ }^{+} / \mathrm{DAPI}^{+}$, and $\mathrm{CMA}_{3}{ }^{-} / \mathrm{DAPI}^{+}$, which varied in size and position; however, only the karyotype of $R$. globosa was differentiated owing to accumulation of AT-rich blocks. In the second case, Guerra and García (2004) described a large amount of heterochromatin (more AT- than GC-rich bands) in Cuscuta approximata (Cuscutaceae). In fact, the accumulation and distribution of heterochromatin in holocentric chromosomes seems to be very similar to that known for monocentric chromosomes (Guerra 2000).

The common association among terminal GC-rich blocks with nucleolar organiser regions was previously shown in other Cyperaceae, including Carex (Greilhuber 1995) and Rhynchospora (Vanzela and Guerra 2000). However, on the basis of the species investigated here, the association between GC-rich heterochromatin and NOR is not a rule. Thus, these data suggest the occurrence of at least two repetitive DNA families in Eleocharis: (1) $\mathrm{C}-\mathrm{CMA}_{3}{ }^{+}$bands NOR associated and (2) $\mathrm{C}_{-} \mathrm{CMA}_{3}{ }^{+}$not NOR associated. Nucleolar constrictions are not frequently visualised on holocentric chromosomes, and following this tendency, only a few chromosomes with satellites (terminal NORs) were seen in Eleocharis. These terminal constrictions were found in E. radicans $(2 n=10)$, E. sellowiana with $2 n=20$ and E. acutangula with $2 n=54$ (Fig. $1 e, h, m$ ). Similar constrictions were also described by Hoshino (1987) in Eleocharis and by Vanzela et al. (1996) and Luceño et al. (1998) in Rhynchospora.

To confirm the number of NORs, FISH with 45S rDNA probe was performed. The $\mathrm{p} T a 71$ probe localised hybridisation sites always at the chromosome ends, as previously reported by Vanzela et al. (1998) in Rhynchospora, by Furuta and Hoshino (1999) in E. mamillata var. cyclocarpa and by Guerra and García (2004) in C. approximata (Cuscutaceae). These latter authors hybridised chromosomes with 18S rDNA probes and found 12 terminal hybridisation sites, with two small chromosomes with rDNA sites at both extremities. The results of FISH with the 45S rDNA probe, according to our study, also showed multiple and terminal hybridisation sites, and that the differences in hybridisation site number were independent of the ploidy level. The hybridisation sites appear spread out at prometaphase and metaphase, hindering determination of the number of sites. Ten $45 \mathrm{~S}$ rDNA sites were found in E. flavescens with $2 n=10$ (Fig. $3 a$ ), in which only four are associated to the GC-rich heterochromatin. In E. maculosa $(2 n=10)$, six rDNA sites were observed, two being minor and four major (Fig. 3b), and these four are associated with GC-rich blocks. E. geniculata $(2 n=20)$ showed four hybridisation sites (Fig. 3c). E. sellowiana $(2 n=20)$ showed eight rDNA sites (Fig. $3 d$ ), and all associated with GC-rich blocks. E. montana $(2 n=40)$ exhibited four rDNA sites (Fig. 3e), with two associated with GC-rich heterochromatin. E. acutangula $(2 n=54)$ showed eight $45 \mathrm{~S}$ rDNA sites (Fig. $3 f)$ and a larger number of GC-rich blocks. The multiplicity of $45 \mathrm{~S}$ rDNA sites and the occurrence of two heterochromatin types (GC-rich associated and not associated with NOR) observed in Eleocharis, were also reported in Rhynchospora by Vanzela et al. (1998), suggesting a cytogenetical feature common for Cyperaceae.

In conclusion, these results show that despite of the reduction in the number of morphological and cytogenetical features (considering the absence of primary constrictions), the karyotypes of Eleocharis accumulate differences in the size and number of chromosomes between species and populations as well as in the size and number of GC-rich bands and 45S rDNA sites. Hence, cytogenetics can be considered a good tool for taxonomic and evolutionary studies in Cyperaceae.

\section{Acknowledgements}

This study was supported by Brazilian agencies CAPES, CNPq and Fundação Araucária.

\section{References}

Bir SS, Cheema P, Sidhu M (1992) Chromosomal analysis of Fimbristylis Vahl in Punjab, North West India. Proceedings of the Indian Academy of Sciences B58 1, 63-70.

Bureš P, Rotreklová O, Holt SDS, Pikner R (2004) Cytogeographical survey of Eleocharis subser. Eleocharis in Europe. 1. Eleocharis palustris. Folia Geobotanica 39, 235-257.

Da Silva CRM, González-Elizondo MS, Vanzela ALL (2005) Reduction of chromosome number in Eleocharis subarticulata (Cyperaceae) by multiple translocations. Botanical Journal of the Linnean Society 149, 457-464. doi: 10.1111/j.1095-8339.2005.00449.x

Davies EW (1956) Cytology, evolution and origin of the aneuploid series in the genus Carex. Hereditas 42, 349-365.

Faria AD (1998) O gênero Eleocharis R.Br. (Cyperaceae) no Estado de São Paulo. Mestrado em Biologia Vegetal. Unicamp, Campinas, São Paulo, Brasil. p. 150.

Faulkner JS (1972) Chromosome studies on Carex section Acutae in northwest Europe. Botanical Journal of the Linnean Society 65, 271-301.

Furuta K, Hoshino T (1999) Localization of the 18S and 5S rDNA on the chromosomes with non-localized centromere in Cyperaceae. In 'XVI international botanical congress, St Louis, MI, USA’. Abstract No. 4331, Poster No. 1829.

Gerlach WL, Bedbrook JR (1979) Cloning and characterization of ribosomal RNA genes from wheat and barley. Nucleic Acids Research 7, 1869-1885. doi: 10.1093/nar/7.7.1869

González-Elizondo MS, Peterson PM (1997) A classification of and key to the supraspecific taxa in Eleocharis (Cyperaceae). Taxon 46, 433-449. doi: $10.2307 / 1224386$

González-Elizondo MS, Tena-Flores J, Alarcón-Herrera T, Flores-Tavizón E, Barajas-Acosta N (2005) An arsenic tolerant new species of Eleocharis (Cyperaceae) from Chihuahua, Mexico. Brittonia 57(2), 150-154. doi: 10.1663/0007-196X(2005)057[0150:AANSOE]2.0.CO;2

Greilhuber J (1995) Chromosomes of the monocotyledons (general aspects). In 'Monocotyledons: systematics and evolution'. (Eds PJ Randall, PJ Cribb, DF Cutler, CJ Humphries) pp. 379-414. (Royal Botanic Gardens, Kew: London)

Guerra M (2000) Patterns of heterochromatin distribution in plant chromosomes. Genetics and Molecular Biology 23, 1029-1041. 
Guerra M, García MA (2004) Heterochromatin and rDNA sites distribution in the holocentric chromosomes of Cuscuta approximata Bab. (Convolvulaceae). Genome 47, 134-140. doi: 10.1139/g03-098

Guerra M, Brasileiro-Vidal AC, Arana P, Puertas MJ (2005) Mitotic microtubule development and histone $\mathrm{H} 3$ phosphorylation in the holocentric chromosomes of Rhynchospora tenuis (Cyperaceae). Genetica 126, 1-9.

Håkansson A (1954) Meiosis and pollen mitosis in X-rayed and untreated spikelets of Eleocharis palustris. Hereditas 40, 325-345.

Harriman NA (1981) Chromosome number reports LXXI. Taxon 30, 517.

Heiser CBJr (1979) The totora (Scirpus californicus) in Ecuador and Peru. Economic Botany 32, 222-236.

Hoshino T (1987) Karyomorphological studies on 6 taxa of Eleocharis in Japan. Bulletin of the Okayama University of Science 22, 305-312.

Jankun A (1989) Further studies in chromosome numbers of Polish angiosperms. Part XXII. Acta Biologia Cracoviensia Series Botanica 31, 1-17.

Kondo K, Sheikh SA, Hoshi Y (1994) New finding of another $2 n=6$ species in the angiosperms, Drosera roseana Marchant. Chromosome Service 57, $3-4$.

Kukkonen I(1990) On the genus Eleocharis (Cyperaceae) in the Flora Iranica area, with revised infrageneric classification and nomenclature. Annales Botanici Fennici 27, 109-117.

Löve A, Löve D (1981) In IOPB chromosome number reports LXXIII. Taxon 30, 845-851.

Löve A, Löve D, Raymond M (1957) Cytotaxonomy of Carex section Cappilares. Canadian Journal of Botany 35, 715-761.

Luceño M, Vanzela ALL, Guerra M (1998) Cytotaxonomic studies in Brazilian Rhynchospora (Cyperaceae), a genus exhibiting holocentric chromosomes. Canadian Journal of Botany 76, 440-449. doi: $10.1139 / \mathrm{cjb}-76-3-440$

Nijalingappa BHM (1973) Cytological studies in Eleocharis. Caryologia 26, 513-520.

Nordenskiöld H (1951) Cyto-taxonomical studies in the genus Luzula. I. Somatic chromosomes e chromosome numbers. Hereditas 37, 325-355.

Ohkawa T, Yokota M, Hoshino T (2000) Aneuploidal population differentiation in Carex sociata Boott (Cyperaceae) of the Ryukyu Islands, Japan. Botanical Journal of the Linnean Society 132, 337-358. doi: 10.1006/boj1.1999.0303

Pignotti L, Fiorini G (1998) Mediterranean chromosome number reports 8 (899-904). Flora Mediterranea 8, 214-221.

Rath SP, Patnaik SN (1978) Cytological studies in Cyperaceae. Proceedings of the Indian Science Congress Association (III, C) 65, 107-108.

Roalson EH, Friar EA (2000) Infrageneric classification of Eleocharis (Cyperaceae) revisited: evidence from the internal transcribed spacer (ITS) region of nuclear ribosomal DNA. Systematic Botany 25, 323-336. doi: 10.2307/2666645
Schwarzacher TP, Ambros P, Schweizer D (1980) Application of giemsa banding to orchid karyotype analysis. Plant Systematics and Evolution 134, 293-297. doi: 10.1007/BF00986805

Sheikh SA, Kondo K (1995) Differential staining with orcein, giemsa CMA, and DAPI for comparative chromosome study of 12 species of Australian Drosera (Droseraceae). American Journal of Botany 82, 1278-1286. doi: $10.2307 / 2446251$

Strandhede SO (1964) Chromosome studies in Eleocharis subser. Palustres. I. Meiosis in some forms with 15 chromosomes. Hereditas 53, 47-62.

Strandhede SO (1965) Chromosome studies in Eleocharis, subser. Palustres. Opera Botanica 9(2), 1-86.

Subramanian D (1988) Cytotaxonomical studies in south Indian Cyperaceae. I. Species from the plains. Cytologia 53, 67-72.

Svenson HK (1929) Contributions from the Gray Herbarium of Harvard University. LXXXVI. Monographic studies in the genus Eleocharis. Rhodora 31, 121-245.

Svenson HK (1932) Monographic studies in the genus Eleocharis. II. Rhodora 34, 193-230.

Svenson HK (1934) Monographic studies in the genus Eleocharis. III. Rhodora 36, 377-408.

Svenson HK (1937) Monographic studies in the genus Eleocharis. IV. Rhodora 39, 219-279.

Svenson HK (1939) Monographic studies in the genus Eleocharis V. Rhodora 41, 1-110.

Vanzela ALL, Guerra M (2000) Heterochromatin differentiation in holocentric chromosomes of Rhynchospora (Cyperaceae). Genetics and Molecular Biology 23, 453-456. doi: $10.1590 / \mathrm{S} 1415-47572000000200034$

Vanzela ALL, Guerra M, Luceño M (1996) Rhynchospora tenuis Link (Cyperaceae), a species with the lowest number of holocentric chromosomes $(n=2)$. Cytobios 88, 219-228.

Vanzela ALL, Cuadrado A, Jouve N, Luceño M, Guerra M (1998) Multiple locations of the rDNA in species of Rhynchospora (Cyperaceae). Chromosome Research 6, 345-349. doi: 10.1023/A:1009279912631

Vanzela ALL, Luceño M, Guerra M (2000) Karyotype evolution and cytotaxonomy in Brazilian species of Rhynchospora Vahl (Cyperaceae). Botanical Journal of the Linnean Society 134, 557-566. doi: 10.1006/boj1.2000.0352

Yano O, Katsuyama T, Tsubota H, Hoshino T (2004) Molecular phylogeny of Japanese Eleocharis (Cyperaceae) based on ITS sequence data, and chromosomal evolution. Journal of Plant Research 117, 409-419. doi: 10.1007/s10265-004-0173-3

Manuscript received 1 February 2007, accepted 9 October 2007 


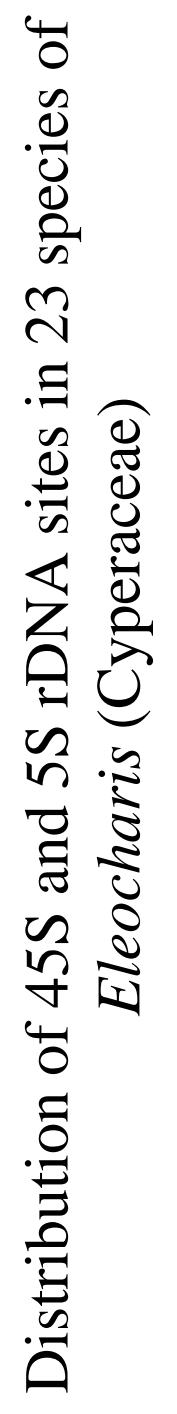




\section{Editorial Manager(tm) for Genetica \\ Manuscript Draft}

Manuscript Number:

Title: Distribution of 45S and 5S rDNA sites in 23 species of Eleocharis (Cyperaceae)

Article Type: Original Research

Keywords: FISH, holocentric chromosomes, rDNA distribution, amplification and location

Corresponding Author: andré luís laforga vanzela, Dr.

Corresponding Author's Institution: Universidade Estadual de Londrina

First Author: andré luís laforga vanzela, Dr.

Order of Authors: andré luís laforga vanzela, Dr.

Abstract: Studies of rDNA location in holocentric chromosomes of Cyperaceae are scarce, but a few reports have indicated the predominance of 45S rDNA in terminal positions, multiple numbers of sites and a decondensed state of hybridization region in prometaphase/metaphase. To increase the knowledge of the number 45S and 5S rDNA sites and distribution in holocentric chromosomes of Cyperaceae, 23 Brazilian species of Eleocharis were studied. FISH showed 45S rDNA signals always located in terminal regions, which varied from two (E. bonariensis with $2 \mathrm{n}=20$ ) to ten (E. flavescens with $2 \mathrm{n}=10$ and E. laeviglumis with $2 \mathrm{n}=60$ ). The $5 \mathrm{~S}$ rDNA showed less variation, with 16 species exhibiting two sites and 7 species with four sites, preferentially in terminal positions, except for 4 species (E. subarticulata, E. flavescens, E. sellowiana and E. geniculata) that showed interstitial sites. Results are discussed in order to understand the prevalence of terminal rDNA sites, the mechanisms involved in the interstitial allocation of 5S rDNA sites and the events of amplification and dispersion of 45S rDNA. 
1 Distribution of $45 \mathrm{~S}$ and $5 \mathrm{~S}$ rDNA sites in 23 species of 2 Eleocharis (Cyperaceae)

4 Carlos Roberto Maximiano da Silva ${ }^{1}$ and André Luís Laforga Vanzela ${ }^{2}$

5 Pós-graduação em Genética, Instituto de Biociências, Letras e Ciências Exatas, 6 UNESP, 15054-000, São José do Rio Preto, SP, Brazil.

7 Laboratório de Biodiversidade e Restauração de Ecossistemas, Departamento de 8 Biologia Geral, CCB, Universidade Estadual de Londrina, 86051-970, Londrina, PR, 9 Brazil. Correspondent author: andrevanzela@uel.br

\section{Abstract}

12 Studies of rDNA location in holocentric chromosomes of Cyperaceae are scarce, but a 13 few reports have indicated the predominance of $45 \mathrm{~S}$ rDNA in terminal positions, 14 multiple numbers of sites and a decondensed state of hybridization region in 15 prometaphase/metaphase. To increase the knowledge of the number 45S and 5S rDNA 16 sites and distribution in holocentric chromosomes of Cyperaceae, 23 Brazilian species 17 of Eleocharis were studied. FISH showed 45S rDNA signals always located in terminal regions, which varied from two (E. bonariensis with $2 n=20)$ to ten (E. flavescens with $2 n=10$ and E. laeviglumis with $2 n=60$ ). The 5S rDNA showed less variation, with 16

20 species exhibiting two sites and 7 species with four sites, preferentially in terminal 21 positions, except for 4 species (E. subarticulata, E. flavescens, E. sellowiana and E. geniculata) that showed interstitial sites. Results are discussed in order to understand

23 the prevalence of terminal rDNA sites, the mechanisms involved in the interstitial 24 allocation of 5S rDNA sites and the events of amplification and dispersion of $45 \mathrm{~S}$ rDNA. 
1 Key words: FISH, holocentric chromosomes, rDNA distribution, amplification and

2 location

3

4 Introduction

The rRNA genes occur as moderately repetitive DNA families on eukaryote

6 genomes. The 45S rDNA of plants, as well as in other organisms, appears as repeated

7 and clustered segments at particular chromosomal positions. These segments

8 predominantly occupy the chromosome ends (Furuta and Kondo 1999; Rego et al.

9 2009), ranging in the number of sites among and within species (Vanzela et al. 1998; De

10 Melo and Guerra 2003; Da Silva et al. 2008a; Raskina et al. 2008). The 5S rDNA is also

11 organized in repeated and clustered segments, occurring in most cases in distinct

12 chromosome positions of those occupied by 45S rDNA (Moscone et al. 1999).

13 Although these segments vary in the number of sites and chromosome pairs in different

14 organisms, they tend to occupy similar chromosome and position in closely related

15 species, as in Aristolochia (Berjano et al. 2009).

16 Plant holocentric chromosomes were reported in all representatives of the

17 families Juncaceae Juss. and Cyperaceae Juss. (Bokhari and Godward 1980; Roalson et

18 al. 2008), in some species of genus Drosera - Droseraceae and subgenus Cuscuta -

19 Cuscutaceae.However, there are two isolated species, Chionographis japonica -

20 Liliaceae and Myristica fragrans Myristicaceae, which present this chromosome type

21 (Flach 1966; Tanaka and Tanaka 1977; Sheikh et al. 1995; García 2001). The locations

22 of rDNA sites have only been determined in a few studies. Multiple 45S rDNA sites

23 were detected in nine species of Rhynchospora (Vanzela et al. 1998, 2003) and seven

24 species of Eleocharis (Da Silva et al. 2005, 2008a, b), both of the Cyperaceae family.

25 Hoshi (1995) and Furuta and Kondo (1999) also reported multiple and terminal rDNA 
1 sites in Drosera. However, in Cuscuta approximata one pair of 45S rDNA and three of

2 5S rDNA sites were reported (Guerra and García 2004). In spite of general tendency

3 towards a terminal location of $45 \mathrm{~S}$ rDNA, the $5 \mathrm{~S}$ rDNA was reported preferentially in

4 interstitial regions in plants and animals, and in Eleocharis the interstitial occurrence of

5 5S rDNA was associated to chromosome rearrangement (Da Silva et al. 2008b).

6 Studies about the amount and distribution of rDNA sites in plants with

7 holocentric chromosomes are scarce. Cyperaceae family possess approximately 5,500

8 species (Govaerts et al. 2007), but less than $1 \%$ of studied species possess rDNA as

9 probed by FISH. These few reports do not discuss the location and amplification of

10 rDNA based in the models, as is commonly done in organisms with monocentric

11 chromosomes. The aim of this study was to localize the 45S and 5S rDNA sites using

12 double-FISH in 23 Brazilian species of Eleocharis containing different chromosome

13 number and size. Data were discussed to assess the karyotype diversity involving the

14 rDNA sites and to understand the possible mechanisms that are operating in the rDNA

15 amplification and distribution in organisms with holocentric chromosomes.

\section{Material and Methods}

18 Three individuals of each of 23 species of Eleocharis were collected in different

19 Brazilian states (Table 1). Samples were cultivated in a greenhouse at the Laboratório

20 de Biodiversidade e Restauração de Ecossistemas (LABRE) at Universidade Estadual

21 de Londrina, Paraná, Brazil. Vouchers were deposited at the ICN herbarium of the

22 Universidade Federal do Rio Grande do Sul, Porto Alegre, Brazil (Table 1). Metaphase

23 cells were obtained from root tips pre-treated with $2 \mathrm{mM}$ 8-hydroxyquinolin for $24 \mathrm{~h}$,

24 fixed in ethanol:acetic acid (3:1, v:v) for $24 \mathrm{~h}$, and stored at $-20{ }^{\circ} \mathrm{C}$. Samples were 
1 softened in $4 \%$ cellulase plus $40 \%$ pectinase (w:v) at $37^{\circ} \mathrm{C}$ for $4 \mathrm{~h}$, squashed in a drop

2 of $60 \%$ acetic acid, and the cover slips were removed after freezing in liquid nitrogen. Fluorescent in situ hybridization (FISH) was performed as described in Da Silva

4 et al. (2008a). The 45S rDNA probe (pTa71) from Triticum aestivum was labeled with 5 digoxigenin-11-dUTP and the 5S rDNA probe from Rhynchospora pubera (Angeles 6 Cuadrado, unpublished) was labeled with biotin-14-dATP, both by nick translation. 7 Probes were simultaneously utilized for FISH in a mixture of $30 \mu \mathrm{L}$ containing $100 \%$ 8 formamide $(15 \mu \mathrm{L}), 50 \%$ polyethylene glycol $(6 \mu \mathrm{L}), 20 \times \operatorname{SSC}(3 \mu \mathrm{L}), 100 \mathrm{ng}$ of calf

9 thymus DNA $(1 \mu \mathrm{L}), 10 \% \operatorname{SDS}(1 \mu \mathrm{L})$, and $200 \mathrm{ng}$ of probes $(4 \mu \mathrm{L}$ each). The material 10 was denatured at $90{ }^{\circ} \mathrm{C}$ for $10 \mathrm{~min}$ and hybridization was performed at $37{ }^{\circ} \mathrm{C}$ overnight 11 in a humidified chamber. Post-hybridization washes were carried out with $70 \%$ 12 stringency, using baths with SSC buffer. The probes were simultaneously detected with avidin-FITC and anti14 digoxigenin-rhodamine conjugates. The post-detection washes were performed in $4 \times$ $15 \mathrm{SSC} / 0.2 \%$ Tween 20 , all at room temperature. Slides were mounted with $25 \mu \mathrm{L}$ of 16 DABCO solution, composed of glycerol (90\%), 1,4-diaza-bicyclo(2,2,2)-octane (2.3\%), $1720 \mathrm{mM}$ TrisHCl, $\mathrm{pH} 8.0(2 \%), 2.5 \mathrm{mM} \mathrm{MgCl} 2$ (4\%) and distilled water (1.7\%), plus 4 $18 \mu \mathrm{l}$ of $2 \mu \mathrm{g} \cdot \mathrm{mL}^{-1}$ DAPI.

All the chromosome images were acquired separately without color (grayscale) 20 with a Leica DM 4500 B microscope coupled with a DFC 300FX camera and 21 overlapped with red color for DAPI, white for rhodamine (45S rDNA) and greenish22 yellow (5S rDNA) for FITC, using the Leica IM50 4.0 software. The images were 23 optimized for best contrast and brightness with Adobe Photoshop CS3 version 10.0 24 software. 


\section{Results}

Twenty-three species were analyzed (among these, 15 belonged to the subgenus

4 Eleocharis, two to Scirpidium and six to Limnochloa) according to González-Elizondo 5 and Peterson (1997) (Table 1). The number of 45S rDNA sites varied from two to ten

6 independent of chromosome numbers and subgenus. In contrast, terminal location of 7 45S rDNA was constant in all species. The 5S rDNA probe showed a minor variation 8 when compared to $45 \mathrm{~S}$ rDNA, ranging from two to four chromosome sites which were 9 terminal in 19 species and interstitial in four others (Table 1). The rDNA hybridization 10 signals also varied in size among homologous, as observed in E. niederleinii (Fig. 1c), 11 E. montana (Fig. 1g), E. debilis (Fig. 2f) and E. obtusetrigona (Fig. 3b). In all cases, the $1245 \mathrm{~S}$ rDNA appeared diffused/decondensed and different of the 5S rDNA probed, even 13 when they were located in the terminal region.

The representatives of subgenus Eleocharis showed no correspondence between polyploidy level and rDNA site numbers. Eleocharis flavescens, with $2 n=10$, exhibited 16 signals of $45 \mathrm{~S}$ rDNA in all chromosomes of the complement and only one interstitial $5 \mathrm{~S}$ 17 rDNA signals located in pair 1 (Fig. 1k), while E. nana with $2 n=20$, showed two terminal signals of each of $45 \mathrm{~S}$ and $5 \mathrm{~S}$ rDNA (Fig. 1b). Two interstitial signals of 5S rDNA were also found in E. subarticulata $(2 n=6)$, E. sellowiana and E. geniculata,

20 but, in these latter two species, karyotypes with $2 n=10$ and 20 were found. These 21 species also showed variations in the number of terminal 45S rDNA sites, being four in 22 E. subarticulata (Fig. 1f), in the diploid and polyploid of E. geniculata (Figs. 2c and d), 23 and in the diploid form of E. sellowiana and eight in the polyploid form of $E$. 24 sellowiana (Figs. 2a and b). Eleocharis contracta (Fig. 1a), E. niederleinii (Fig. 1c), E. 25 loefgreniana (Fig. 1d), E. viridans (Fig. 1e), E. montana (Fig. 1g), E. minima (Fig. 1h), 
1 E. filiculmis (Fig. 1i), E. capillacea (Fig. 1j), E. maculosa (Fig. 11) and E. debilis (Fig.

2 2f) exhibited distinct chromosome numbers but equal rDNA site numbers of rDNA

3 sites, being four signals to $45 \mathrm{~S}$ rDNA and two to $5 \mathrm{~S}$, always in terminal position (Table $4 \quad 1)$.

The two species of the subgenus Scirpidium varied in number and position of 6 rDNA sites. Eleocharis bonarienesis with $2 n=20$ showed four $45 \mathrm{~S}$ rDNA sites and 7 four signals of $5 \mathrm{~S}$ rDNA, always in terminal positions (Fig. 2g), while Eleocharis sp., 8 with $2 n=10$ (a new species cited in Da Silva et al. 2010, but yet undetermined) showed 9 six chromosomes with 45S rDNA signals and another two with 5S rDNA, also always 10 in terminal positions (Fig. 2e).

11 Six species of the subgenus Limnochloa were studied. These species showed 12 different chromosome number (40, 50, 52, 54 and 60) and exhibited the smallest 13 chromosomes of the genus. Four 5S rDNA terminal sites were found in all species but 14 the number of terminal 45S rDNA sites varied. Eleocharis obtusetrigona, E. acutangula 15 and E. interstincta presented eight hybridization signals (Figs. 3b, d and e), while $E$. 16 plicarhachis, E. liesneri and E. laeviglumis showed 10 sites (Figs. 3a, c and f).

Discussion

Cyperaceae is marked by a high variability in chromosome number (Roalson 20 2008), provoked mainly by events of symploidy (fusion), agmatoploidy (fission) and 21 polyploidy (Håkanson 1958; Vanzela et al. 2000; Yano et al. 2004; Hipp et al. 2009).

22 The basic chromosome number, $x=5$, proposed by Löve et al. (1957) for Cyperaceae is 23 accepted by several authors (Vanzela et al. 1998; Yano et al. 2004; Da Silva et al. 24 2008a), even considering the high numeric variability. In the context of $45 \mathrm{~S}$ rDNA sites, 25 it would be natural to expect that the karyotypes with few chromosomes would also 
1 present few rDNA sites. However, we found species with $2 n=10$ with four signals (the

2 majority of species), six signals (Eleocharis sp.) and signals in all chromosomes, such

3 as in E. flavescens. Multiple hybridization sites were previously reported to Eleocharis

4 flavescens (Da Silva et al. 2008a), as well as in some species of Rhynchospora (Vanzela

5 et al. 1998) and Drosera (Hoshi 1995).

6 In this sense, the polyploids should have the double the number of sites in

7 relation to their diploid representatives, as reported in Rhynchospora tenuis with $2 n=4$

8 and $2 n=8$, containing two and four 45S rDNA sites, respectively (Vanzela et al. 2003).

9 This was also observed in E. sellowiana (with four and eight 45S rDNA signals). On the

10 other hand, Eleocharis geniculata exhibited the same number of sites in both $2 n=10$

11 and $2 n=20$. The remainding polyploid species with $2 n=20,30$ and 40 showed two and

12 four $45 \mathrm{~S}$ rDNA signals, as did some diploid species (see Table 1). Fissions could

13 explain the relationship between the reduction of $45 \mathrm{~S}$ rDNA sites number and increase

14 of chromosome number, but, there is no a conclusive evidence of such events in these

15 mentioned cases. Thus, the most likely explanation would a loss of sites due to the

16 diploidization process, as proposed by Leitch and Bennett (1997). Similar events were

17 reported in Passiflora (De Melo and Guerra 2003).

18 Species of subgenus Limnochloa presented karyotypes with many and small

19 chromosomes and little variation in size among then. Yano et al. (2004) and Da Silva et

20 al. (2008a) have proposed that these karyotypes may have been generated by

21 chromosome fission, but it was not confirmed in the later study of Da Silva et al.

22 (2010). We found here that karyotypes of Limnochloa had multiple 45S rDNA sites

23 (eight and ten). When we compared the FISH data in relation to karyotype organization,

24 as chromosome number and symmetry (see Da Silva et al. 2010), regardless of 25 systematic arrangement, it was possible to detect that the species with more symmetrical 
1 karyotype, as in E. interstincta (Limnochloa), Eleocharis sp. (Scirpidium), E. flavescens

2 and E. sellowiana (both of subgenus Eleocharis), exhibited a greater number of $45 \mathrm{~S}$

3 rDNA sites. The karyotypes with a greater difference in chromosome sizes, i.e. more

4 asymmetric, as E. montana, E. nana and E. viridians (all of subgenus Eleocharis),

5 showed lower 45S rDNA sites.

6 Cases of multiple 45S rDNA sites have been described in both plants with

7 holocentric chromosomes (Vanzela et al. 1998) and in plants with monocentric ones

8 (Hasterok and Maluszynska 2000; Lim et al. 2001; Kwon and Kim 2009). Some

9 mechanisms of amplification/dispersion of repetitive DNA have been proposed or

10 mentioned for the monocentric system: i) rDNA sites mobility is associated with co-

11 location and activity of transposable elements (Shubert and Wobus 1985; Raskina et al.

12 2008) and ii) equilocal dispersion of heterochromatin and rDNA (Schweizer and Loidl

13 1987; Pederson and Linde-Laursen 1994, respectively). In relation to first model, there

14 are no reports in the literature involving the distribution of transposable elements in

15 plant holocentric chromosomes. For the second model, however, Guerra (2000)

16 interpreted that the equidistribution of repetitive DNA may depend on some structural

17 or functional similarity of each chromosomal region. In this sense the polarization of

18 rDNA sites observed in the interphase some Rhynchospora species might be due to an

19 association of active sites building a single nucleolus (Vanzela et al. 1998). Similarly,

20 the grouping of $45 \mathrm{~S}$ rDNA regions depending on the NOR activity could contribute to

21 the accumulation/dispersion of $45 \mathrm{~S}$ rDNA segments to the chromosome ends with

22 similar size. This could explain the occurrence of multiple rDNA sites preferably in

23 karyotypes whose chromosomes have the same size (symmetrical). Idiograms and

24 chromosome measurements showing the karyotype symmetry/asymmetry are detailed in

25 Da Silva et al (2010). 
The 5S rDNA probe hybridized in different regions of the 45S rDNA sites. The

2 occurrence of $45 \mathrm{~S}$ (terminal) and 5S rDNA (interstitial) sites in the same chromosome

3 pair was found in E. flavescens, precisely because the 45S rDNA sites were distributed

4 in the terminal regions of all chromosomes. The $5 \mathrm{~S}$ hybridization signals were also

5 detected in interstitial positions in E. sellowiana, E. geniculata, E. subarticulata and E.

6 maculosa, but, in last two species the karyotypes with $2 n=6$ and $2 n=8,7$ and 6 were

7 originated after chromosome rearrangements (Da Silva et al. 2005, 2008, respectively),

8 and could support a reasonable explanation for the interstitial positioning of 5S rDNA.

9 The scientific advance of this article was the comparative analysis in a large

10 number of species, i. e. about $30 \%$ of the Brazilian Eleocharis, with representatives of

11 three subgenera. Our study showed that the $45 \mathrm{~S}$ rDNA is more variable in sites number

12 than $5 \mathrm{~S}$, but it could not state why the $45 \mathrm{~S}$ sites never appeared in interstitial positions,

13 as occurred with the $5 \mathrm{~S}$, since rearrangements are very common in the karyotype

14 differentiation of Cyperaceae. Besides, it was unclear why the events that favor the

15 multiplication and dispersion of $45 \mathrm{~S}$ rDNA did not act in the same direction for $5 \mathrm{~S}$

16 rDNA segments. In the future, efforts should be directed towards the investigation of

17 the following aspects: (i) relationships between the location of $45 \mathrm{~S}$ and $5 \mathrm{~S}$ rDNA sites

18 in other Cyperaceae groups, (ii) functionality of rDNA sites and (iii) relationships

19 between rDNA segments detected by FISH, pseudogenes and transposable elements.

\section{Acknowledgements}

22 The authors would like to thank the Brazilian agencies Fundação Araucária and CNPq

23 by financial support. 


\section{References}

2 Berjano R, Roa F, Talavera S, Guerra M (2009) Cytotaxonomy of diploid and polyploid 3 Aristolochia (Aristolochiaceae) species based on the distribution of CMA/DAPI bands and 5S and 45S rDNA sites. Plant Syst Evol 280: 219-227. doi: $10.1007 / \mathrm{s} 00606-009-0184-6$

6 Bokhari FS, Godward MBE (1980) The ultrastructure of the diffuse kinetochore in $7 \quad$ Luzula nivea. Chromosoma 79: 125-136. doi: 10.1007/BF00328478

8 Da Silva CRM, González-Elizondo MS, Vanzela ALL (2005) Reduction of

Da Silva CRM, González-Elizondo MS, Rego LNAA, Torezan JMD, Vanzela ALL (2008a) Cytogenetical and cytotaxonomical analysis of some Brazilian species of Eleocharis. Aust J Bot 56: 82-90. doi:10.1071/BT070170067-1924/08/010082

Da Silva CRM, González-Elizondo MS, Vanzela ALL (2008b) Chromosome Reduction in Eleocharis maculosa (Cyperaceae). Cytogenetic and Genome Res 122: 175-180. doi: $10.1159 / 000163096$

Da Silva CRM, Trevisan R, González-Elizondo MS, Ferreira JM, Vanzela ALL (2010) Karyotypic diversification and its contribution to the taxonomy of Eleocharis (Cyperaceae) from Brazil. Aust J Bot 58: 1-12. doi: 10.1071/BT091850067$1924 / 10 / 010001$

De Melo NF, Guerra MS (2003) Variability of the 5S and 45S rDNA sites in Passiflora 
1 Flach M (1966) Diffuse centromeres in a dicotyledonous plant. Nature 209: 1369-1370.

2 doi: $10.1038 / 2091369 b 0$

3 Furuta T, Kondo K (1999) Sites of 18S-5.8S-26S rDNA sequences in diffused-

4 centromeric chromosomes of Drosera falconerii. Chromosome Sci 3: 69-73. doi: 00A0408029

6 García MA (2001) A new western Mediterranean species of Cuscuta (Convolvulaceae)

7 confirms the presence of holocentric chromosomes in subgenus Cuscuta. Bot $\mathrm{J}$

$8 \quad$ Linn Soc 135: 169-178. doi: 10.1111/j.1095-8339.2001.tb01089.x

9 González-Elizondo MS, Peterson PM (1997) A classification of and key to the 10 supraspecific taxa in Eleocharis (Cyperaceae). Taxon 46: 433-449. doi: $11 \quad 10.2307 / 1224386$

12 Govaerts R, Simpson DA, Bruhl JJ, Egorova T, Goetghebeur P, Wilson K (2007) World 13 checklist of Cyperaceae, Sedges. Kew: Kew Publishing.

14 Guerra MS (2000) Patterns of heterochromatin distribution in plant chromosomes. 15 Genet. Mol. Biol. 23: 1029-1041. doi: 10.1590/S1415-47572000000400049

16 Guerra MS, García M (2004) Heterochromatin and rDNA sites distribution in the 17 holocentric chromosomes of Cuscuta approximata Bab. (Convolvulaceae). 18 Genome. 47: 134-140. doi: 10.1139/G03-098.

19 Håkansson A (1958) Holocentric chromosomes in Eleocharis. Hereditas 44: 531-540.

20 Hasterok R, Maluszynska J (2000) Cytogenetic markers of Brassica napus L. 21 chromosome. J. Appl. Genet. 41: 1-9.

22 Hipp AL, Rothrock PE, Roalson EH (2009) The evolution of chromosome 23 arrangements in Carex (Cyperaceae). Bot Rev 75: 96-109. doi: 10.1007/s12229008-9022-8 
1 Hoshi Y (1995) Chromosome studies in Drosera, the Droseraceae in connection with

2 possible origin of the basic chromosome number of $x=10$ weel-differentiated in 3 the North-hemisphere. Dissertation. Hiroshima University.

4 Kwon J, Kim B (2009) Localization of 5S and 25S rRNA genes on somatic and meiotic chromosomes in Capsicum species of chili pepper. Mol. Cells 27: 205-209. doi:10.1007/s10059-009-0025-Z

7 Leitch IJ, Bennett MD (1997) Polyploidy in angiosperms. Trend in Plant Science 2: 470-476. doi: 10.1016/S1360-1385(97)01154-0

9 Lim K, Wennekes J, Jong JH, Jacobsen E, Tuyl JM (2001) Karyotype analysis of Lilium 10 longiflorum and Lilium rubellum by chromosome banding and fluorescence in situ 11 hybridization. Genome 44: 911-918. doi:10.1139/gen-44-5-911

12 Löve A, Löve D, Raymond M (1957) Cytotaxonomy of Carex section Cappilares. Can J Bot 35: 715-761.

14 Moscone EA, Klein F, Lambrou M, Fuchs J, Schweizer D (1999) Quantitative 15 karyotyping and dual-color FISH mapping of 5S and 18S-25S rDNA probes in the 16 cultivated Phaseolus species (Leguminosae). Genome 42: 1224-1233. doi: 10.1139/gen-42-6-1224

Pedersen C, Linde-Laursen I (1994) Chromosomal locations of four minor rDNA loci and a marker microsatellite sequence in barley. Chrom Res 2: 65-71. doi: 10.1007/BF01539456

Raskina O, Barber JC, Nevo E, Belyayev A (2008) Repetitive DNA and chromosomal rearrangements: speciation-related events in plant genomes. Cytogenet Genome Res 120: 351-357. doi: 10.1159/000121084 
1 Rego LNAA, Da Silva CRM, Torezan JMD, Gaeta ML, Vanzela ALL (2009)

2 Cytotaxonomical study in Brazilian species of Solanum, Lycianthes and Vassobia

3 (Solanaceae). Plant Syst Evol 279: 93-102. doi: 10.1007/s00606-009-0149-9

4 Roalson EH (2008) A synopsis of chromosome number variation in the Cyperaceae. Bot Rev 74: 209-393. doi: 10.1007/s12229-008-9011-y

6 Schweizer D, Loidl J (1987) A model for heterochromatin dispersion and the evolution 7 of C-banded patterns. Chromosom T 9: 61-74.

8 Sheikh SA, Kondo K, Hoshi Y (1995) Study on diffused centromeric nature of Drosera chromosomes. Cytologia 60: 43-47.

10 Schubert I, Wobus U (1985) In situ hybridization confirms jumping nucleolus 11 organizing regions in Allium. Chromosoma 92: 143-148. doi: 10.1007/BF00328466

12 Tanaka N, Tanaka N (1977) Chromosome studies in Chionographis (Liliaceae) I. On 13 the holocentric nature of chromosomes in Chionographis japonica Maxim. $14 \quad$ Cytologia 42: 753-763.

15 Vanzela ALL, Cuadrado A, Jouve N, Luceño M, Guerra M (1998) Multiple locations of 16 the rDNA sites in holocentric chromosomes of Rhynchospora (Cyperaceae). 17 Chromosome Res 6: 345-349. doi: 10.1023/A:1009279912631

18 Vanzela ALL, Luceño M, Guerra M (2000) Karyotype evolution and cytotaxonomy in 19 Brazilian species of Rhynchospora Vahl (Cyperaceae). Bot J Linn Soc 134: 557566. doi: 10.1006/boj1.2000.0352

21 Vanzela ALL, Cuadrado A, Guerra M (2003) Localization of 45S rDNA and telomeric 22 sites on holocentric chromosomes of Rhynchospora tenuis Link (Cyperaceae). Gen Mo Biol 26: 199-201. doi: 10.1590/S1415-47572003000200014 
1 Yano O, Katsuyama T, Tsubota H, Hoshino T (2004) Molecular phylogeny of Japanese

2 Eleocharis (Cyperaceae) based on ITS sequence data, and chromosomal evolution.

3 J Plant Res 117: 409-419. doi: 10.1007/s10265-004-0173-3.

4

\section{$5 \quad$ Legends}

6 Figure 1. Metaphases of Eleocharis species double-probed with 45S rDNA (white) and 7 5S rDNA (greenish-yellow) probes. a) E. contracta $(2 n=20)$ showing four 8 hybridization signals of $45 \mathrm{~S}$ rDNA and two of 5S. b) E. nana $(2 n=20)$ with two signals 9 of each $45 \mathrm{~S}$ and $5 \mathrm{~S}$ rDNA. c) E. niederleinii $(2 n=20)$ with four $45 \mathrm{~S}$ rDNA signals and 10 two for 5S. d) E. loefgreniana $(2 n=20)$. e) E. viridans $(2 n=20)$. f) E. subarticulata $(2 n$ 11 6). g) E. montana $(2 n=40)$. h) E. minima $(2 n=20)$. i) E. filiculmis $(2 n=30)$. j) E. 12 capillacea $(2 n=10)$. d, e, g, h, i, exhibited four $45 \mathrm{~S}$ rDNA and two $5 \mathrm{~S}$ rDNA signals in 13 terminal positions. f) E. subarticulata, exhibited 5S signal in interstitial positions. k) $E$. 14 flavescens $(2 n=10)$ with ten $45 \mathrm{~S}$ rDNA signals and two interstitial $5 \mathrm{~S}$ signals. 1) $E$. 15 maculosa $(2 n=10)$ with four $45 \mathrm{~S}$ rDNA and two 5S. Bar represents $10 \mu \mathrm{m}$.

17 Figure 2. Metaphases of Eleocharis species double-probed with 45S rDNA (white) and 5S rDNA (greenish-yellow) probes. a) E. sellowiana $(2 n=10)$ with four $45 \mathrm{~S}$ rDNA signals and two interstitial $5 \mathrm{~S}$ signals. b) E. sellowiana $(2 n=20)$ with eight $45 \mathrm{~S}$ rDNA signals and two interstitial 5S signals. c and d) E. geniculata $(2 n=10$ and 20) both with

21 four 45S rDNA signals and two interstitial 5S signals, respectively. e) Eleocharis sp.

$22(2 n=10)$ showing six hybridization signals of $45 \mathrm{~S}$ rDNA and two of 5S. f) E. debilis $23(2 n=30)$ with four $45 \mathrm{~S}$ rDNA and two 5S. g) E. bonariensis $(2 n=20)$ with four $45 \mathrm{~S}$ rDNA and four 5S. Bar represents $10 \mu \mathrm{m}$. 
1 Figure 3. Metaphases of subgenus Limnochloa species double-probed with 45S rDNA

2 (white) and 5S rDNA (greenish-yellow) probes. a) E. plicarhachis $(2 n=54)$ showing

3 ten hybridization signals of $45 \mathrm{~S}$ rDNA and four of $5 \mathrm{~S}$. b) E. obtusetrigona $(2 n=52)$

4 with eight hybridization signals of $45 \mathrm{~S}$ rDNA and four of 5S. c) E. liesneri $(2 n=50)$

5 with ten hybridization signals of $45 \mathrm{~S}$ rDNA and four of $5 \mathrm{~S}$. d and e) E. acutangula ( $2 n$

$6=54)$ and $E$. interstincta $(2 n=40)$ both with eight hybridization signals of $45 \mathrm{~S}$ rDNA

7 and four of 5S. f) E. laeviglumis $(2 n=60)$ with ten $45 \mathrm{~S}$ rDNA and four 5S. Bar 8 represents $10 \mu \mathrm{m}$. 


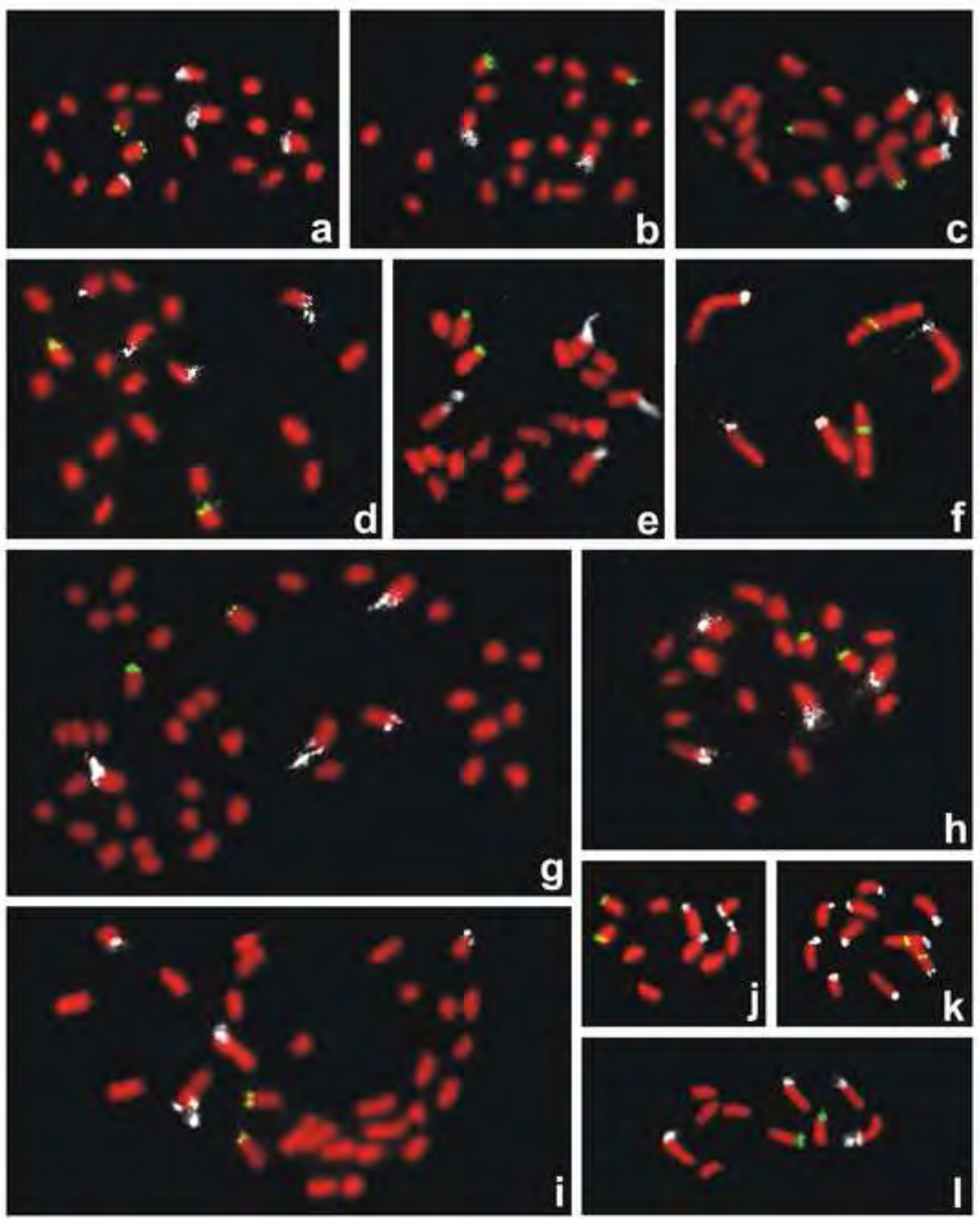



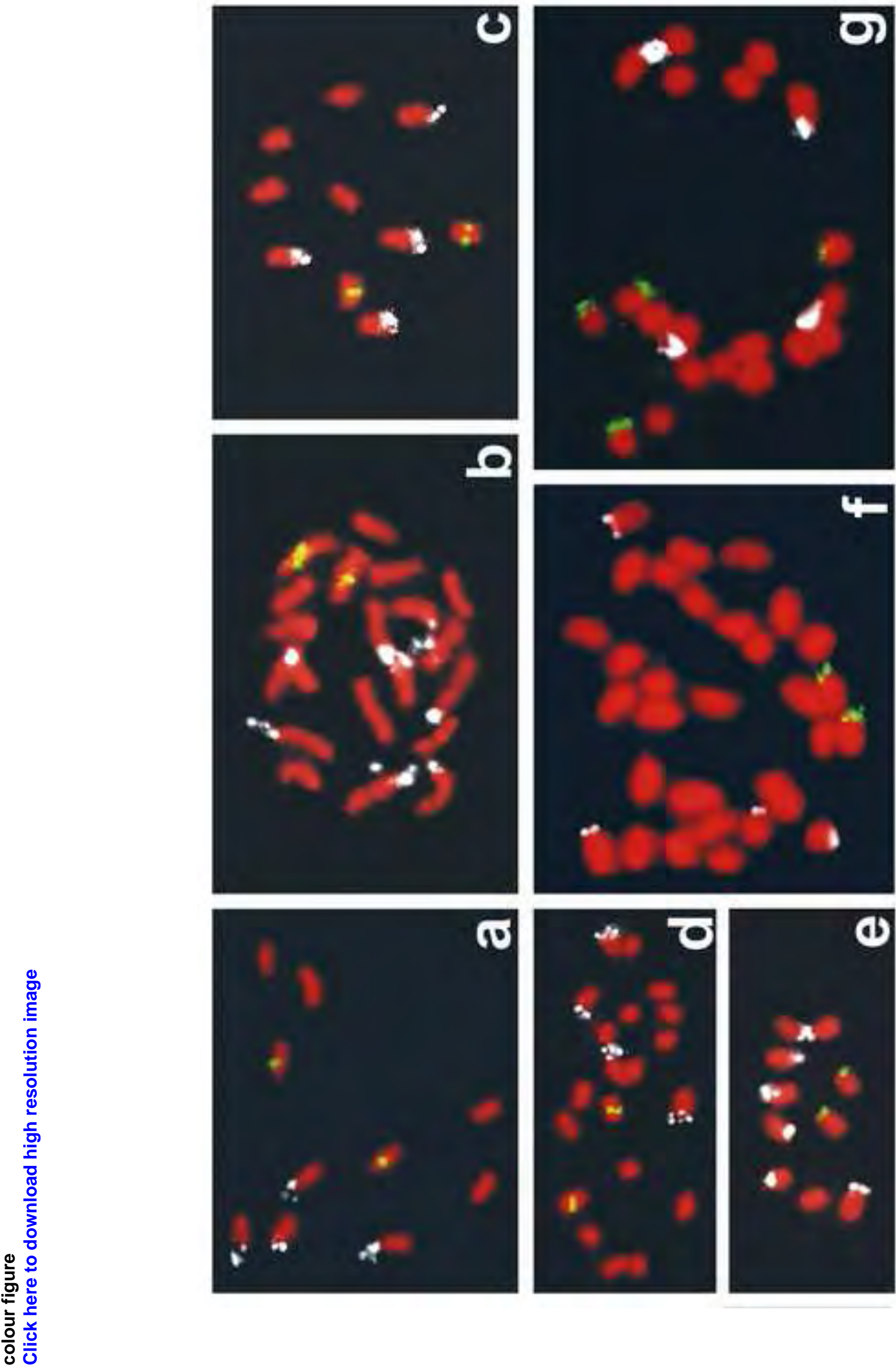

$\frac{g}{6} \frac{5}{8}$ 
colour figure

Click here to download high resolution image
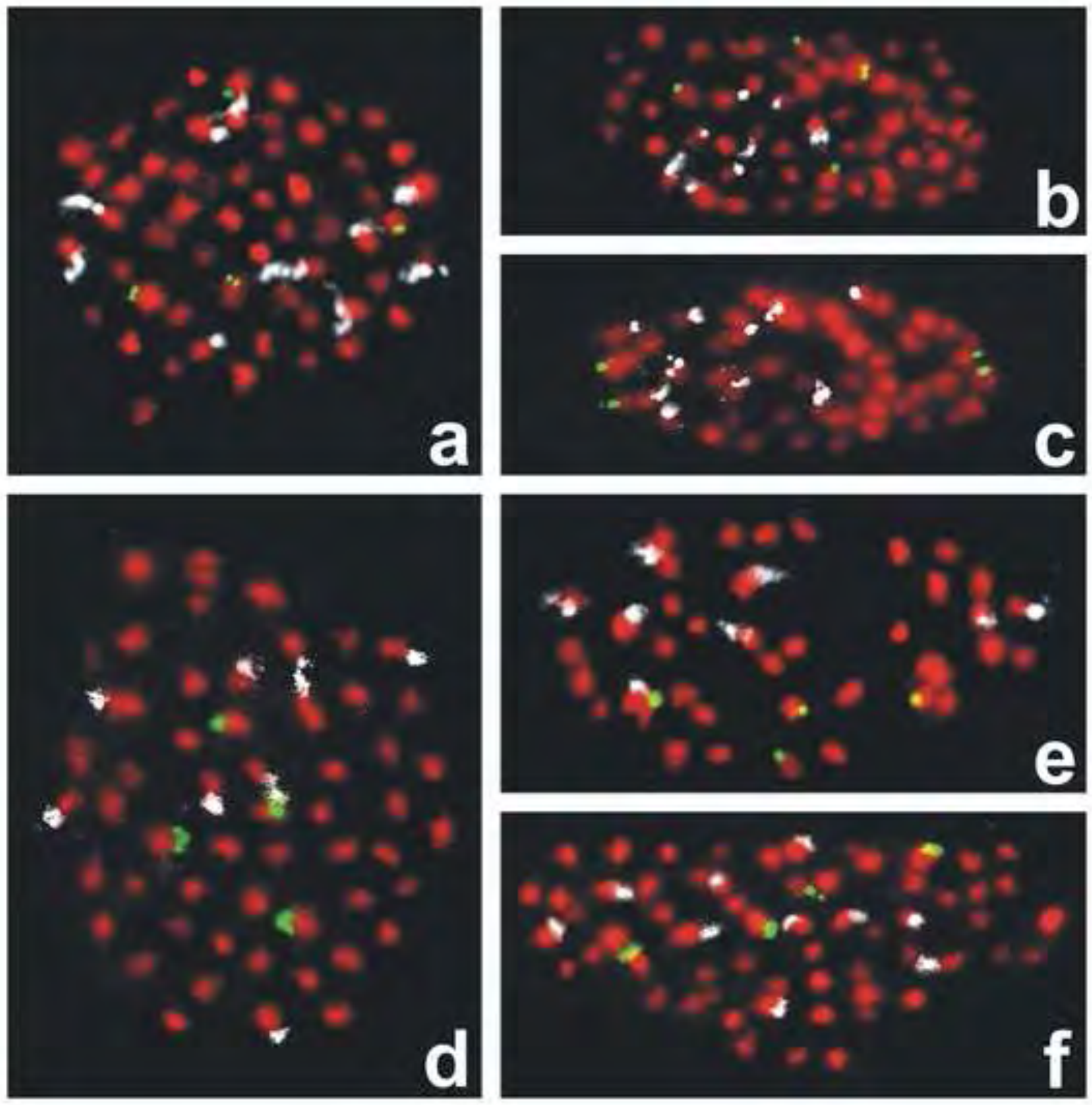


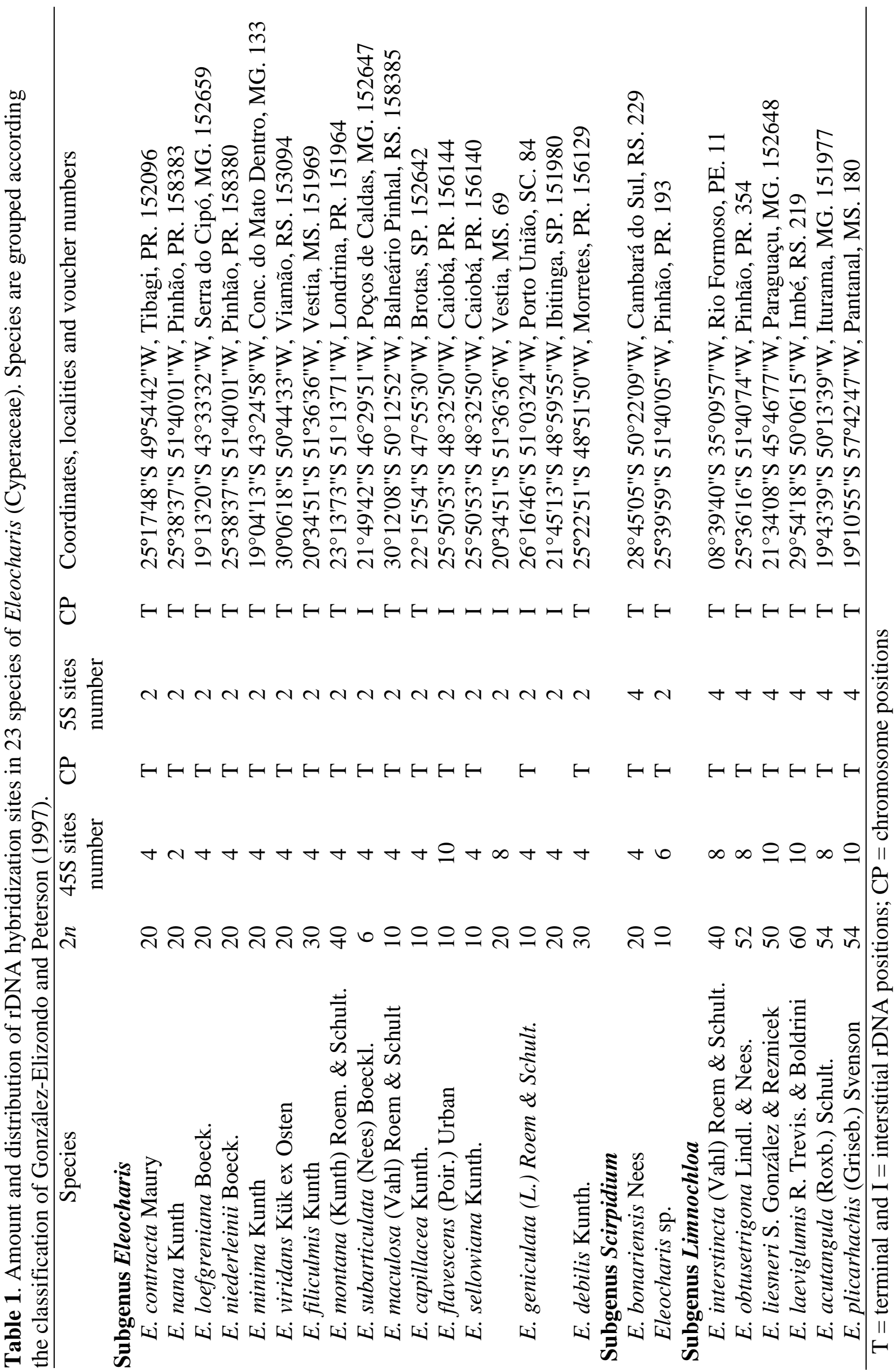




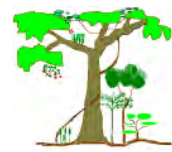

Dear Editor of Genetica

I am submitting the manuscript "Distribution of $45 \mathrm{~S}$ and $5 \mathrm{~S}$ rDNA sites in 23 species of Eleocharis species (Cyperaceae)" of Carlos Roberto Maximiano da Silva and André Luís Laforga Vanzela, to evaluation and possible publication at Genetica.

In this cover letter we cleared the following points:

1. we assured that this article was not submitted for publication in any other journal, book, conference proceedings and printed or digital circulation vehicle;

2. we assured that this study generated only this article and that similar versions were not prepared or submitted to other journals;

3. we also assured that we continued studying this theme and that other studies and articles will be accomplished in continuity to this;

4. we assured that all the consultation sources, as well as financing agency are properly mentioned, and that these do not hurt copyrights;

5. and to conclude, we assured that all of the authors have contributed substantially to the manuscript and approved the final submission.

Best regards,

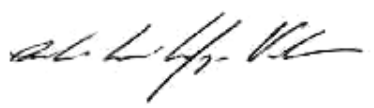

Prof. Dr. André L. L. Vanzela

Laboratório de Biodiversidade e Restauração de Ecossistemas

Departamento de Biologia Geral, CCB, Universidade Estadual de Londrina

Caixa Postal 6001, CEP 86051-990, Londrina, Paraná, Brazil

Fone (Fax): +55 433371 4509, E-mail:andrevanzela@uel.br 
Capítulo 4

Chromosome reduction in Eleocharis maculosa (Cyperaceae)

Artigo publicado na revista Cytogenet Genome Research 2008 122:175-180 


\title{
Chromosome reduction in Eleocharis maculosa (Cyperaceae)
}

\author{
C.R.M. da Silva ${ }^{a, b}$ M.S. González-Elizondo ${ }^{c}$ A.L.L. Vanzela ${ }^{a}$ \\ ${ }^{a}$ Laboratório de Biodiversidade e Restauração de Ecossistemas, Departamento de Biologia Geral, \\ Centro de Ciências Biológicas, Universidade Estadual de Londrina, Londrina, PR; \\ ${ }^{b}$ Instituto de Biociências, Letras e Ciências Exatas, UNESP, São José do Rio Preto, SP (Brazil) \\ ${ }^{\mathrm{c} C I I D I R}$, Instituto Politécnico Nacional, Durango, Dgo. (Mexico)
}

Accepted in revised form for publication by M. Schmid, 11 August 2008.

\begin{abstract}
Chromosome numbers in Cyperaceae lower than the typical basic number $\mathrm{x}=5$ have been described for only three species: Rhynchospora tenuis $(\mathrm{n}=2)$, Fimbristylis umbellaris $(\mathrm{n}=3)$ and Eleocharis subarticulata $(\mathrm{n}=3)$. Eleocharis maculosa is recorded here as the fourth species of Cyperaceae that has a chromosome number lower than $2 \mathrm{n}=10$, with $2 \mathrm{n}=8,7$ and 6 . The karyotype differentiation in E. maculosa was studied using conventional staining (mi-
\end{abstract}

tosis and meiosis), FISH with $45 \mathrm{~S}$ and $5 \mathrm{~S}$ rDNA and telomere probes. The results allow us to determine which chromosomes of the chromosome race with $2 \mathrm{n}=10$ fused to form the remaining reduced numbers, as well as to understand how the symploidy and translocation mechanisms were important in karyotype differentiation and the formation of chromosome races in Eleocharis.

Copyright ( 2008 S. Karger AG, Base
Some plant groups exhibit seemingly conserved karyotypes, with chromosome number, shape and size relatively constant when these are studied by conventional cytogenetics. A good example is the relative similarity among karyotypes of different species of Lobelia, Campanulaceae (Ruas et al., 2001), and Solanum, Solanaceae (Chiarini and Bernardello, 2006). However, in the family Cyperaceae, intraand interspecific karyotype variations associated with chromosome number and size are very common. The occurrence of chromosomes with diffuse kinetochore (holocentric chromosomes) is well known in Cyperaceae. When these chromosomes are broken (agmatoploidy) or fused (symploidy) (Luceño and Guerra, 1996), they continue to be viable in the subsequent cell divisions generating different numbers for the same species. This has been demonstrated in experiments with $\mathrm{X}$ and $\gamma$ irradiation of the chromosomes

This study was supported by the Brazilian agencies Fundação Araucária, CNPq and ProPPG-UEL.

Request reprints from André Luís Laforga Vanzela

Laboratório de Biodiversidade e Restauração de Ecossistemas Departamento de Biologia Geral, Centro de Ciências Biológicas Universidade Estadual de Londrina, Caixa Postal 6001 CEP 86051-990, Londrina, PR (Brazil)

telephone/fax: +55 433371 4509; e-mail: andrevanzela@uel.br of Eleocharis palustris (L.) Roemer and Schultes (Håkanson, 1954) and Rhynchospora pubera (Vahl) Boeck (Vanzela and Colaço, 2002).

Structural rearrangements that culminate in a decrease in chromosome number have been described in different plant groups (Jones, 1998). However, few studies have demonstrated in detail the mechanisms by which such events occur. Among these few cases, we can mention the study of Ikeda (1987) who showed that $\mathrm{n}=2$ in Haplopappus gracilis (Nutt.) A. Gray (Asteraceae) originated by chromosome tandem fusion. Similarly, Lysak et al. (2006) showed a study of chromosome painting where a series of peri- (and para-) centric inversion, followed by reciprocal translocations and meiotic loss of the small product, caused the chromosome number reduction in A. thaliana and other Brassicaceae species. In Cyperaceae, numeric reduction below the more common basic number $(x=5)$ in the family has been reported for three species: Fimbristylis umbellaris (L.) Vahl with $\mathrm{n}=3$ (Rath and Patnaik, 1981), Rhynchospora tenuis Link with two chromosome races, $\mathrm{n}=2$ and 4 (Vanzela et al., 1996) and Eleocharis subarticulata (Nees) Boeck with $\mathrm{n}=3$ (da Silva et al., 2005). However, only the last two studies showed meiotic configurations compatible with reduction in chromosome number that originated by symploidy and multiple translocations, respectively. 
Table 1. Localities of the analyzed populations of Eleocharis maculosa and karyotype features. $2 \mathrm{n}=$ diploid number, DSL $=$ diploid set length, FUEL = voucher number, and GPS = global positioning system, ICN = herbarium of the Universidade Federal do Rio Grande do Sul, Brazil.

\begin{tabular}{|c|c|c|c|}
\hline $2 n$ & $\begin{array}{l}\text { Natural location in Brazil } \\
\text { Cities, States (GPS) }\end{array}$ & DSL & FUEL \\
\hline \multirow[t]{5}{*}{10} & Matos Costa, Santa Catarina (W $51^{\circ} 07^{\prime} 52^{\prime \prime}-\mathrm{S} 26^{\circ} 27^{\prime} 68^{\prime \prime}$ ) & \multirow[t]{5}{*}{$20.96 \mu \mathrm{m}$} & C.R.M. Silva \& A.L.L. Vanzela 85a (ICN) \\
\hline & Viamão, Rio Grande do Sul (W $\left.50^{\circ} 44^{\prime} 33^{\prime \prime}-\mathrm{S} 30^{\circ} 06^{\prime} 18^{\prime \prime}\right)$ & & C.R.M. Silva \& A.L.L. Vanzela 184 (ICN) \\
\hline & Balneário Pinhal, Rio Grande do Sul (W $\left.50^{\circ} 12^{\prime} 52^{\prime \prime}-\mathrm{S} 30^{\circ} 12^{\prime} 08^{\prime \prime}\right)$ & & C.R.M. Silva \& A.L.L. Vanzela 216 (ICN) \\
\hline & 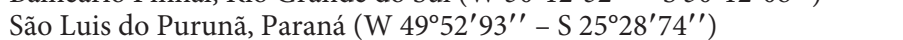 & & C.R.M. Silva \& A.L.L. Vanzela 100 (ICN) \\
\hline & Palmeira (BR 277), Paraná (W $50^{\circ} 09^{\prime} 49^{\prime \prime}-\mathrm{S} 25^{\circ} 24^{\prime} 49^{\prime \prime}$ ) & & C.R.M. Silva \& A.L.L. Vanzela 71 (ICN) \\
\hline 7 & Bom Sucesso de Itararé, São Paulo (W $\left.49^{\circ} 07^{\prime} 95^{\prime \prime}-\mathrm{S} 24^{\circ} 11^{\prime} 47^{\prime \prime}\right)$ & $20.30 \mu \mathrm{m}$ & Gaeta M.L. \& A.L.L. Vanzela 244 (ICN) \\
\hline \multirow[t]{4}{*}{6} & Curitiba, Paraná (W $\left.49^{\circ} 16^{\prime} 40^{\prime \prime}-S 25^{\circ} 23^{\prime} 04^{\prime \prime}\right)$ & \multirow[t]{4}{*}{$20.46 \mu \mathrm{m}$} & C.R.M. Silva 72 (ICN) \\
\hline & 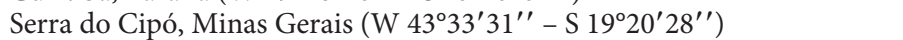 & & C.R.M. Silva \& A.L.L. Vanzela 142 (ICN) \\
\hline & Conceição do Mato Dentro, Minas Gerais (W $43^{\circ} 25^{\prime} 03^{\prime \prime}-\mathrm{S} 19^{\circ} 02^{\prime} 03^{\prime \prime}$ ) & & C.R.M. Silva \& A.L.L. Vanzela 139 (ICN) \\
\hline & Bom Sucesso de Itararé, São Paulo (W $\left.49^{\circ} 07^{\prime} 95^{\prime \prime}-\mathrm{S} 24^{\circ} 11^{\prime} 47^{\prime \prime}\right)$ & & Gaeta M.L. \& A.L.L. Vanzela 245 (ICN) \\
\hline
\end{tabular}

About 60 of the more than 200 species of Eleocharis are found in Brazil (Trevisan and Boldrini, 2008). Eleocharis maculosa (Vahl) Roem. \& Schult. occurs from Central America to the south of Brazil (Svenson, 1929; Trevisan and Boldrini, 2008). Chromosome counts in this species indicate the existence of four different chromosome numbers $(2 \mathrm{n}=10,8,7$ and 6$), 2 \mathrm{n}=10$ being initially described by da Silva et al. (2008). In order to understand this numeric variation, samples of 11 populations of E. maculosa were studied using different cytogenetic tools. The discussion shows how the findings lead to a better understanding of the evolutionary role of the symploidy in the process of karyotype differentiation in the formation of chromosome races in $E$. maculosa.

\section{Material and methods}

Representatives of Eleocharis maculosa were collected from eleven flooded regions in five Brazilian states (Table 1). Three to five samples of each population were cultivated in pots at the Laboratório de Biodiversidade e Restauração de Ecossistemas (LABRE) of the Universidade Estadual de Londrina (UEL) to produce new roots and anthers. Vouchers were deposited in the herbarium of the Universidade Federal do Rio Grande do Sul (ICN). For the study of somatic chromosomes, roots were pretreated with $2 \mathrm{mM} 8$-hydroxyquinoline for $24 \mathrm{~h}$ and fixed in absolute ethanol:glacial acetic acid (3:1,v:v) for $12 \mathrm{~h}$ and kept at $-20^{\circ} \mathrm{C}$ until used. Root tips were digested for $3 \mathrm{~h}$ in a mixture of $2 \%(\mathrm{w} / \mathrm{v})$ cellulase and $20 \%(\mathrm{v} / \mathrm{v})$ pectinase, further hydrolyzed in $1 \mathrm{~N} \mathrm{HCl}$ at $60^{\circ} \mathrm{C}$ for $11 \mathrm{~min}$, dissected in a drop of $45 \%$ acetic acid and squashed. The cover slips were removed after freezing in liquid nitrogen. The material was stained with $2 \%$ Giemsa and permanent slides mounted in Entellan. The size of the chromosomes and the length of the diploid set were measured from ten different metaphases of each population, considering each chromosome number.

For meiotic study, spikelets were dissected and the anthers immediately fixed in absolute ethanol:glacial acetic acid (3:1, v:v) for $12 \mathrm{~h}$, and kept at $-20^{\circ} \mathrm{C}$ until used. Anthers were hydrolyzed in $1 \mathrm{~N} \mathrm{HCl}$ at $60^{\circ} \mathrm{C}$ for $5 \mathrm{~min}$ and squashed in a drop of $45 \%$ acetic acid. The coverslips were removed after freezing, as described above, and the samples were stained with $2 \%$ Giemsa. Slides were mounted with Entellan.

Fluorescent in situ hybridization (FISH) was performed according to Heslop-Harrison et al. (1991) and Cuadrado and Jouve (1994), with modifications. Slides were prepared with root tips pretreated as described above. Root tips were softened in $2 \%$ cellulase plus $20 \%$ pectinase at $37^{\circ} \mathrm{C}$ for $3 \mathrm{~h}$ and squashed in a drop of $45 \%$ acetic acid, without acid hydrolysis. The $45 \mathrm{~S}$ rDNA probe from Triticum aestivum and the (TTTAGGG) ${ }_{n}$ telomeric probe from Arabidopsis thaliana (Richards and Ausubel, 1988) were labeled with biotin-14-dATP and the 5S rDNA probe from Rhynchospora pubera (Angeles Cuadrado, unpublished) was labeled with digoxigenin-11-dUTP, both by nick translation. The probes of rDNA were simultaneously utilized for FISH and the telomeric probe was separately hybridized. For FISH, a $34 \mu \mathrm{l}$ mixture was used composed of $100 \%$ formamide $(15 \mu \mathrm{l}), 50 \%$ polyethylene glycol $(6 \mu \mathrm{l}), 20 \times \mathrm{SSC}(3 \mu \mathrm{l}), 100 \mathrm{ng}$ of calf thymus DNA $(1 \mu \mathrm{l}), 10 \%$ SDS $(1 \mu \mathrm{l})$, and $200 \mathrm{ng}$ of probes $(4 \mu \mathrm{l}$ each). The material was denatured at $90^{\circ} \mathrm{C}$ for $10 \mathrm{~min}$ and hybridization was performed at $37^{\circ} \mathrm{C}$ overnight in a humidified chamber. Post-hybridization washes were carried out in $2 \times$ SSC, $20 \%$ formamide in $0.1 \times$ SSC, $0.1 \times$ SSC and $4 \times$ SSC $/ 0.2 \%$ Tween 20 , all at $42^{\circ} \mathrm{C}$. The probes were simultaneously detected with avidin-FITC conjugate and anti-dig-rhodamine conjugate. The postdetection washes were performed in $6 \times$ SSC and $4 \times$ SSC $/ 0.2 \%$ Tween 20 , all at room temperature. Slides were mounted with $25 \mu \mathrm{l}$ of antifade, composed of glycerol (90\%), 1,4-diaza-bicyclo(2,2,2)-octane (2.3\%), 20 $\mathrm{mM}$ TrisHCl, $\mathrm{pH} 8.0$ (2\%), $2.5 \mathrm{mM} \mathrm{MgCl}_{2}$ (4\%) and distilled water (1.7\%), plus $1 \mu \mathrm{l}$ of $2 \mu \mathrm{g} \mathrm{ml}^{-1} 4^{\prime}, 6$-diamidino-2-phenylindole (DAPI).

All the images were acquired separately without color (black and white) with a Leica DM 4500 B microscope equipped with a DFC 300FX camera and overlapped with blue colors for DAPI, green-yellowish for FITC and red for rhodamine, using the Leica IM50 4.0 software. The images were optimized for best contrast and brightness with iGrafx Image software.

\section{Results and discussion}

\section{Morphological analysis and conventional karyotype}

All individuals studied are part of a complex identified as Eleocharis maculosa s.l. (Svenson, 1929), belonging to the subgenus Eleocharis, section Maculosae (González-Elizondo and Peterson, 1997). Independent of the locality, individuals exhibited an apex of upper sheath membranous, rugose and hyaline without a mucron, spikelet ovoid to lanceolate, the scales ovate with scarious margins and reddish to brownish sides that become lighter at age; and obovoid, black achenes. The conventional study performed on 13 

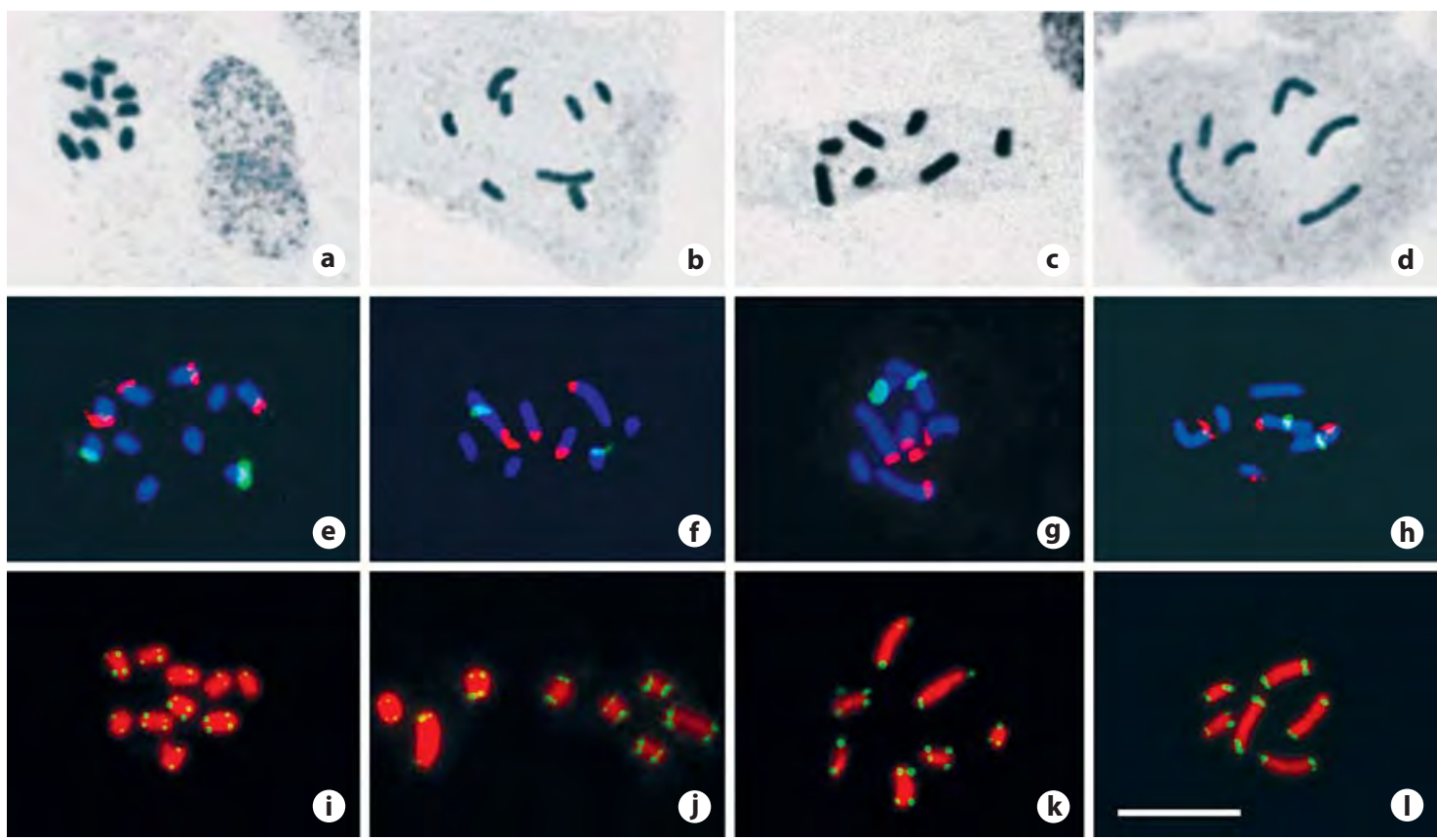

Fig. 1. Conventional staining and FISH with rDNA probes in Eleocharis maculosa. (a) Mitotic metaphase of plesiomorphic chromosome race with $2 \mathrm{n}=10$ (note the chromocentric interphase nuclei). (b-d) Metaphase and prometaphases in the chromosome races with $2 \mathrm{n}=8(\mathbf{b}), 2 \mathrm{n}=7$ (c) and $2 \mathrm{n}=6(\mathbf{d})$. (e-h) Double FISH with 45S rDNA (red) and $5 \mathrm{~S}$ rDNA (green) probes, where the chromosome races are $(\mathbf{e}) 2 \mathrm{n}=10$, (f) $2 \mathrm{n}=8,(\mathbf{g}) 2 \mathrm{n}=7$, and (h) $2 \mathrm{n}=6$. The chromosomes were counterstained with DAPI (blue). (i-I) FISH with (TTTAGGG) ${ }_{n}$ probe (yellowish green), where the chromosome races are (i) $2 \mathrm{n}=10,(\mathbf{j}) 2 \mathrm{n}=8,(\mathbf{k}) 2 \mathrm{n}=7$, and (I) $2 \mathrm{n}=6$. The chromosomes were counterstained with DAPI (red). Scale bar $=10 \mu \mathrm{m}$.

samples of 11 populations of $E$. maculosa showed four chromosome numbers: $2 \mathrm{n}=10,8,7$ and 6 (Fig. 1a-d). The number $2 \mathrm{n}=10$ was recorded by da Silva et al. (2008), the other ones are described here for the first time. Given that the samples studied exhibited similar morphological features that do not enable the recognition of infraspecific taxa, we believe that the different karyotypes represent 'chromosome races' of Eleocharis maculosa.

The number $2 \mathrm{n}=10$ was observed in six populations, $2 n=8$ in two, $2 n=7$ in one and $2 n=6$ in four. Most of the populations included individuals with just one chromosome number, except those of Palmeira, Paraná, with $2 \mathrm{n}=$ 10 and 8 and Bom Sucesso de Itararé, São Paulo, with $2 \mathrm{n}=$ 7 and 6 (Table 1). The karyotype with $2 \mathrm{n}=10$ was the most symmetrical, with chromosomes decreasing gradually in size, unlike $2 \mathrm{n}=8$ (two large and six smaller chromosomes), $2 \mathrm{n}=7$ (three large and four smaller) and $2 \mathrm{n}=6$ (four large and two smaller chromosomes) which were bimodals (Fig. 1a-d). In spite of differences found in the sizes of individual chromosomes among the samples, the values of diploid set sizes were similar in all the samples with $2 \mathrm{n}=10,8$, 7 and 6 (Table 1).

Species with more than one chromosome number are common in some genera of Cyperaceae, e.g., Carex blepharicarpa Franchet with $2 \mathrm{n}=26-32$ and 41 (Hoshino and Okamura, 1994), C. sociata Boott with $2 \mathrm{n}=40-44$ (Ohkawa et al., 2000); Rhynchospora nervosa (Vahl) Böckeler with
$2 \mathrm{n}=20$ and 30, R. globosa (H B K.) Roem. \& Schult., $2 \mathrm{n}=$ 24, 37 and 48 (Luceño et al., 1998); R. confinis (Nees) C. B. Clarke with $2 \mathrm{n}=10$ and 20 (Vanzela et al., 2000), Eleocharis palustris subsp. palustris (L.) Roem. et Schult., $2 \mathrm{n}=15$ and 16 and E. palustris subsp. vulgaris Walters, $2 \mathrm{n}=36,38,39$ and 42 (Strandhede, 1965), and Eleocharis kamtschatica (C. A. Mey.) Kom., 2n = 41-47 (Yano and Hoshino, 2006). Several of these studies point out that symploidy and agmatoploidy are responsible for the numeric variations. However, it has not been clearly shown which chromosomes are involved in these rearrangements. The plants studied here showed similar morphological features and size of diploid complement, and so the differences in the chromosome numbers could have originated by fusion of holocentric chromosomes, or symploidy, as proposed by Luceño and Guerra (1996). This event was responsible for the reduction in chromosome number in Rhynchospora tenuis Link from the probable basic number $\mathrm{x}=5$ (Vanzela et al., 1996).

\section{FISH and meiotic analysis}

The samples studied here showed the same number of rDNA hybridization signals, being always four signals of $45 \mathrm{~S}$ rDNA and two signals of $5 \mathrm{~S}$ rDNA. The karyotypes with $2 \mathrm{n}=10$ exhibited only terminal signals, while in the karyotypes with $2 \mathrm{n}=8,7$ and $6,45 \mathrm{~S}$ rDNA signals were always terminal (red color) and 5S rDNA signals were terminal and interstitial (green color) (Fig. 1e-h). Meiotic and FISH anal- 


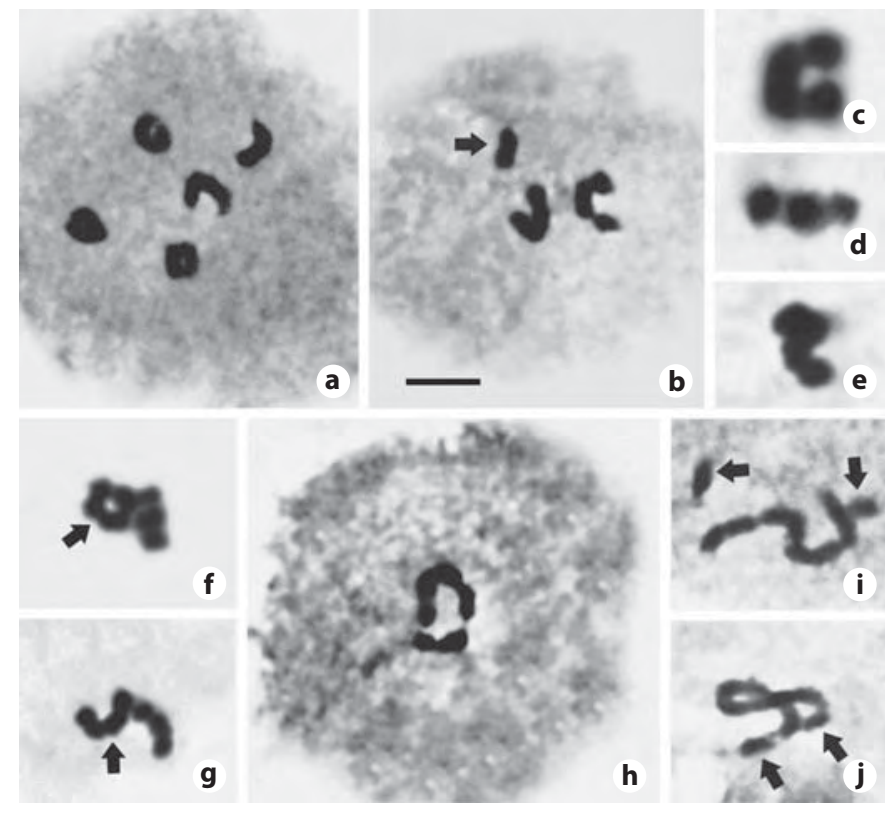

Fig. 2. Meiosis in Eleocharis maculosa. (a) Metaphase I with five bivalents in the chromosome race with $2 \mathrm{n}=10$. (b) Chromosome race with $2 \mathrm{n}=8$ showing one bivalent (arrow) and two heteromorphic trivalents in metaphase I. (c-e) Trivalents of chromosome race with $2 \mathrm{n}=$ 8 in a larger magnification. The smaller chromosomes on the same side of the larger (c), the smaller ones at both ends (d) and one small on each side of the larger chromosome (e). (f and $\mathbf{g})$ Chromosome race with $2 \mathrm{n}$ $=7$ showing one tetravalent (arrows) and one trivalent in chain. Arrows point out a ring tetravalent (f) and a chain tetravalent $(\mathbf{g})$. (h-j) Chromosome race with $2 \mathrm{n}=6$ showing one hexavalent structure $(\mathbf{h})$ and a linear hexavalent (i and $\mathbf{j}$ ). The arrows point out two small chromosomes located at the ends in (i) and (j). Scale bar $=5 \mu \mathrm{m}$.

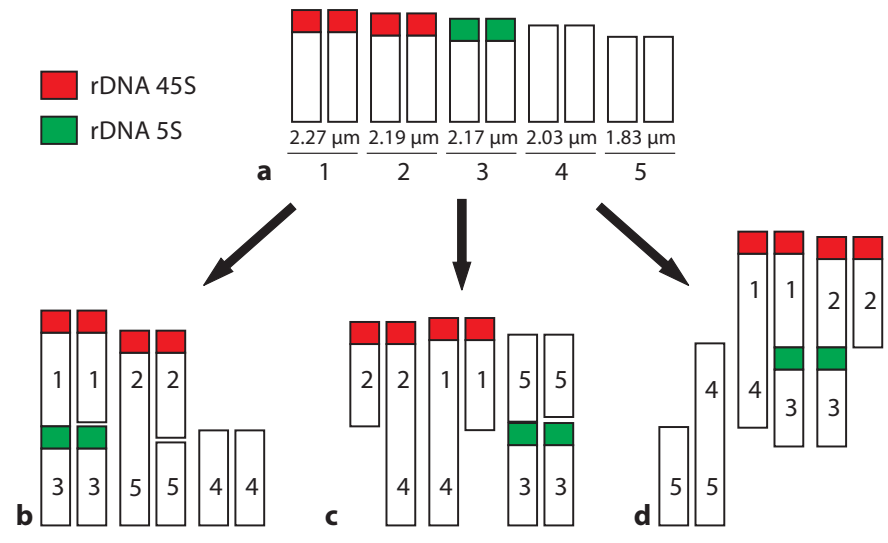

Fig. 3. Idiograms showing the symploidy pathways to formation of chromosome races in Eleocharis maculosa. The chromosome arrangement in the idiogram follows possible meiotic pairing. (a) Chromosome races with $2 \mathrm{n}=10$. The $\mu \mathrm{m}$ values correspond to the average of the size of each pair. (b-d) Chromosome race with $2 \mathrm{n}=8,7$ and 6 , respectively. yses allowed us to propose the pathways in which the chromosome reduction occurred from one plesiomorphic karyotype $(2 \mathrm{n}=10)$ with terminal hybridization sites to different karyotypes with interstitial and terminal sites of rDNA. Meiotic analysis performed in six samples with $2 \mathrm{n}=10$ showed for all cases the presence of five bivalents at metaphase I (Fig. 2a), comprising a regular meiosis typical of a plesiomorphic karyotype in the context of Eleocharis maculosa. However, the samples with reduced chromosome numbers displayed different configurations in the first phase of meiosis.

The chromosome race with $2 n=8$ : In the two samples with $2 \mathrm{n}=8$, the formation of one bivalent was observed, composed probably of two smaller chromosomes, and two different heteromorphic trivalents, each one composed of a larger chromosome pairing with two smaller chromosomes (Fig. 2b). The trivalents appeared arranged in at least three different forms: (i) the largest chromosome with two smaller on the same side (Fig. 2c), (ii) linear with the smaller ones at both tips (Fig. 2d), and (iii) a small chromosome on each side of the larger one (Fig. 2e). FISH with rDNA probes revealed that one of the largest chromosomes had two hybridization signals. One of these was terminal (45S rDNA) and the other was interstitial (5S rDNA). According to our chromosome measurements, the largest chromosome can be the result of the fusion of a homolog of pair 1 with a homolog of pair 3 (see Fig. 3). Due to this association, these heterologous chromosomes appear as a heteromorphic trivalent at meiosis (see Fig. 2b). The second largest chromosome showed only one terminal signal with the $45 \mathrm{~S}$ rDNA probe. This might have been the result of the fusion of a homolog of pair 2 probably with a homolog of pair 5 , which is suggested also by the chromosome measurements (see Fig. 3). In this case, this association appears also as a heteromorphic trivalent at meiosis (see Fig. 2b). Three other chromosomes with similar sizes exhibited terminal signals, two with the $45 \mathrm{~S}$ rDNA and one with the $5 \mathrm{~S}$ rDNA probe. The other three smallest do not show hybridization signals (Figs. 1f, 3). Finally, the only bivalent may be formed by two chromosomes of pair 4 (Fig. 3).

The chromosome race with $2 n=7$ : FISH analysis of mitotic chromosomes with rDNA probes showed that the three largest chromosomes exhibited only one hybridization signal each. Two chromosomes showed terminal signals with the $45 \mathrm{~S}$ rDNA probe and the other chromosome showed one interstitial signal with the $5 \mathrm{~S}$ rDNA probe. Three of the four other smaller chromosomes displayed a terminal signal, where two were hybridized by the $45 \mathrm{~S}$ rDNA probe and one by the $5 \mathrm{~S}$ rDNA probe (Fig. 1g). According to our chromosome measurements, the largest chromosome is the result of the fusion of a homolog of pair 1 with a homolog of pair 4. The second largest chromosome may be the result of the fusion of a homolog of pair 2 probably with a homolog of pair 4. Similarly, the third largest chromosome can be the result of the fusion of a homolog of pair 3 with probably a homolog of pair 5 . The remaining smaller chromosomes, exhibited terminal signals, two with $45 \mathrm{~S}$ rDNA and one with $5 \mathrm{~S}$ rDNA, except for one without signals (Fig. 3c). Mei- 
otic analysis done on this chromosome race always showed one tetravalent and one trivalent, both heteromorphic. The tetravalent appears forming a ring structure or in a chain, and the trivalent always appears in a chain (Fig. 2f, g). The tetravalent configuration can be a result of the pairing among fused chromosomes $1 / 4$ and 2/4, besides the homologous chromosomes 1 and 2, which are not fused. The trivalent was composed of fused chromosome $3 / 5$ associated with its non-fused homologs, as suggested also by chromosome measurements (Fig. 3). However, we cannot reject the possibility of translocations, because ring structures were found, as observed in E. subarticulata (da Silva et al., 2005).

The chromosome race with $2 n=6$ : Meiotic analysis of the samples with $2 \mathrm{n}=6$ showed that all chromosomes appeared as a single multivalent structure. In most cases the chromosomes formed a hexavalent structure, but not in a ring form (Fig. 2h-j). Da Silva et al. (2005) observed one hexavalent ring in Eleocharis subarticulata, however, it originated by multiple translocations. In the chromosome race with $2 \mathrm{n}=$ 6 we found a multivalent association with two chromosomes of small size located at the extremes, but not physically associated with each other (Fig. 2i, j). FISH with rDNA probes showed that in mitotic metaphases the first and second largest chromosomes, which differed in size, each exhibited two hybridization signals.

These were terminal with the $45 \mathrm{~S}$ rDNA probe and interstitial with the $5 \mathrm{~S}$ rDNA probe (Fig. 1h). According to our analysis, the two homologs of pair 3 , containing the $5 \mathrm{~S}$ rDNA sites, were fused with two different heterologous chromosomes, one of pair 1 and the other of pair 2 and both containing $45 \mathrm{~S}$ rDNA sites (Figs. $1 \mathrm{~h}, 3 \mathrm{~d}$ ). Continuing the reasoning for the explanation of the formation of the hexavalent structure, the two homologs of pair 4, without rDNA sites, were also fused with two different heterologous chromosomes, one from pair 1 (containing $45 \mathrm{~S}$ rDNA site) and the other from pair 5 without rDNA sites (Fig. 3d). Thus, the two small chromosomes located at the ends of the hexavalent structure may correspond to the chromosomes of pairs 2 and 5 that were not fused (Fig. 3d).

The use of conventional and molecular techniques allows us to identify most of the chromosomes that participated in the fusion processes, as well as the different combinations of the chromosomes giving rise to each reduced karyotype. This combination of different procedures has been useful in identifying chromosomes in other plant groups that exhibit rearrangements, e.g., Arabidopsis (Lysak et al., 2006) and Brachyscome (Adachi et al., 1997). FISH with (TTTAGGG) probes was used here to verify if there was the maintenance of ectopic segments after process of chromosome reduction in E. maculosa. The absence of ectopic signals in the samples with $2 \mathrm{n}=10,8,7$ and 6 (Fig. 1i-l) could indicate that the chromosome races appeared from translocations with terminal breakpoints and subsequent loss of small products (with telomeres), as found in Arabidopsis (Lysak et al., 2006). However, breaks in chromosomes with diffuse kinetochores could originate mini or micro-chromosomes with kinetic activity and be viable in cell division (see Håkanson, 1954 and Vanzela and Colaço, 2002). But, these little chromosomes were not found in our study. We suggested that the fusion process happened due to symploidy of holocentrics, as described in Rhynchospora tenuis with $2 \mathrm{n}=4$ and 8 (Vanzela et al., 2003).

Interstitial telomeric sites have been shown in Haplopappus gracilis with $2 \mathrm{n}=4$ (Hanmoto et al., 2007) and in Eleocharis subarticulata with $2 \mathrm{n}=6$ (da Silva et al., 2005) due to chromosome fusion and multiple translocation processes, respectively. According to Schubert (2007) telomeric sequences may occupy interstitial positions because of translocation or inversion, and can be considered to be hot spots of chromosome breakage. Chromosome fusions without the maintenance of telomeric ectopic sites have also taken place in other plant groups with monocentric chromosomes (Cox et al., 1993; Fuchs et al., 1995). The 'minimum-interaction hypothesis' of Imai et al. (1986), elaborated in monocentric systems, states that karyotype evolution has been in large part shaped by selection to reduce the occurrence of such fitness-reducing spontaneous chromosomal mutations as reciprocal translocations. Thus, we suggested symploidy as the principal chromosome reduction mechanism in E. maculosa. However, we cannot discard the translocation in the chromosome races formation, since a ring configuration was found in meiosis of the race with $2 n=7$.

Jones (1998) mentions that most of the suspected cases of chromosome fusion and fission are records of karyotype comparisons of small numbers of individuals. Most of the records involve groups with monocentric chromosomes, whose karyotype evolution tends to increase chromosome numbers, mainly by polyploidy, where reduction in chromosome number is rarely considered (Schubert, 2007). In the context of holocentric chromosomes, the pathways of karyotype evolution also seem to be associated with increased chromosome numbers, due to agmatoploidy and polyploidy. In Carex, the most studied genus of Cyperaceae, a decrease in chromosome number is not common (Hipp et al., 2008). Thus, considering that most of the chromosome numbers recorded for Eleocharis are equal to or larger than $2 \mathrm{n}=10$, with $\mathrm{x}=5$ as the probable basic number, the chromosome races found in E. maculosa can be an apomorphic feature. In conclusion, our findings reinforce the suggestion of Guerra (2008) that descending disploidy, reaching very small chromosome numbers, is more frequent in organisms with holokinetic chromosomes.

\section{Acknowledgements}

We are very grateful to Dr. Rafael Trevisan for sample identification and herbarium work and to Dr. A. Leyva for English correction and editing. 


\section{References}

Adachi J, Watanabe K, Fukui K, Ohmido, N, Kosuge $\mathrm{K}$ : Chromosomal location and reorganization of the $45 \mathrm{~S}$ and $5 \mathrm{~S}$ rDNA in the Brachyscome $l i$ neariloba complex (Asteraceae). J Plant Res 110: 371-377 (1997).

Chiarini F, Bernardello G: Karyotype studies in South American species of Solanum subgen. Leptostemonum (Solanaceae). Plant Biol 8:486493 (2006).

Cox AV, Bennett ST, Parokonny AS, Kenton A, Callimassia MA, Bennett MD: Comparison of a plant telomere location using a PCR-generated synthetic probe. Ann Bot 72:239-247 (1993).

Cuadrado A, Jouve N: Mapping and organization of highly-repeated DNA sequences by means of simultaneous and sequential FISH and C-banding in $5 x$-Triticale. Chromosome Res 2:231-338 (1994).

da Silva CRM, González-Elizondo MS, Vanzela ALL: Reduction of chromosome number in Eleocharis subarticulata (Cyperaceae) by multiple translocations. Bot J Linn Soc 149:457-464 (2005).

da Silva CRM, González-Elizondo MS, Rego LNAA, Torezan JMD, Vanzela ALL: Cytogenetical and cytotaxonomical analysis of some Brazilian species of Eleocharis (Cyperaceae). Aust J Bot 56:82-90 (2008).

Fuchs J, Brandes A, Schubert I: Telomere sequence localization and karyotype evolution in higher plants. Pl Syst Evol 196:227-241 (1995).

González-Elizondo MS, Peterson PM: A classification of and key to the supraspecific taxa in Eleocharis (Cyperaceae). Taxon 46:433-449 (1997).

Guerra M: Chromosome numbers in plant cytotaxonomy: concepts and implications. Cytogenet Genome Res 120:339-350 (2008).

Håkanson A: Meiosis and pollen mitosis in X-rayed and untreated spikelets of Eleocharis palustris. Hereditas 40:325-345 (1954).
Hanmoto H, Kataoka R, Ohmido N, Yoshihiko Y: Interstitial telomere-like repeats in the Haplopappus gracilis (Asteraceae) genome revealed by fluorescence in situ hybridization. Cytologia 72:483-488 (2007).

Heslop-Harrison JS, Schwarzacher T, Anamthawat-Jonsson K, Leitch AR, Shi M, Leitch IJ: In situ hybridization with automated chromosome denaturation. Technique 3:106-109 (1991).

Hipp AL, Rothrock PE, Roalson EH: The evolution of chromosome arrangements in Carex (Cyperaceae). Bot Rev, in press (2008).

Hoshino T, Okamura K: Cytological studies on meiotic configurations of intraspecific aneuploids of Carex blepharicarpa (Cyperaceae) in Japan. J Plant Res 107:1-8 (1994).

Ikeda $\mathrm{H}$ : Cytogenetic studies on the chromosome complements of Haplopappus gracilis $(2 \mathrm{n}=4)$ and $H$. ravenii $(2 \mathrm{n}=8)$. J Sci Hiroshima Univ B 2:67-104 (1987).

Imai HT, Maruyama T, Gojobori T, Inoue Y, Crozier $\mathrm{RH}$ : Theoretical bases for karyotype evolution. 1. The minimum-interaction hypothesis. Am Nat 128:900-920 (1986).

Jones K: Robertsonian fusion and centric fission in karyotype evolution of higher plants. Bot Rev 64:273-289 (1998).

Luceño M, Guerra M: Numerical variation in species exhibiting holocentric chromosomes: a nomenclatural proposal. Caryologia 49:301-309 (1996).

Luceño M, Vanzela ALL, Guerra M: Cytotaxonomic studies in Brazilian Rhynchospora (Cyperaceae), a genus exhibiting holocentric chromosomes. Can J Bot 76:440-449 (1998).

Lysak MA, Berr A, Pecinka A, Schmidt R, McBreen K, Schubert I: Mechanisms of chromosome number reduction in Arabidopsis thaliana and related Brassicaceae species. Proc Natl Acad Sci USA 13:5224-5229 (2006).

Ohkawa T, Yokota M, Hoshino T: Aneuploidal population differentiation in Carex sociata Boott (Cyperaceae) of the Ryukyu Islands, Japan. Bot J Linn Soc 132:337-358 (2000).
Rath SP, Patnaik SN: Cytological studies in Indian species of Fimbristylis Vahl. (Cyperaceae) with special reference to taxonomy, in Manna GK, Sinha U (eds): Perspectives in Cytology and Genetics 3:175-181 (Hindasia Publishers, New Delhi 1981).

Richards EJ, Ausubel FM: Isolation of a higher eukaryotic telomere from Arabidopsis thaliana. Cell 53:127-136 (1988).

Ruas PM, Vanzela ALL, Vieira AOS, Bernini C, Ruas CF: Karyotype studies in Brazilian species of Lobelia L., subgenus Tupa (Campanulaceae). Revta Brasil Bot 24:249-254 (2001).

Schubert I: Chromosome evolution. Curr Opin Plant Biol 10:109-115 (2007).

Strandhede SO: Chromosome studies in Eleocharis, subser. Palustres. Opera Bot 9:1-86 (1965).

Svenson HK: Contributions from the Gray Herbarium of Harvard University. LXXXVI. Monographic studies in the genus Eleocharis. Rhodora 31:121-245 (1929).

Trevisan R, Boldrini II: O gênero Eleocharis R. Br. (Cyperaceae) no Rio Grande do Sul, Brasil. Rev Bras Biociênc 1:7-67 (2008).

Vanzela ALL, Colaço W: Mitotic and meiotic behavior of y irradiated holocentric chromosomes of Rhynchospora pubera (Cyperaceae). Acta Scient 24:611-614 (2002).

Vanzela ALL, Guerra M, Luceño M: Rhynchospora tenuis Link (Cyperaceae), a species with the lowest number of holocentric chromosomes $(\mathrm{n}=2)$. Cytobios 88:219-228 (1996).

Vanzela ALL, Luceño M, Guerra M: Karyotype evolution and cytotaxonomy in Brazilian species of Rhynchospora Vahl (Cyperaceae). Bot J Linn Soc 134:557- 566 (2000).

Vanzela ALL, Cuadrado A, Guerra M: Localization of $45 \mathrm{~S}$ rDNA and telomeric sites on holocentric chromosomes of Rhynchospora tenuis Link (Cyperaceae). Gen Mol Biol 26:199-201 (2003).

Yano O, Hoshino T: Cytological studies of aneuploidy in Eleocharis kamtschatica (Cyperaceae). Cytologia 71:141-147 (2006). 


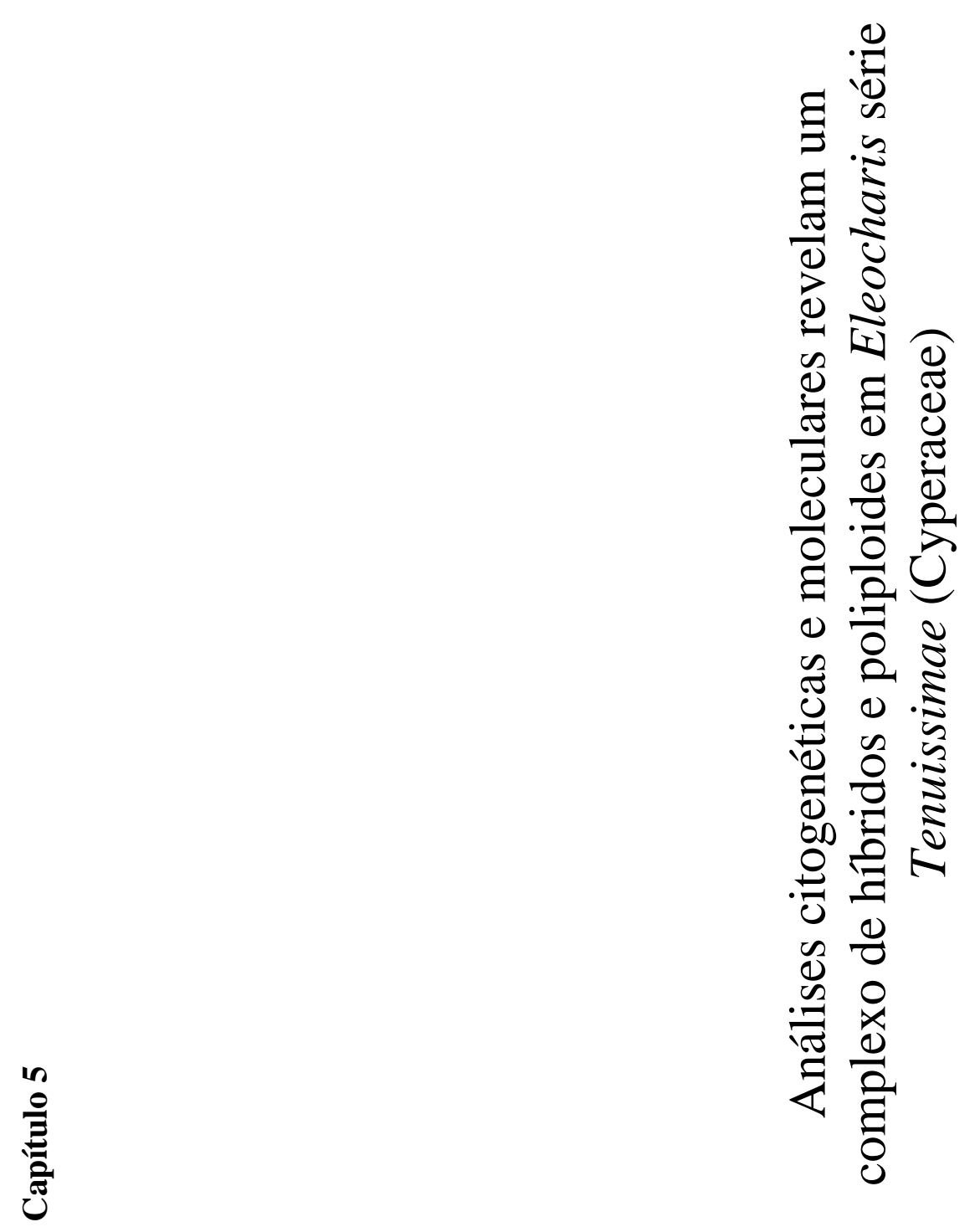


1 Análises citogenéticas e moleculares revelam um complexo de híbridos e 2 poliploides em Eleocharis série Tenuissimae (Cyperaceae)

3 Carlos Roberto Maximiano da Silva², Rafael Trevisan², Maria Socorro González4 Elizondo $^{3}$, Elson Felipe Sandoli Rosseto ${ }^{4}$, Carolina Cristina Quintas ${ }^{5}$, Rogério 5 Fernandes de Souza ${ }^{5}$, André Luís Laforga Vanzela ${ }^{5,6}$

$7 \quad{ }^{1}$ Instituto de Biociências, Letras e Ciências Exatas, UNESP, 15054-000, São José do 8 Rio Preto, SP, Brazil.

$9 \quad{ }^{2}$ Universidade Federal do Rio Grande do Sul, 91501-970, Porto Alegre, RS, Brazil.

$10{ }^{3}$ CIIDIR IPN Unidad Durango, Sigma s.n. Fracc. 20 de Noviembre II, 34220 Durango, 11 Dgo., Mexico.

$12{ }^{4}$ Departamento de Biologia Vegetal e Animal, CCB, Universidade Estadual de 13 Londrina, 86051-970, Londrina, PR, Brazil.

14 5aboratório de Biodiversidade e Restauração de Ecossistemas, Departamento de 15 Biologia Geral, CCB,

$16 \quad{ }^{7}$ Corresponding author. Email: andrevanzela@uel.br

Resumo

19 O gênero Eleocharis R. Br. possui características morfológicas bastante simples, 20 quando comparado com as demais Cyperaceae. Isto tem ocasionado problemas de 21 identificação e classificação, os quais não têm sido resolvidos com o auxílio de 22 ferramentas moleculares. Um dos grupos mais complexos do gênero é a série 23 Tenuissimae (C. B. Clarke) Svenson, de origem parafilética. Esta série exibe a maior 24 diversidade morfológica no gênero, incluindo complexos de espécies intimamente 25 relacionadas, como o complexo formado por Eleocharis viridans e E. niederleinii. Para 26 compreender a organização e evolução deste complexo, foram estudadas 39 amostras 27 coletadas em diversas regiões do Brasil. As análises revelaram uma série cromossômica 28 para ambas as espécies, as quais exibiram $2 n=20,29,30,31,35,40,41$ e 42. Em 29 alguns cariótipos foram encontrados de um a quatro cromossomos maiores, contendo ou 
1 não sítios de DNAr 45S. As poucas amostras que produziram flores férteis apresentaram 2 meiose regular, apenas com bivalentes. Os dados moleculares indicam que as 3 populações podem estar isoladas e a GISH revelou que duas destas populações têm 4 origem híbrida. Esses híbridos possuem reprodução exclusivamente vegetativa, o que 5 indica a ocorrência de isolamento ativo.

6

7

8 Palavras-chave: Alopoliploidia, DNAr 45S, Eleocharis, GISH, hibridação. 


\section{Introdução}

2 O gênero Eleocharis R. Br. possui características morfológicas bastante

3 reduzidas, quando comparado com as demais Cyperaceae (Trevisan e Boldrini 2008),

4 associadas a uma grande variação morfológica intraespecífica (Simpson 1988). Isto tem

5 ocasionado problemas de identificação e classificação, os quais vêm se mantendo

6 mesmo com o auxílio de ferramentas moleculares (Roalson e Friar 2000, Yano et al.

72004 e Roalson et al. in press). González-Elizondo e Peterson (1997) dividiram o

8 gênero Eleocharis em quatro subgêneros, seis seções, oito séries e sete subséries. Dentre

9 estes, encontra-se a série Tenuissimae (C. B. Clarke) Svenson, de origem para e

10 polifilética (Roalson e Friar 2000). Esta série exibe a maior diversidade morfológica e

11 distribuição no gênero, incluindo complexos de espécies intimamente relacionadas,

12 especialmente na América do Sul, indicando especiação ativa (González-Elizondo e

13 Tena-Flores 2000).

14 Estudos citogenéticos em Eleocharis, assim como nos outros representantes de

15 Cyperaceae, mostram que há uma grande variação cromossômica numérica, desde $2 n=$

166 em E. subarticulata (Da Silva et al. 2005) a $2 n=200$ em E. dulcis (Roalson 2008).

17 Esta variação está associada à condição holocêntrica dos cromossomos, devido a 18 eventos de agmatoploidia, simploidia, translocações e poliploidia (Luceño et al. 1998,

19 Da Silva et al. 2005, 2008a, Hipp et al. 2009). Há evidências de que em algumas

20 espécies, esses eventos podem levar a algum tipo de isolamento, como em

21 Rhynchospora tenuis, já que intermediários entre as raças cromossômicas simpátricas

$22 \operatorname{com} 2 n=4$ e 8 nunca foram encontrados (Vanzela et al. 1996). Similarmente, para $E$.

23 maculosa foram encontradas populações com $2 n=10$, 8, 7 e 6 (Da Silva et al. 2008b),

24 cujos cariótipos surgiram a partir de $2 n=10$, sem indícios de cruzamentos entre essas

25 raças cromossômicas. 
1 Estudos prévios realizados em representantes de E. viridans Boeck e E.

2 niederleinii Kük. Ex Osten da série Tenuissimae, revelaram diferentes números

3 cromossômicos e organização cariotípica, além de uma clara sobreposição de caracteres

4 diagnósticos. De acordo com Svenson (1939), Eleocharis viridans e E. niederleinii

5 podem ser sinonímias, contudo, diferentes taxonomistas consideram E. viridans como

6 uma espécie bem circunscrita. Essas espécies apresentam colmos quadrangulares,

7 variando de 0,2 -1,1 $\mu \mathrm{m}$ de largura, comportamento prolífero e raras vezes formam

8 espiguetas viáveis, levando a uma escassez de caracteres diagnósticos e erros na

9 identificação. Este problema pode ser bem exemplificado em Rambo (1959) na

10 separação entre E. viridans e E. filiculmis, em Trevisan e Boldrini (2008) entre E.

11 viridans e E. dunensis, bem como na determinação errônea de E. niederleinii registrada

12 em vários herbários brasileiros (Alves et al. 2010). Para entender a relação entre

13 Eleocharis viridans e E. niederleinii, neste estudo foram empregadas ferramentas

14 citogenéticas, como coloração convencional, para análises meióticas e mitóticas, FISH

15 com sonda de DNAr 45S e GISH e moleculares como, o RAPD, em 39 amostras dessas

16 duas entidades taxonômicas, coletadas em 18 localidades das regiões Sul e Sudeste do

17 Brasil.

18

19 Materiais e Métodos

As análises morfológicas dividiram as 39 amostras coletadas, em duas espécies,

2219 foram determinadas como E. niederleinii e 20 como E. viridans (Tabela 1). Estas

23 amostras foram mantidas em casa de vegetação do LABRE (Laboratório de

24 Biodiversidade e Restauração de Ecossistemas), do Centro de Ciências Biológicas da 
1 Universidade Estadual de Londrina. As exsicatas foram depositadas no herbário da

2 Universidade Federal do Rio Grande Sul (ICN).

3

4 Citogenética convencional

Pontas de raízes foram pré-tratadas com 2 mM 8-hidroxiquinoleína por 24 h e

6 fixadas em etanol absoluto:ácido acético glacial (3:1, v:v) por $12 \mathrm{~h}$ e mantidas a $-20{ }^{\circ} \mathrm{C}$

7 até o uso. As pontas das raízes foram digeridas por $3 \mathrm{~h}$ a $37^{\circ} \mathrm{C}$ em uma mistura de $4 \%$

8 celulase e $40 \%$ pectinase (w:v), posteriormente hidrolisadas em $\mathrm{HCl} 1 \mathrm{~N}$ a $60{ }^{\circ} \mathrm{C}$ por 10

9 min e lavadas com água destilada. As amostras foram dissecadas e esmagadas em uma

10 gota de ácido acético a 60\% e coradas com Giemsa 2\%. O tamanho dos cromossomos e

11 o comprimento total do cariótipo foram medidos em dez diferentes metáfases de cada

12 população com o programa MicroMeasure 3.3.

13 Para o estudo das meioses, anteras foram fixadas em etanol absoluto:ácido

14 acético glacial (3:1, v:v), por $12 \mathrm{~h}$, e mantidas a $-20^{\circ} \mathrm{C}$ até o uso. As anteras foram

15 hidrolisadas em $\mathrm{HCl} 1 \mathrm{~N}$ a $60{ }^{\circ} \mathrm{C}$, por 9 min, e lavadas em água destilada.

16 Posteriormente, as amostras foram dissecadas em uma gota de ácido acético a $60 \%$ e

17 coradas com Giemsa 2\%.

18

Análises cito-moleculares

A hibridação in situ fluorescente (FISH) foi feita de acordo com Heslop-

21 Harrison et al. (1991), com modificações. A sonda de DNAr 45S obtida de Triticum

22 aestivum (pTa71) foi marcada com biotina-14-dATP por nick translation. Entre 100 e

23200 ng $(4 \mu \mathrm{L})$ da sonda foi adicionada a uma solução composta por formamida $100 \%$

$24(15 \mu \mathrm{L})$, polietilenoglicol 50\% (6 $\mu \mathrm{L}), 20 \times$ SSC (3 $\mu \mathrm{L}), 100$ ng de DNA de timo de

25 bezerro $(1 \mu \mathrm{L})$, SDS $10 \%(1 \mu \mathrm{L})$ e $\mathrm{H}_{2} \mathrm{O}(4 \mu \mathrm{L})$. A sonda foi desnaturada a $70{ }^{\circ} \mathrm{C}$ por 10 
1 min e a hibridação feita a $37^{\circ} \mathrm{C}$ por até 24 h. Os banhos pós-hibridação foram feitos

2 com $6 \times$ SSC e 4 SSC/0,2\% Tween 20, à temperatura ambiente. A sonda foi detectada

3 com avidina-FITC e os banhos pós detecção foram com 4× SSC/0,2\% Tween 20 a

4 temperatura ambiente. Os cromossomos foram contra-corados com DAPI e as lâminas

5 foram montadas com $25 \mu \mathrm{L}$ de antifade, composto por glicerol (90\%), 1,4-diaza-

6 bicyclo(2,2,2)-octane (2.3\%), 20 mM TrisHCl, pH 8.0 (2\%) e água destilada.

7 Para a hibridação genômica in situ (GISH) foi utilizado o mesmo protocolo da

8 FISH, exceto pelas sondas utilizadas na hibridação, as quais foram obtidas do DNA

9 genômico extraído das amostras com $2 n=20$ de E. viridans (amostra 186) e $E$.

10 niederleinii (amostra 44). Amostras de DNA genômico das duas espécies foram

11 fragmentadas por choque de temperatura, avaliadas em gel de eletroforese a $1 \%$ e em

12 seguida marcadas com biotina-14-dATP por nick translation. As hibridações in situ

13 foram feitas baseadas nos resultados das análises de RAPD e do coeficiente de

14 similaridade entre os genomas de cada amostra.

15 Todas as imagens, convencionais, FISH e GISH, foram capturadas em tons de

16 cinza em um fotomicroscópio Leica DM 4500 B equipado com câmera DFC 300FX. As

17 sobreposições e colorações das imagens foram feitas no programa IM50 da Leica e o

18 controle de brilho e contraste feito com o programa IGrafix.

Extração de DNA

O DNA genômico de 39 indivíduos das duas espécies foram extraídos de acordo

22 com o método CTAB (Brasileiro e Carneiro 1998), onde cerca de 3 a 4 colmos jovens

23 foram transferidos para um almofariz contendo nitrogênio líquido e macerados até a

24 obtenção de um pó fino. Cerca de $2 \mathrm{~mL}$ de tampão CTAB (Tris- $\mathrm{HCl} 1 \mathrm{M}$ pH 8, $\mathrm{NaCl}$

25 5M, EDTA 0,5M pH 8, CTAB, ßmercaptoetanol e PVP 40) foi adicionado ao pó e a 
1 solução foi transferida para um microtubo. A solução foi incubada em banho-maria a 65

$2{ }^{\circ} \mathrm{C}$, por $50 \mathrm{~min}$, tratada com Proteinase $\mathrm{K}(100 \mathrm{mg} / \mathrm{mL})$ a $65^{\circ} \mathrm{C}$, por mais $30 \mathrm{~min}$. Após

3 este período foi adicionado o mesmo volume de fenol:clorofórmio (1:1; v:v) e a solução

4 foi centrifugada a 10.000 rpm, por 10 min. Após a centrifugação, a fase superior foi

5 transferida para outro tubo e tratada com RNAse $(100 \mathrm{mg} / \mathrm{mL})$ a $37^{\circ} \mathrm{C}$ por $30 \mathrm{~min}$.

6 Após este período duas lavagens com clorofórmio:álcool isoamílico (24:1; v:v) foram

7 realizadas. A fase superior foi transferida para outro tubo e a ela foi adicionado 2,5

8 volumes de etanol absoluto para formar um precipitado. Este foi dissolvido em 50-100

$9 \mu \mathrm{L}$ de água destilada. As amostras foram quantificadas em um fluorômetro DyNA

10 Quant200 (Hoefer-Pharmacia).

Reação de RAPD

As reações de RAPD foram realizadas em apenas 39 amostras. Para estas

14 reações, foram testados 36 primers, dos quais oito do kit OPA (Operon Technologies -

15 Alameda, CA) foram selecionados. A reação de amplificação foi feita em um total de 15

$16 \mu \mathrm{L}$, contendo $1 \mathrm{mM}$ dNTP, 0,2 $\mathrm{mM}$ de primer, 2,5 $\mathrm{mM}$ de $\mathrm{MgCl}_{2}$ e uma unidade de

17 enzima (DNA polimerase), $1 \times$ o Tampão de reação e 15 a 25 ng de DNA e $\mathrm{H}_{2} \mathrm{O}$ Qsp.

18 As amplificações foram feitas em um termociclador MJ Research PTC-100 com a

19 seguinte programação: $92{ }^{\circ} \mathrm{C}$, por 4 min, seguido por 40 ciclos, sendo que cada ciclo

20 consiste em $40 \mathrm{seg}$, a $92^{\circ} \mathrm{C}, 1 \mathrm{~min}$ e $30 \mathrm{seg}$, a $40^{\circ} \mathrm{C}$ e 2 min a $72{ }^{\circ} \mathrm{C}$, e uma extensão

21 final de 5 min, a $72{ }^{\circ} \mathrm{C}$ após o último ciclo. Ao término da reação de amplificação, foi

22 adicionado $4 \mu \mathrm{L}$ de tampão da amostra (glicerol e azul de bromofenol) e a solução

23 aplicada em um gel de agarose 1,4\%, submerso em tampão de corrida TEB 0,5× (Tris

24 0,045 M, EDTA 0,5 mM e Ácido Bórico 0,045 M, pH 8,3). A eletroforese aconteceu a 3 
$1 \mathrm{~W} / \mathrm{cm}$, o gel foi corado com brometo de etídio por 5 minutos, exposto em

2 transiluminador ultravioleta e a imagem capturada com o programa Alpha Digi Doc RT.

3 Os perfis de RAPD foram determinados por comparação das bandas produzidas

4 para cada amostra em cada um dos oito primers e os dados comparados na forma de

5 variáveis binárias (1 presença e 0 ausência). Para as análises de similaridade genética

6 entre os indivíduos dos diferentes pontos foi utilizado o programa NTSYS-PC. Para a

7 construção do dendograma de similaridade genética foram empregados o coeficiente de

8 Jaccard (J) e o método de agrupamento UPGMA (Unwreighted Pair-Group Method

9 with Aritimetal Average). O programa STRUCTURE 2.2 (Pritchard et al. 2000; Falush

10 et al. 2003) foi empregado para determinar, por análise Bayesiana de agrupamento, o

11 número de entidades (K) geneticamente distintas. Neste caso, foi utilizada a

12 configuração para marcadores dominantes, conforme estabelecido por Falush et al.

13 (2007). Para ambas as espécies, as simulações foram realizadas com 100.000 repetições

14 pelo método Monte Carlo para a Cadeia de Markov (MCMC), após um período de

15 burning de 20.000 repetições. Essas simulações foram baseadas no modelo de mistura,

16 usando a opção de frequências alélicas correlacionadas, sem determinar a priori a

17 origem dos indivíduos. Duas metodologias foram empregadas para a escolha do número

18 mais provável de populações inferidas a partir do programa STRUCTURE 2.2. Os

19 resultados foram utilizados para direcionar as reações de hibridação genômica in situ.

21 Resultados

22 Todas as 39 amostras exibiram proliferação, ou seja, na extremidade do colmo, 23 novos colmos foram produzidos. Contudo, 22 delas também produziram espiguetas. As 24 amostras foram classificadas em duas espécies, sendo E. niederleinii aquelas que 25 apresentaram colmos de 0,2-0,4 mm de largura, bainha com 1,1-3,5 cm de 
1 comprimento, ápice oblíquo e bordo inconspícuo ou com pontos vináceos. Destas, oito

2 produziram espiguetas, que tiveram 3-9 × 1-2 mm de tamanho, forma lanceolada com

3 cor castanha, 10-18 flores; gluma inferior estéril, e glumas superiores frágeis e não

4 imbricadas (Tabela 1). Foram consideradas E. viridans as amostras mais robustas com

5 colmos de 0,3-1mm de largura, bainha com 1,5-8 cm de comprimento e ápice oblíquo.

6 Das 20 amostras consideradas E. viridans, sete produziram espiguetas (Tabela 1), que

7 tiveram 6-13 × 2-3 mm de tamanho, com forma ovóide e cor castanha a vinácea, com

8 30-60 flores; gluma inferior estéril, e glumas superiores imbricadas. Estas duas

9 entidades apresentaram como características sobrepostas a ausência de apêndice

10 hialino/rugoso e múcron dorsal.

11 As análises citogenéticas mostraram uma grande variação no número

12 cromossômico de ambas as espécies. As 19 amostras de E. niederleinii exibiram $2 n=$

13 20, 29, 30, 31, 35 e 40 (Figura 1A - I). As 20 amostras de E. viridans exibiram $2 n=20$,

14 29, 31, 40, 41 e 42 cromossomos (Figura 2 A - H). Várias amostras de ambas as

15 espécies exibiram cariótipos contendo cromossomos bem maiores que os demais, os

16 quais variaram de 3.16 a $4.74 \mu \mathrm{m}$ (Tabela 1). O comprimento total do lote diplóide foi

17 similar para os cariótipos com o mesmo número cromossômico independente da espécie

18 (Tabela 1).

19 A análise meiótica mostrou bivalentes apenas nas amostras com $2 n=20$ de 20 ambas as espécies (Figura 3A), $2 n=30$ de E. niederleinii (Figura 3B) de $2 n=42$ para 21 E. viridans (Figura 3C), em todos estes casos aquênios foram produzidos. As amostras 22 de E. niederleinii com $2 n=30$ coletadas em Sapopema e Porto União (veja a Tabela 1), 23 produziram poucas inflorescências e apenas 24 meiócitos puderam ser analisados. Estes 24 exibiram diferentes configurações, com $1^{\mathrm{IV}}+2^{\mathrm{III}}+9^{\mathrm{II}}+2^{\mathrm{I}}$ (Figura 3D) observados em 2511 células, $1^{\mathrm{IV}}+5^{\mathrm{III}}+4^{\mathrm{II}}+3^{\mathrm{I}}$ em quatro células, $2^{\mathrm{IV}}+2^{\mathrm{III}}+6^{\mathrm{II}}+3^{\mathrm{I}}$ em três células, $1^{\mathrm{IV}}$ 
$13^{\mathrm{III}}+7^{\mathrm{II}}+3^{\mathrm{I}}, 1^{\mathrm{IV}}+3^{\mathrm{III}}+6^{\mathrm{II}}+5^{\mathrm{I}}$ e $1^{\mathrm{IV}}+4^{\mathrm{III}}+4^{\mathrm{II}}+6^{\mathrm{I}}$, encontradas duas vezes para cada

2 configuração.

Múltiplas configurações também foram encontradas em amostras de E. viridans

$4 \operatorname{com} 2 n=31$ coletadas em Caçador/SC. Dos 15 meiócitos analisados, seis mostraram $7^{\text {III }}$

$5+3^{\mathrm{II}}+4^{\mathrm{I}}$ (Figura 3E), quatro mostraram $1^{\mathrm{VI}}+1^{\mathrm{IV}}+5^{\mathrm{III}}+2^{\mathrm{II}}+2^{\mathrm{I}}($ Figura $3 \mathrm{~F})$, duas $1^{\mathrm{VI}}+$

$64^{\mathrm{III}}+5^{\mathrm{II}}+3^{\mathrm{I}}$, duas $1^{\mathrm{V}}+5^{\mathrm{III}}+4^{\mathrm{II}}+3^{\mathrm{I}}$ e uma exibiu $1^{\mathrm{V}}+1^{\mathrm{IV}}+4^{\mathrm{III}}+3^{\mathrm{II}}+4^{\mathrm{I}}$. Além das

7 meioses irregulares, diferentes números cromossômicos foram encontrados na mitose

8 polínica. Das 56 células analisadas, 26 apresentaram $n=15$, com dois cromossomos

9 muito maiores que os demais (Figura $3 \mathrm{H}$ ), $15 \mathrm{com} n=17$ (Figura 3I), cinco com $n=$

1016 , quatro com $n=15$ e os números $n=13, n=14$ e $n=15$, foram verificados duas

11 vezes, e em todas estas células, um cromossomo muito maior que os demais foi

12 observado.

13 Para as amostras de E. viridans com $2 n=41$ coletadas em Balneário Pinhal e

14 Capivari do Sul, foram analisadas 63 meiócitos. Destes, 38 células exibiram $1^{\mathrm{III}}+19^{\mathrm{II}}$

15 (Figura 3G) e 25 células apresentaram $20^{\mathrm{II}}+1^{\mathrm{I}}$. Também foram encontrados diferentes

16 números cromossômicos na mitose polínica. Das 73 células analisadas, 34 exibiram $n=$

1722 (Figura 3J), 23 mostraram $n=21$ (Figura 3K), $n=20$ foi encontrada em 13 células e

18 apenas três exibiram $n=23$. Em todas estas células sempre dois cromossomos maiores

19 foram observados.

A hibridação in situ realizada com a sonda de DNAr 45S, mostrou de quatro a

21 seis sinais, sempre terminais nas duas espécies. Eleocharis niederleinii mostrou quatro

22 sinais nas amostras com $2 n=20$, 29 e 40 (Figuras 4A, B e G), e seis sítios nas amostras

23 com $2 n=30,31,35$ e 40 (Figuras 4C, D, E, H e I). Eleocharis viridans mostrou quatro

24 sítios nas mostras com $2 n=20,29$ e 41 (Figuras 5A, D e H), e seis sítios nas amostras 
1 com $2 n=29$, 31, 40, 41 e 42 (Figuras 5B, C, E, F e G). Variações nos tamanhos dos

2 sinais de hibridação foram encontradas em todas as amostras estudadas.

3

4

O dendrograma gerado pelo método de UPGMA agrupou as amostras em dois grandes grupos, considerando a similaridade de $80 \%$, contudo, houve uma mistura de espécies e localidades. O primeiro grupo foi composto por amostras do Paraná (várias amostras de E. niederleinii e apenas um indivíduo de E. viridans), Santa Catarina (E. niederleinii e E. viridans) e Rio Grande do Sul (somente E. viridans), e o segundo por amostras de Minas Gerais (E. niederleinii), Rio Grande do Sul (E. viridans) e Paraná (apenas um indivíduo de E. niederleinii). As amostras de uma mesma região foram agrupadas com alto coeficiente de similaridade (Figura 6). O dendrograma indica que em um mesmo estado as duas espécies podem ser encontradas, porém, em cada ponto coletado indivíduos de apenas uma espécie foram amostrados, com exceção de Pinhão/PR. A análise com o software Structure apontou a possível existência de sete grupos bem estruturados, sendo três de E. niederleinii e quatro de E. viridans (Figura. 6), indicando um possível isolamento para essas amostras. Para a realização da GISH os DNAs genômicos de E. niederleinii coletada em Alexandrita/MG e E. viridans coletada em Viamão/RS, ambas com $2 n=20$, foram utilizadas como sonda. A sonda obtida da amostra de E. niederleinii, foi hibridada nas amostras de E. niederleinii com $2 n=40$ coletadas em Pinhão/PR e São Luis do Purunã/PR, $2 n=30$ coletada em Tibagi/PR e na amostra com $2 n=35$ coletada em Conceição do Mato Dentro/MG. Em nenhum desses casos sinais de hibridação foram observados. Esta mesma sonda foi hibridada também em uma amostra de E. viridans com $2 n=41$ de Capivari do Sul/RS, e novamente nenhum sinal de hibridação foi visto. A mesma sonda foi hibridada na amostra de E. niederleinii com $2 n=40$ coletada em 
1 Alexandrita, neste caso sinais de hibridação foram observados em quase todos os

2 cromossomos (Figura 7A).

3 A sonda de E. viridans hibridou nas amostras de E. viridans com $2 n=42$

4 coletadas em Pinhão/PR e Lapa/SC, na amostra de $2 n=40$ de Pinhão e na amostra com

$52 n=29$ de Irani/SC, contudo o padrão de hibridação foi diferente entre elas. Na

6 amostra com $2 n=42$ de Pinhão, a sonda hibridou na região terminal de 13

7 cromossomos e em regiões intersticiais em dois (Figura 7B). Na amostra com $2 n=40$

8 de Pinhão, a maioria dos cromossomos exibiu sinais de hibridação (Figura 7E). Na

9 amostra de E. viridans com $2 n=42$, coletada na Lapa, sinais terminais foram

10 observados em 12 cromossomos e apenas 1 exibiu sinal intersticial (Figura 6C). Na

11 amostra com $2 n=29$, a maioria dos cromossomos foi detectada pela sonda, com sinais

12 terminais, intersticiais e em cromossomos inteiros (Figura 7D).

13 Esta sonda também foi hibridada em outras amostras de E. viridans coletadas

14 em Caçador/SC, Capivari do Sul/RS e Pinhão/PR, além das amostras de E. niederleinii

15 coletadas em Alexandrita, Tibagi/PR, São Luis do Purunã/PR e Biturama/PR. Em

16 nenhum destes casos foram observados sinais. Tanto para E. viridans quanto para E.

17 niederleinii, a sonda hibridou somente nas amostras cujas populações estavam

18 estruturadas, como pode ser observado no gráfico gerado pelo programa Structure

19 (Figura 6). Aparentemente as amostras que tiveram maior coeficiente de similaridade

20 com a amostra da sonda exibiram maior quantidade de sinais de hibridação. A única

21 diferente foi a amostra de E. viridans coletada na Lapa, a qual exibiu maior quantidade

22 de sinais do que esperado (Figura 7C), já que seu coeficiente de similaridade com o

23 genoma que originou a sonda foi cerca de 82\% (Figura 6).

25 Discussão 
De um modo geral, as alterações cromossômicas numéricas em Eleocharis são

2 provocadas por agmatoploidia, simploidia e principalmente por poliploidia, (Da Silva et

3 al. 2008a,b). Contudo, em subdivisões menores do gênero, como a Secção Eleocharis,

4 há um conjunto maior de espécies com cariótipos derivados por agmatoploidia e

5 simploidia, como as séries cromossômicas encontradas em E. uniglumis e E. palustris

6 (Bureš 1998 e Bureš et al. 2004). De acordo com Roalson e Friar (2000), esse grupo

7 pode ter uma origem para e polifilética. A série Tenuissimae estudada aqui também

8 pertence a esta secção e exibe uma grande variação nos números cromossômicos, como

$92 n=12$ e 20 em E. minima, $2 n=10$ em E. retroflexa (Da Silva et al. 2008a), bem como

10 os números $2 n=20,29,30,31,35,40,41$ e 42 encontrado aqui para E. niederleinii e

11 E. viridans. A série Tenuissimae pode ter origem parafilética (Roalson e Friar 2000 e

12 Yano et al. 2004), o que poderia explicar a grande diversidade morfológica das espécies

13 desse grupo (González-Elizondo e Tena-Flores 2000).

14 As amostras mais facilmente diferenciadas, seja para E. niederleinii ou E.

15 viridans, produziram inflorescências com flores férteis, aquênios viáveis, e cariótipos

16 com menores números cromossômicos, $2 n=20$ e 30 e meiose regular. Há também um

17 caso de E. viridans coletada em Viamão, RS, com $2 n=42$, com a presença de dois

18 cromossomos maiores em seu cariótipo, meiose regular e aquênios viáveis. Nas demais

19 amostras prevaleceram números cromossômicos variados, a ocorrência de um a quatro

20 cromossomos duas a três vezes maiores que os demais, derivados provavelmente de

21 fissão/fusão nestes cariótipos. Em alguns poucos casos houve a produção de espiguetas,

22 porém, a meiose foi irregular com formação de multivalentes e univalentes. Meiose

23 irregular em holocêntricos, associada a rearranjos cromossômicos, foi reportada para

24 Carex laevigata (Luceño e Castroviejo 1991). Além das evidências citogenéticas, a 
1 sobreposição de caracteres morfológicos associada à preferência por reprodução

2 assexuada, pode indicar uma origem híbrida para as duas espécies.

A FISH com a sonda de DNAr 45S revelou de 4 a 6 sítios terminais em todos

4 os diferentes cariótipos das duas espécies. Estes sítios aparecem nos cromossomos

5 maiores, porém não em todos eles, como observado nas amostras de E. niederleinii com

$62 n=40$ (São Luis do Purunã e Pinhão) e de E. viridans com $2 n=40$ (Lebon Regis e

7 Pinhão). Múltiplos sítios terminais de DNAr 45S também foram encontrados em

8 espécies de Rhynchospora e Eleocharis, sempre na posição terminal dos cromossomos

9 (Vanzela et al. 1998, Da Silva et al. 2008a, b), mesmo quando os cariótipos sofreram 10 rearranjos.

11 A reprodução assexuada foi observada em campo para todas as amostras 12 estudadas aqui, inclusive para aquelas com meiose regular que floresceram em 13 condições de casa de vegetação. Espécies prolíferas são encontradas em vários gêneros 14 de Cyperaceae, como em Cyperus, Eleocharis, Isolepis, Kyllinga e Schoenpplectus, e 15 para muitos desses casos, a reprodução prolífera foi induzida por condições de 16 ambientais estressantes. Isto foi observado em várias espécies na África do Sul 17 (Gordon-gray et al. 2008). Nossos resultados não permitem concluir se a condição 18 prolífera (reprodução assexuada) das amostras estudadas aqui aconteceu por influência 19 do ambiente, mas é possível que este evento ocorra devido a origem híbrida, como 20 sugerido por Chapman e Burke (2007).

21 As análises moleculares indicam uma similaridade superior a 95\% entre as 22 amostras de $2 n=20$ e 40 de E. niederleinii coletadas em Alexandrina, isto pode 23 explicar o padrão de marcas obtidas na GISH. Esta marcação parcial sugere a presença 24 de mais de um genoma na composição de $2 n=40$, ou seja, uma origem hibrida, para 25 esta amostra. O que poderia explicar também a ausência de inflorescências, quando 
1 comparada com a amostra de $2 n=20$, a qual exibiu inflorescências férteis e meiose

2 regular. Os resultados da GISH sugerem também mais de um genoma na composição

3 dos cariótipos de E. viridans coletadas em Pinhão, Viamão e Irani. Alopoliplóides

4 naturais são comuns (Soltis et al. 2003), e em alguns casos a GISH foi fundamental

5 para revelar este tipo de poliploidia (Galina et al. 2008; Bennett et al. 2004), como as

6 encontradas aqui.

7 Heilborn (citado em Davies 1956) considerou que a aparente falta de

8 alopoliplóide em Carex pode ser atribuída à degeneração de três núcleos dos quatro

9 formados ao final da meiose. Apesar desta relação não estar suficientemente esclarecida

10 (Hoshino e Shimizu 1986), híbridos interespecíficos foram detectados em Carex

11 (Luceño 1994).

12 Apesar da taxonomia identificar duas espécies (E. niederleinii e E. viridans), as 13 análises moleculares indicaram sete genomas estruturados com algumas sobreposições, 14 e as análise de hibridação genômica, mais de dois genomas. Essas informações nos 15 permitem sugerir a existência de isolamento, mesmo em situação simpátrica, sobretudo 16 para as amostras de Pinhão. Nossos resultados abrem uma excelente perspectiva para 17 estudos futuros envolvendo análises populacionais, de marcadores de herança 18 extragenômica, hibridação e poliploidia, e assim contribuir para o esclarecimento das 19 relações de parentesco dentro da série Tenuissimae.

\section{Agradecimentos}

22 Os autores agradecem as agências Brasileiras Fundação Araucária e CNPq pelo suporte 23 financeiro. 
2

Referências

Alves MV, Araújo AC, Prata AP, Vitta FA, Hefler SM, Trevisan R, Gil AB, Martins S, Thomas SWW. 2010. Diversity of Cyperaceae in Brazil Rodriguésia 60: 1-12

Bennett ST, Kenton AY, Bennett MD. 2004. Genomic in situ hybridization reveals the allopolyploid nature of Milium montianum (Gramineae) Chromosoma 101: $420-424$

Brasileiro ACM, Carneiro VTC 1998. Manual de Transformação Genética de Plantas. Brasileiro ACM, Carneiro VTC (eds) Brasília, Embrapa-SPI/Embrapa-Cenargen. 309 p.

Bureš P. 1998. A high polyploidy Eleocharis uniglumis S.L. (Cyperaceae) from central and southeastern Europe Folia Geobotanica 33: 429-439.

Bureš P, Rotreklová O, Stoneberg HSD, Pikner R. 2004. Cytogeographical survey of Eleocharis subser. Eleocharis in Europe 1. Eleocharis palustris. Folia Geobotanica 39: 235-257.

Chapman MA, Burke JM. 2007. Genetic divergente and hybrid speciation. Evolution 61: $1773-1780$

Da Silva CRM, González-Elizondo MS, Vanzela ALL. 2005. Reduction of chromosome number in Eleocharis subarticulata (Cyperaceae) by multiple translocations. Botanical Journal Linnean Society 149: 457-464. 
2 Da Silva CRM, González-Elizondo MS, Rego LNAA, Torezan JMD, Vanzela ALL. 2008a. Cytogenetical and cytotaxonomical analysis of some Brazilian species of Eleocharis. Australian Journal of Botany 56: 82-90.

Da Silva CRM, González-Elizondo MS, Vanzela ALL. 2008b. Chromosome Reduction in Eleocharis maculosa (Cyperaceae). Cytogenetic and Genome Research 122: 175-180.

Davies EW. 1956. Cytology, evolution and origin of the aneuploid series in the genus Carex. Hereditas 42: 349-365.

Falush D, Stephens M, Pritchard, JK. 2003. Inference of population structure using multilocus genotype data: Linked loci and correlated allele frequencies. Genetics 164: 1567-1587.

Galina P, Tatjana G, Jiming J, David SM. 2008. Allopolyploid speciation of the Mexican tetraploid potato species Solanum stoloniferum and S. hjertingii revealed by genomic in situ hybridization. Genome 51: 714-720

González-Elizondo MS, Peterson PM. 1997. A classification of and key to the supraspecific taxa in Eleocharis (Cyperaceae). Taxon 46: 433-449. 
1 González-Elizondo MS, Tena-Flores JA. 2000. Eleocharis (Cyperaceae) in the New

2 World. Pp. 637-641. In: Wilson, K. L. \& Morrison, D. A. (eds.). Monocots: Systematics 3 and Evolution. Melbourne: CSIRO.

4

5 Gordon-Gray KD, Baijnath H, Ward CJ, Wragg PD. 2008. Studies in Cyperaceae in southern Africa 42: Pseudo-vivipary in South African Cyperaceae. South African Journal of Botany 75: 167-171.

8

Heslop-Harrison JS, Schwarzacher T, Anamthawat-Jonsson K, Leitch AR, Shi M,

Leitch IJ. 1991. In situ hybridization with automated chromosome denaturation.

11 Technique 3: 106-109.

Hipp AL, Rothrock PE, Roalson EH. 2009. The evolution of chromosome arrangements in Carex (Cyperaceae). Botanical Review 75: 96-109.

Hoshino T, Shimizu T. 1986. Cytological studies on degenerative nuclei at pollen development of Carex ciliato-marginata. Journal Plant Research 99: 185-190.

Luceño M, Castroviejo S. 1991. Agmatoploidy in Carex laevigata (Cyperaceae): Fusion and fission of chromosomes as the mechanism of cytogenetic evolution in Iberian populations. Plant Systematic Evolution 177: 149-160.

Luceño M. 1994. Cytotaxonomic studies in Iberian, Balearic, North African, and Macaronesian species of Carex (Cyperaceae): II. Canadian Journal of Botany. 72: 587-596. 
2 Luceño M, Vanzela ALL, Guerra M. 1998. Cytotaxonomic studies in Brazilian

Pritchard JK, Stephens M, Donnelly P. 2000. Inference of population structure using multilocus genotype data. Genetics 155: 945-959.

Rambo B. 1959. Cyperaceae Riograndenses. Pesquisas 3: 354-453

Roalson EH, Friar EA. 2000. Infrageneric classification of Eleocharis (Cyperaceae) revisited: evidence from the Internal Transcribed Spacer (ITS) region of nuclear ribosomal DNA. Systematic Botany 25: 323-336.

Roalson EH. 2008. A synopsis of chromosome number variation in the Cyperaceae. Botanical Review 74: 209-393

Roalson EH, Hinchliff CE, Trevisan R, Da Silva CRM. (in press). Phylogenetic relationships in Eleocharis (Cyperaceae): C4 photosynthesis origins and patterns of diversification in the spikerushes. Systematic Botany 35: xxx-xxx.

Simpson DA. 1988. Some problems in Eleocharis. Notes on Brazilian Cyperaceae: III. Kew Bulletin 43: 127-134. 
1 Svenson HK. 1939. Monographic Studies in the Genus Eleocharis V. Rhodora 41: 1-

2

3

4 Soltis DE, Soltis PS, Tate JA. 2003. Advances in the study of polyploidy since Plant 5

6 110. speciation. New Phytologist 161: 173-191

Trevisan R, Boldrini II. 2008. O gênero Eleocharis R. Br. (Cyperaceae) no Rio Grande do Sul, Brasil. Revista Brasileira de Bociências 6: 7-67.

Vanzela ALL, Guerra M, Luceño M. 1996 Rhynchospora tenuis Link (Cyperaceae), a species with the lowest number of holocentric chromosomes $(n=2)$. Cytobios 88: 219-228.

Vanzela ALL, Cuadrado A, Jouve N, Luceño M, Guerra M. 1998. Multiple locations of the rDNA sites in holocentric chromosomes of Rhynchospora (Cyperaceae). Chromosome Research 6: 345-349.

Yano O, Katsuyama T, Tsubota H, Hoshino T. 2004. Molecular phylogeny of Japanese Eleocharis (Cyperaceae) based on ITS sequence data, and chromosomal evolution. Journal of Plant Research 117: 409-419. 


\section{Legendas}

2 Figura 1. Mitose em Eleocharis niederleinii, com diferentes números cromossômicos.

A) Amostra com $2 n=20$, com os cromossomos tamanhos próximos. B) Amostra com $2 n=29$. Note o núcleo arreticulado à esquerda. C) Amostra com $2 n=30$, com os cromossomos tamanhos próximos. D) Amostra com $2 n=30$. E) Amostra com $2 n=31$. F) Amostra com $2 n=35$, com os cromossomos tamanhos próximos. G - I) Amostras com $2 n=40$. Todas as setas apontam os cromossomos maiores. Barra $=10 \mu \mathrm{m}$

Figura 2. Mitose em Eleocharis viridans, com diferentes números cromossômicos. A) Amostra com $2 n=20$, com os cromossomos tamanhos próximos. B) Amostra $\operatorname{com} 2 n=29$. C) Amostra com $2 n=31$. D e E) Amostras com $2 n=40$. F e G) Amostras com $2 n=41$. G) Amostra com $2 n=42$. Todas as setas apontam os cromossomos maiores. Barra $=10 \mu \mathrm{m}$.

Figura 3. Diferentes fases da meiose para E. niederleinii e E. viridans. A) Metáfase I em E. niederleinii com $2 n=20$ e 10 bivalentes. B) Metáfase I em E. niederleinii com $2 n=30$ e 15 bivalentes. C) Metáfase I em E. viridans com $2 n$ = 42 e 21 bivalentes. Note os dois bivalentes maiores. D) Metáfase I em E. niederleinii com $2 n=30$ e com $1^{\mathrm{IV}}+2^{\mathrm{III}}+9^{\mathrm{II}}+2^{\mathrm{I}}$. E) Metáfase I em $E$. viridans $\operatorname{com} 2 n=31$ e $7^{\mathrm{III}}+3^{\mathrm{II}}+4^{\mathrm{I}}$. F) Metáfase I em E. viridans com $2 n=$ 31 e $1^{\mathrm{VI}}+1^{\mathrm{IV}}+5^{\mathrm{III}}+2^{\mathrm{II}}+2^{\mathrm{I}}$. G) Metáfase I em E. viridans com $2 n=41$ e $1^{\mathrm{III}}+$ $19^{\mathrm{II}}$. E m todas estas fotos: o "I" indica os univalentes, as setas apontas as associações multivalentes e as cabeças de seta apontam as associações trivalentes. H) Metáfase polínica em E. niederleinii com $n=15$, note os dois 
cromossomos maiores. I) Metáfase polínica em E. niederleinii com $n=17$, e todos os cromossomos com tamanhos próximos. J e K) Metáfase polínica em E. viridans com $n=22$ e $n=21$, respectivamente, as setas apontam os cromossomos maiores. Barra $=10 \mu \mathrm{m}$.

Figura 4. Hibridação in situ com a sonda de DNAr 45S em amostras de E. niederleinii. A) Amostra com $2 n=20$ e quatro sinais de hibridação. B) Amostra com $2 n=$ 29 e quatro sinais de hibridação. C) Amostra com $2 n=30$ e seis sinais de hibridação. D) Amostra com $2 n=30$ e seis sinais de hibridação. E) Amostra com $2 n=31$ e seis sinais de hibridação. F) Amostra com $2 n=40$ e quatro sinais de hibridação. Note que nas figuras D, E e F, os dois cromossomos maiores portam os sítios de DNAr 45S. G) Amostra com $2 n=40$ e quatro sinais de hibridação. H) Amostra com $2 n=35$ e seis sinais de hibridação. I) Amostra $\operatorname{com} 2 n=40$ e seis sinais de hibridação. A seta aponta o único cromossomo maior sem o sítio de DNAr 45S. Barra = 10 $\mu \mathrm{m}$.

Figura 5. Hibridação in situ com a sonda de DNAr 45S em amostras de E. viridans. A) Amostra com $2 n=20$ e quatro sinais de hibridação. B) Amostra com $2 n=29$ e seis sinais de hibridação. C) Amostra com $2 n=31$ e seis sinais de hibridação. D) Amostra com $2 n=40$ e quatro sinais de hibridação. E) Amostra com $2 n=$ 40 e seis sinais de hibridação. F) Amostra com $2 n=41$ e seis sinais de hibridação. Nas figuras D, E e F, as setas apontam os cromossomos maiores sem o sítio de DNAr 45S. G) Amostra com $2 n=42$ e seis sinais de hibridação. H) Amostra com $2 n=41$ e quatro sinais de hibridação. Barra $=10 \mu \mathrm{m}$. 
1 Figura 6. A) Mapa com os pontos de coleta. Os números representam as exsicatas de cada amostra. Os números vermelhos são de E. niederleinii os pretos são de $E$. viridans. Note que apenas em um ponto as duas espécies foram coletadas juntas (Pinhão). B) Dendrograma de similaridade genética obtido pelo coeficiente de Jaccard e pelo método UPGMA para as duas espécies.

Figura 7. Hibridação genômica in situ. A) Amostra de E. niederleinii com $2 n=40$ coletada em Alexandrita/MG, hibridada com a sonda da amostra de E. niederleinii $\operatorname{com} 2 n=20$ coletada no mesmo local. As fotos de B - E, são de diferentes amostras hibridadas com a sonda de E. viridans com $2 n=20$ coletada em Viamão/RS. B) Amostra de E. viridans com $2 n=42$ coletada em Pinhão/PR. C) Amostra de E. viridans com $2 n=42$ coletada na Lapa. D) Amostra de E. viridans com $2 n=29$ coletada em Irani/SC. Amostra de E. viridans com $2 n=40$ coletada em Pinhão/PR. Barra $=10 \mu \mathrm{m}$. 


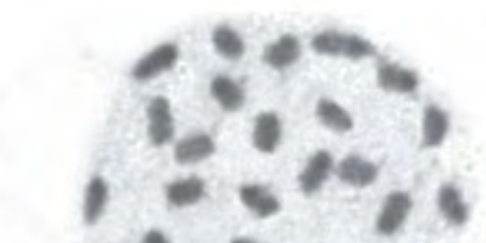

A

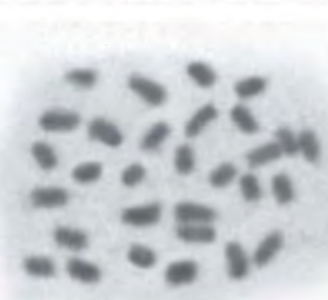

C

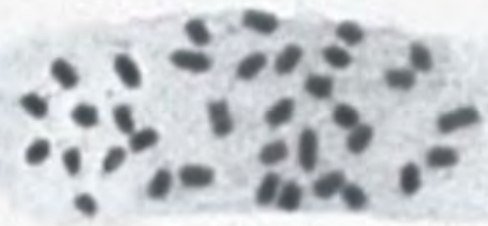

F

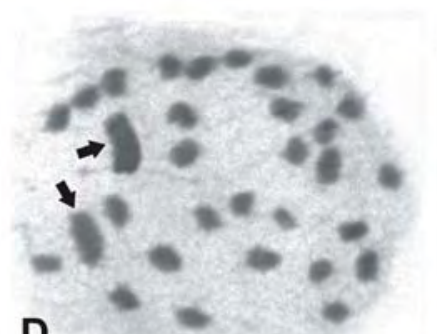

B

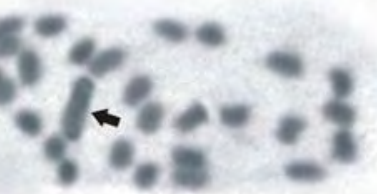

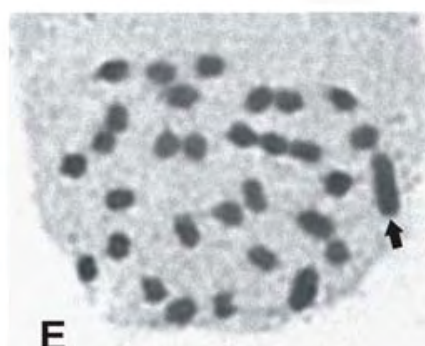

E

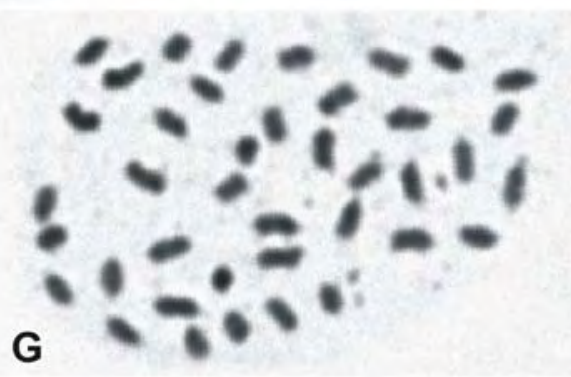

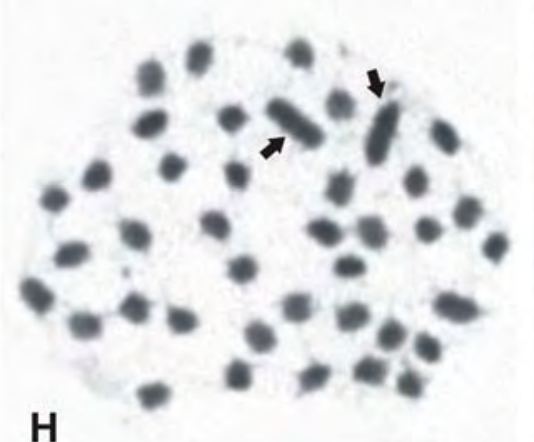

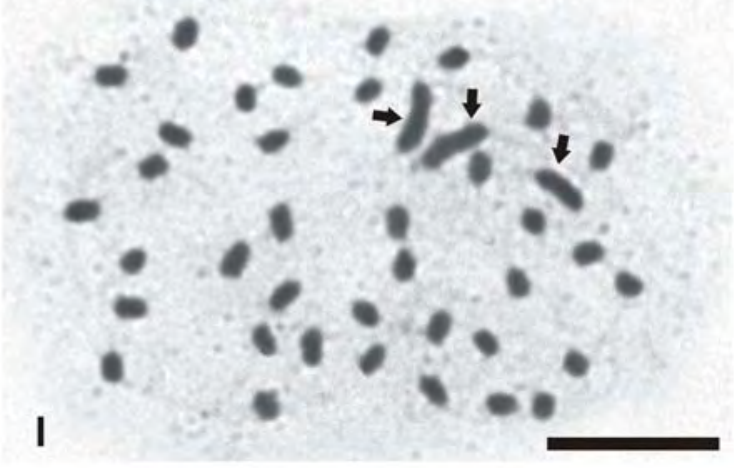



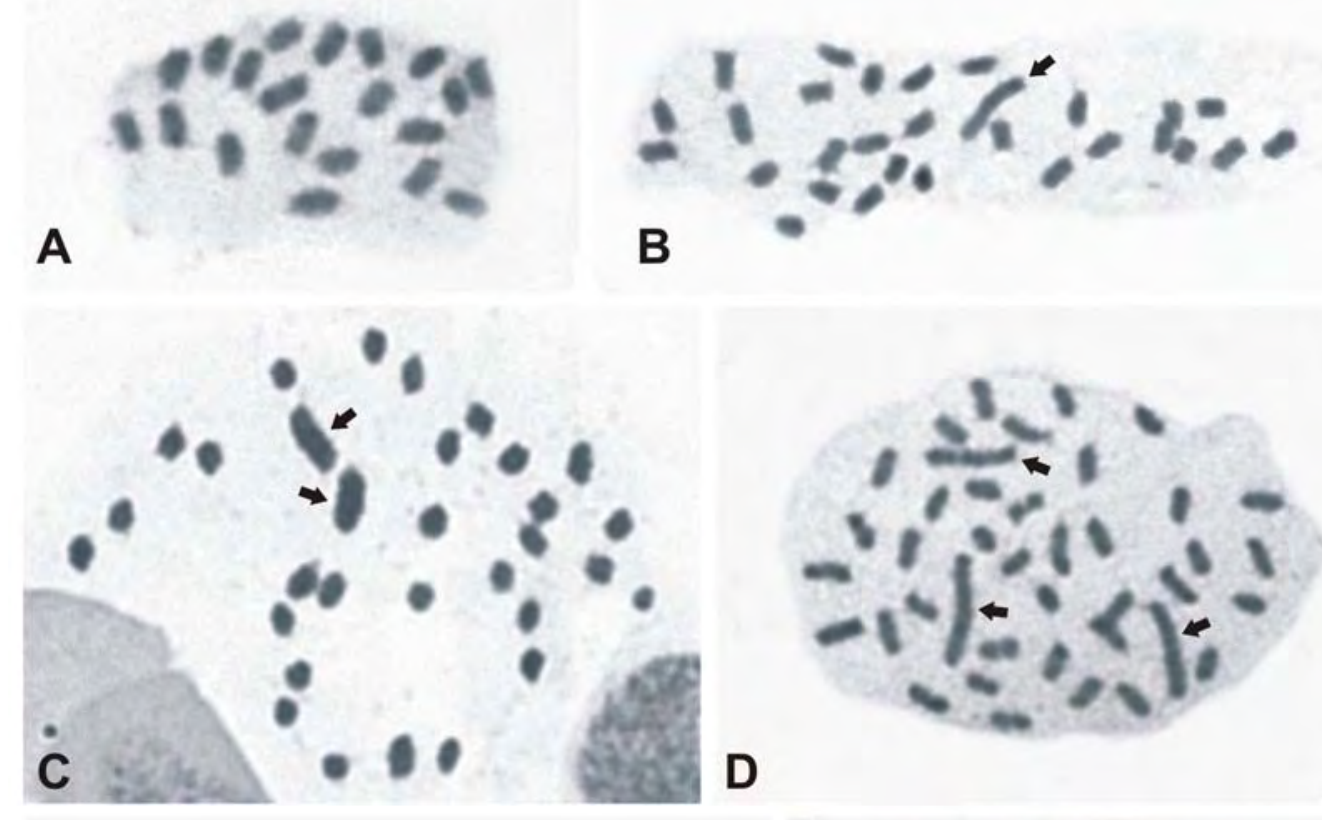

R.

E
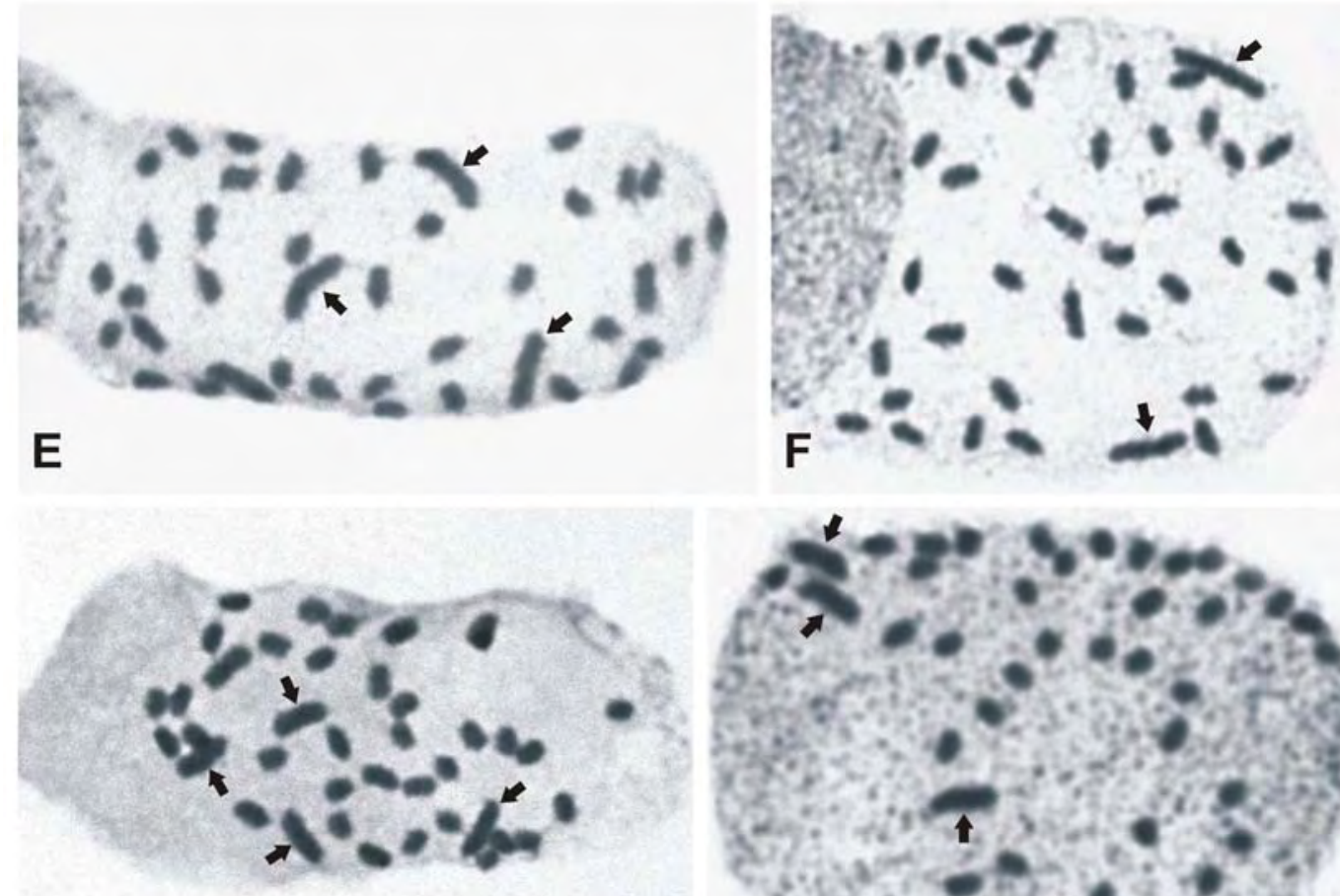

G

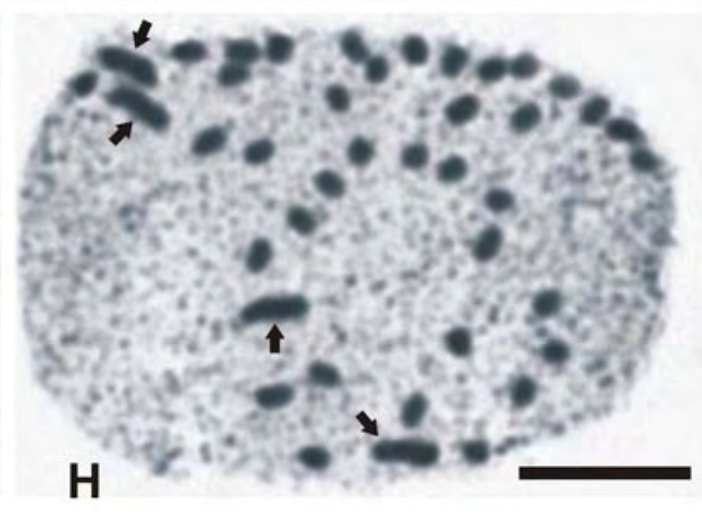

2

3

4

5

6 


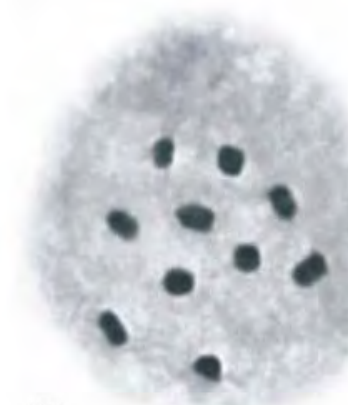

A

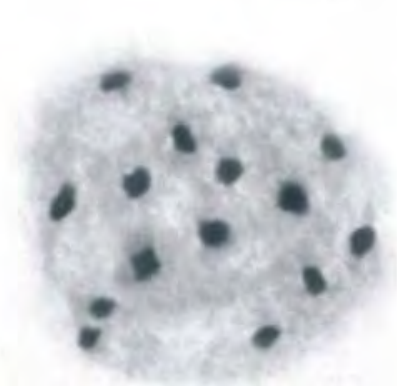

B

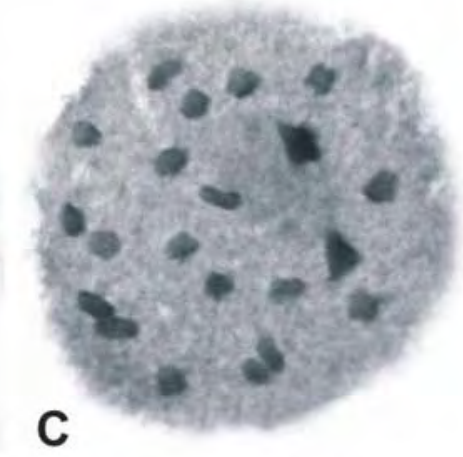

D
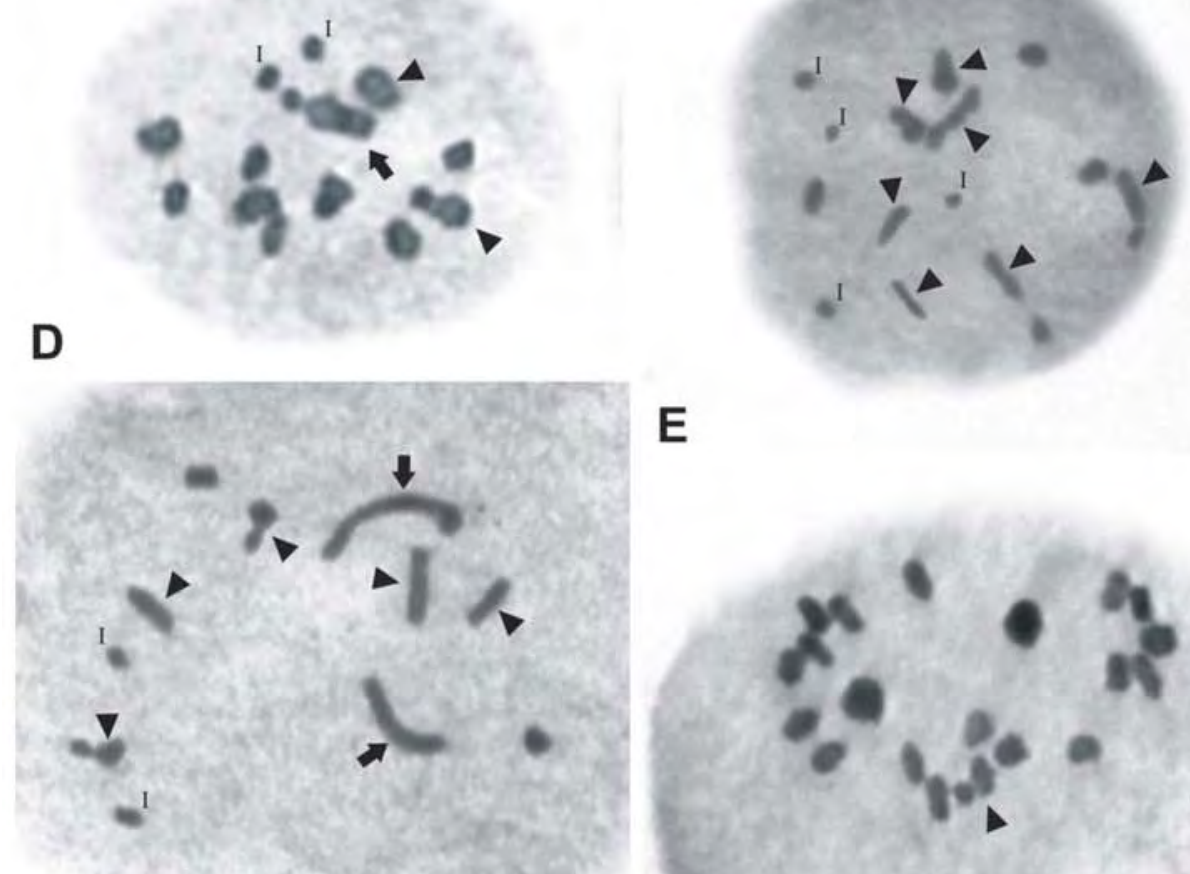

F

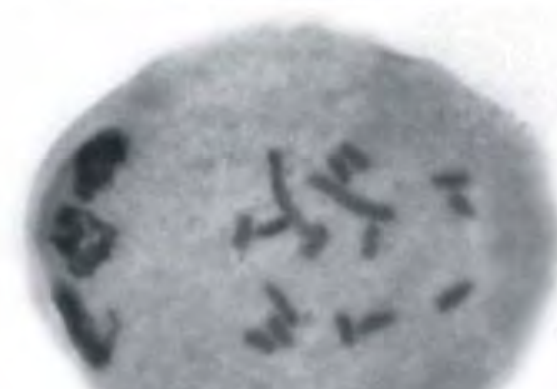

H

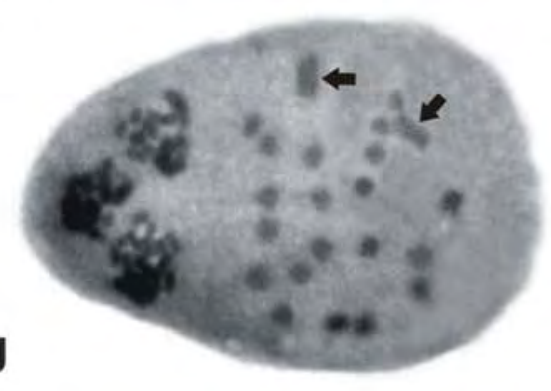

E

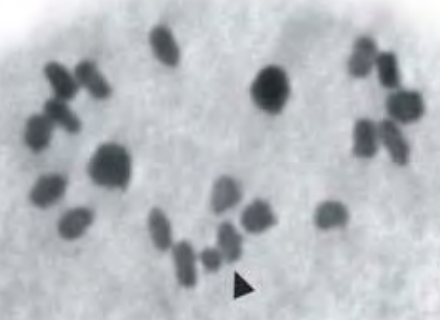

G
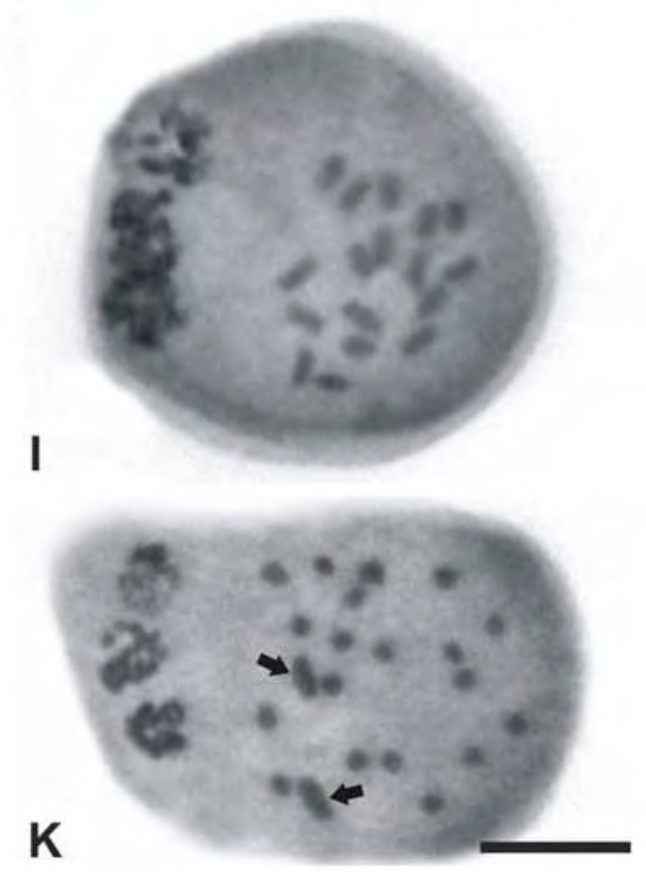

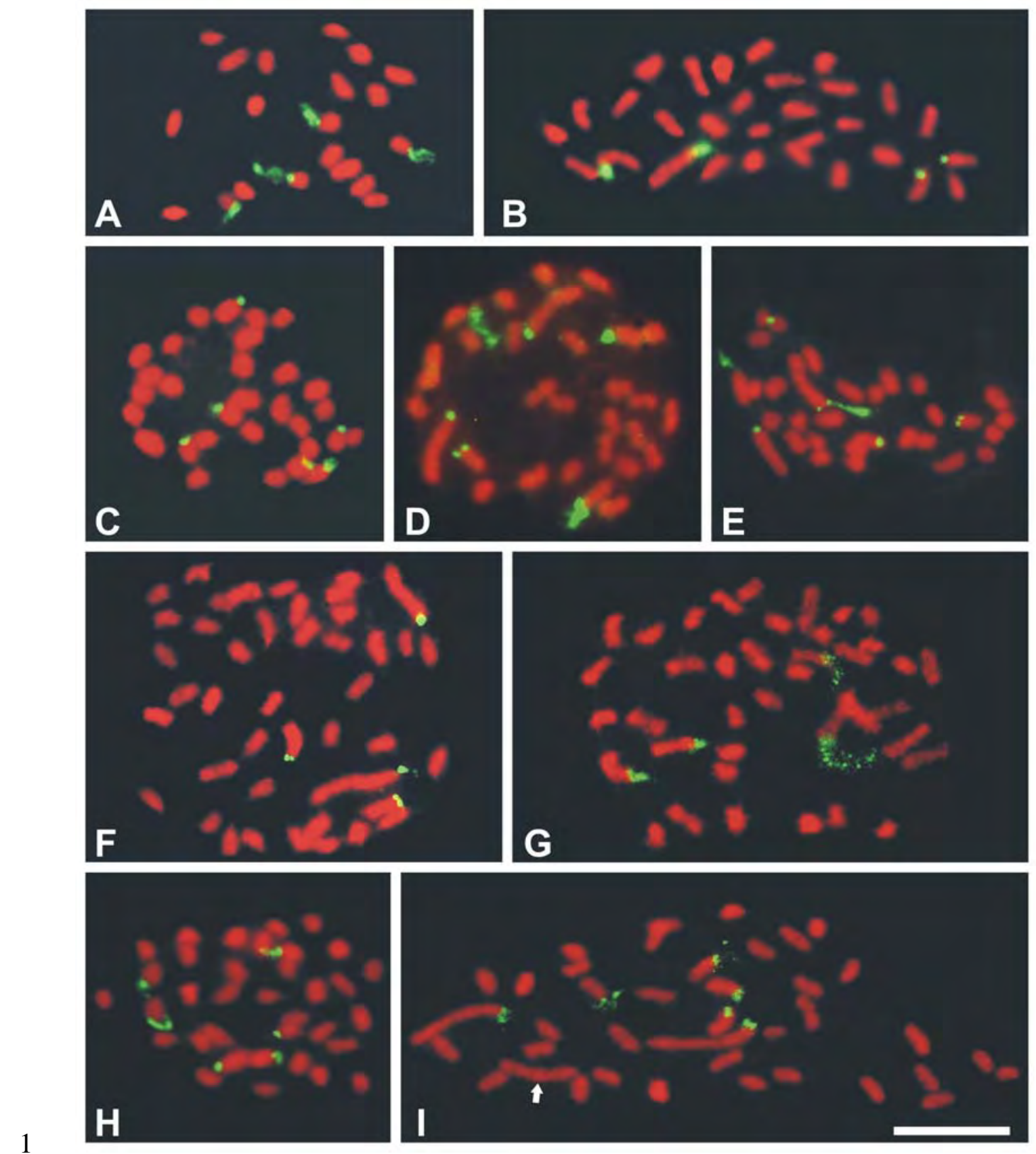

2

3

4

5

6

7

8 

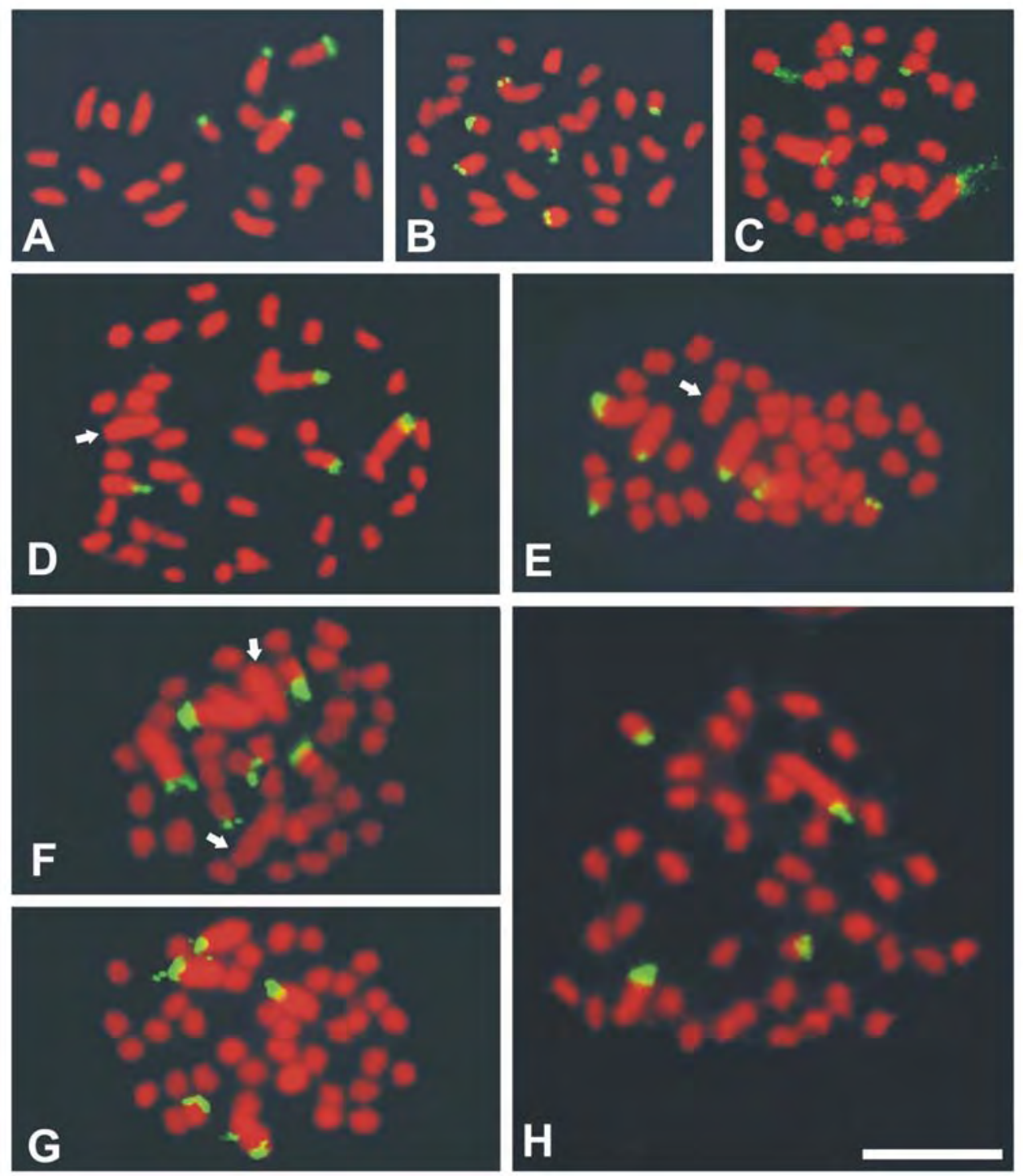

1

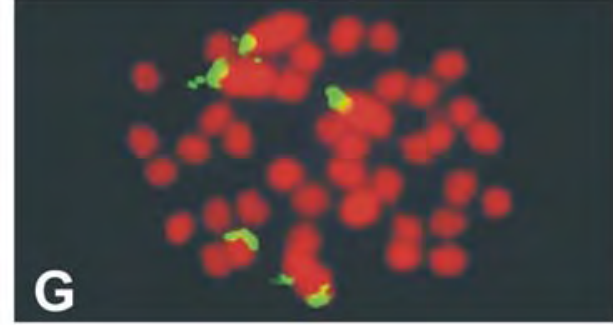

H

2

3

4

5

6

7

8

9

10 


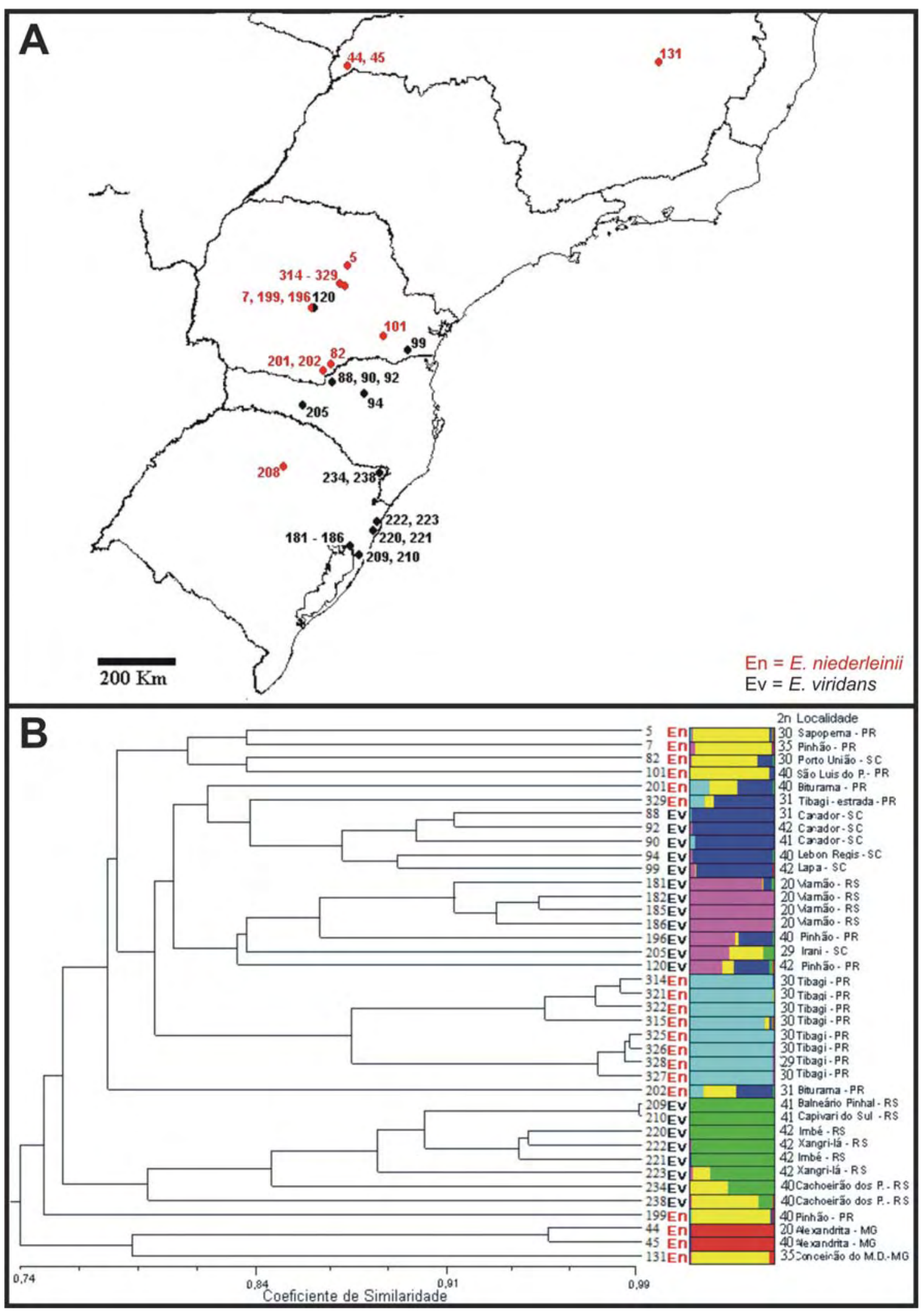



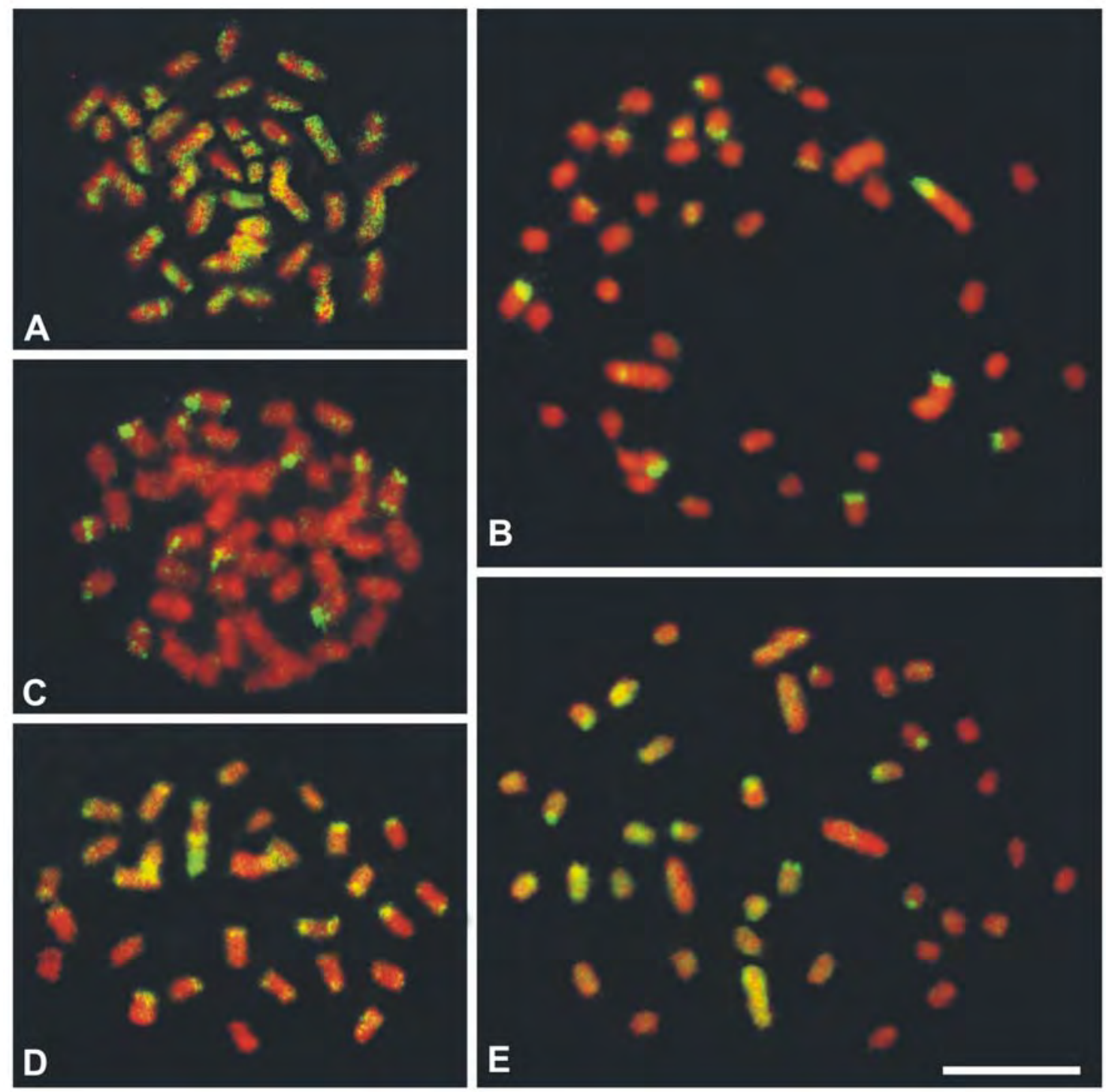

2

3

4

5

6

7

8

9

10 


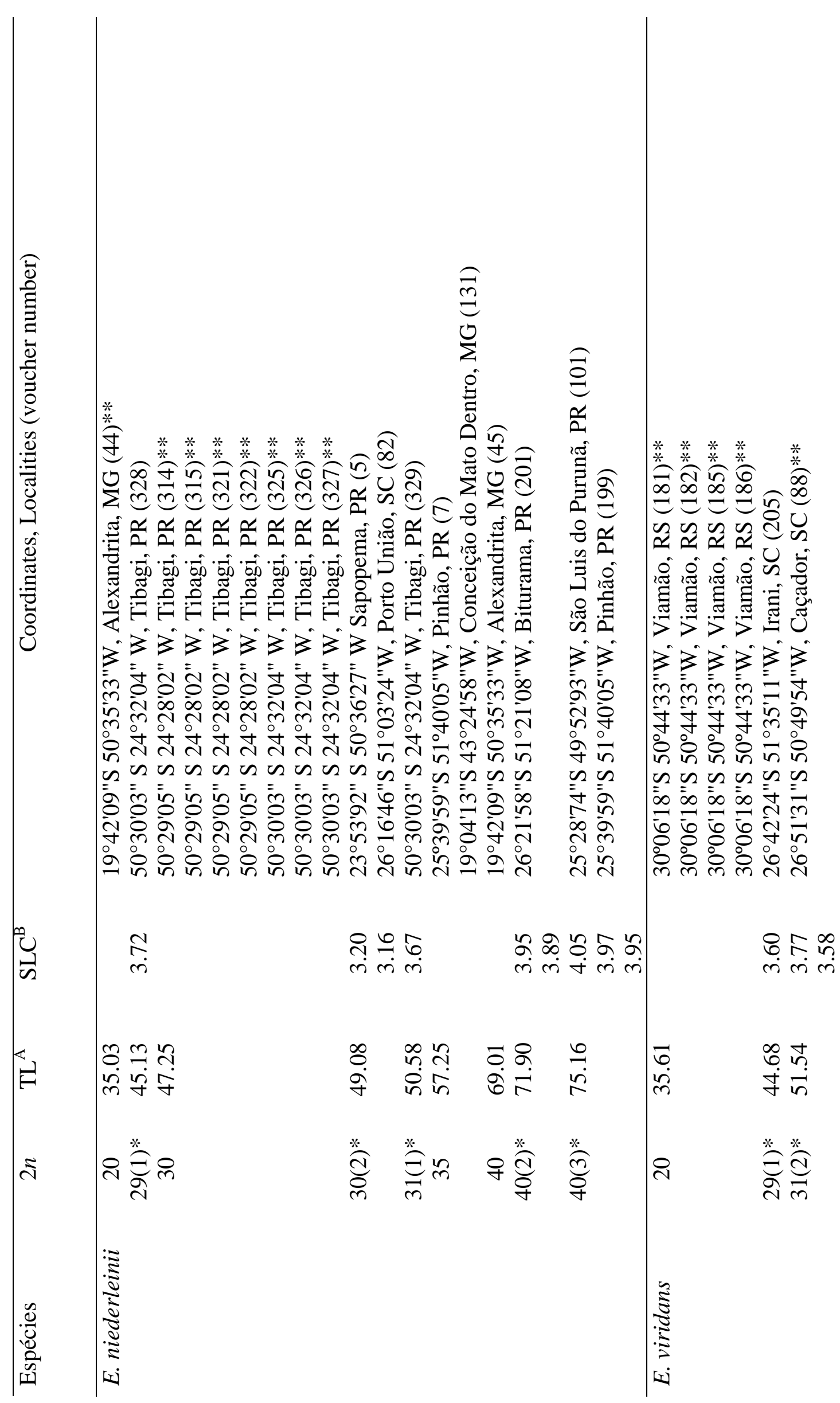




\section{Conclusões}




\section{Conclusões}

1) Nenhuma das 27 amostras estudadas exibiu constrição primária. Somente constrições nucleolares foram observadas em algumas metáfases para poucas espécies. Em E. sellowiana e E. maculosa a migração paralela dos cromossomos foi registrada. Para várias espécies, bivalentes formando a "estrutura em caixa” puderam ser observados. Assim, os dados resultantes deste trabalho confirmam a condição holocêntrica dos cromossomos neste gênero.

2) As medições cromossômicas feitas em 25 espécies mostram diminuição gradual no tamanho para a maioria delas. Com exceção, de E. maculosa, E. niederleinii, E. viridans e E. subarticulata, as quais exibiram cromossomos muito maiores em relação aos demais do seu cariótipo. Nas três primeiras espécies estes cromossomos grandes, surgiram por simploidia, e na última espécie, translocações múltiplas pode ser a causa da formação destes cromossomos.

3) Todas as espécies do subgênero Limnochloa estudadas exibiram $2 n=40$ ou mais cromossomos e estes foram menores que $1,4 \mu \mathrm{m}$.

4) Os números cromossômicos variaram de $2 n=6$ (E. subarticulata e E. maculosa) até $2 n$ = 60 (E. laeviglumis), com vários números intermediários, como 10, 20, 30 e 40, para a maioria das espécies. A alta frequência de espécies com números cromossômicos múltiplos de 5, concordam com trabalhos anteriores (Löve e Love 1957; Da Silva et al. 2008) que indica $x=5$ como o número básico do gênero. 
5) Apesar de E. maculosa, apresentar mais de um número cromossômico, decorrente de simploidia (fusão), e E. niederleinii e E. viridans, exibirem uma série cromossômicas causada provavelmente por poliploidia e rearranjos cromossômicos (fusão/fissão) associada a hibridação. A maioria da espécie (cerca de 80\%) foi poliplóide. Porém não foi possível concluir se ocorre há predominância de auto ou alopoliplóides.

6) Regiões heterocromáticas ricas em $\mathrm{CG}\left(\mathrm{DAPI}^{-} / \mathrm{CMA}^{+}\right)$foram localizadas apenas nas pontas dos cromossomos. Em várias espécies estas regiões estão associadas aos sítios de DNAr 45S.

7) Os sítios de DNAr 45S variaram em número entre as espécies, muitas vezes não acompanhando o nível de ploidia, como visto em E. flavescens $(2 n=10)$ com 10 sítios e em $E$. bonariensis $(2 n=20)$ com apenas dois. Mesmo quando os cariótipos sofreram rearranjos, como em E. maculosa com $2 n=10,8,7$ e 6, o número de sítios foram sempre quatro. Em todas as espécies analisadas os sítios foram terminais. Nas espécies que tiverem cariótipos mais simétricos, mais sítios de DNAr 45S foram encontrados. Estes dados nos permitem concluir que rearranjos cromossômicos (fusão, fissão e poliploidia) têm pouca influência na dispersão destes sítios, e que esta multiplicação de sítios pode ser resultado de amplificação seguido de dispersão pelas pontas dos cromossomos com tamanho próximos.

8) Os dados citológicos mostrados neste trabalho corroboram os de Yano et al. (2004) e Roalson e Friar (2000), os quais separam as espécies do subgênero Limnochloa dos demais subgêneros. Nossos resultados mostram que as espécies de Lmnochloa, possuem 
cariótipos com cromossomos numerosos e pequenos $(<1,4 \mu \mathrm{m})$. Os demais subgêneros possuem cromossomos maiores $(>1,5 \mu \mathrm{m})$. Assim sendo, a análise citogenética pode ser utilizada neste caso como um caráter micromorfológico muito útil na taxonomia.

\section{Referências}

Da Silva CRM, González-Elizondo MS, Rego LNAA, Torezan JMD, Vanzela ALL (2008). Cytogenetical and cytotaxonomical analysis of some Brazilian species of Eleocharis. Aust J Bot 56: 82-90.

Löve A, Löve D, Raymond M (1957). Cytotaxonomy of Carex section Capillares. Can. J. Bot. 35: 715-761.

Roalson EH, Friar EA (2000). Infrageneric classification of Eleocharis (Cyperaceae) revisited: evidence from the Internal Transcribed Spacer (ITS) region of nuclear ribosomal DNA. Syst Bot 25: 323-336.

Yano O, Katsuyama T, Tsubota H, Hoshino T (2004). Molecular phylogeny of Japanese Eleocharis (Cyperaceae) based on ITS sequence data, and chromosomal evolution. J Plant Res 117, 409-419. 